NUREG/CR-5972

ORNL/TM-12280

Effects of Nonstandard Heat

Treatment Temperatures on

Tensile and Charpy Impact

Properties of Carbon-Steel

Casting Repair Welds

Prepared by

R. K. Nanstad, G. M. Goodwin, M. J. Swindeman

RECEIVED

APR 221993

OSTI

Oak Ridge National Laboratory

Prepared for

U.S. Nuclear Regulatory Commission 


\section{AVAILABILITY NOTICE}

Availability of Reference Materials Cited in NRC Publications

Most documents clted in NRC publications will be avallable from one of the following sources:

1. The NRC Public Document Room, 2120 L Street, NW., Lower Level, Washington, DC 20555

2. The Superintendent of Documents, U.S. Government Printing Office, P.O. Box 37082, Washington, DC 20013-7082

3. The National Technical Information Service, Springfield, VA 22161

Although the listing that follows represents the majority of documents cited in NRC publications, it is not intended to be exhaustive.

Referenced documents available for inspection and copying for a fee from the NRC Public Document Room include NRC correspondence and internal NRC memoranda; NRC bulletins, circulars, information notices, inspection and investigation notices; licensee event reports; vendor reports and correspondence; Commission papers; and applicant and licensee documents and correspondence.

The following documents in the NUREG series are available for purchase from the GPO Sales Program: formal NRC staff and contractor reports, NRC-sponsored conference proceedings, international agreement reports, grant publications, and NRC booklets and brochures. Also available are regulatory guides, NRC regulations in the Code of Federal Regulations, and Nuclear Regulatory Commission Issuances.

Documents avallable from the National Technical Information Service include NUREG-series reports and technical reports prepared by other Federal agencies and reports prepared by the Atomic Energy Commission, forerunner agency to the Nuclear Regulatory Commission.

Documents available from public and special technical libraries include all open literature items, such as books, Journal articles, and transactions. Federal Register notices, Federal and State legislation, and congressional reports can usually be obtained from these libraries.

Documents such as theses, dissertations, foreign reports and translations, and non-NRC conference proceedings are available for purchase from the organization sponsoring the publication cited.

Single copies of NRC draft reports are available free, to the extent of supply, upon written request to the Office of Administration, Distribution and Mail Services Section, U.S. Nuclear Regulatory Commission, Washington, DC 20555.

Copies of industry codes and standards used in a substantive manner in the NRC regulatory process are maintained at the NRC Library, 7920 Norfolk Avenue, Bethesda, Maryland, for use by the public. Codes and standards are usually copyrighted and may be purchased from the originating organization or, if they are American National Standards, from the American National Standards Institute, 1430 Broadway, New York, NY 10018.

\section{DISCLAIMER NOTICE}

This report was prepared as an account of work sponsored by an agency of the United States Government. Neither the United States Government nor any agency thereof, or any of their employees, makes any warranty, expressed or implied, or assumes any legal liability of responsibility for any third party's use, or the results of such use, of any information, apparatus, product or process disclosed in this report, or represents that its use by such third party would not infringe privately owned rights. 


\section{DISCLAIMER}

This report was prepared as an account of work sponsored by an agency of the United States Government. Neither the United States Government nor any agency Thereof, nor any of their employees, makes any warranty, express or implied, or assumes any legal liability or responsibility for the accuracy, completeness, or usefulness of any information, apparatus, product, or process disclosed, or represents that its use would not infringe privately owned rights. Reference herein to any specific commercial product, process, or service by trade name, trademark, manufacturer, or otherwise does not necessarily constitute or imply its endorsement, recommendation, or favoring by the United States Government or any agency thereof. The views and opinions of authors expressed herein do not necessarily state or reflect those of the United States Government or any agency thereof. 


\section{DISCLAIMER}

Portions of this document may be illegible in electronic image products. Images are produced from the best available original document. 


\section{Effects of Nonstandard Heat}

Treatment Temperatures on

Tensile and Charpy Impact

Properties of Carbon-Steel

Casting Repair Welds

Manuscript Completed: December 1992

Date Published: April 1993

Prepared by

R. K. Nanstad, G. M. Goodwin, M. J. Swindeman

Oak Ridge National Laboratory

Operated by Martin Marietta Energy Systems, Inc.

Oak Ridge National Laboratory

Oak Ridge, TN 37831-6285

\section{Prepared for}

Division of Engineering

Office of Nuclear Regulatory Research

U.S. Nuclear Regulatory Commission

Washington, DC 20555

NRC FIN B0103

Under Contract No. DE-AC05-840R21400 



\section{Abstract}

Carbon steel castings are used for a number of different components in nuclear power plants, including valve bodies and bonnets.

Components are often repaired by welding processes, and both welded components and the repair welds are subjected to a variety of postweld heat treatments (PWHT) with temperatures as high as $899^{\circ} \mathrm{C}\left(1650^{\circ} \mathrm{F}\right)$, well above the normal 593 to $677^{\circ} \mathrm{C}\left(1100\right.$ to $\left.1250^{\circ} \mathrm{F}\right)$ temperature range. The temperatures noted are above the $\mathrm{A} 1$ transformation temperature for the materials used for these components. A test program was conducted to investigate the potential effects of such "nonstandard" PWHTs on mechanical properties of carbon steel casting welds. Four weldments were fabricated, two each with the shielded-metal-arc (SMA) and flux-cored-arc (FCA) processes, with a high-carbon and low-carbon filler metal in each case. All four welds were sectioned and given simulated PWHTs at temperatures from
621 to $899^{\circ} \mathrm{C}\left(1150\right.$ to $\left.1650^{\circ} \mathrm{F}\right)$ in increments of $56^{\circ} \mathrm{C}\left(100^{\circ} \mathrm{F}\right)$ and for times of $5,10,20$, and $40 \mathrm{~h}$ at each temperature. Hardness, tensile, and Charpy V-notch (CVN) impact tests were conducted for the as-welded and heat-treated conditions. Results were plotted versus a time-temperature relationship (tempering parameter) to enable a more direct comparison of the effects of the various PWHT conditions. Heat treatments at 621 and $677^{\circ} \mathrm{C}(1150$ and $1250^{\circ} \mathrm{F}$ ) gave results amenable to prediction, and regression analyses are presented for those conditions. Heat treatments at 732 to $899^{\circ} \mathrm{C}\left(1350\right.$ to $\left.1650^{\circ} \mathrm{F}\right)$, however, resulted in substantial changes in mechanical properties of these SMA and FCA welds, with the changes not amenable to prediction and highly dependent on the weld metal. Heat treatments in that temperature range should not be applied to these materials without prior qualification for the intended use. 
. 


\section{Contents}

Page

Abstract $\ldots \ldots \ldots \ldots \ldots \ldots \ldots \ldots \ldots \ldots \ldots \ldots \ldots \ldots \ldots \ldots \ldots \ldots \ldots$

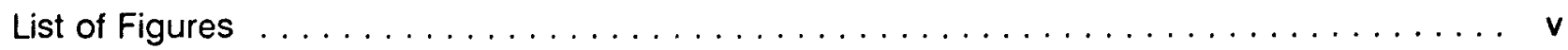

List of Tables $\ldots \ldots \ldots \ldots \ldots \ldots \ldots \ldots \ldots \ldots \ldots \ldots \ldots \ldots \ldots \ldots \ldots$ ix

Acknowledgments $\ldots \ldots \ldots \ldots \ldots \ldots \ldots \ldots \ldots \ldots \ldots \ldots \ldots \ldots \ldots$

Introduction $\ldots \ldots \ldots \ldots \ldots \ldots \ldots \ldots \ldots \ldots \ldots \ldots \ldots \ldots \ldots \ldots \ldots \ldots$

Materials, Fabrication, and Heat Treatment $\ldots \ldots \ldots \ldots \ldots \ldots \ldots \ldots \ldots \ldots$

Testing and Analysis Procedures $\ldots \ldots \ldots \ldots \ldots \ldots \ldots \ldots \ldots \ldots \ldots$

Results and Discussion $\ldots \ldots \ldots \ldots \ldots \ldots \ldots \ldots \ldots \ldots \ldots \ldots \ldots$

Hardness Results $\ldots \ldots \ldots \ldots \ldots \ldots \ldots \ldots \ldots \ldots \ldots \ldots \ldots \ldots$

Tensile Results $\ldots \ldots \ldots \ldots \ldots \ldots \ldots \ldots \ldots \ldots \ldots \ldots \ldots \ldots \ldots \ldots$

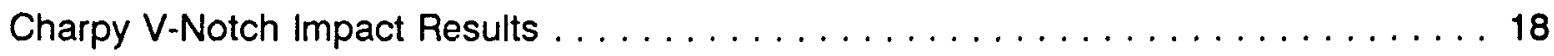

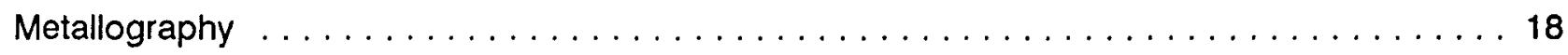

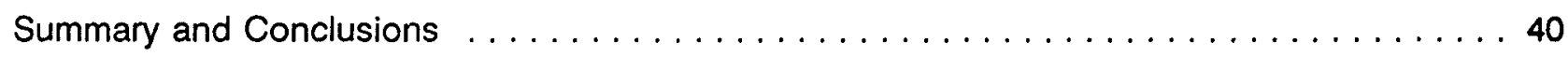

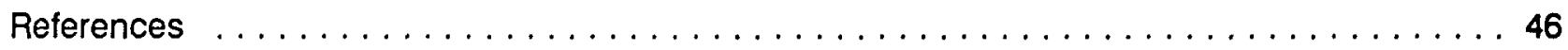

Appendix A - Hardness Data for Welds 1 Through $4 \ldots \ldots \ldots \ldots \ldots \ldots \ldots \ldots$

Appendix B - Tensile Data for Welds 1 Through $4 \ldots \ldots \ldots \ldots \ldots \ldots \ldots$

Appendix C - Charpy Impact Data for Welds 1 Through $4 \ldots \ldots \ldots \ldots \ldots \ldots \ldots$

Figures

1 Schematic drawing showing the locations for machining of Charpy impact and tensile test specimen blanks in welds 1 through $4 \ldots \ldots \ldots \ldots \ldots \ldots \ldots$

2 Drawings of (a) tensile and (b) CVN impact test specimens for welds 1

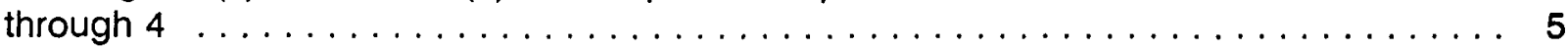

3 Plot of hardness (HRB) versus the TP, $T^{*}(15+\log t)$, for weld 1 , a low-carbon SMA weld. The equation shown is the result of a linear regression to the data at PWHT temperatures of $677^{\circ} \mathrm{C}\left(1250^{\circ} \mathrm{F}\right)$ and lower, while the solid line shows the resulting fit 
4 Plot of hardness (HRB) versus the TP, $T^{\star}(15+\log t)$, for weld 2 , a high-carbon SMA weld. The equation shown is the result of a linear regression to the data at PWHT temperatures of $677^{\circ} \mathrm{C}\left(1250^{\circ} \mathrm{F}\right)$ and lower, while the solid line shows the

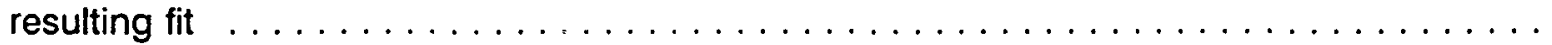

5 Plot of hardness (HRB) versus the TP, $T^{\star}(15+\log t)$, for weld 3 , a high-carbon FCA weld. The equation shown is the result of a linear regression to the data at PWHT temperatures of $677^{\circ} \mathrm{C}\left(1250^{\circ} \mathrm{F}\right)$ and lower, while the solid line shows the

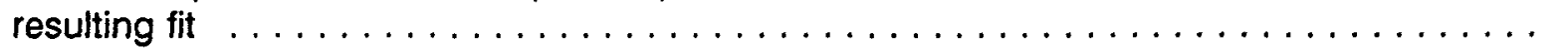

6 Plot of hardness (HRB) versus the TP, $T^{\star}(15+\log t)$, for weld 4 , a low-carbon FCA weld. The equation shown is the result of a linear regression to the data at PWHT temperatures of $677^{\circ} \mathrm{C}\left(1250^{\circ} \mathrm{F}\right)$ and lower, while the solid line shows the

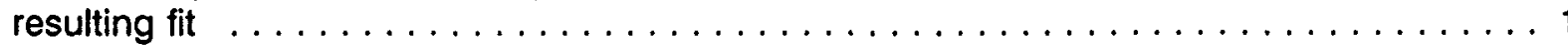

7 Comparison of linear regression curves to hardness (HRB) results versus the TP, $T^{*}(15+\log t)$, for welds 1 through 4

8 (a) Yield strength and (b) ultimate strength versus the TP, $T^{*}(15+\log t)$, for weld 1 , a low-carbon SMA weld. The equation shown is the result of a linear regression to the data at PWHT temperatures of $677^{\circ} \mathrm{C}\left(1250^{\circ} \mathrm{F}\right)$ and lower, while the solid line shows the resulting fit $\ldots \ldots \ldots \ldots \ldots \ldots \ldots \ldots \ldots \ldots \ldots \ldots \ldots$

9 (a) Yield strength and (b) ultimate strength versus the TP, $T^{*}(15+\log t)$, for weld 2 , a high-carbon SMA weld. The equation shown is the result of a linear regression to the data at PWHT temperatures of $677^{\circ} \mathrm{C}\left(1250^{\circ} \mathrm{F}\right)$ and lower, while the solid line shows the resulting fit

10 (a) Yield strength and (b) ultimate strength versus the TP, $T^{\star}(15+\log t)$, for weld 3, a high-carbon FCA weld. The equation shown is the result of a linear regression to the data at PWHT temperatures of $677^{\circ} \mathrm{C}\left(1250^{\circ} \mathrm{F}\right)$ and lower, while the solid line

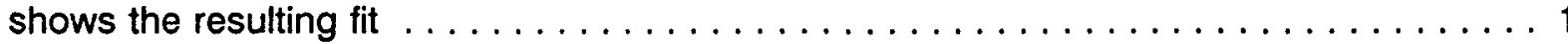

11 (a) Yield strength and $(b)$ ultimate strength versus the TP, $T^{\star}(15+\log t)$, for weld 4, a low-carbon FCA weld. The equation shown is the result of a linear regression to the data at PWHT temperatures of $677^{\circ} \mathrm{C}\left(1250^{\circ} \mathrm{F}\right)$ and lower, while the solid line shows the resulting fit

12 Comparison of linear regression curves to yield strength results versus the TP,

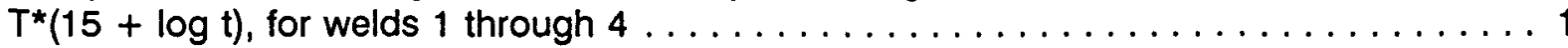

13 Comparison of linear regression curves to ultimate strength results versus the TP, $T^{\star}(15+\log t)$, for welds 1 through 4

14 CVN energy versus test temperature for weld 1, a low-carbon SMA weld in the as-welded condition. The solid curve is the resulting fit of the data to a hyperbolic tangent function

15 CVN energy versus test temperature for weld 2, a high-carbon SMA weld in the as-welded condition. The solid curve is the resulting fit of the data to a hyperbolic tangent function 
16 CVN energy versus test temperature for weld 3, a high-carbon FCA weld in the as-welded condition. The solid curve is the resulting fit of the data to a hyperbolic tangent function

17 CVN energy versus test temperature for weld 4, a low-carbon FCA weld in the as-welded condition. The solid curve is the resulting fit of the data to a hyperbolic tangent function

18 Comparison of hyperbolic tangent curve fits to CVN energy versus test temperature data for welds 1 through 4 in the as-welded condition

19 Effects of PWHT on CVN impact behavior showing (a) $T_{0},(b) T_{27 J},(c) T_{68 \text {, }}$, and (d) USE versus the TP, $T^{\star}(15+\log t)$, for weld 1 , a low-carbon SMA weld. The equation shown in $(d)$ is the result of a linear regression to the USE data at PWHT temperatures of $677^{\circ} \mathrm{C}\left(1250^{\circ} \mathrm{F}\right)$ and lower, while the solid line shows the

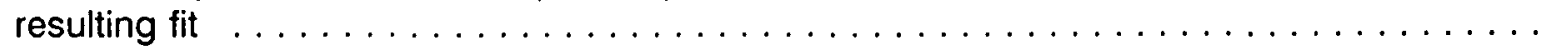

20 Effects of PWHT on CVN impact behavior showing (a) $T_{0},(b) T_{27 \jmath},(c) T_{68 \text {, }}$, and (d) USE versus the TP, $T^{\star}(15+\log t)$, for weld 2, a high-carbon SMA weld. The equation shown in $(d)$ is the result of a linear regression to the USE data at PWHT temperatures of $677^{\circ} \mathrm{C}\left(1250^{\circ} \mathrm{F}\right)$ and lower, while the solid line shows the resulting fit

21 Effects of PWHT on CVN impact behavior showing (a) $T_{0},(b) \pi_{27}$, and (c) USE versus the $T P, T^{\star}(15+\log t)$, for weld 3 , a high-carbon FCA weld. The equation shown in $(c)$ is the result of a linear regression to the USE data at PWHT temperatures of $677^{\circ} \mathrm{C}\left(1250^{\circ} \mathrm{F}\right)$ and lower, while the solid line shows the resulting fit $\ldots \ldots \ldots \ldots \ldots \ldots \ldots \ldots \ldots \ldots \ldots \ldots \ldots \ldots \ldots \ldots$

22 Effects of PWHT on CVN impact behavior showing (a) $T_{0},(b) T_{27 J},(c) T_{68,}$, and (d) USE versus the TP, $T^{\star}(15+\log t)$, for weld 4, a low-carbon FCA weld. The equation shown in $(d)$ is the result of a linear regression to the USE data at PWHT temperatures of $677^{\circ} \mathrm{C}\left(1250^{\circ} \mathrm{F}\right)$ and lower, while the solid line shows the resulting fit

23 Comparison of linear regression curves to USE results versus the TP, $T^{\star}(15+\log t)$, for welds 1 through 4

24 Micrographs of (a) through (d), welds 1 through 4, respectively, in the as-welded condition

25 Micrographs of (a) welds 1 and $(b) 3$, heat-treated at $1350^{\circ} \mathrm{F}$ for $5 \mathrm{~h}$. Transformation is essentially complete, and longer times do not seem to coarsen the transformed structure, as shown in (c) for weld 3 heat treated for $40 \mathrm{~h}$

26 Micrographs of welds 1 through 4 , heat treated at $1650^{\circ} \mathrm{F}$. Additional time at temperature for weld 1 at (a) $5 \mathrm{~h}$ and $(b) 40 \mathrm{~h}$, results in coarsening of the structure. Welds 2,3 , and 4 at $1650^{\circ} \mathrm{F}$ for $40 \mathrm{~h}$ are shown in $(c),(d)$, and (e), respectively 



\section{Tables}

Page

1 Summary of specifications and chemical compositions for welds 1 through $4 \ldots \ldots$

2 Numbering scheme used to identity sections from which test specimens were

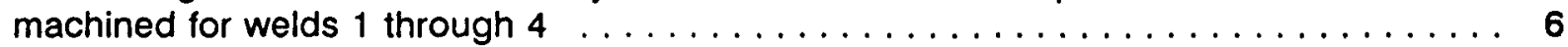

3 Summary of Charpy impact analysis for weld 1, low-carbon SMA weld . . . . . . . . . 20

4 Summary of Charpy impact analysis for weld 2 , high-carbon SMA weld . . . . . . . 21

5 Summary of Charpy impact analysis for weld 3 , high-carbon FCA weld . . . . . . . . . 22

6 Summary of Charpy impact analysis for weld 4 , low-carbon FCA weld . . . . . . . . 23

A-1 Hardness data for weld 1 , low-carbon SMA $\ldots \ldots \ldots \ldots \ldots \ldots \ldots \ldots \ldots \ldots$

A-2 Hardness data for weld 2 , high-carbon SMA $\ldots \ldots \ldots \ldots \ldots \ldots \ldots \ldots \ldots$

A-3 Hardness data for weld 3 , high-carbon FCA $\ldots \ldots \ldots \ldots \ldots \ldots \ldots \ldots \ldots \ldots$

A-4 Hardness data for weld 4 , low-carbon FCA $\ldots \ldots \ldots \ldots \ldots \ldots \ldots \ldots \ldots$

B-1 Tensile data for weld 1 , low-carbon SMA $\ldots \ldots \ldots \ldots \ldots \ldots \ldots \ldots \ldots \ldots \ldots$

B-2 Tensile data for weld 2 , high-carbon SMA $\ldots \ldots \ldots \ldots \ldots \ldots \ldots \ldots \ldots \ldots$

B-3 Tensile data for weld 3 , high-carbon FCA $\ldots \ldots \ldots \ldots \ldots \ldots \ldots \ldots \ldots$

B-4 Tensile data for weld 4 , low-carbon FCA $\ldots \ldots \ldots \ldots \ldots \ldots \ldots \ldots \ldots$

C-1 Charpy impact data for weld 1 , low-carbon SMA $\ldots \ldots \ldots \ldots \ldots \ldots \ldots \ldots \ldots$

C-2 Charpy impact data for weld 2 , high-carbon SMA $\ldots \ldots \ldots \ldots \ldots \ldots \ldots \ldots \ldots$

C-3 Charpy impact data for weld 3 , high-carbon FCA . . . . . . . . . . . . . . C-20

C-4 Charpy impact data for weld 4 , low-carbon FCA $\ldots \ldots \ldots \ldots \ldots \ldots \ldots \ldots \ldots$. . . . . . . . 



\section{Acknowledgments}

The authors wish to acknowledge Dennis Swaney, Jeft McNabb, and Vernon Houchin for weldment fabrication; Eric Manneschmidt, John Henry, and Ned Asuncion for tensile and Charpy impact

testing; Hugh Longmire for metallography; Julia Bishop for manuscript preparation; David Alexander and Jim King for manuscript review; Kathy Spence for editing; and Donna Balltrip for preparation of the final document. We also acknowledge financial support from the Materials Engineering Branch, U.S. Nuclear Regulatory Commission, and, specifically, E. O. Woolridge, Technical Monitor for the Additional Requirements for Materials Program. 


\title{
Effects of Nonstandard Heat-Treatment Temperatures \\ on Tensile and Charpy Impact Properties of Carbon-Steel Casting Repair Welds ${ }^{\star}$
}

\author{
R. K. Nanstad, G. M. Goodwin, and M. J. Swindemant
}

\section{Introduction}

\begin{abstract}
Carbon steel castings are used for a number of different components in nuclear power plants, including valve bodies and bonnets. As a result of reviews of component manufacturing procedures by Region 1 of the U.S. Nuclear Regulatory Commission, it was noted that components are often repaired by welding processes and that both welded components and the repair welds are subjected to a variety of postweld heat treatments (PWHT) above the 593 to $677^{\circ} \mathrm{C}\left(1100\right.$ to $\left.1250^{\circ} \mathrm{F}\right)$ temperature range. $¥$ In some cases, the repairs have been applied to components in the as-cast condition, followed by normalizing at $899^{\circ} \mathrm{C}\left(1650^{\circ} \mathrm{F}\right)$. In other cases, the previously heat-treated components are welded and then given a PWHT at $732^{\circ} \mathrm{C}\left(1350^{\circ} \mathrm{F}\right)$. The temperatures noted are above the $A 1$ transformation temperature for the materials used for these components. Thus, a concern was expressed that such practices may cause undesirable changes in mechanical properties of the weld metals used to affect repairs. Therefore, a test program was conducted to investigate the potential effects of such "nonstandard" PWHTs on mechanical properties of carbon-steel casting welds.
\end{abstract}

\footnotetext{
"Research was sponsored by the Office of Nuclear Regulatory Research, Division of Engineering, U.S. Nuclear Regulatory Commission, under Interagency Agreement DOE 1886-8010-3B with the U.S. Department of Energy under contract DE-AC05-84OR21400 with Martin Marietta Energy Systems, Inc.

†Summer student, Oak Ridge National Laboratory.

FLetter, Stewart D. Ebneter to Charles Z. Serpan, U.S. Nuclear Regulatory Commission, "Development of Properties for Mild Steel Weld Metal Receiving PWHT at inter Critical and Super Critical Temperatures," February 7, 1984.
}

\section{Materials, Fabrication, and Heat Treatinent}

Four weldments were fabricated, two each with the shielded-metal-arc (SMA) and flux-cored-arc (FCA) processes. For each process, high- and low-carbon filler metals were used. The base plate was a 101.6-mm-thick (4-in.) plate of A 36 hot-rolled steel. The weldments are designated weld 1 (SMA, low carbon); weld 2 (SMA, high carbon); weld 3 (FCA, high carbon); and weld 4 (FCA, low carbon). The consumables used were 1/4-in.-diam SMA electrodes for welds 1 and 2 , and $3 / 32$-in.-diam flux-cored wire for welds 3 and 4 . Table 1 provides the chemical composition of each weld as well as the applicable specifications and manufacturers. Also shown in Table 1 are values for carbon equivalent according to the Welding Handbook. ${ }^{1}$ The carbon equivalent values range from 0.31 to 0.76 , with the SMA welds giving both the lowest and highest values.

A single V-groove joint geometry was used with a $45^{\circ}$ included angle and 50.8-mm-wide (2-in.) root gap. The very wide root gap was chosen to simulate a major repair in a large casting and, also, to provide an adequate volume of weld metal for the extensive heat-treatment test matrix. The SMA welds ( 1 and 2) were produced using stringer beads at 325- to 375-A dc-electrode positive (DCEP). The FCA welding (welds 3 and 4) was done at approximately $480 \mathrm{~A}$ and $30 \mathrm{~V}$ using $100 \%$ carbon dioxide shielding gas.

All four welds were sectioned and given simulated postweld heat treatments at temperatures from 621 to $899^{\circ} \mathrm{C}\left(1150\right.$ to $\left.1650^{\circ} \mathrm{F}\right)$ in increments of $56^{\circ} \mathrm{C}\left(100^{\circ} \mathrm{F}\right)$ and for times of 5,10 , 20 , and $40 \mathrm{~h}$ at each temperature. The weldments were furnace cooled from the PWHT 
Table 1. Summary of specifications and chemical compositions for welds 1 through 4

\begin{tabular}{|c|c|c|c|c|c|c|c|c|c|c|}
\hline \multirow{2}{*}{ Weld } & \multirow{2}{*}{ Type ${ }^{a}$} & \multirow{2}{*}{$\begin{array}{c}\text { Specification } \\
\text { and } \\
\text { manufacturer }\end{array}$} & \multicolumn{7}{|c|}{$\begin{array}{l}\text { Composition } \\
\text { (wt \%) }\end{array}$} & \multirow{2}{*}{$\begin{array}{l}\text { Carbon } \\
\text { equivalent }^{c}\end{array}$} \\
\hline & & & C & Mn & Si & Mo & $\mathbf{P}$ & S & v & \\
\hline 1 & SMA low C & E7018-A1, H & 0.041 & 0.72 & 0.35 & 0.40 & 0.020 & 0.013 & 0.007 & 0.31 \\
\hline 2 & SMA high C & E7018, M & 0.270 & 1.17 & 0.79 & 0.05 & 0.007 & 0.011 & 0.012 & 0.76 \\
\hline 3 & FCA high $C$ & E120T-KS, M & 0.169 & 1.38 & 0.61 & 0.25 & 0.012 & 0.021 & 0.024 & 0.67 \\
\hline 4 & FCA low C & E70T-1, T & 0.070 & 1.34 & 0.78 & 0.01 & 0.011 & 0.011 & 0.020 & 0.60 \\
\hline \multicolumn{11}{|c|}{ "SMA [=] shielded metal-arc, FCA $\{=\}$ flux cored-arc. } \\
\hline
\end{tabular}


temperature to $371^{\circ} \mathrm{C}\left(700^{\circ} \mathrm{F}\right)$ with cooling rates from about 6 to $8^{\circ} \mathrm{C}\left(11\right.$ to $\left.14^{\circ} \mathrm{F} / \mathrm{min}\right)$.

Charpy V-notch (CVN) and tensile specimens were machined in the transverse orientation such that crack propagation in the CVN specimens was in the welding direction.

Figure 1 schematically shows the location of specimens in the weldments, while Figures 2(a) and $(b)$ show the configuration of the test specimens. One tensile and five CVN specimens were machined and tested from each weld section, with two weld sections representing each heat treatment; thus, 2 tensile and 10 CVN specimens were tested for each heattreatment condition as well as for the as-welded condition. Table 2 provides the key used for identification of sections from which specimens were machined.

\section{Testing and Analysis Procedures}

Tensile tests were conducted at room temperature on a screwdriven tensile machine in accordance with the provisions of American Society for Testing and Materials (ASTM) E-8. The load versus time strip-chart test records were analyzed to obtain yield and ultimate strengths, and uniform and total elongations by constructing offset lines to allow for test system compliance.

Hardness tests were conducted with a Rockwell B (1/16-in.-diam) indenter and 100-kg load. Ten measurements for each condition were made and averaged.

CVN impact tests were conducted on a 407-J $(300-\mathrm{ft}-\mathrm{lb})$ pendulum-type Charpy machine in accordance with the provisions of ASTM E-23, except for the soaking time at temperature for which the provisions of ASTM E-184 were followed. Heated air and cold nitrogen gas were used to condition the specimens, and they were held at temperature sufficiently long that the entire specimen was at the test temperature. The tests were conducted over a suitable temperature range to obtain ductile-tobrittle transition behavior as well as the uppershelf toughness. The data for each heattreatment condition were fitted with a hyperbolic tangent function to allow for consistent determinations of transition temperatures and the upper-shelf energy (USE). The transition temperatures determined are those corresponding to the energy midway between the upper and lower shelves (designated $T_{0}$ ), and those (arbitrarily chosen) at 27 and $68 \mathrm{~J}$ (20 and $50 \mathrm{ft}-\mathrm{lb}$ ).

A time-temperature relationship was used to enable a more direct comparison of the effects of the various PWHT conditions. This so-called tempering parameter (TP) has the same form as that developed by Hollomon and Jaffee: ${ }^{2}$

$$
T P=T^{\star}(c+\log t),
$$

where $T$ is PWHT temperature in absolute units, $K\left({ }^{\circ} \mathrm{C}+273\right), c$ is a constant, and $t$ is the time at the PWHT temperature in hours.

Often, "c" is taken to be 20 , which was the number proposed by Larson and Miller to correlate creep-rupture data rather than tempering response. ${ }^{3}$ In this program, the test results were fitted with Eq. (1) to determine the best value for the constant "c." The results were quite varied, ranging nominally from about 10 to 20 , and a reasonable average value of 15 was chosen. Thus, the TP function used for all comparisons is:

$$
T P=T^{\star}(15+\log t)
$$

For the PWHT conditions of this study, TP values ranged from 14,000 to 19,500 .

\section{Results and Discussion}

\section{Hardness Results}

Tabular results of all the averaged hardness tests are provided in Tables A1 through A4 of Appendix A. Rockwell $B$ hardness (HRB) measurements for the four welds ranged from about 62 to 104 HRB. Weld 1, with results from about 62 to $91 \mathrm{HRB}$, exhibited the widest range of hardness. Weld 2, with results from about 82 to 100 , exhibited the narrowest range. Welds 1 and 2 have the lowest and highest carbon equivalents, respectively, of the four welds. Figures 3 through 6 show the hardness results for welds 1 through 4, respectively, plotted 


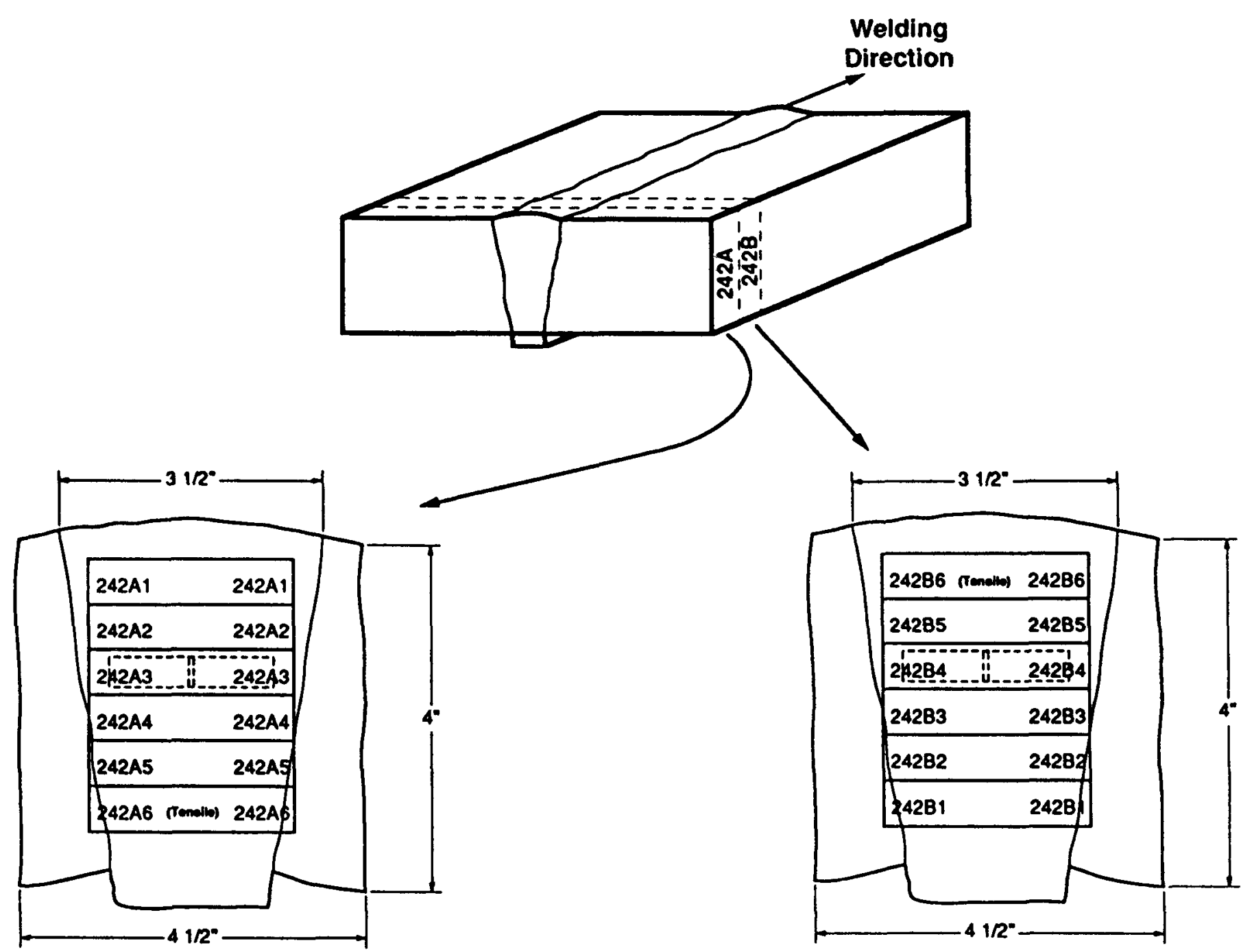

Figure 1. Schematic drawing showing the locations for machining of Charpy impact and tensile test specimen blanks in welds 1 through 4. 

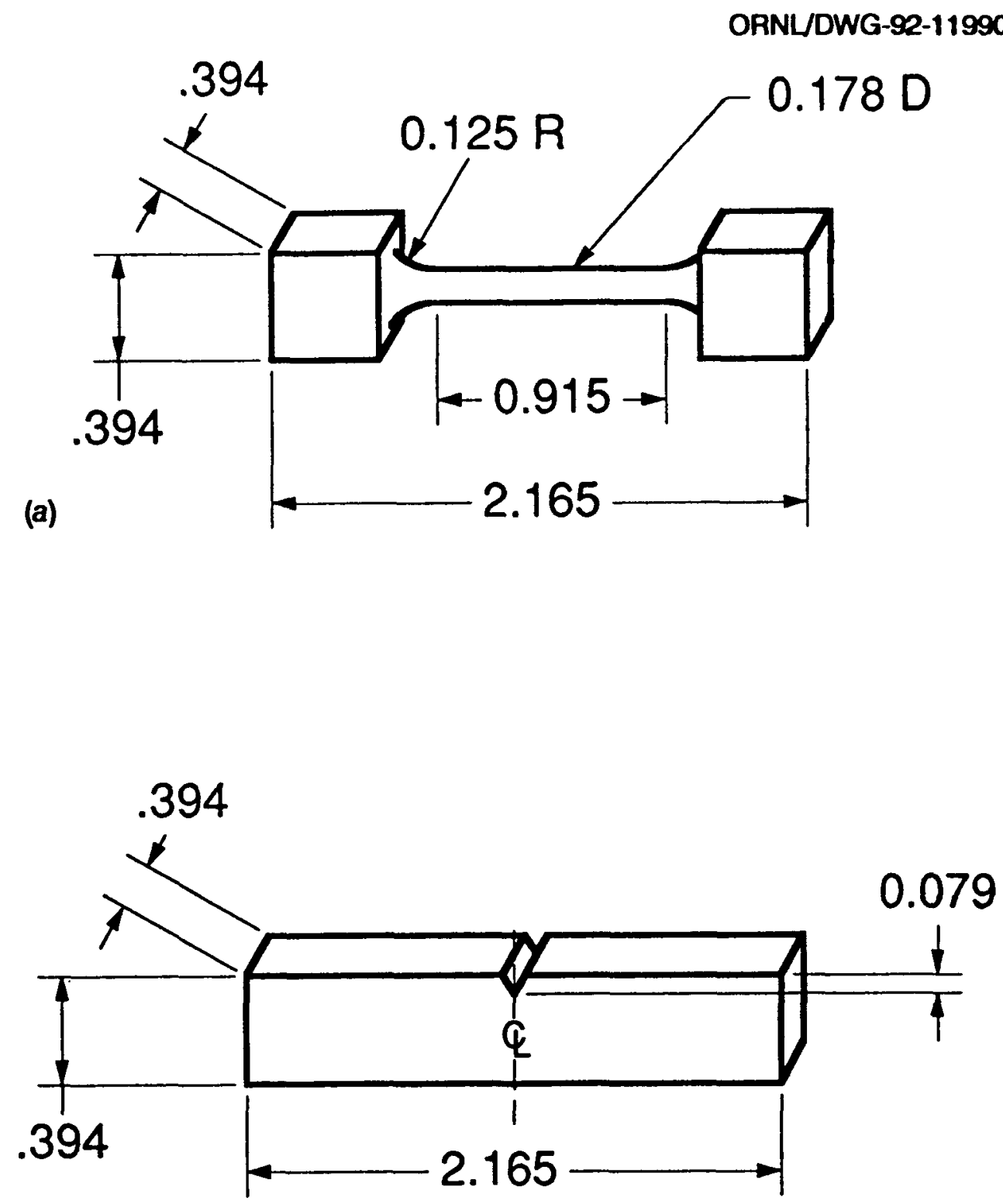

(b)

Dimensions in inches

$(25.4 \mathrm{~mm}=1$ in.)

Figure 2. Drawings of (a) tensile and (b) CVN impact test specimens for welds 1 through 4. 
Table 2. Numbering scheme used to identify sections from which test specimens were machined for welds 1 through 4

\begin{tabular}{|c|c|c|c|c|c|c|c|c|c|c|c|c|c|}
\hline \multirow{2}{*}{$\begin{array}{c}\text { WELD } \\
\#\end{array}$} & \multirow{2}{*}{$\begin{array}{c}\text { AS } \\
\text { WELDED }\end{array}$} & \multicolumn{4}{|c|}{$1150^{\circ} \mathrm{F}$} & \multicolumn{4}{|c|}{$1250^{\circ} \mathrm{F}$} & \multicolumn{4}{|c|}{$1350^{\circ} \mathrm{F}$} \\
\hline & & $5 \mathrm{hrs}$ & $10 \mathrm{hrs}$ & $20 \mathrm{hrs}$ & $40 \mathrm{hrs}$ & $5 \mathrm{hrs}$ & $10 \mathrm{hrs}$ & $20 \mathrm{hrs}$ & $40 \mathrm{hrs}$ & $5 \mathrm{hrs}$ & $10 \mathrm{hrs}$ & $20 \mathrm{hrs}$ & $40 \mathrm{hrs}$ \\
\hline 1 & 100 & 111 & 112 & 113 & 114 & 121 & 122 & 123 & 124 & 131 & 132 & 133 & 134 \\
\hline 2 & 200 & 211 & 212 & 213 & 214 & 221 & 222 & 223 & 224 & 231 & 232 & 233 & 234 \\
\hline 3 & 300 & 311 & 312 & 313 & 314 & 321 & 322 & 323 & 324 & 331 & 332 & 333 & 334 \\
\hline 4 & 400 & 411 & 412 & 413 & 414 & 421 & 422 & 423 & 424 & 431 & 432 & 433 & 434 \\
\hline
\end{tabular}

\begin{tabular}{|c|c|c|c|c|c|c|c|c|c|c|c|c|}
\hline \multirow{2}{*}{$\begin{array}{c}\text { WELD } \\
\#\end{array}$} & \multicolumn{4}{|c|}{$1450^{\circ} \mathrm{F}$} & \multicolumn{4}{|c|}{$1550^{\circ} \mathrm{F}$} & \multicolumn{4}{|c|}{$1650^{\circ} \mathrm{F}$} \\
\hline & $5 \mathrm{hrs}$ & $10 \mathrm{hrs}$ & $20 \mathrm{hrs}$ & 40 hrs & 5 hrs & 10 hrs & $20 \mathrm{hrs}$ & $40 \mathrm{hrs}$ & $5 \mathrm{hrs}$ & $10 \mathrm{hrs}$ & 20 hrs & 40 hrs \\
\hline 1 & 141 & 142 & 143 & 144 & 151 & 152 & 153 & 154 & 161 & 162 & 163 & 164 \\
\hline 2 & 241 & 242 & 243 & 244 & 251 & 252 & 253 & 254 & 261 & 262 & 263 & 264 \\
\hline 3 & 341 & 342 & 343 & 344 & 351 & 352 & 353 & 354 & 361 & 362 & 363 & 364 \\
\hline 4 & 441 & 442 & 443 & 4444 & 451 & 452 & 453 & 454 & 461 & 462 & 463 & 464 \\
\hline
\end{tabular}




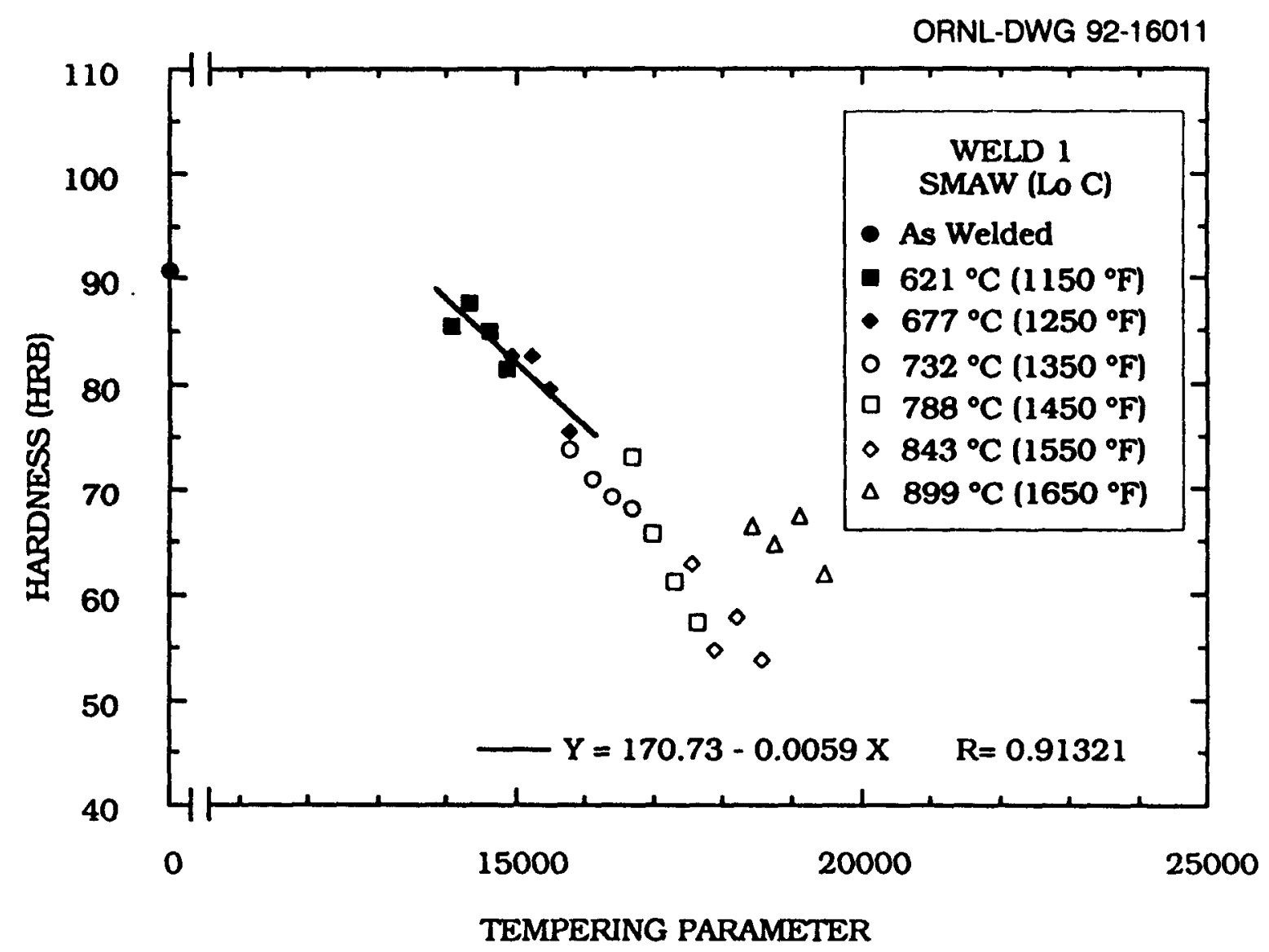

Figure 3. Plot of hardness (HRB) versus the TP, $T^{\star}(15+\log t)$, for weld 1 , a lowcarbon SMA weld. The equation shown is the result of a linear regression to the data at PWHT temperatures of $677^{\circ} \mathrm{C}\left(1250^{\circ} \mathrm{F}\right)$ and lower, while the solid line shows the resulting fit 
ORNL-DWG 92-16012

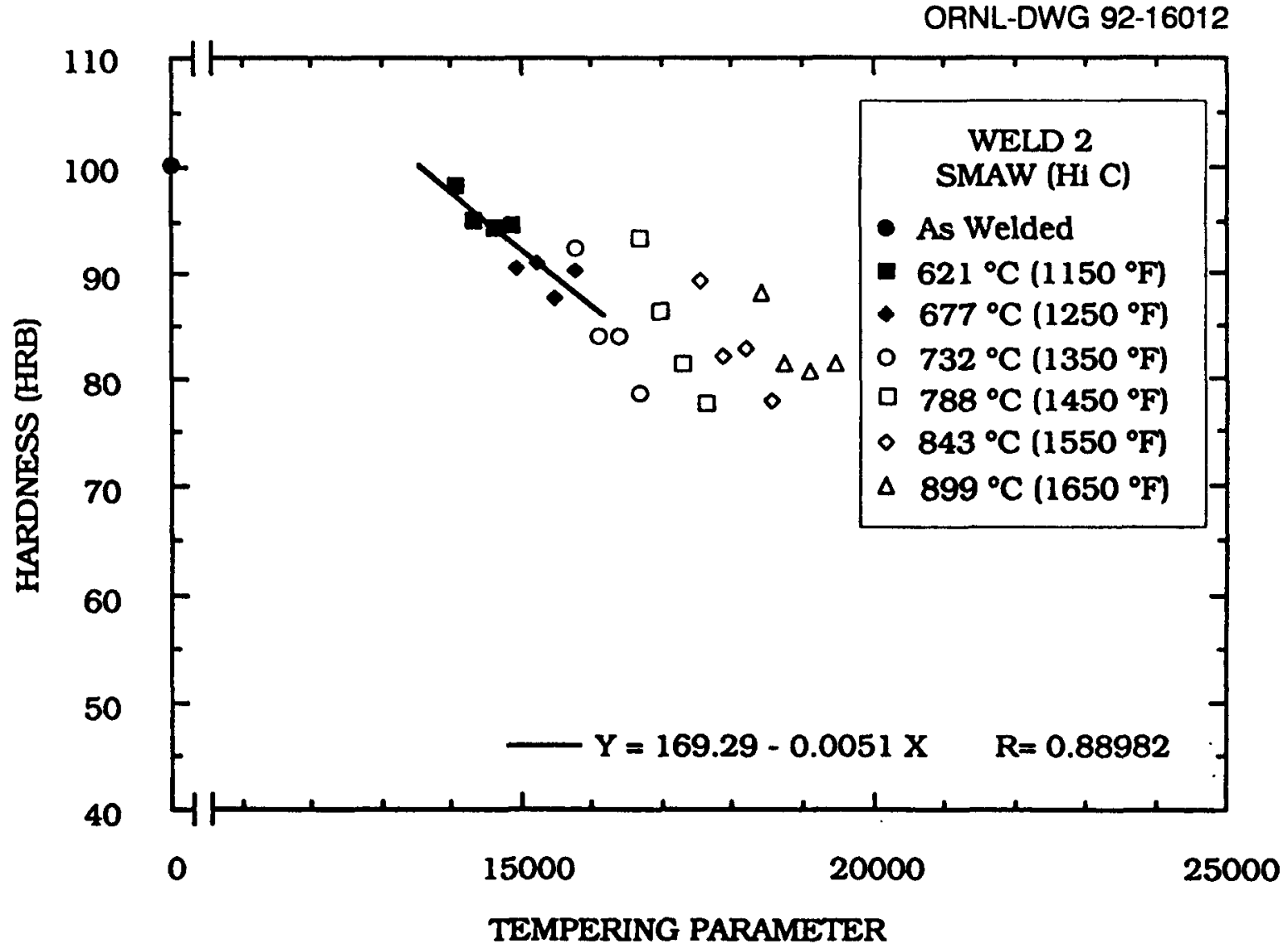

Figure 4. Plot of hardness (HRB) versus the TP, $T^{\star}(15+\log t)$, for weld 2 , a highcarbon SMA weld. The equation shown is the result of a linear regression to the data at PWHT temperatures of $677^{\circ} \mathrm{C}\left(1250^{\circ} \mathrm{F}\right)$ and lower, while the solid line shows the resulting fit. 
ORNL-DWG 92-16013

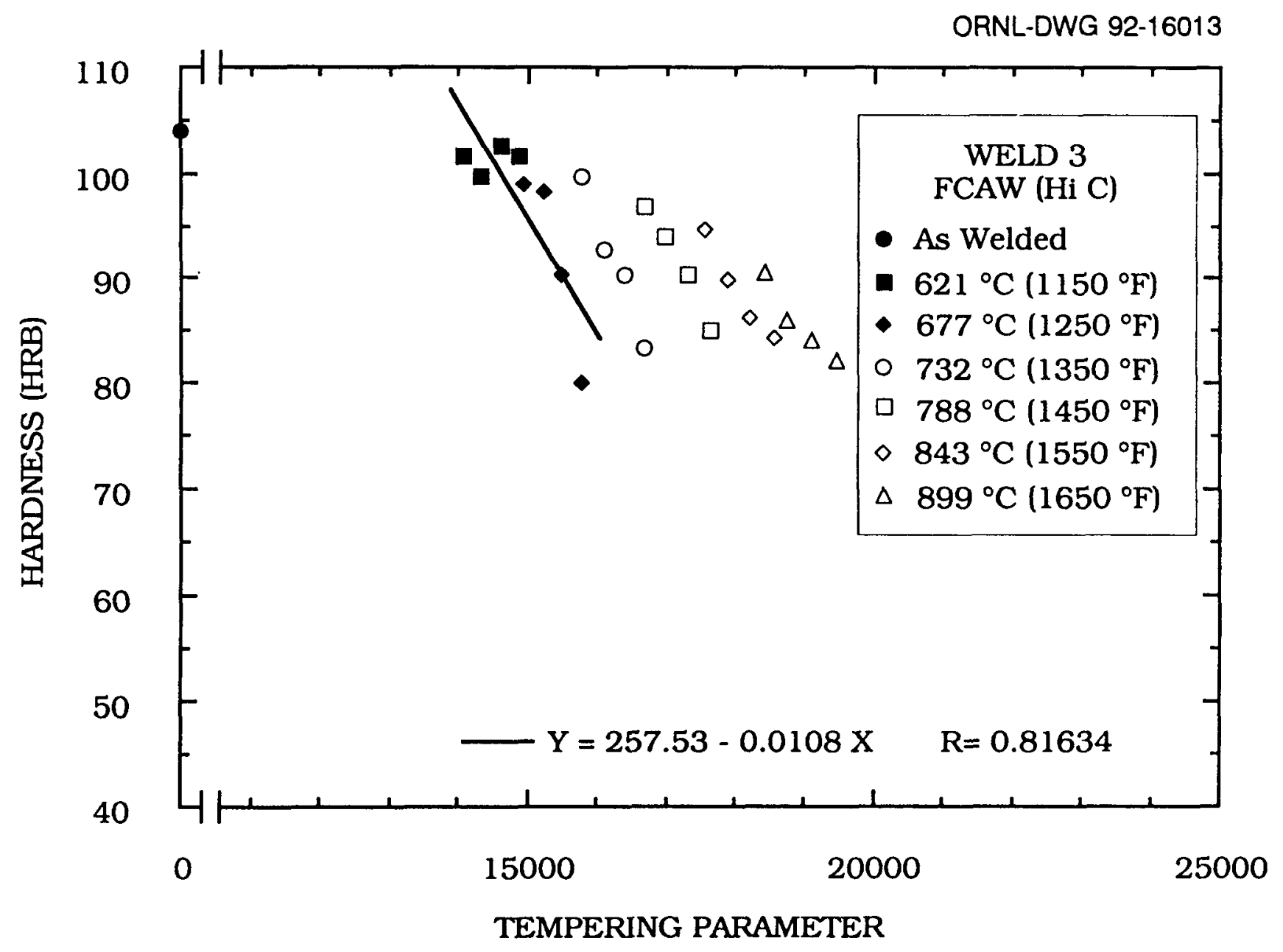

Figure 5. Plot of hardness (HRB) versus the TP, $T^{\star}(15+\log t)$, for weld 3 , a high-carbon FCA weld. The equation shown is the result of a linear regression to the data at PWHT temperatures of $677^{\circ} \mathrm{C}\left(1250^{\circ} \mathrm{F}\right)$ and lower, while the solid line shows the resulting fit. 
ORNL-DWG 92-16014

$\overrightarrow{0}$

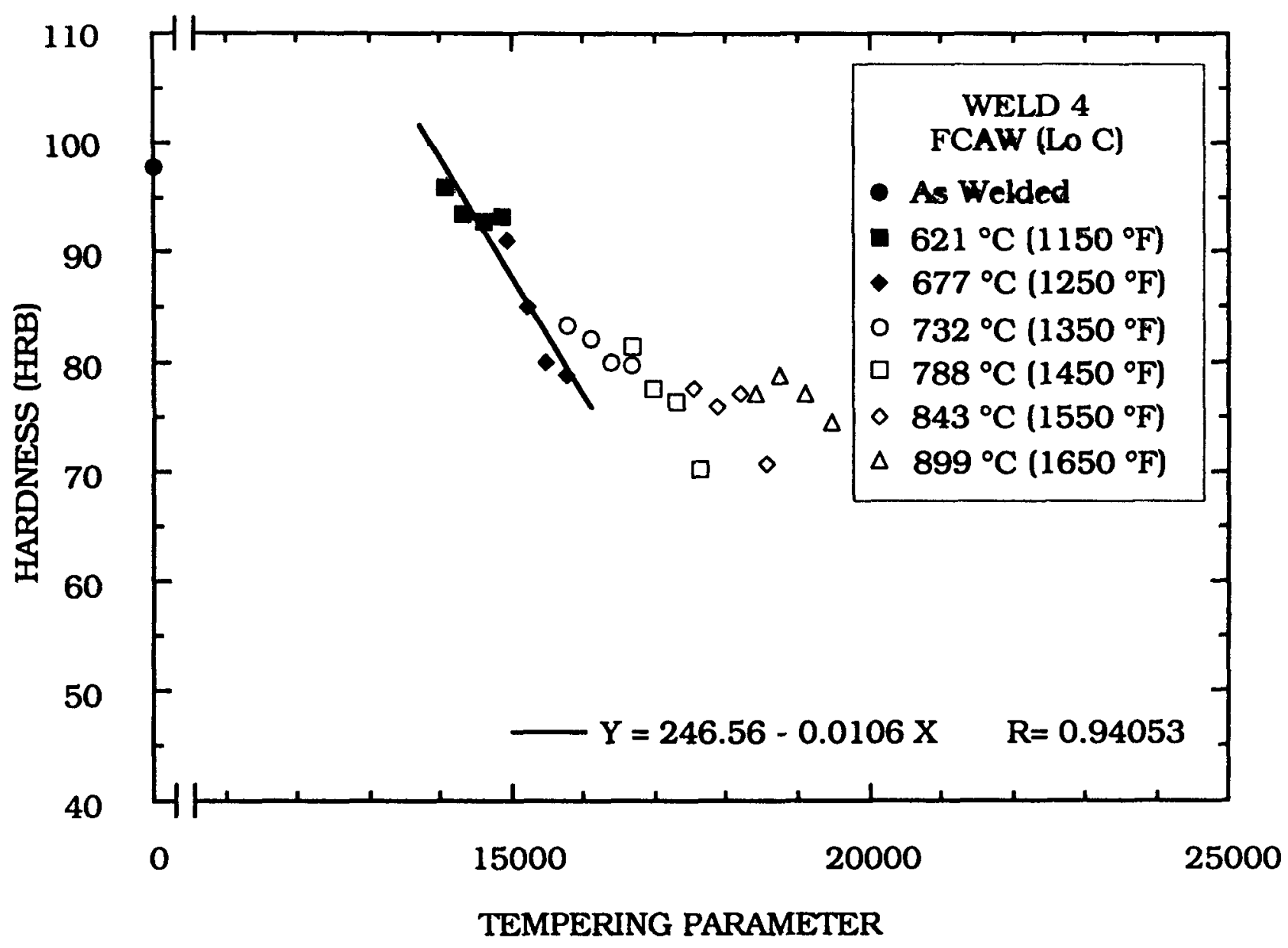

Figure 6. Plot of hardness (HRB) versus the TP, $T^{*}(15+\log t)$, for weld 4 , a low-carbon FCA weld. The equation shown is the result of a linear regression to the data at PWHT temperatures of $677^{\circ} \mathrm{C}\left(1250^{\circ} \mathrm{F}\right)$ and lower, while the solid line shows the resulting fit. 
versus the TP. The TP scale is broken to allow for plotting of the as-welded results on a scale that provides a reasonable graphical presentation. In all cases, the as-welded condition has the highest hardness for each weld.

In each case, the data for PWHT temperatures of $677^{\circ} \mathrm{C}\left(1250^{\circ} \mathrm{F}\right)$ and lower (those below the lower critical temperature), are denoted with filled symbols and fitted with a linear regression (the as-welded results are not included in the regressions). The equations for the linear regressions are provided on the individual plots, as are the coefficients of correlation (R), which range from 0.82 to 0.94 . Figure 7 provides a graphical comparison of the regression results for the four welds. In general, the scatter in results is greater for the higher temperature PWHTs (those above the A1 temperature and represented by the open symbols). The results at the higher temperatures were not fitted to the regression because they represent heat treatments at temperatures above normal PWHT temperatures. However, inspection of the data in each figure also reveals that, at the PWHT temperatures of $732^{\circ} \mathrm{C}\left(1350^{\circ} \mathrm{F}\right)$ and higher, the results showed generally consistent trends of decreasing hardness with increasing TP for each individual PWHT temperature, but the overall behavior showed too much scatter for inclusion in the trend line fitting.

As expected, for both the SMA and FCA welds, the high-carbon welds are harder than the low-carbon welds. Moreover, the two SMA welds exhibit similar hardness changes with increasing TP, as do the two FCA welds, with the response to heat treatment being much stronger for the FCA welds.

\section{Tensile Results}

Tabular results for all the tensile tests are provided in Tables B1 through B4 of Appendix B. In the as-welded condition, weld 1 is the weakest with average yield and ultimate strengths of 480 and $550 \mathrm{MPa}$ (69.7 and $79.8 \mathrm{ksi}$ ), while weld 3 is the strongest with average yield and ultimate strengths of 812 and $891 \mathrm{MPa}$ (118 and $129 \mathrm{ksi}$ ). The range of yield strengths for all the heat-treated welds is from 226 to $801 \mathrm{MPa}$ (32.8 to $116 \mathrm{ksi}$ ), while that of ultimate strengths is from 406 to $1131 \mathrm{MPa}$ (58.9 to $164 \mathrm{ksi}$ ). In the as-welded condition, the average total elongations range from about 10 to $13 \%$. For the heat-treated welds, the welds exhibited varying amounts of decreases and increases in the elongations with the highest total elongation exhibited by weld 1 at about $30 \%$.

Figures 8 through 11 show the yield and ultimate strength results for welds 1 through 4, respectively, plotted versus the TP. Again, a broken scale is used on the abscissa. As with the hardness data, filled symbols are used to denote results from PWHT temperatures at $677^{\circ} \mathrm{C}\left(1250^{\circ} \mathrm{F}\right)$ and lower, and linear regressions were similarly performed. For welds 1,2 , and 3 , the regression curves for yield and ultimate strength versus TP are essentially parallel. For weld 4, however, the yield strength decreases substantially faster with increasing TP than does the ultimate strength, at least over the fitted temperature range. Inspection of the figures reveals that the high-carbon welds show a more dramatic effect of PWHT at the higher temperatures, $732^{\circ} \mathrm{C}$ $\left(1350^{\circ} \mathrm{F}\right)$ and higher, than do the low-carbon welds, with the least effect being that of the low-carbon SMA weld 1, and the greatest effect being that of the high-carbon FCA weld 3. Those observations apply to both yield and ultimate strengths but are most evident for the ultimate strength results. In fact, weld 3 is the only weld that exhibited a heat-treated ultimate strength higher than that in the as-welded condition. The average as-welded ultimate strength for weld 3 was $891 \mathrm{MPa}(129 \mathrm{ksi})$, while it reached $1125 \mathrm{MPa}$ (163 ksi) after the PWHT at $732^{\circ} \mathrm{C}\left(1350^{\circ} \mathrm{F}\right)$ for $5 \mathrm{~h}$. In fact, the ultimate strength results from all the $732^{\circ} \mathrm{C}$ PWHTs of weld 3 were higher than those in the as-welded condition.

Figure 12 provides a graphical comparison of the yield strength response of the four welds. The two SMA welds exhibit similar hardness changes with increasing TP, as do the two FCA welds, with the response to heat treatment being much stronger for the FCA welds. These observations are similar to those for the 


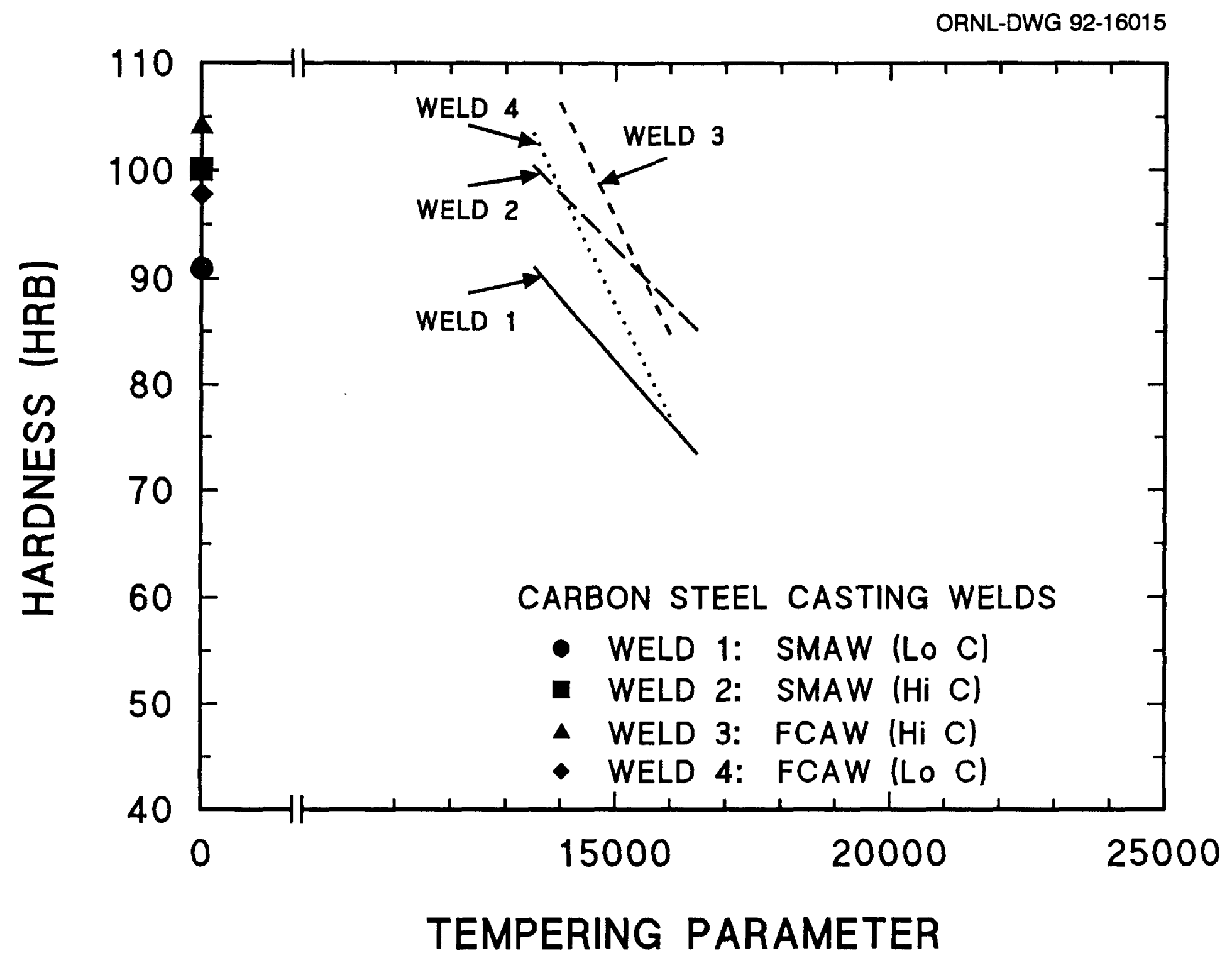

Figure 7. Comparison of linear regression curves to hardness (HRB) results versus the $T P, T^{\star}(15+\log t)$, for welds 1 through 4. 
ORNL-DWG 92-16016

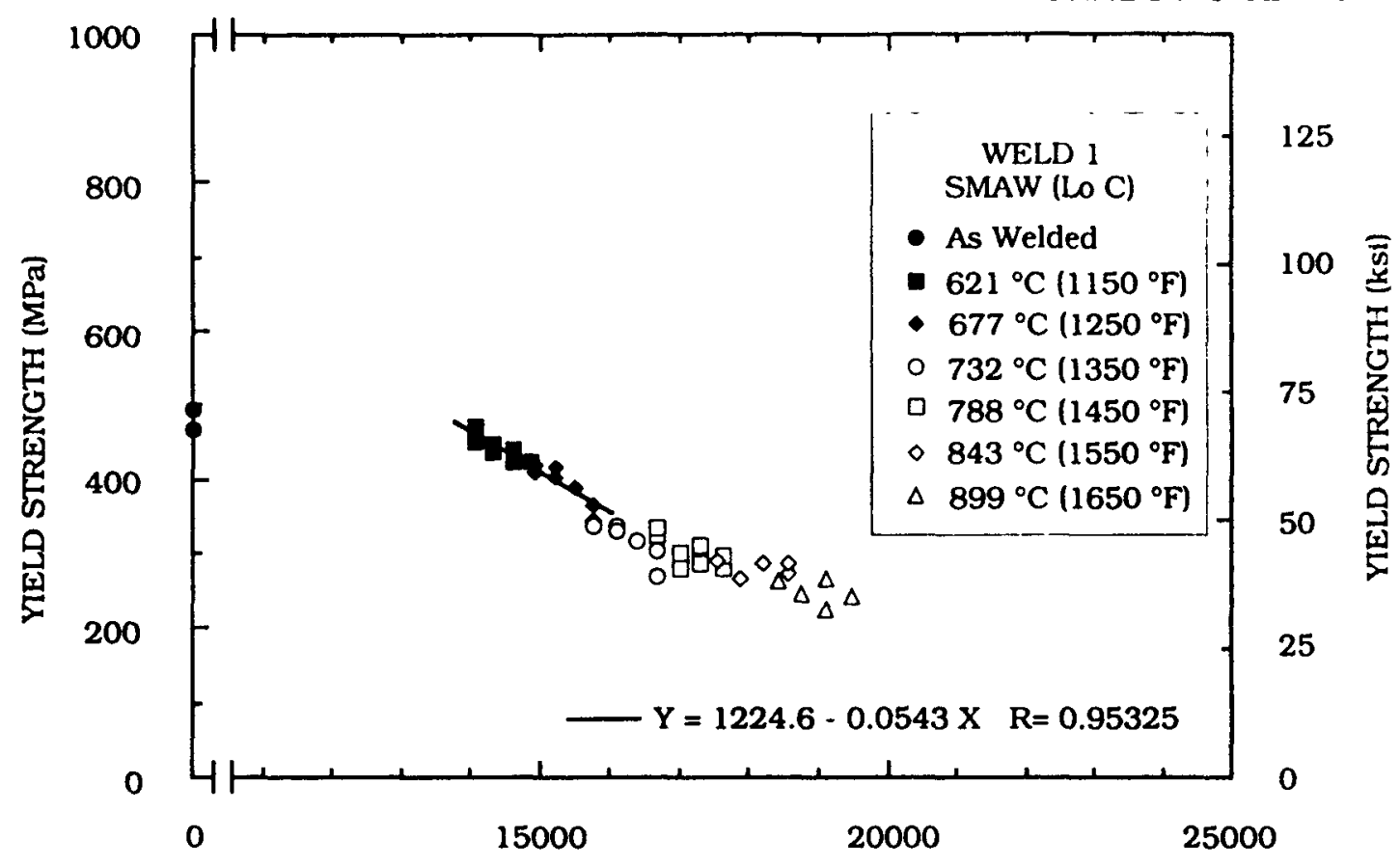

(a)

TEMPERING PARAMETER

ORNL-DWG 92-16017

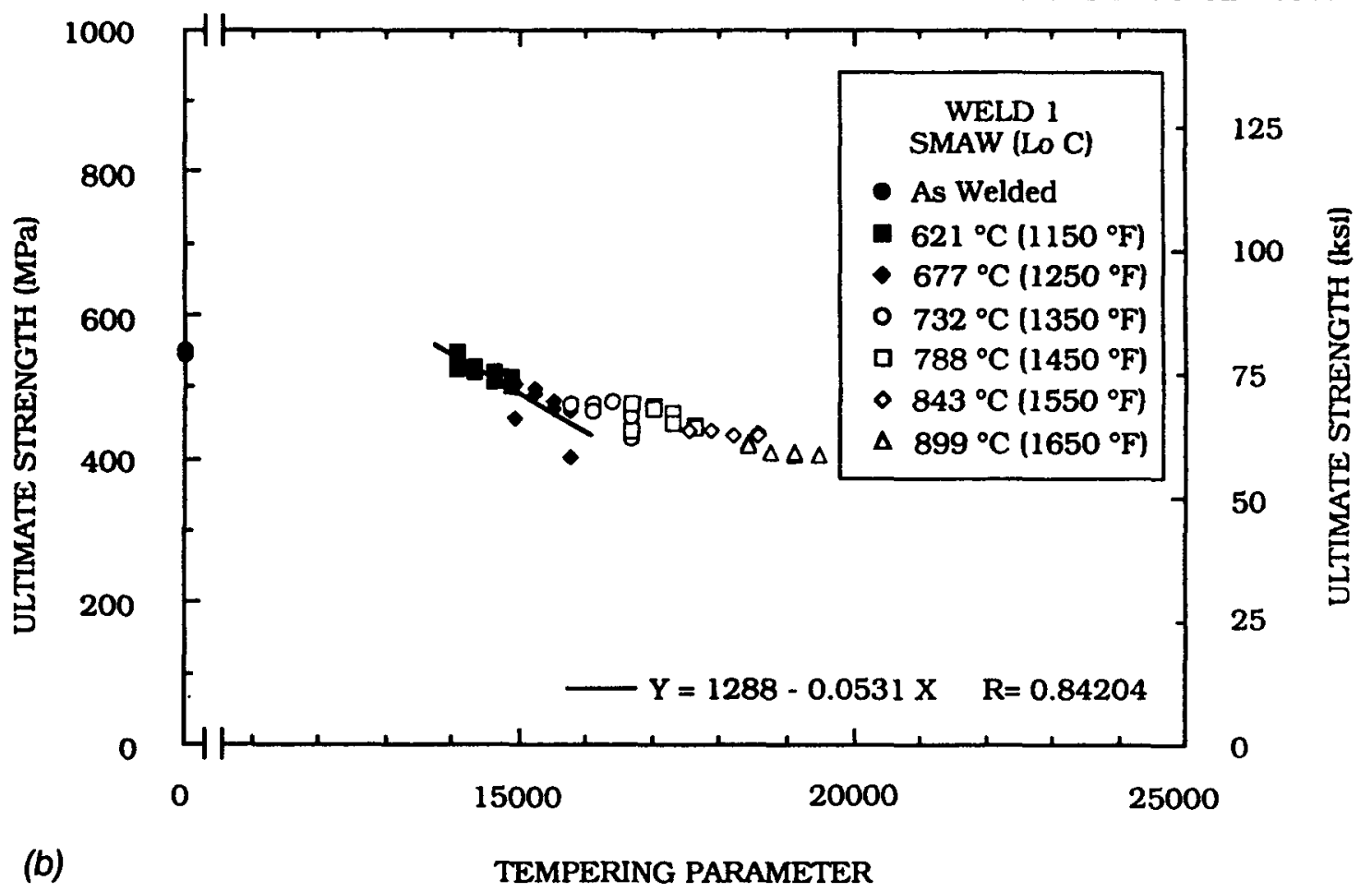

Figure 8. (a) Yield strength and (b) ultimate strength versus the TP, $T^{\star}(15+\log t)$, for weld 1, a low-carbon SMA weld. The equation shown is the result of a linear regression to the data at $\mathrm{PWHT}$ temperatures of $677^{\circ} \mathrm{C}\left(1250^{\circ} \mathrm{F}\right)$ and lower, while the solid line shows the resulting fit. 
ORNL-DWG 92-16018

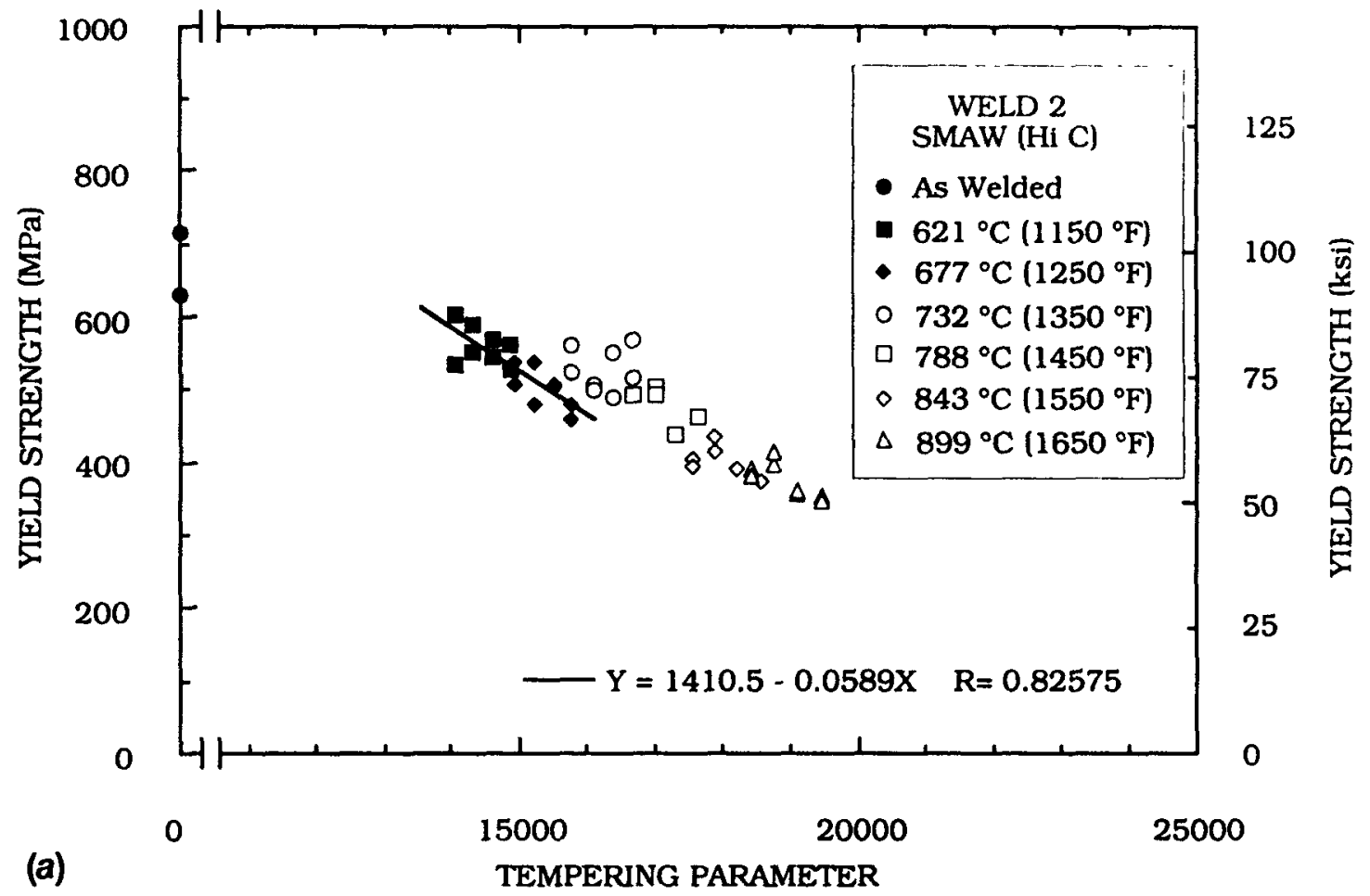

ORNL-DWG 92-16019

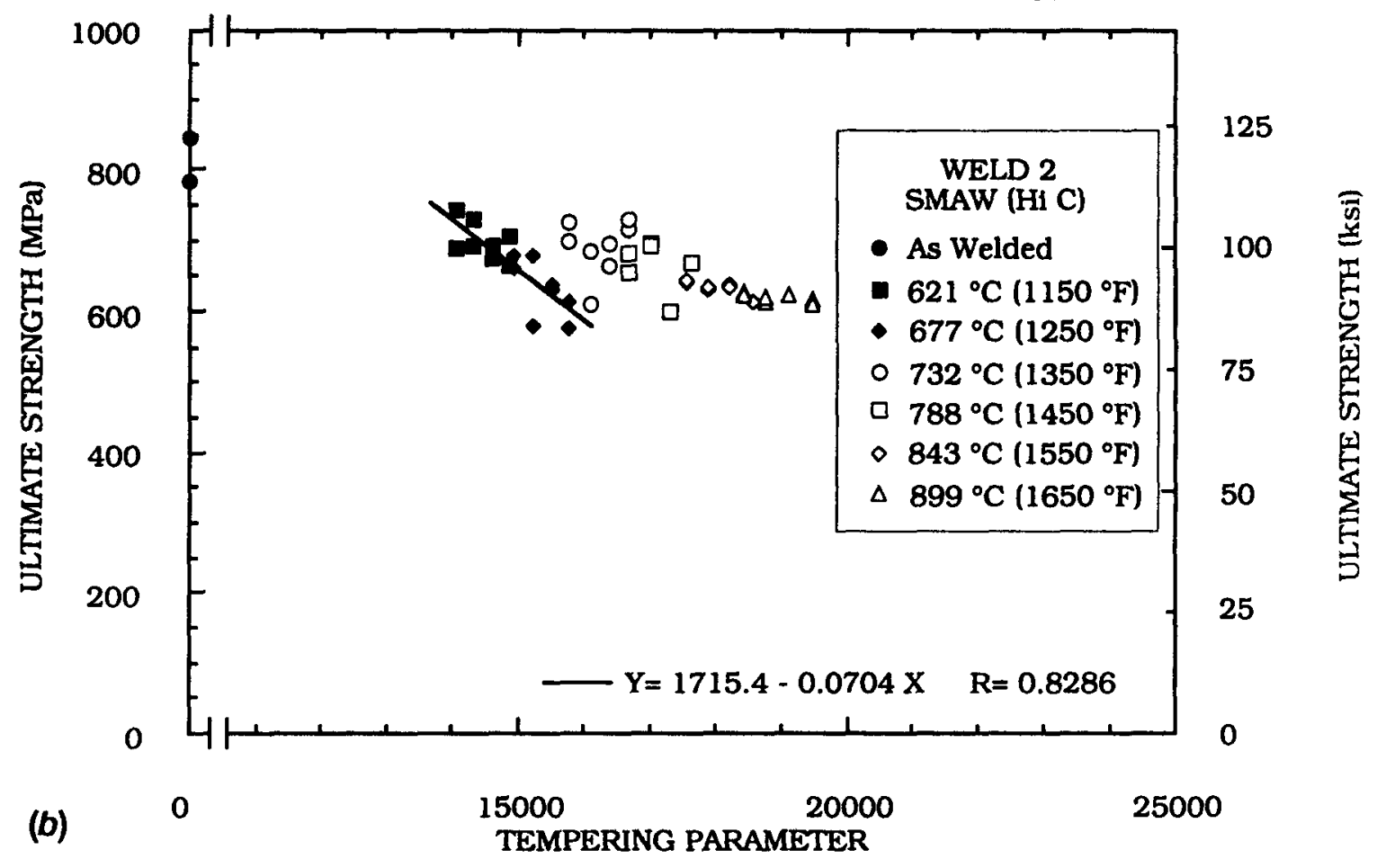

Figure 9. (a) Yield strength and (b) ultimate strength versus the TP, $T^{*}(15+$ $\log t$ ), for weld 2, a high-carbon SMA weld. The equation shown is the result of a linear regression to the data at PWHT temperatures of $677^{\circ} \mathrm{C}\left(1250^{\circ} \mathrm{F}\right)$ and lower, while the solid line shows the resulting fit. 
ORNL-DWG 92-16020

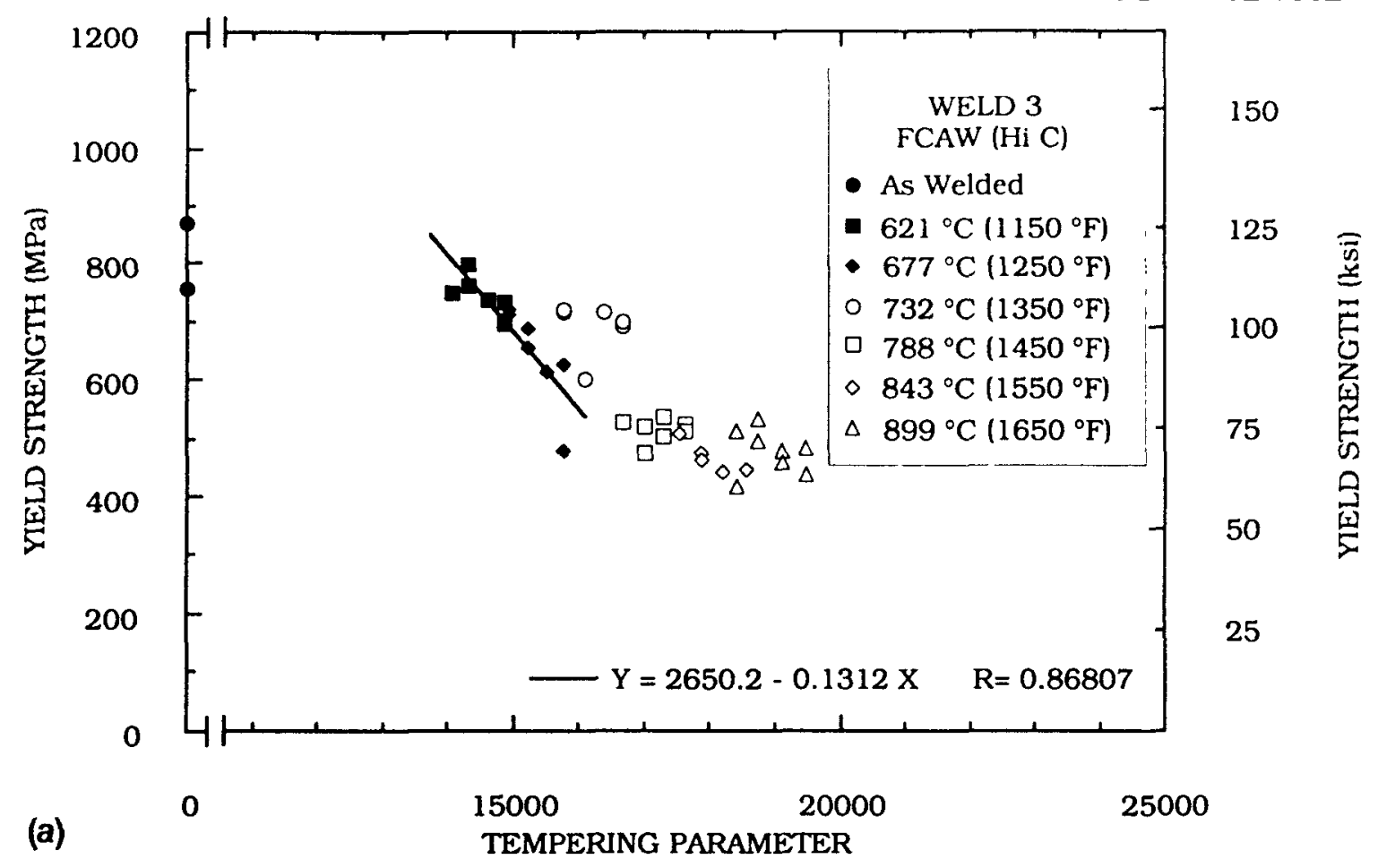

ORNL-DWG 92-16021

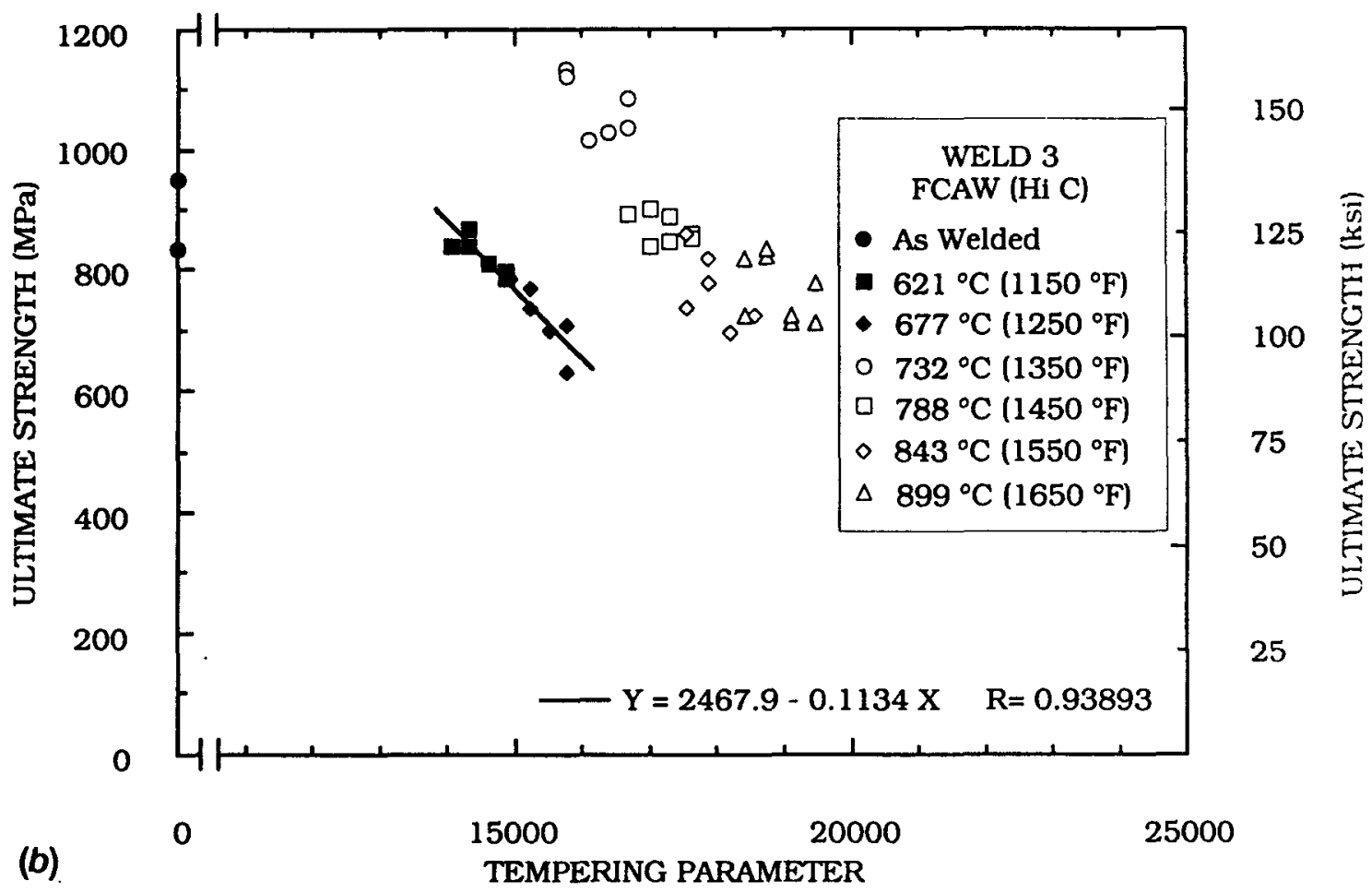

Figure 10. (a) Yield strength and (b) ultimate strength versus the $T P, T^{\star}(15+$ $\log t$ ), for weld 3 , a high-carbon FCA weld. The equation shown is the result of a linear regression to the data at PWHT temperatures of $677^{\circ} \mathrm{C}$ $\left(1250^{\circ} \mathrm{F}\right)$ and lower, while the solid line shows the resulting fit. 
ORNL-DWG 92-16022

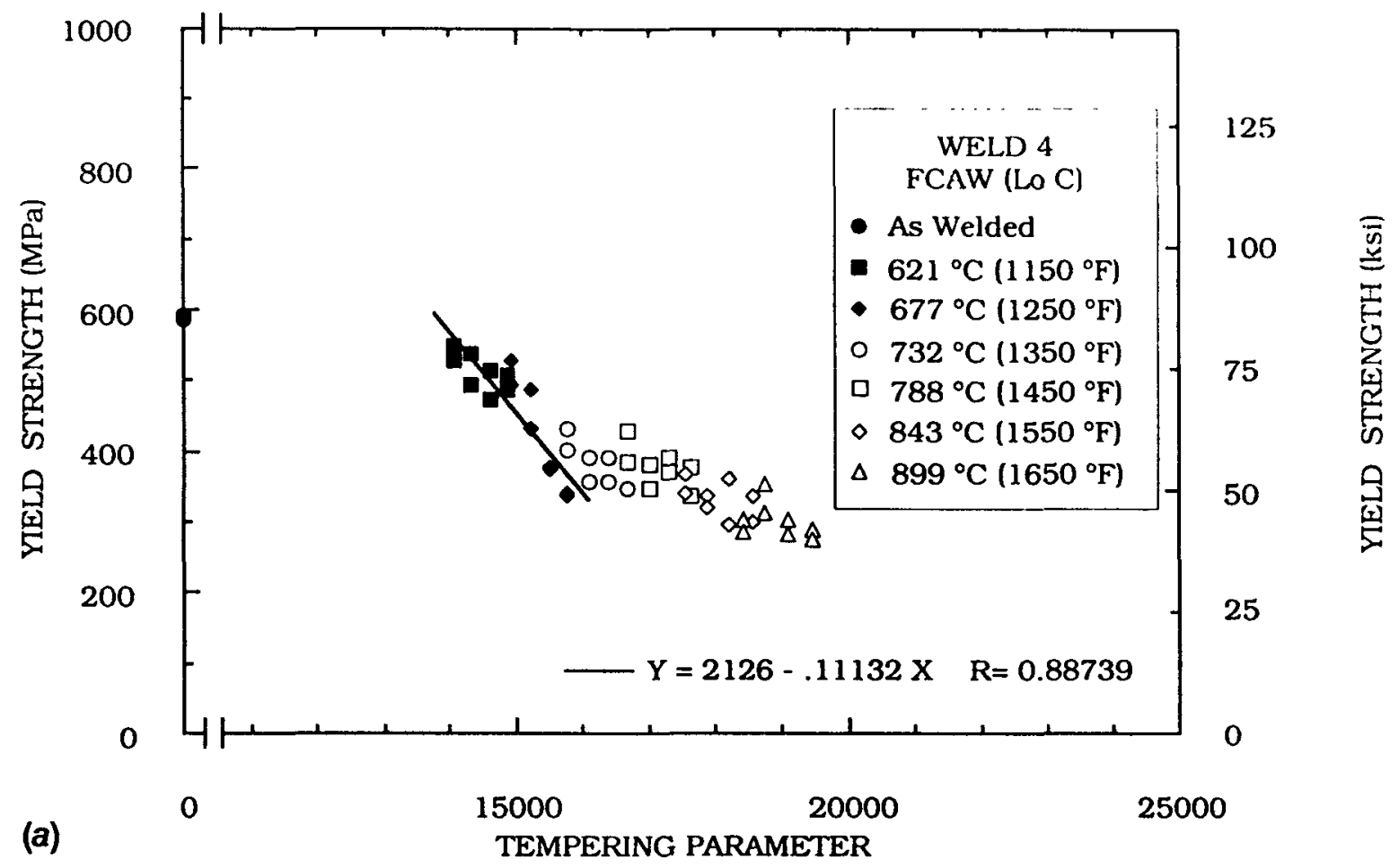

ORNL-DWG 92-16023

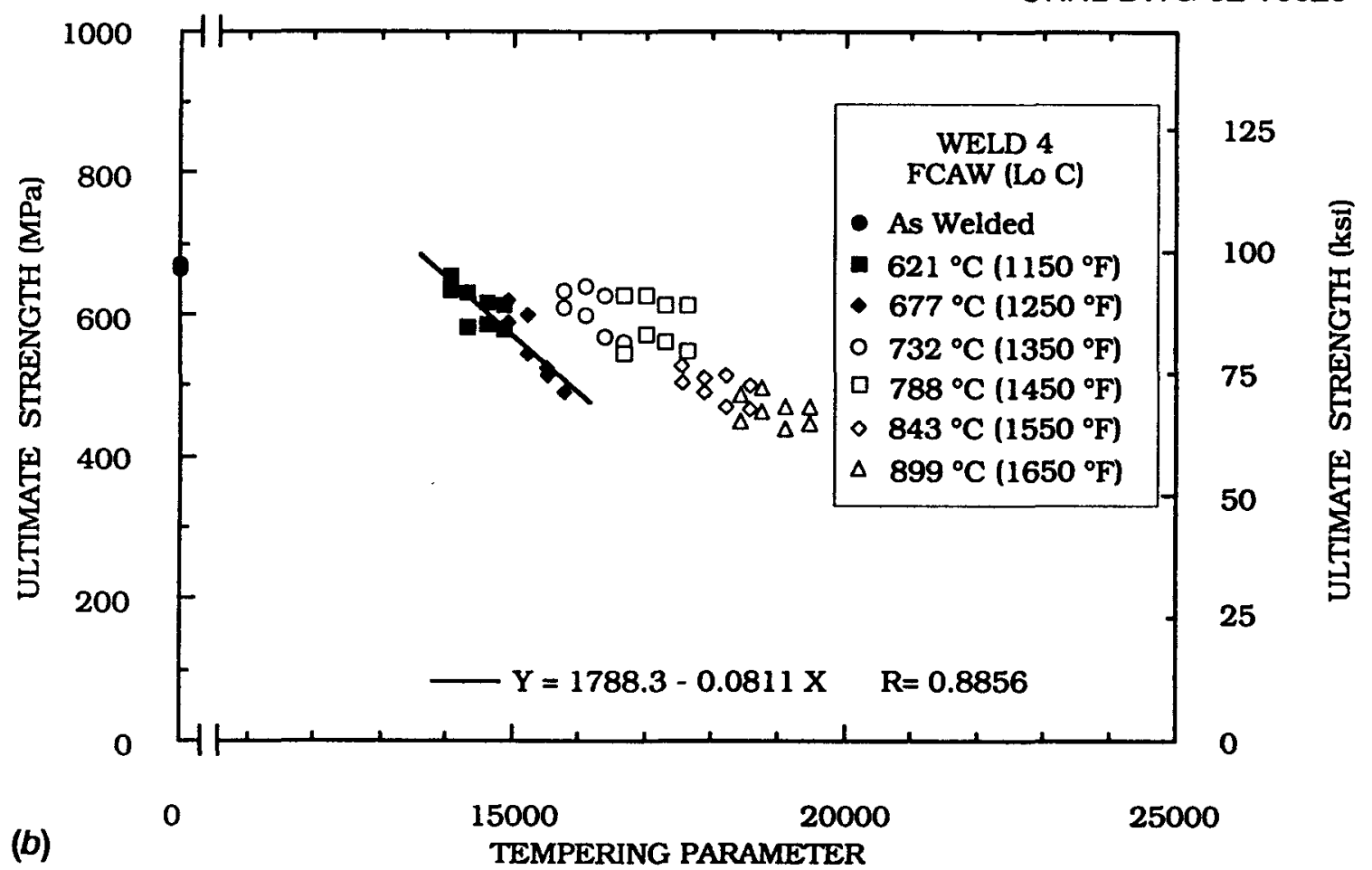

Figure 11. (a) Yield strength and (b) ultimate strength versus the $T P, T^{*}(15+\log t)$, for weld 4, a low-carbon FCA weld. The equation shown is the result of a linear regression to the data at PWHT temperatures of $677^{\circ} \mathrm{C}\left(1250^{\circ} \mathrm{F}\right)$ and lower, while the solid line shows the resulting fit. 


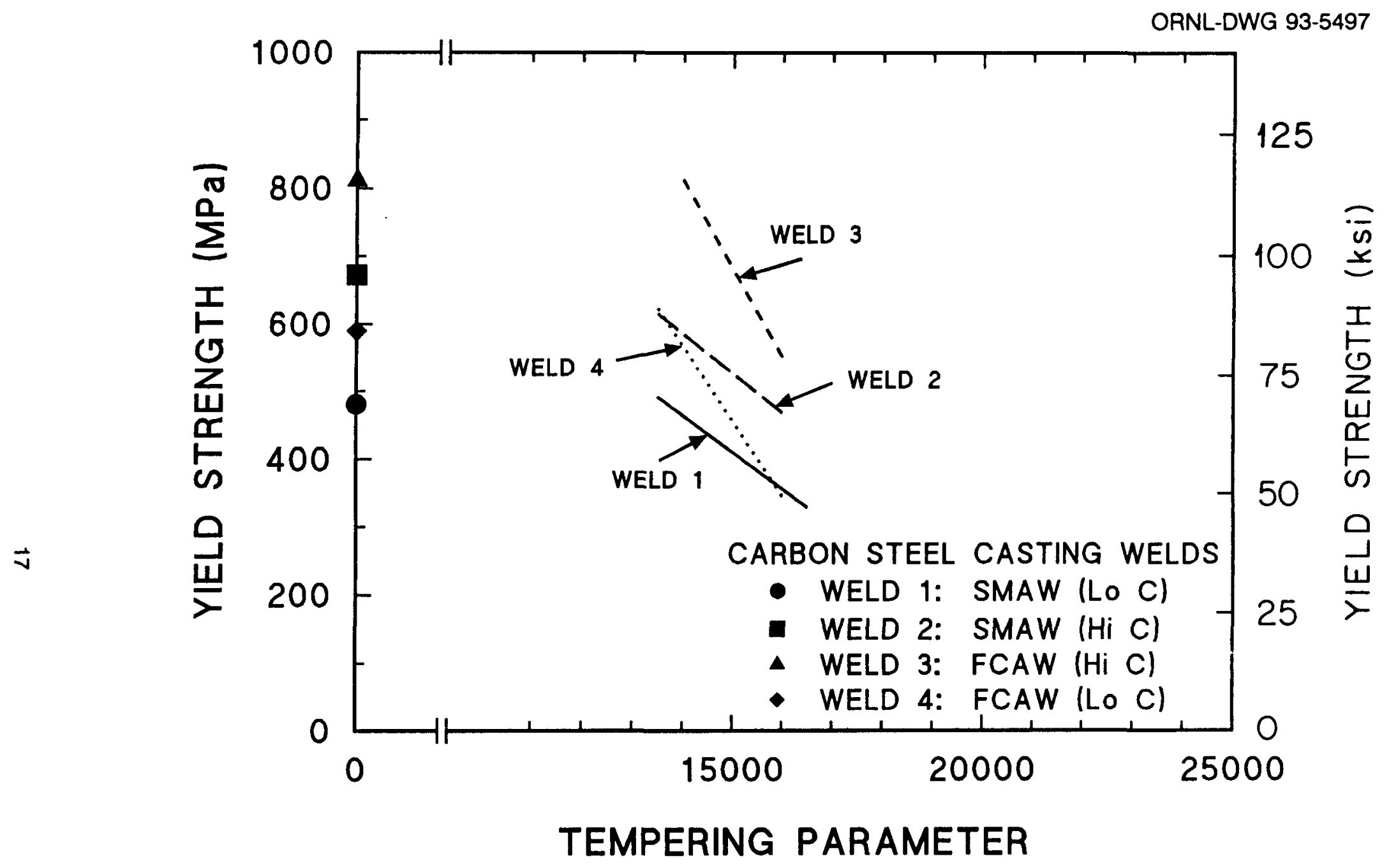

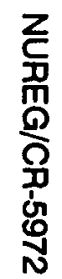

Figure 12. Comparison of linear regression curves to yield strength results versus the $T P, T^{\star}(15+$ $\log t$ ), for welds 1 through 4. 
hardness results presented earlier. Figure 13 shows a similar comparison for the ultimate strength results, which exhibit trends similar to those for the yield strengths.

\section{Charpy V-Notch Impact Results}

The individual CVN test results are provided in Tables C1 through C4 of Appendix C. As shown, there are up to $10 \mathrm{CVN}$ tests for each weld in the as-welded condition and in each PWHT condition. As mentioned earlier, a hyperbolic tangent function was used to fit the CVN data. The function has the following general form:

$$
E=A+B^{\star} \operatorname{Tanh}\left[\left(T-T_{0}\right) / C\right],
$$

where $E$ is absorbed energy (Joules); A, B, C, and $T_{0}$ are fitting constants [in this formulation, $(A+B)$ is the upper-shelf value and $(A-B)$ is the lower-shelf value]; and $T$ is test temperature $\left({ }^{\circ} \mathrm{C}\right)$. $A$ and $B$ have units of Joules; $T_{0}$ and $C$ are in ${ }^{\circ} \mathrm{C}$. In fitting the CVN data in this study, the lower-shelf energy was arbitrarily fixed at a low value of $5 \mathrm{~J}(3.7 \mathrm{ft}-\mathrm{lb})$ because little data were available at the lower temperatures to enable consistent fits. The resulting fits enabled consistent determination of the 27- and 68-J (20- and 50-ft-lb) transition temperatures and USE for each condition. The effects of PWHT on CVN toughness can then be consistently evaluated.

The results of those analyses are provided in Tables 3 through 6 for welds 1 through 4, respectively. The tables give the tanh fitting constants. as well as the 27- and $68-\mathrm{J}\left(\mathrm{TT}_{27}\right.$ and $\pi_{68}$ ) transition temperatures and the USE values. Figures 14 through 17 show the CVN energy versus test temperature for welds 1 through 4, respectively, in the as-welded condition. Figure 18 provides a graphical comparison of these curve fits. The $T_{0}$ temperatures (midpoint of the transition region) vary from $-62^{\circ} \mathrm{C}\left(-79^{\circ} \mathrm{F}\right)$ for weld 3 to $-7^{\circ} \mathrm{C}$ $\left(19^{\circ} \mathrm{F}\right)$ for weld 4 , while the $27-\mathrm{J}(20 \mathrm{ft}-\mathrm{lb})$ temperatures $\left(\pi_{27}\right)$ range from -81 to $-34^{\circ} \mathrm{C}$ $\left(-114\right.$ to $\left.-28^{\circ} \mathrm{F}\right)$. The USE values range from a very low $36 \mathrm{~J}$ (26 ft-lb) for weld 3 to $206 \mathrm{~J}$ $(152 \mathrm{ft}-\mathrm{lb})$ for weld 1 . Both the SMA welds have higher USE values than do the FCA welds. It is notable that weld 3, the high-carbon FCA weld, has a low $T_{0}$ temperature but the lowest USE. As shown in Table 5, weld 3 did not achieve $68 \mathrm{~J}$ in most cases. For both the SMA and FCA welds, higher carbon contents substantially decrease the USE. In the case of the FCA welds, the higher carbon content weld 3 had a substantially lower transition temperature than that for the lower carbon content weld 4. The opposite was true for the SMA welds, but the difference was not relatively large.

Figures 19 through 22 provide a series of plots that graphically depict the effect of PWHT on the transition temperatures and USE results for welds 1 through 4, respectively (note that a plot of $T_{68}$ versus TP is not given for weld 3 because of its low energy in almost every condition). In most cases, the heat-treated $\mathrm{T}_{0}$ and $\pi_{27}$ temperatures were higher than those in the as-welded condition. That is not, however, the case for the $\pi_{68}$ results. The scatter in transition temperature results overwhelmed trends that may exist and, in most of the cases, the coefficients of correlation were extremely low. Thus, linear regression fits to the transition temperature results are not shown. The highest $T_{0}$ temperatures, at about $100^{\circ} \mathrm{C}\left(212^{\circ} \mathrm{F}\right)$, are shown by the low-carbon FCA weld 4 after PWHT at $899^{\circ} \mathrm{C}\left(1650^{\circ} \mathrm{F}\right)$ for 10 and $20 \mathrm{~h}$. The USE results, however, were relatively well behaved, and linear regressions were performed as shown on the figures. In all four cases, the trend is for increasing USE with increasing TP. The scatter in USE results for the higher PWHT temperatures, however, was also large, and consistent trends were not observed. Figure 23 provides a graphical comparison of the USE results for the four welds. The relatively low USE of weld 3 is apparent. The change in USE for the low-carbon SMA weld 1 is greater than that for its high-carbon counterpart, but the opposite situation exists for the FCA welds with the high-carbon weld 3 showing greater changes than its low-carbon counterpart.

\section{Metallography}

Figures 24(a) through (d) show the microstructures of welds 1 through 4, respectively, in 


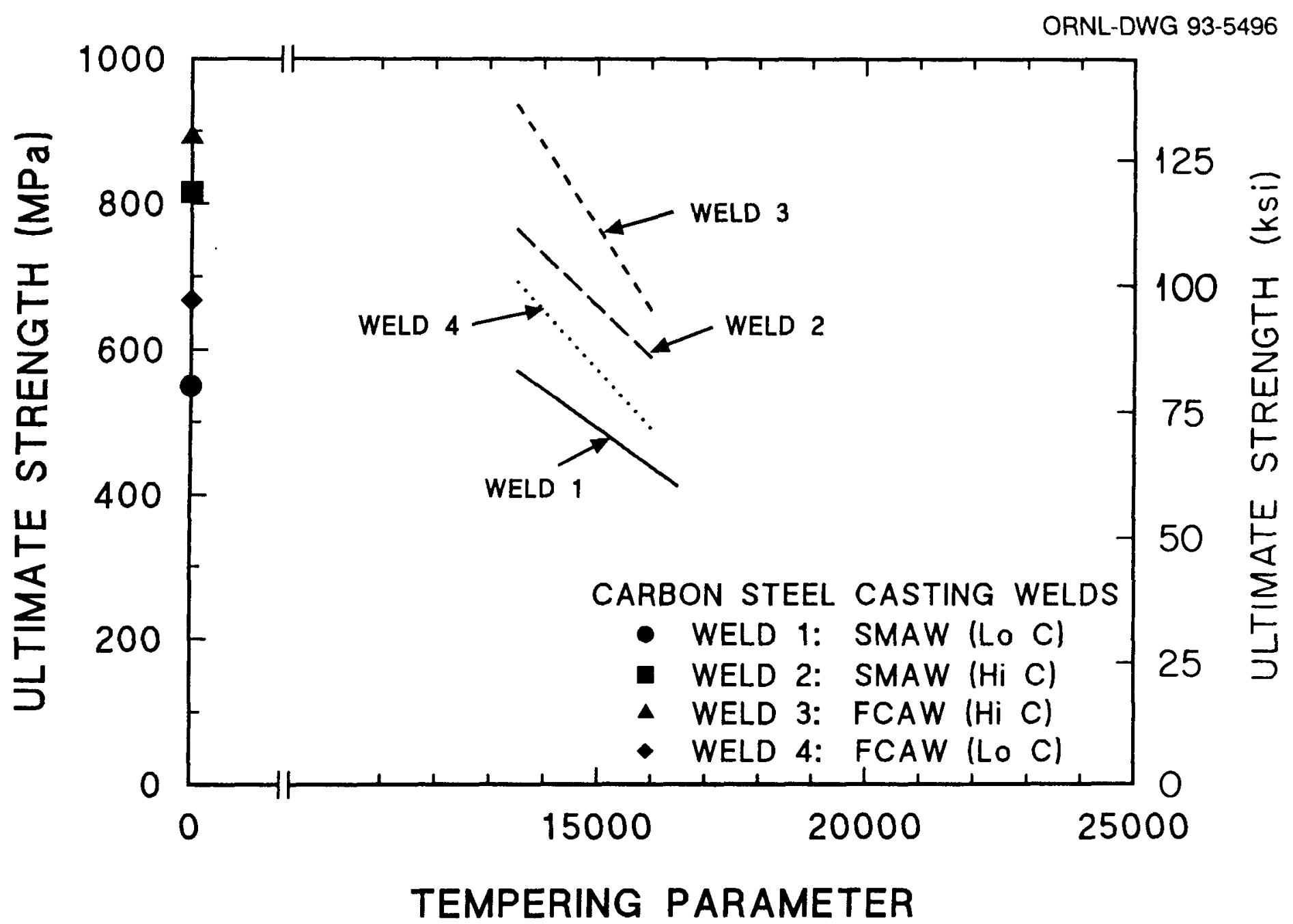

Figure 13. Comparison of linear regression curves to ultimate strength results versus the TP, $T^{\star}(15+\log t)$, for welds 1 through 4 . 


\begin{tabular}{|c|c|c|c|c|c|c|c|c|c|c|c|c|c|c|}
\hline \multicolumn{2}{|c|}{ ANT Thap } & \multirow{2}{*}{$\frac{\text { An TWRT }}{\text { (HLR }}$} & \multirow{2}{*}{$\frac{25}{\left(\times 10^{-3}\right)}$} & \multirow{2}{*}{$\frac{x}{(N)}$} & \multirow{2}{*}{ (ग) } & \multirow{2}{*}{$\frac{c}{(0)}$} & \multicolumn{2}{|c|}{10} & \multicolumn{2}{|c|}{$127 \mathrm{~J}$} & \multicolumn{2}{|c|}{ tow } & \multicolumn{2}{|c|}{ Usis } \\
\hline ('C) & $(6 \mathrm{~F})$ & & & & & & T'C & $7 \mathrm{~F})$ & $70^{\circ} \mathrm{C}$ & $(4)$ & 70 & $(4)$ & जा & $(t+-1 b)$ \\
\hline AW & $\mathbf{A W}$ & AW & 0 & 106 & TOI & 67 & -21.6 & 76.7 & -81.3 & -114.34 & 263.8 & 76.84 & 2066 & 152 \\
\hline 621 & 1150 & 5 & 14.04 & I5ा & 146 & 34 & 1.6 & 34.52 & -40.7 & 41.26 & -20.3 & 7.54 & 2288 & 219 \\
\hline 621 & 1150 & 10 & 14.31 & 162 & I57 & 43 & -14.4 & 7.08 & -70.1 & .94 .18 & -44.1 & -47.38 & 318 & 235 \\
\hline 621 & 1150 & 20 & 14.58 & 172 & 167 & 41 & -6. & 21.2 & -59.8 & .75 .64 & 35.6 & 32.08 & 340 & 250 \\
\hline 621 & 1150 & 40 & 14.85 & 199 & 194 & 28 & .8 & 33.44 & -38.1 & -36.58 & .21 .9 & -7.42 & 393 & 2290 \\
\hline 677 & 1250 & 5 & 14.91 & Th7 & 172 & 14 & -18.9 & -2.02 & 38.1 & 36.58 & -29.6 & -21.28 & 348 & 257 \\
\hline 677 & 1250 & 10 & 15.20 & 204 & 199 & 26 & -16.6 & 2.12 & -52.8 & 63.01 & -37.9 & 36.22 & 102 & 297 \\
\hline 677 & 1250 & 20 & 15.48 & 195 & 190 & 25 & -25.1 & -13.18 & .60 & -76 & 75.4 & 78.72 & 386 & 284 \\
\hline 677 & 1250 & 70 & T5.77 & T94 & 189 & $T$ & -24.5 & -12.1 & -26.2 & -15.16 & -25.5 & -13.9 & 384 & 283 \\
\hline 732 & 1350 & 10 & 16.09 & 2002 & I97 & 25 & -.5 & 31.1 & 35.7 & 32.26 & -21.1 & -5.88 & 388 & 284 \\
\hline 732 & 1350 & 20 & 16.39 & 193 & 188 & $\pi$ & -14.1 & 6.62 & -29.2 & -20.56 & -22.8 & -9.04 & 382 & 282 \\
\hline 732 & 1350 & 5 & 15.78 & 2022 & 197 & 31 & 4.5 & 20.9 & -48 & -54.4 & -30 & -22 & 309 & 295 \\
\hline 732 & 1350 & $40^{\circ}$ & 16.69 & 195 & 190 & 20 & -15.2 & 7.64 & 42.7 & 27.86 & 31.1 & -23.98 & 3835 & 284 \\
\hline 788 & 1450 & 20 & 17.29 & 188 & 193 & 38 & 10. & 30 & -43.3 & 45.94 & -21 & -5.8 & 300 & 288 \\
\hline 788 & 1450 & 5 & 16.66 & 208 & 204 & 25 & 3.8 & 38.84 & -31.3 & -24.34 & -17 & 1.4 & 414 & 305 \\
\hline 788 & 1450 & 40 & 17.61 & 198 & TS3 & I5 & -9.6 & 14.9 & 50.6 & -25.08 & -21.8 & -7.24 & 301 & 289 \\
\hline 788 & 1450 & 10 & 16.98 & 163 & T78 & 25 & 7.3 & 76.14 & -26.7 & -16.06 & -11.9 & 10.58 & 361 & 266 \\
\hline 645 & 1550 & 5 & 17.53 & $2008^{\circ}$ & 203 & 13 & 31.6 & -24.86 & 49.5 & -57.1 & -42.2 & -43.96 & 4II & 303 \\
\hline 843 & 1550 & 10 & 17.86 & 194 & 189 & 15 & -22.7 & -8.86 & -43.6 & 46.48 & 34.8 & 30.64 & 364 & 283 \\
\hline 843 & 1550 & 20 & 18.20 & 194 & 189 & I5 & 31.6 & -24.7 & -52.4 & 762.32 & 73.6 & 76.46 & 383 & 282 \\
\hline 843 & 1550 & $40^{\circ}$ & 18.64 & T79 & 174 & 10 & -17.8 & 20.04 & -31.3 & -24.34 & -215.4 & -13.72 & 363 & $26^{\circ}$ \\
\hline 899 & 1650 & 40 & 19.46 & 165 & 160 & 3 & 25 & -9.4 & -26.3 & -16.37 & $-2 \pi .8$ & -12.64 & 324 & 239 \\
\hline 899 & 1650 & 5 & 18.40 & 193 & 188 & 10 & -14.4 & 6.08 & -28.3 & -18.94 & -22.4 & 8.32 & 380 & 280 \\
\hline 899 & 1650 & 10 & 18.75 & 192 & 187 & 10 & -16.5 & 2.3 & -30.4 & -22.72 & -24.6 & -12.1 & 378 & 280 \\
\hline 899 & 1650 & 20 & I9.11 & 189 & 184 & 10 & -6.4 & 20.48 & -20.2 & -4.36 & -14.3 & 6.26 & 373 & 275 \\
\hline
\end{tabular}

a Aw-Aowelded 
Table 4. Summary of Charpy impact analysis for weld 2, high-carbon SMA weld

\begin{tabular}{|c|c|c|c|c|c|c|c|c|c|c|c|c|c|c|}
\hline \multicolumn{2}{|c|}{ Arat Tent } & \multirow{2}{*}{ 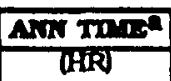 } & \multirow{2}{*}{$\frac{1.2}{\left(\times 10^{-3}\right)}$} & \multirow{2}{*}{$\frac{\pi}{\text { (J) }}$} & \multirow{2}{*}{ (5) } & \multirow{2}{*}{$\frac{C^{-}}{\left({ }^{\circ} \mathrm{C}\right)}$} & \multicolumn{2}{|c|}{10} & \multicolumn{2}{|c|}{1281} & \multicolumn{2}{|c|}{ rost } & \multicolumn{2}{|c|}{ des.5 } \\
\hline (6्C) & $7 \% 1)$ & & & & & & 785 & (PF) & $\left({ }^{\circ} \mathrm{C}\right)$ & $(4)$ & $7(\mathrm{C})$ & $7 \%$ & (ग) & (It-1b) \\
\hline $\mathbf{X W}$ & Aw & $A w$ & 0 & 48 & 4 & 64 & $-\Pi 1.7$ & 10.94 & -75.6 & .50 .05 & T9.9 & 67.82 & 91 & 67 \\
\hline 621 & $\pi 50$ & 10 & 14.31 & 69 & 5 & 47 & -7.5 & 18.5 & 39.5 & 39.1 & 0.5 & 32.8 & 113 & 83 \\
\hline 621 & 1150 & 5 & 24.04 & 62 & 57 & 67 & .8 & 36.44 & 76.9 & -52.42 & 8.4 & 77.12 & I18 & 87 \\
\hline 621 & 1150 & 20 & 14.58 & 65 & 60 & 62 & -2.7 & 27.14 & -49 & -56.2 & 0 & 32 & 126 & 93 \\
\hline 621 & 1150 & 40 & 14.85 & 69 & 64 & 52 & -1. & 30.2 & -41.7 & -46.06 & -1.6 & 29.12 & I32 & 98 \\
\hline 677 & 1250 & 5 & 14.91 & 66 & 61 & 56 & -1. & 30.2 & -43.9 & -47.02 & 0.5 & 3.9 & 128 & 94 \\
\hline 677 & 1250 & 10 & 15.220 & 69 & 64 & 59 & -5.1 & 22.82 & -51.4 & -60.52 & -5.7 & 21.74 & 132 & 98 \\
\hline 677 & 1250 & 20 & 15.48 & 73 & 68 & 46 & -9.8 & 14.18 & -47 & -52.6 & -13.5 & 7.7 & 142 & 105 \\
\hline 677 & 1250 & 40 & 15.77 & 73 & 68 & 57 & 8.7 & 77.66 & 38.3 & 36.94 & 7.8 & 70.64 & 140 & 103 \\
\hline 732 & 1350 & 5 & 15.78 & 59 & 54 & 56 & -6.6 & 20.12 & 45 & -49 & 2.8 & 37.04 & 113 & 83 \\
\hline 732 & 1350 & 10 & 16.09 & 66 & 61 & 61 & -5.6 & 21.92 & -51.6 & 760.88 & 3.2 & 26.24 & 126 & 93 \\
\hline 732 & 1350 & 20 & 16.39 & 53 & 48 & 48 & -16.5 & 2.3 & -45.1 & 49.18 & -0.7 & 30.74 & 101 & 74 \\
\hline 732 & 1350 & 40 & $16.69^{\circ}$ & 56 & 51 & 45 & -21.6 & 7.88 & .50 .5 & -58.9 & -10.5 & 13.1 & 707 & 79 \\
\hline 788 & 1450 & 5 & 16.66 & 59 & 64 & 88 & 0 & 32 & -59.6 & -75.28 & 14.8 & 38.64 & 113 & 83 \\
\hline 788 & 1450 & 10 & 16.98 & 62 & 58 & 63 & To. & 50 & -35.4 & -31.42 & 15.4 & 39.72 & T2T & 89 \\
\hline 788 & 1450 & 20 & 17.28 & 65 & 60 & 63 & 25. & 77 & -21.6 & -6.7 & 28.4 & 83.12 & 125 & 92 \\
\hline 788 & 1450 & 40 & 17.61 & 65 & 60 & 75 & 21.2 & 70.16 & -35 & -31 & 24.8 & 76.64 & $\mathrm{~T} 25$ & 92 \\
\hline 843 & 1550 & 40 & 18.54 & 56 & 51 & 50 & 40.6 & 105.08 & 8.6 & 47.48 & 33.2 & 127.76 & 106 & 78 \\
\hline 843 & 1550 & 20 & 18.250 & 67 & 62 & 63 & 52.2 & 125.96 & 4.3 & 39.74 & 533.3 & 121.94 & T29 & 95 \\
\hline 843 & 1550 & 5 & 17.53 & 56 & 51 & 45 & 23. & 73.4 & 7.1 & 21.02 & 33.7 & 92.66 & 107 & 79 \\
\hline 843 & 1550 & 10 & 17.86 & 67 & 62 & 50 & T5.4 & 59.72 & -23.2 & -9.76 & 15.8 & 60.44 & 130 & 96 \\
\hline 899 & $1660^{\circ}$ & 10 & 18.76 & 70 & 66 & 63 & 26.8 & 80.26 & -22.8 & -8.04 & 26 & 77 & 136 & 99 \\
\hline 899 & 1650 & 20 & T9.n & 56 & 51 & 63 & 48.6 & T19.48 & 8.1 & 46.58 & 63.2 & 145.76 & 108 & 79 \\
\hline 889 & 1650 & 40 & 18.46 & 58 & 63 & 63 & 46.8 & 116.24 & 5 & $\pi$ & 68.8 & 137.84 & $\pi$ & 82 \\
\hline $899^{\circ}$ & 1650 & 5 & 18.40 & 59 & 54 & 63 & 32.1 & 89.78 & -10.2 & 13.62 & 26.5 & 109.94 & IIR & 83 \\
\hline
\end{tabular}

aW-As-wedded 


\begin{tabular}{|c|c|c|c|c|c|c|c|c|c|c|c|c|c|c|}
\hline \multicolumn{2}{|c|}{ ANT T.PT } & \multirow{2}{*}{\begin{tabular}{|c|} 
AN TINAM \\
(HIR)
\end{tabular}} & \multirow{2}{*}{$\frac{13 .}{\left.610^{-3}\right)}$} & \multirow{2}{*}{$\frac{x}{\text { (J) }}$} & \multirow{2}{*}{ का } & \multirow{2}{*}{$\frac{c}{(-C)}$} & \multicolumn{2}{|c|}{10} & \multicolumn{2}{|c|}{$127 \mathrm{~J}$} & \multicolumn{2}{|c|}{2600} & \multicolumn{2}{|c|}{$0: 5$} \\
\hline TECT & $7 F$ & & & & & & 70 & $7 \mathrm{Mr}$ & (E) & $7 \%$ & $7 \mathrm{C}$ & $7 \%$ & (十) & (11-16) \\
\hline AW & AW & Aw & 0 & 20 & 15 & 36 & 761.9 & -70.45 & $2 x$ & -47.2 & b & 5 & 36 & 26 \\
\hline 621 & 1150 & 5 & 14.04 & 30 & 25 & 75 & -13.2 & 8.24 & -21.3 & -6.34 & 5 & $\mathbf{b}$ & 34 & 40 \\
\hline 621 & 1150 & 10 & T4.31 & 30 & 25 & 59 & -2.3 & 27.86 & -10.1 & 13.82 & 6 & $\mathbf{b}$ & 56 & $4 \pi$ \\
\hline 621 & 1150 & 20 & 14.58 & 28 & 23 & 49 & -7.2 & 19.04 & -10 & 14 & $\mathbf{b}$ & b & 32 & 38 \\
\hline 621 & T150 & 40 & 14.85 & 32 & 27 & 41 & -7.3 & 18.86 & -15.5 & $4 \pi$ & $\mathbf{b}$ & $\mathbf{b}$ & 20 & 44 \\
\hline 677 & 1250 & 5 & 14.91 & 34 & 29 & 61 & -10.9 & 12.38 & -26.2 & -15.16 & b & $b$ & 63 & 47 \\
\hline 67 & 1250 & 10 & 15.20 & 40 & 35 & 53 & 4.7 & 23.54 & -25.1 & -13.18 & 55.9 & 132.62 & 74 & 55 \\
\hline 677 & 1250 & 20 & 15.48 & 45 & 40 & 78 & T9.9 & 67.82 & -18.1 & 70.38 & 69.4 & 156.92 & 86 & 63 \\
\hline 677 & $1250^{\circ}$ & 40 & T5.77 & 45 & 40 & 52 & 32. & 89.6 & 7 & 74.6 & 67.7 & $15 \times 866$ & 87 & 62 \\
\hline 732 & 1350 & 5 & 15.78 & 16 & 11 & 75 & -91.2 & -132.16 & C & c & 6 & b & 27 & 20 \\
\hline 732 & 1350 & 10 & 16.09 & 18 & 13 & 72 & 33.4 & -28.12 & 21.6 & 70.88 & b & b & 32 & 23 \\
\hline 732 & 1350 & 20 & 16.39 & 19 & 14 & 128 & 1.9 & 35.42 & 78.4 & T73.12 & b & b & 34 & 25 \\
\hline 732 & 1350 & 40 & 16.69 & I7 & 12 & 74 & -54.4 & -65.92 & 42.5 & 108.5 & 6 & b & 29 & 21 \\
\hline 783 & 1450 & 10 & 76.98 & 37 & 32 & 100 & 30.6 & 87.08 & -1.5 & 29.3 & 249.2 & 480.56 & 69 & 51 \\
\hline 788 & 1450 & 5 & 16.66 & 38 & 33 & 818 & I7.7 & 63.86 & -11.9 & To.58 & 163.2 & 325.76 & 70 & 52 \\
\hline 788 & 1450 & 20 & 17.29 & 34 & 29 & 100 & 21.1 & 69.98 & -3.2 & 26.24 & b & 6 & 63 & 46 \\
\hline 788 & 1450 & 40 & 17.61 & 32 & 27 & 100 & 26.7 & 80.06 & 6.6 & 35.886 & 6 & b & 60 & 44 \\
\hline 843 & 1550 & 5 & 17.53 & 23 & 18 & 100 & 50.3 & 122.54 & 72.7 & 162.86 & b & $b$ & 41 & 30 \\
\hline 843 & 1550 & 10 & $17.8 \%$ & 19 & 14 & 75 & 42.3 & 108.14 & 95.5 & 203.9 & b & 5 & 32 & 24 \\
\hline 843 & 1550 & 20 & 18.20 & 31 & 26 & 75 & 58.2 & 136.76 & 46.5 & 115.7 & b & 6 & 57 & 42 \\
\hline 843 & $1550^{\circ}$ & 40 & T8.54 & 30 & 25 & 75 & 43.8 & 110.84 & 35.6 & $96.0 \%$ & 6 & b & 54 & 40 \\
\hline 899 & 1650 & 5 & 18.40 & 27 & 22 & 88 & 63.8 & 146.84 & 65.8 & 150.44 & b & 5 & 48 & 35 \\
\hline 899 & 1650 & 10 & 18.75 & 34 & 29 & 125 & 92.8 & 1999.04 & 60.8 & 141.44 & 5 & b & 64 & 47 \\
\hline 899 & 1650 & 20 & 19.11 & 28 & 23 & 75 & 51.8 & 125.24 & 47.2 & 116.96 & b & b & 52 & 38 \\
\hline 699 & $1650^{\circ}$ & 40 & 19.46 & 22 & 17 & 88 & 63. & 156.4 & 787.4 & 1899.32 & 6 & b & 40 & 29 \\
\hline
\end{tabular}

aW-Ab-weded

b Did not achieve 68J.

c Did not achieve $27 \mathrm{~J}$ in the trandition reglon. 
Table 6. Summary of Charpy impact analysis for weld 4, low-carbon FCA weld

\begin{tabular}{|c|c|c|c|c|c|c|c|c|c|c|c|c|c|c|}
\hline \multicolumn{2}{|c|}{ ANos Tunar } & NW TRI. & T.P. & $\boldsymbol{K}$ & b & $c$ & \multicolumn{2}{|c|}{20} & \multicolumn{2}{|c|}{$127 J$} & \multicolumn{2}{|c|}{600} & \multicolumn{2}{|c|}{$0: 5$} \\
\hline $\mathrm{PCl}$ & $\left({ }^{\prime} F\right)$ & (HAR) & $\left(\times 10^{-3}\right)$ & (J) & क) & $(10)$ & Fes & $(f)$ & $7 \mathrm{C}$ & $(6)$ & $7 \mathrm{CI}$ & $7(n)$ & का & (II-Ib) \\
\hline XW & AW & $\mathrm{AW}$ & 0 & 40 & 35 & 67 & -7. & 19.6 & 33.6 & -28.48 & 64.7 & 178.46 & 75 & 56 \\
\hline 621 & 1150 & 3 & 14.04 & 45 & 40 & 58 & T0.8 & 51.44 & -17.3 & 8.86 & 74.8 & 118.07 & 85 & 63 \\
\hline 621 & 1150 & 10 & 14.31 & 7t & 42 & 45 & T1.8 & 533.24 & -11.3 & Tा.66 & 37.7 & 99.866 & 888 & 65 \\
\hline 621 & 1150 & 20 & 14.58 & 48 & 43 & 45 & 8.3 & 48.74 & -14.7 & 5.54 & 32.8 & 91.05 & 80 & 67 \\
\hline 621 & TI50 & $40^{-}$ & 14.65 & ST & 46 & 4 & 4.8 & 20.64 & -20.7 & 75.26 & 225 & 7.6 & 97 & $M$ \\
\hline 677 & 1250 & 5 & 14.91 & 51 & 46 & 53 & 3. & 37.4 & -27.2 & -16.96 & 23.7 & 74.66 & 97 & 7 \\
\hline 677 & 1250 & 10 & T5.20 & 53 & 48 & $\$ 0$ & 3.8 & 38.84 & -20.7 & -5.26 & T6.3 & $613 x$ & 102 & 75 \\
\hline $6 \pi$ & 1250 & 20 & 15.48 & 60 & 55 & 33 & T6.2 & 61.16 & 6.3 & 20.66 & 21.3 & 70.34 & $\pi 14$ & 84 \\
\hline 677 & 1250 & 40 & 15.77 & 70 & 65 & 46 & 25.7 & 78.26 & -10.9 & 12.38 & $2 \pi .5$ & 76.1 & I34 & 99 \\
\hline 732 & 1350 & 5 & 15.78 & 46 & 41 & 61 & -5.9 & 21.36 & 36.5 & 36.7 & 29.9 & 85.82 & 87 & 64 \\
\hline 732 & 1350 & 70 & 16.09 & 53 & 48 & 81 & 9. & 48.2 & -40.2 & 70.36 & 35 & 95 & TOI & 75 \\
\hline 732 & 1350 & 20 & 16.39 & S1 & 46 & 62 & 8.1 & T7.42 & 4 & -47.2 & 15.7 & 60.26 & 87 & 72 \\
\hline $7 / 32$ & 1350 & 40 & 16.69 & 34 & 49 & 64 & 3 & 37.4 & 37.2 & 34.95 & 21.2 & 70.16 & 104 & 77 \\
\hline 788 & 1450 & 5 & 16.66 & 58 & 53 & 75 & 12. & 53.6 & 38.1 & 36.58 & 26.5 & 79.7 & $\Pi 1$ & 82 \\
\hline 788 & 1450 & 10 & 16.98 & 54 & 49 & 75 & 9. & 46.2 & 37 & 34.6 & 32.2 & 89.983 & $T 02$ & 75 \\
\hline 788 & 1450 & 20 & 17.29 & 60 & 55 & 75 & 20.2 & 68.36 & 31.7 & -25.06 & 31.4 & 88.52 & 115 & 85 \\
\hline 788 & 1450 & 40 & 17.61 & 63 & 58 & 75 & T8.5 & 65.3 & 36.1 & 32.98 & 24.7 & 76.46 & T2I & 90 \\
\hline 843 & 1550 & 5 & 17.53 & 70 & 65 & 50 & .7 & 33.26 & 39.2 & 38.56 & -1.1 & 30.02 & 136 & 100 \\
\hline 843 & $1550^{\circ}$ & 70 & 17.86 & 71 & 66 & 50 & 1.7 & 35.06 & -38.4 & -37.12 & -0.3 & 31.46 & 136 & 100 \\
\hline 843 & 1550 & 20 & 18.20 & 94 & 89 & 50 & 17.9 & 64.22 & -31.2 & -24.16 & 2.6 & 36.68 & 184 & 136 \\
\hline 843 & 1550 & $40^{\circ}$ & 18.54 & 91 & 86 & 750 & 3.5 & 38.3 & -21.4 & 77.92 & .10 & 14 & 176 & 130 \\
\hline 899 & 1650 & 5 & $\mathrm{~T} 8.40$ & III & 106 & 100 & 71.3 & 160.34 & 36.6 & 33.88 & 28.2 & 82.76 & 217 & 100 \\
\hline 899 & 1650 & 10 & 18.75 & 129 & 124 & 125 & 100. & 212 & 45.7 & -50.26 & 32.6 & 90.68 & 253 & 187 \\
\hline 899 & 1650 & 20 & 19.11 & 130 & 125 & 125 & 100. & 212 & -46.1 & -50.98 & 32 & 60.6 & 255 & 188 \\
\hline 899 & 1650 & 40 & 19.46 & T18 & TI3 & 100 & 50. & 122 & 61.6 & -78.7 & 2.3 & 36.14 & 232 & $T \pi$ \\
\hline
\end{tabular}

a $A$ - As-medod 


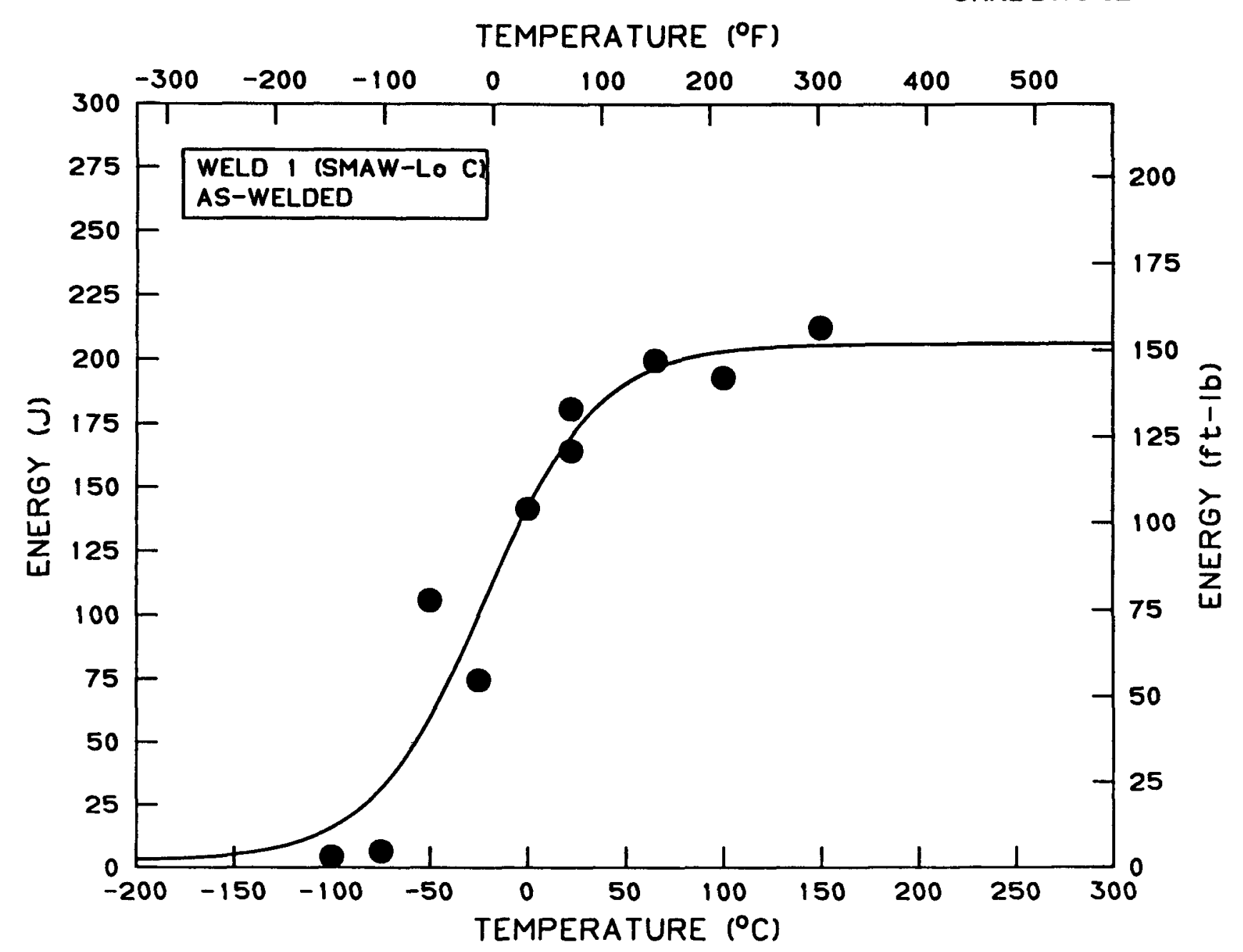

Figure 14. CVN energy versus test temperature for weld 1, a low-carbon SMA weld in the aswelded condition. The solid curve is the resulting fit of the data to a hyperbolic tangent function. 


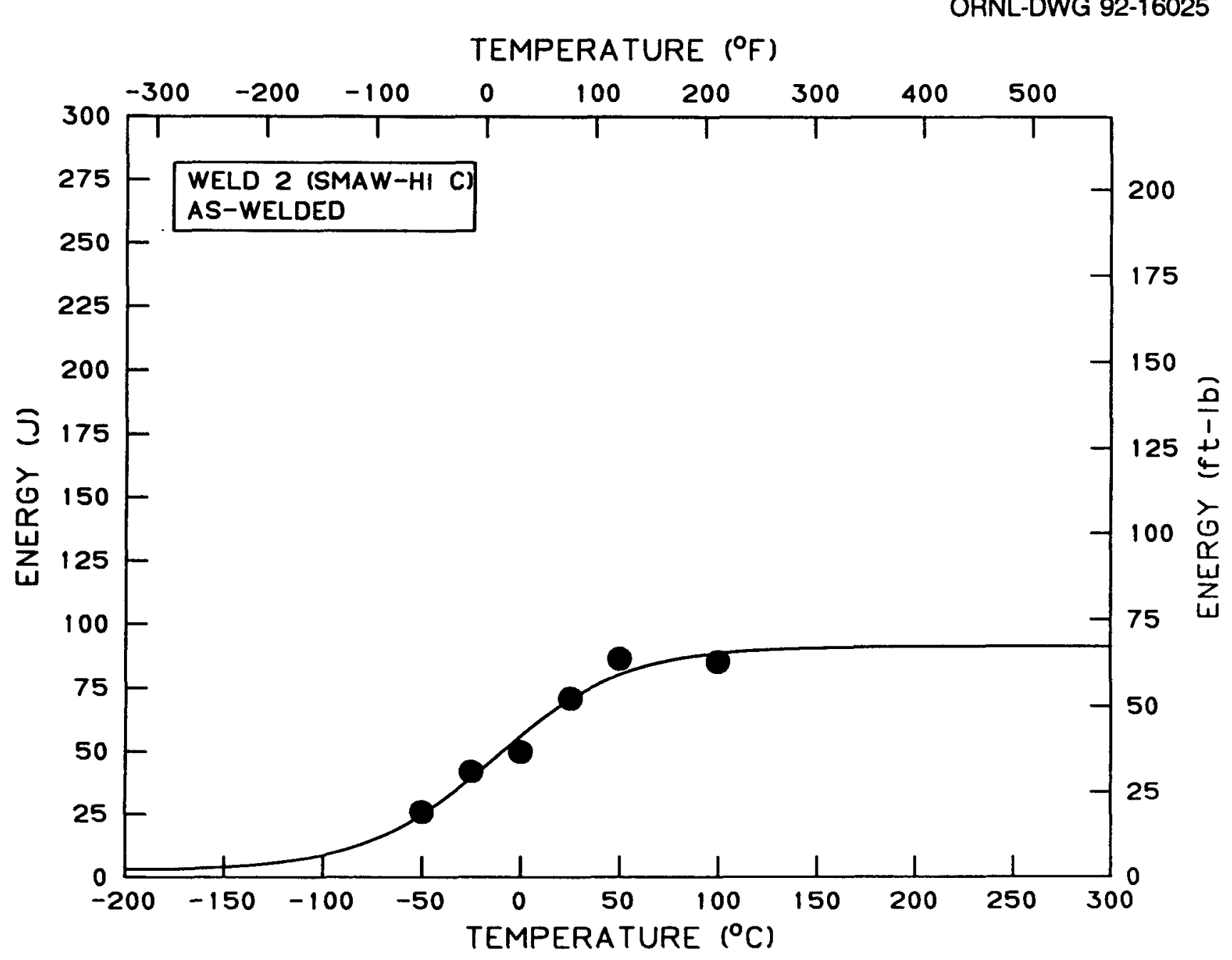

Figure 15. CVN energy versus test temperature for weld 2, a high-carbon SMA weld in the aswelded condition. The solid curve is the resulting fit of the data to a hyperbolic tangent function. 
N

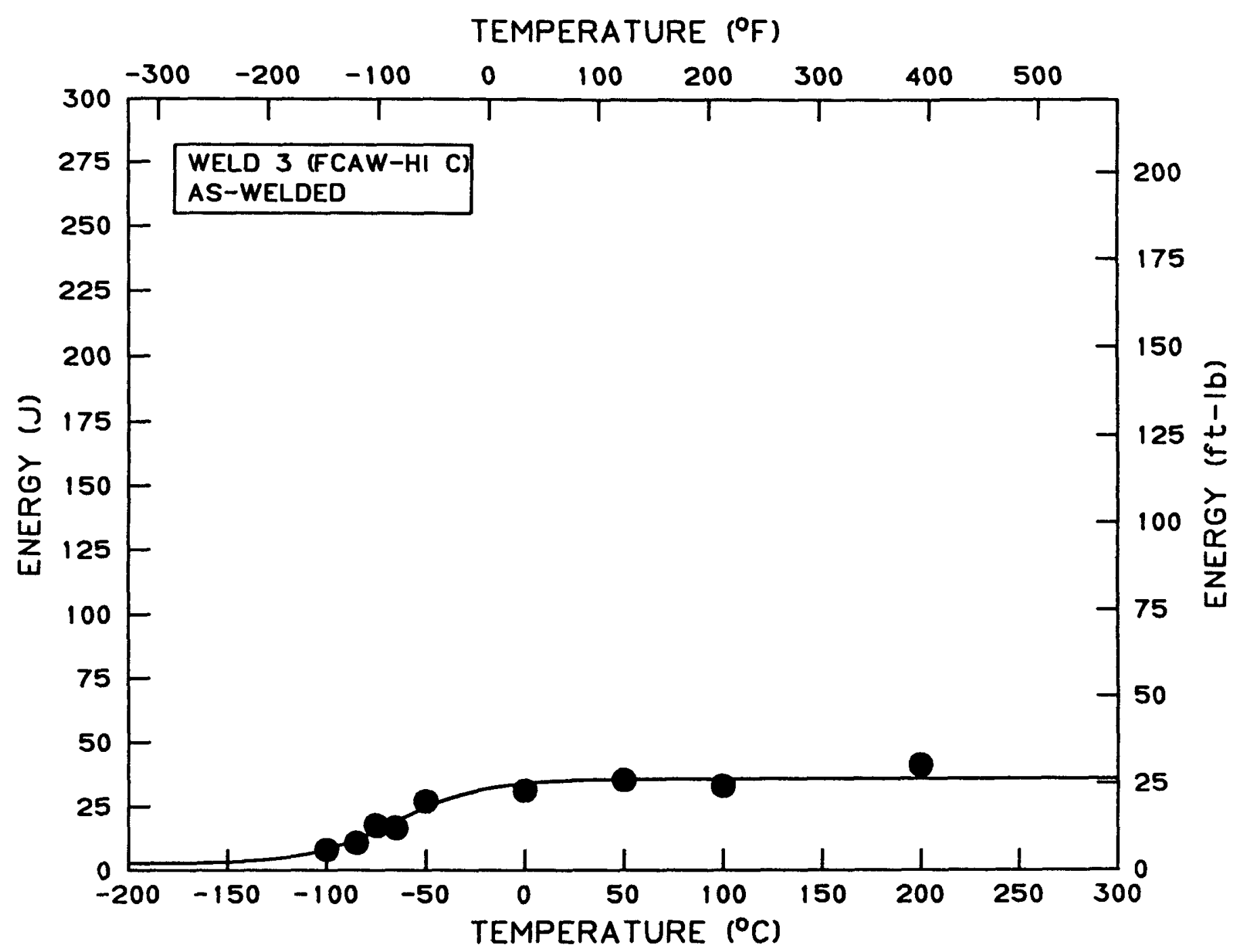

Figure 16. CVN energy versus test temperature for weld 3, a high-carbon FCA weld in the as-welded condition. The solid curve is the resulting fit of the data to a hyperbolic tangent function. 


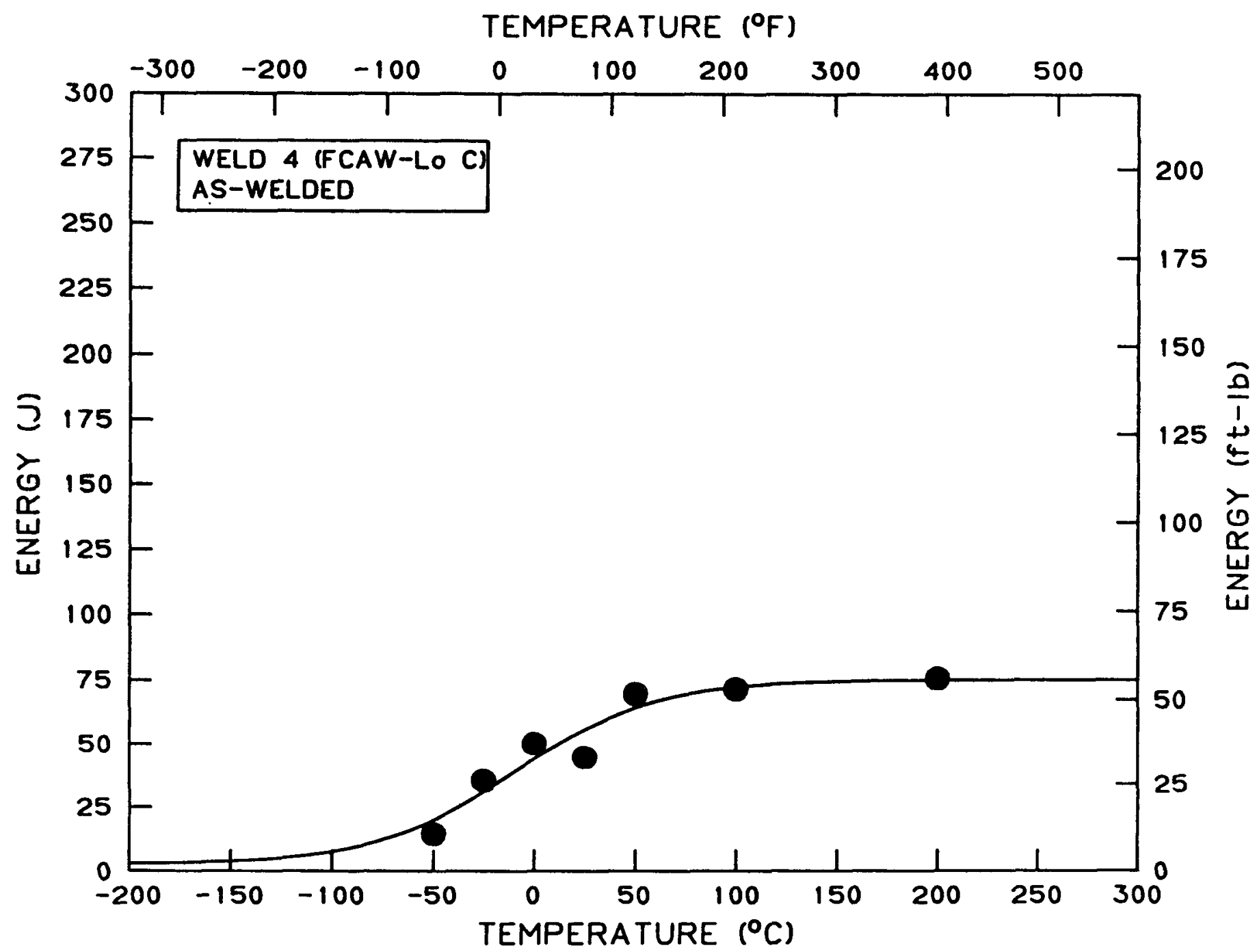

Figure 17. CVN energy versus test temperature for weld 4, a low-carbon FCA weld in the as-welded condition. The solid curve is the resulting fit of the data to a hyperbolic tangent function. 


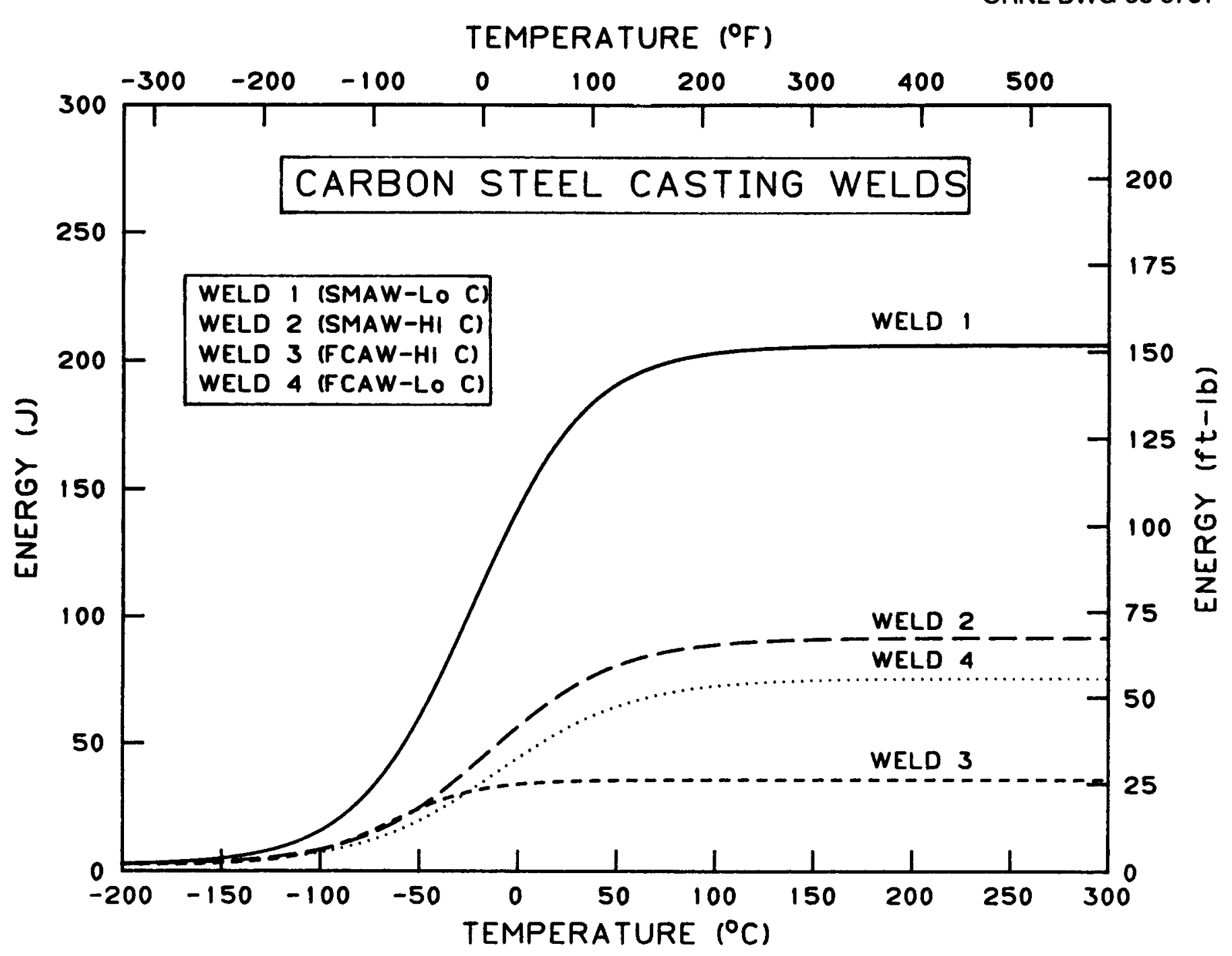

Figure 18. Comparison of hyperbolic tangent curve fits to CVN energy versus test temperature data for welds 1 through 4 in the as-welded condition. 
ORNL-DWG 93-5782

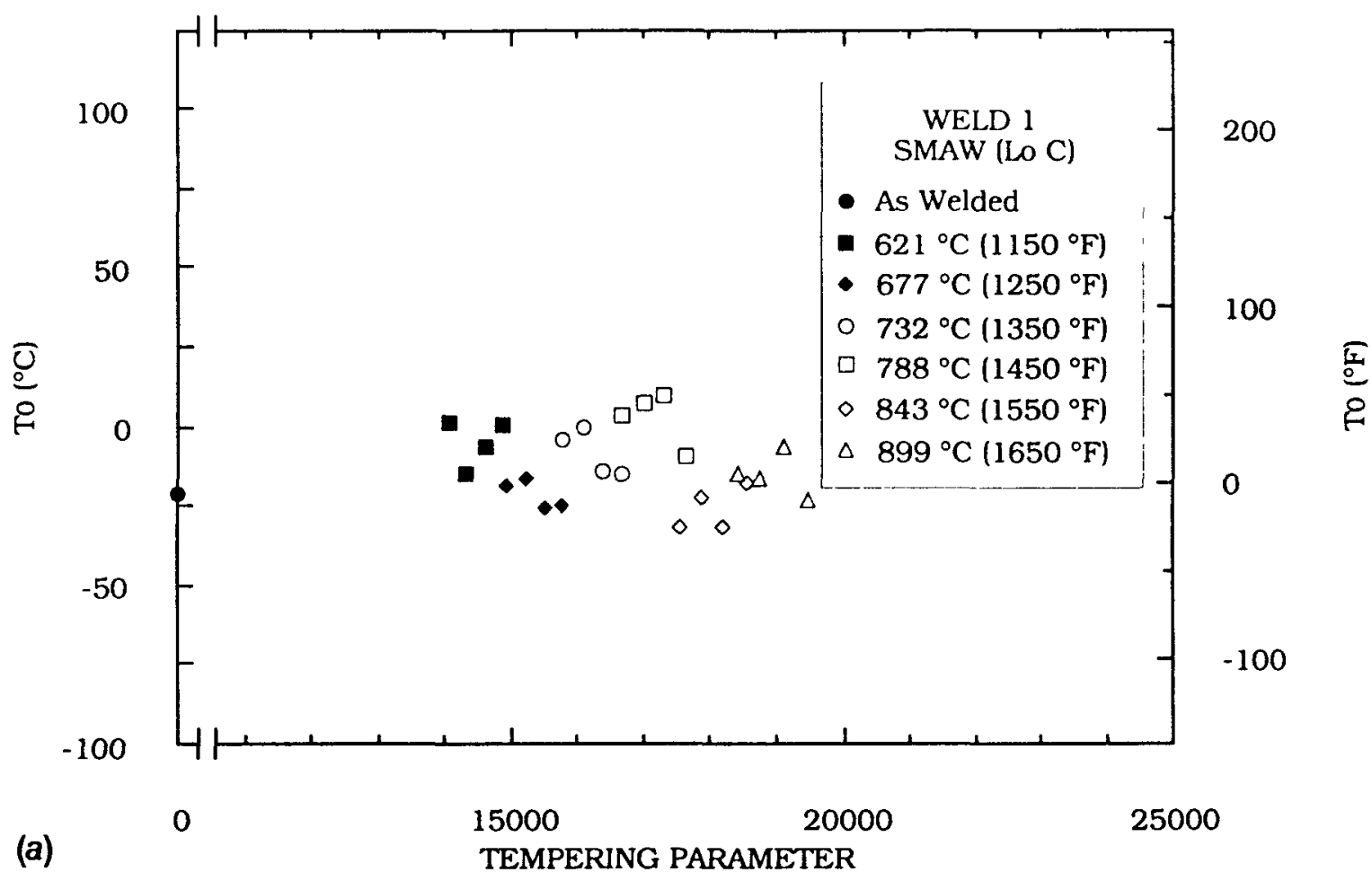

ORNL-DWG 93-5783

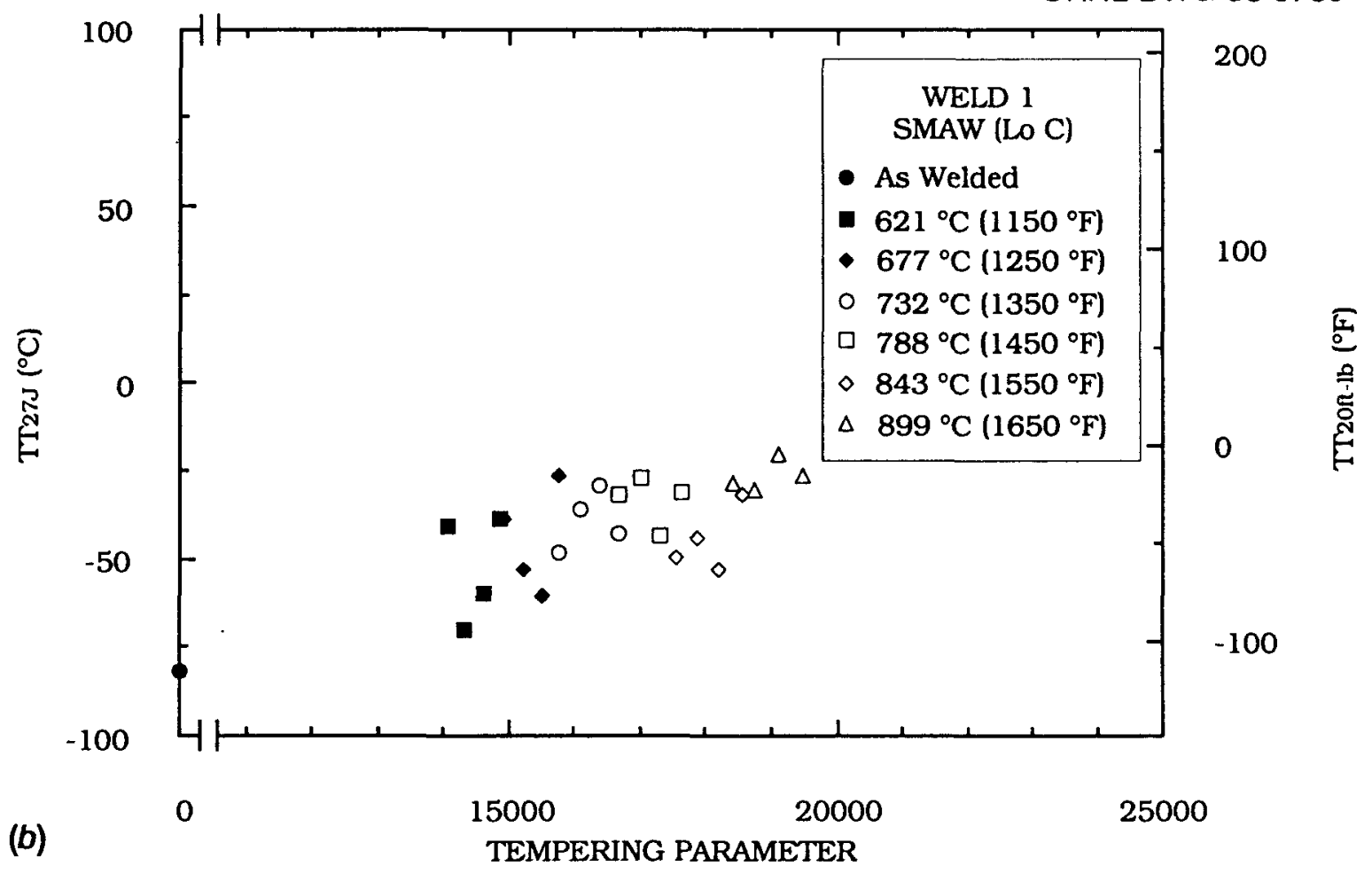

Figure 19. Effects of PWHT on CVN impact behavior showing (a) $T_{0},(b) \Pi_{27 \mathrm{~J}}$, (c) $T_{6 B N}$, and $(d)$ USE versus the $T P, T^{\star}(15+\log t)$, for weld 1 , a lowcarbon SMA weld. The equation shown in $(d)$ is the result of a linear regression to the USE data at PWHT temperatures of $677^{\circ} \mathrm{C}\left(1250^{\circ} \mathrm{F}\right)$ and lower, while the solid line shows the resulting fit. 
ORNL-DWG 93-5784

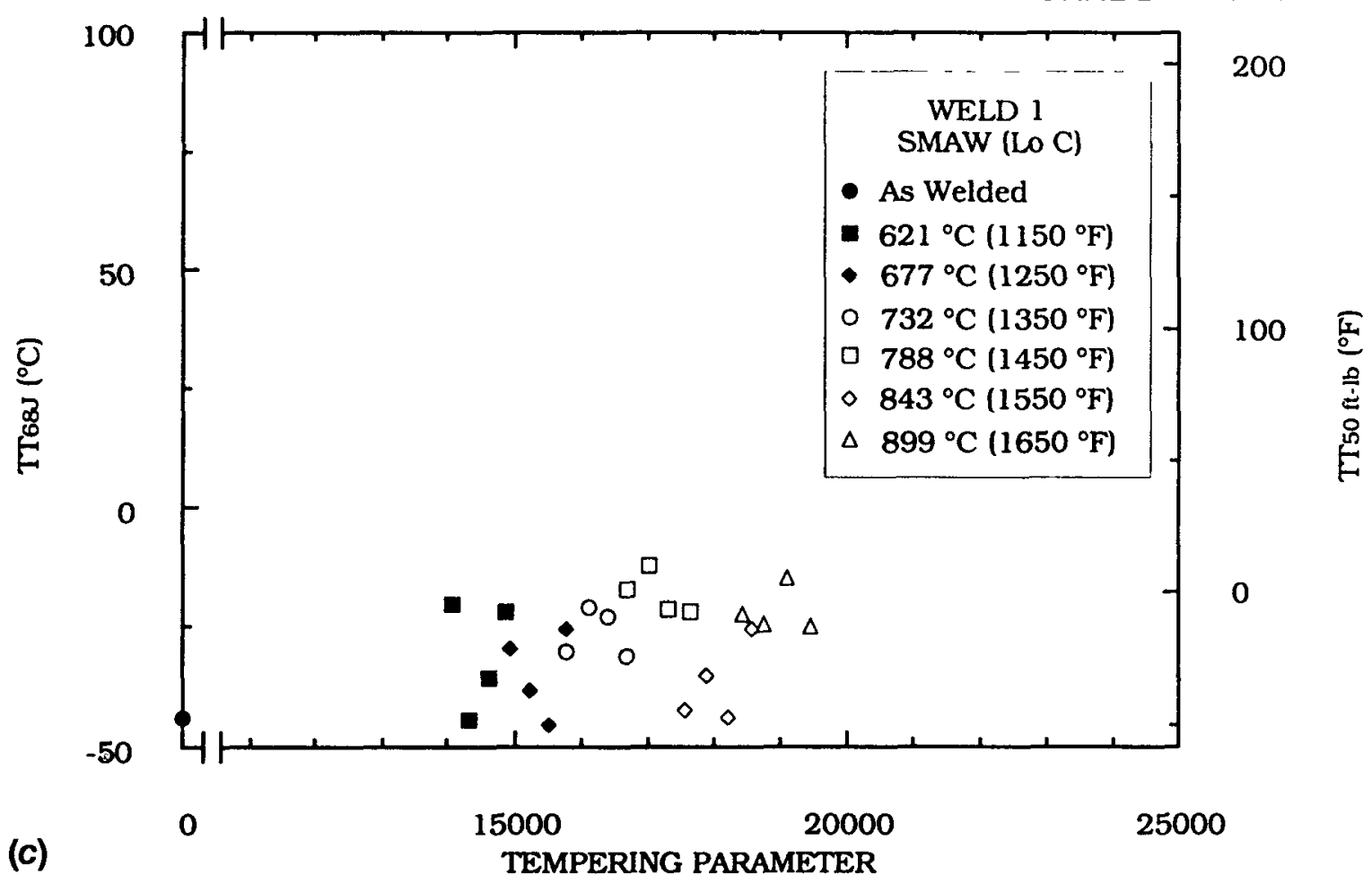

ORNL-DWG 93-5785

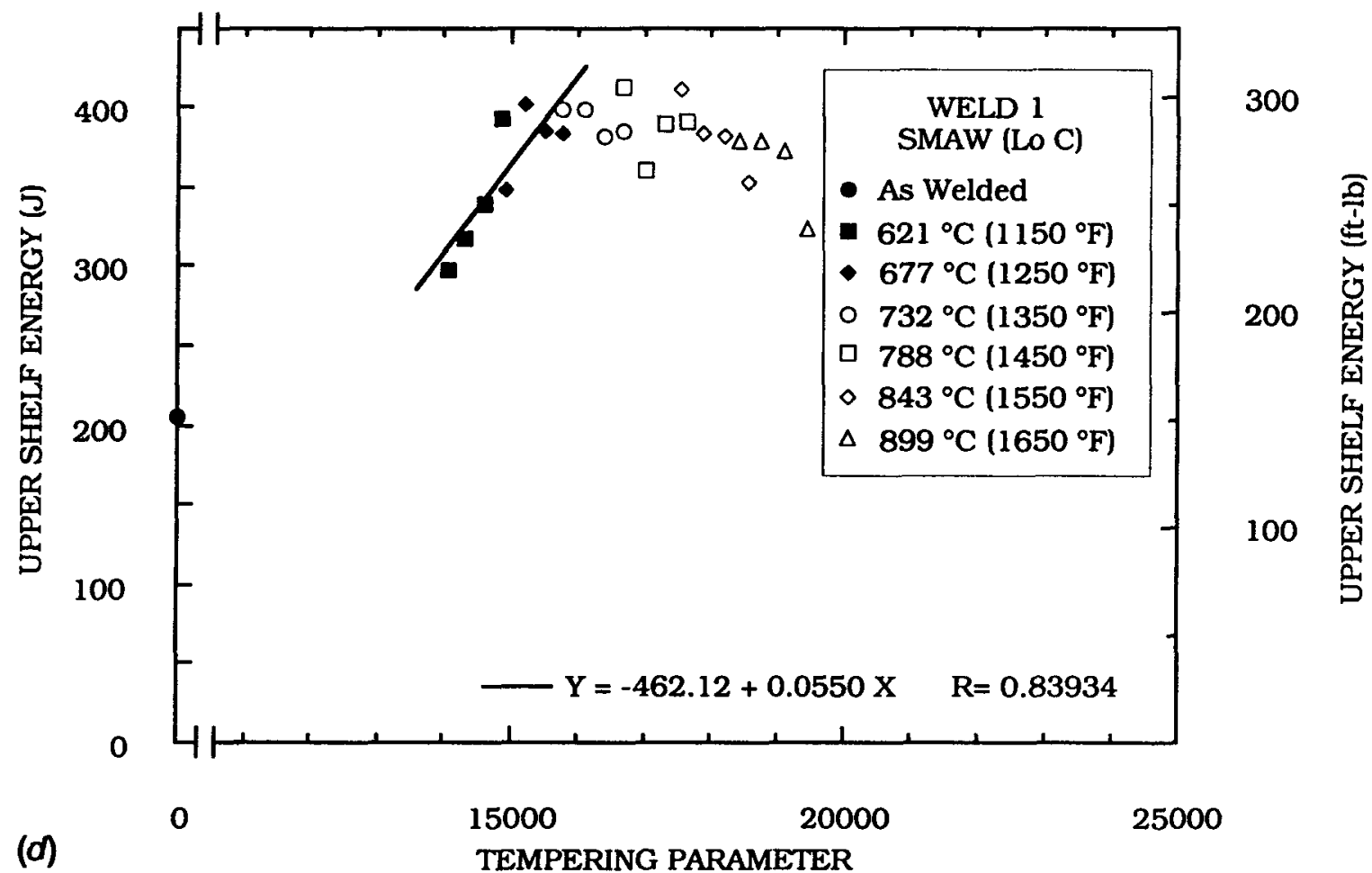

Figure 19. Continued. 
ORNL-DWG 93-5786

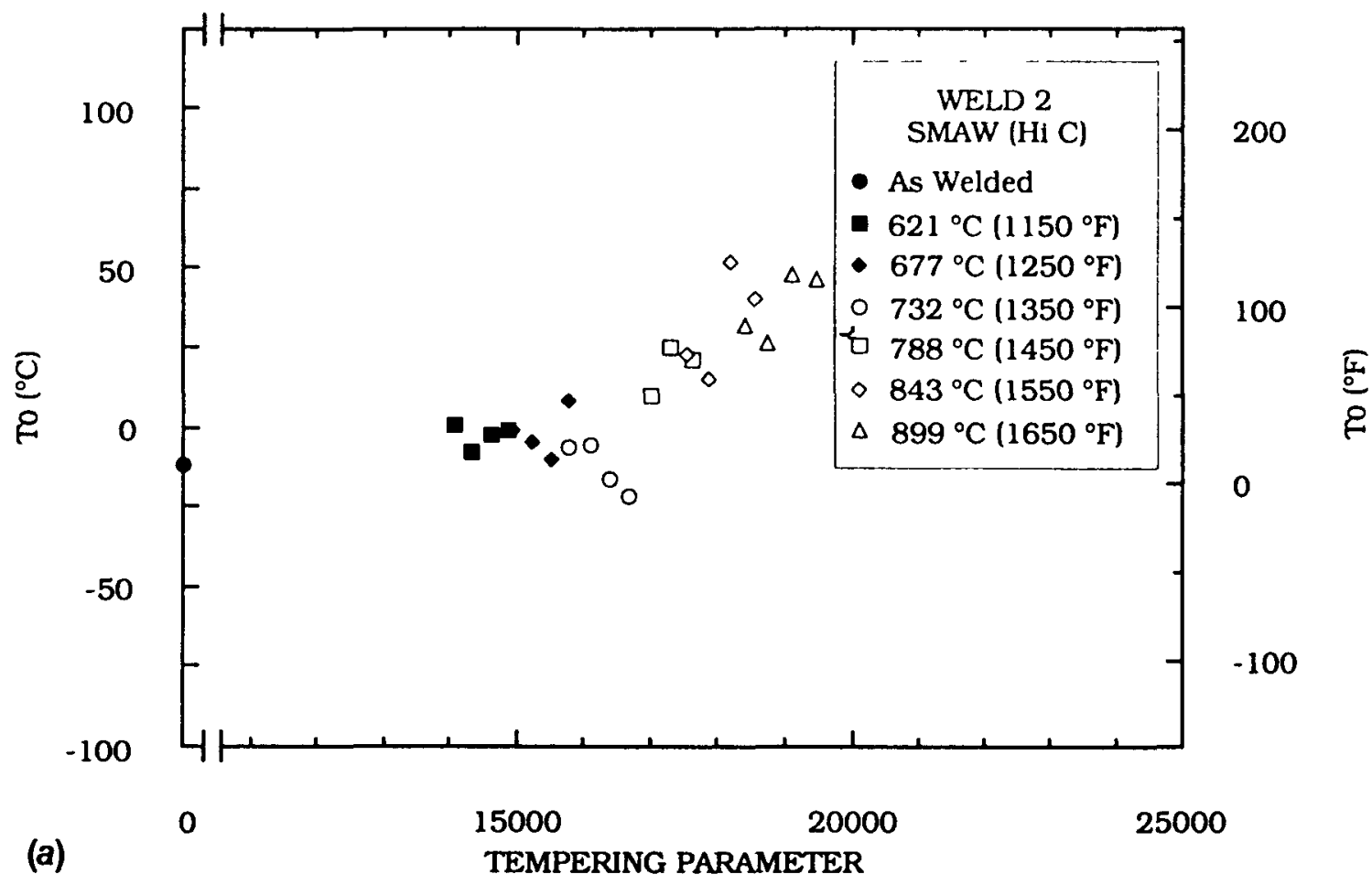

ORNL-DWG 93-5787

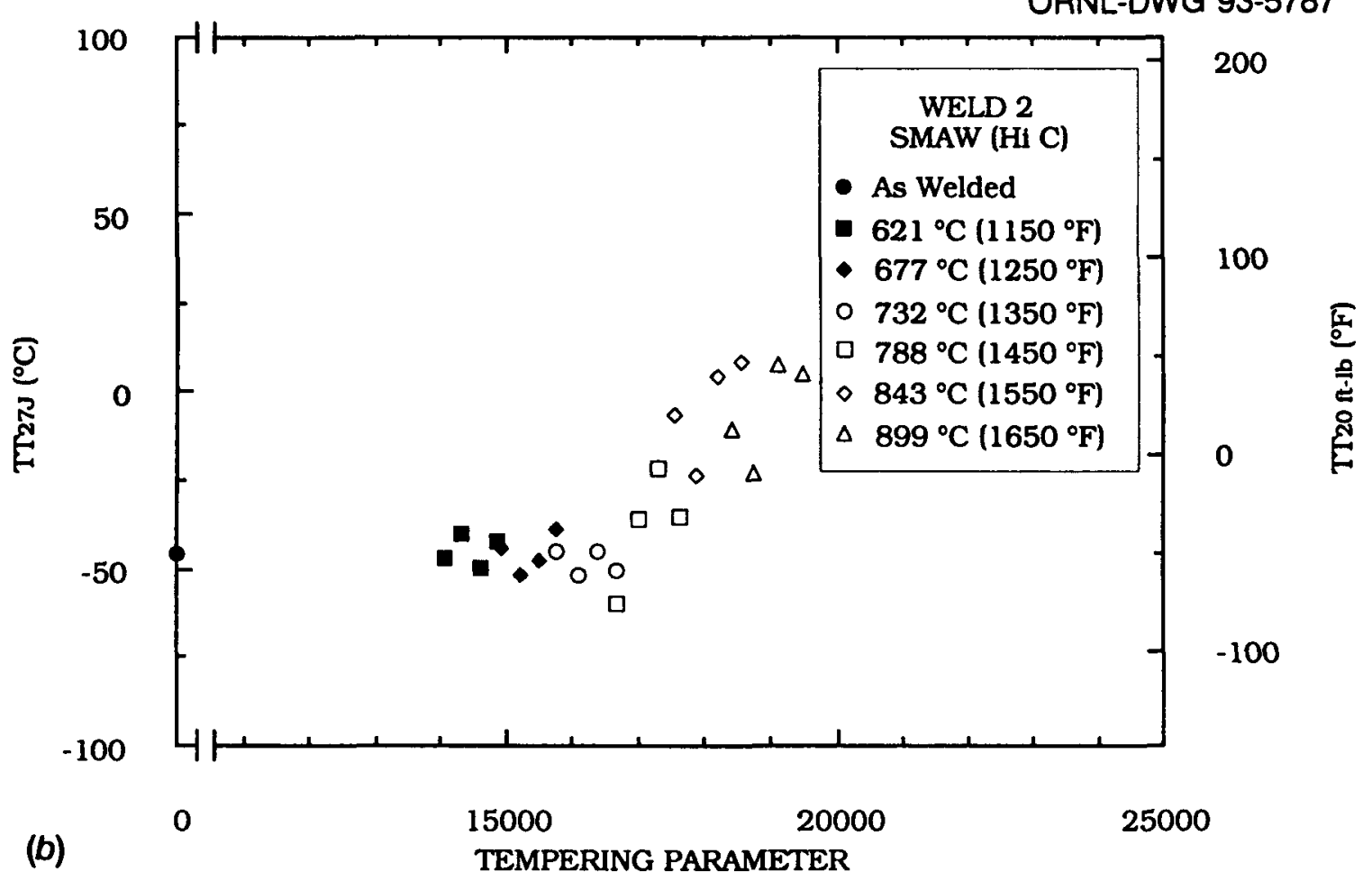

Figure 20. Effects of PWHT on CVN impact behavior showing (a) $T_{0},(b) \Pi_{27 J}$ (c) $T_{68,}$, and (d) USE versus the TP, $T^{\star}(15+\log t)$, for weld 2, a highcarbon SMA weld. The equation shown in ( $d$ ) is the result of a linear regression to the USE data at PWHT temperatures of $677^{\circ} \mathrm{C}\left(1250^{\circ} \mathrm{F}\right)$ and lower, while the solid line shows the resulting fit. 
ORNL-DWG 93-5788

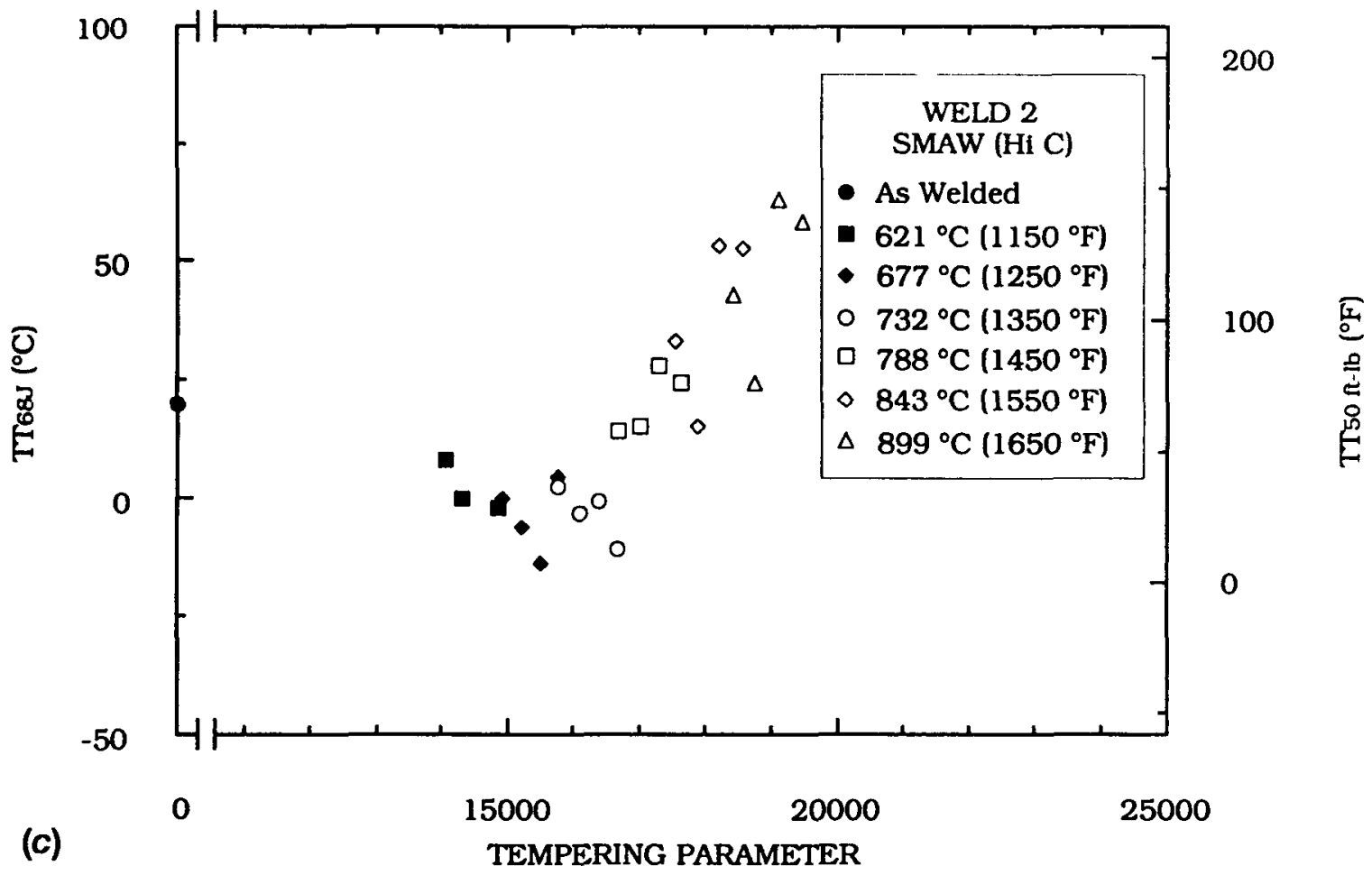

ORNL-DWG 93-5789

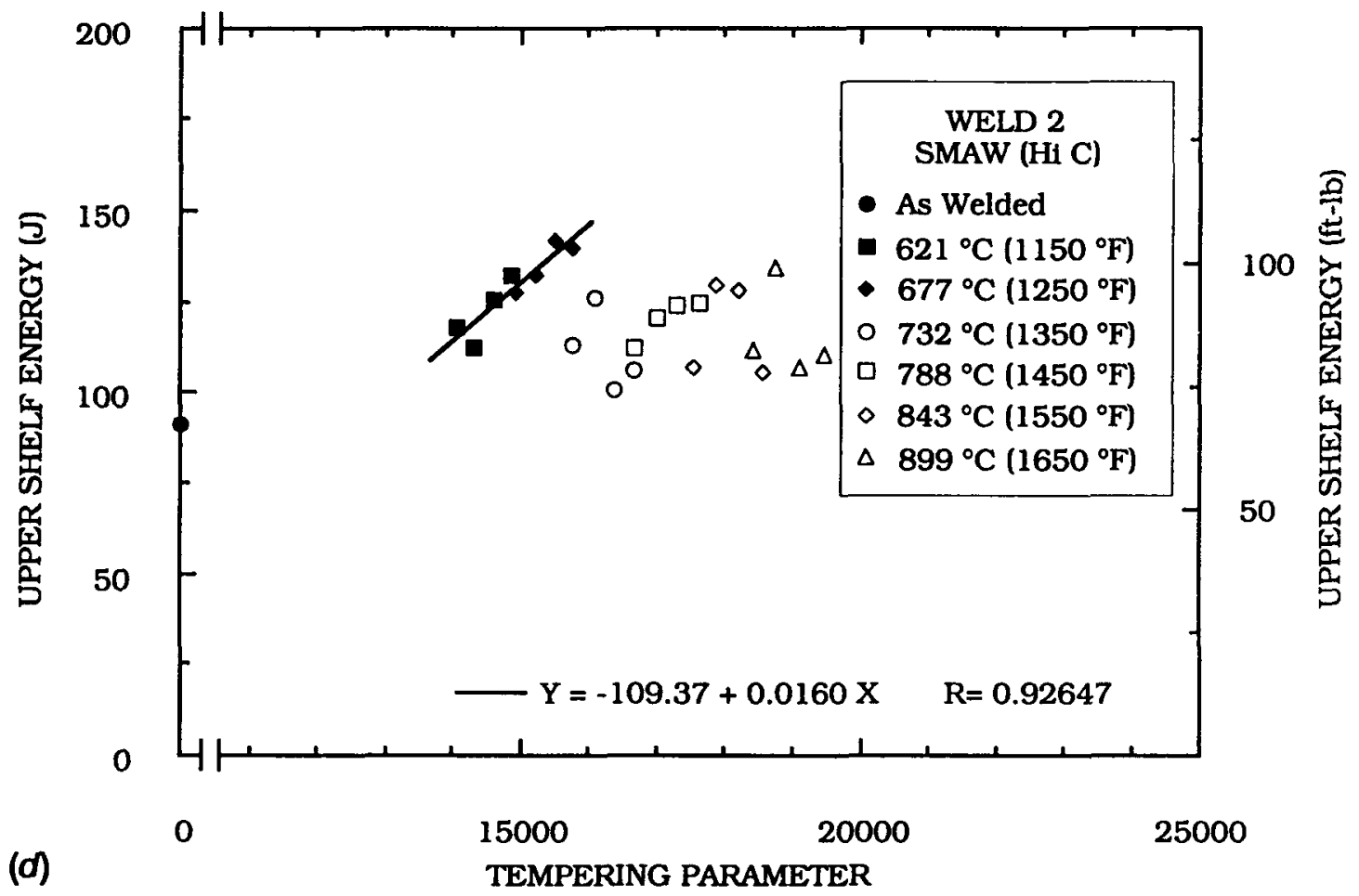

Figure 20. Continued. 
ORNL-DWG 93-5790

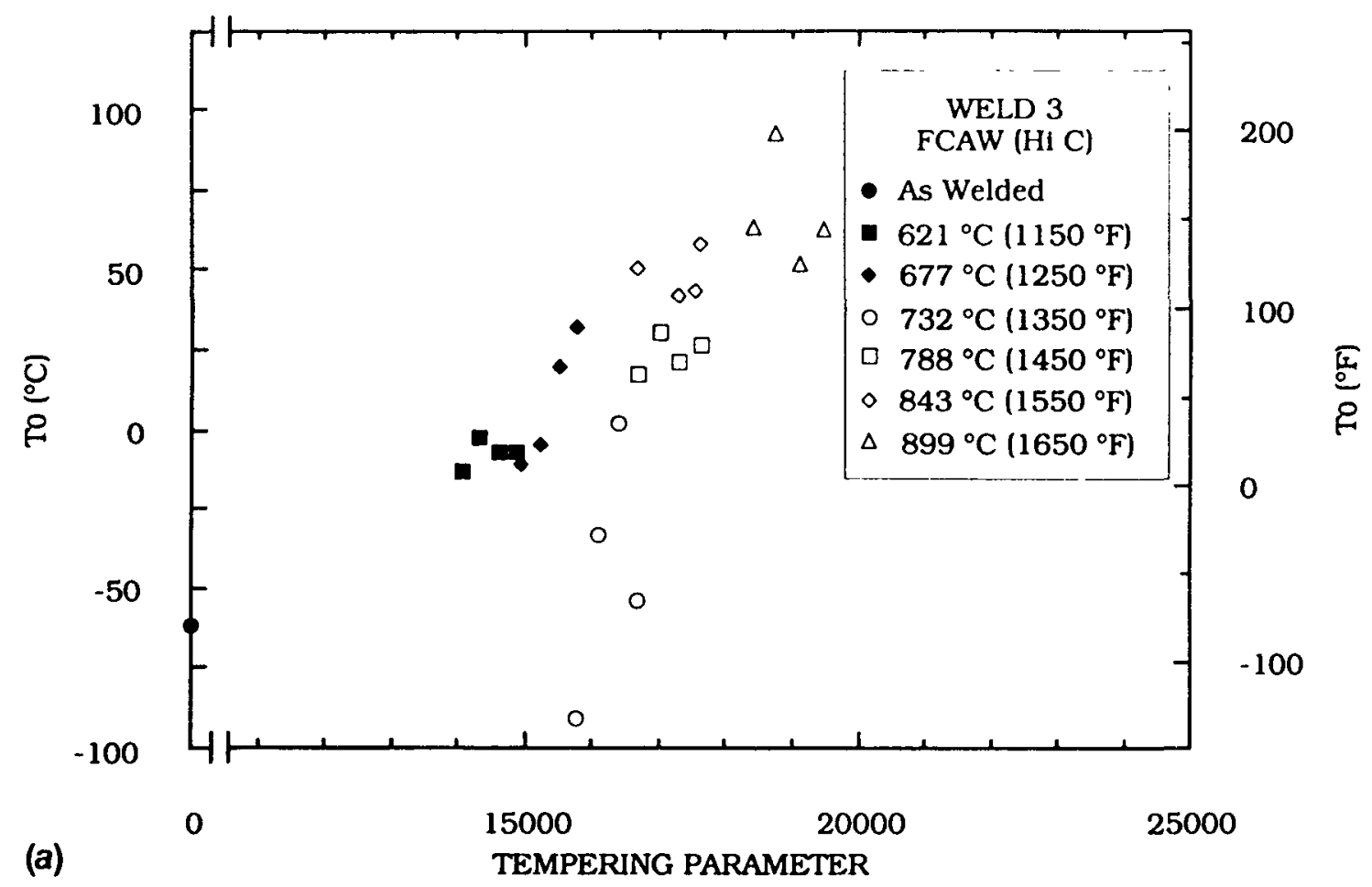

ORNL-DWG 93-5791

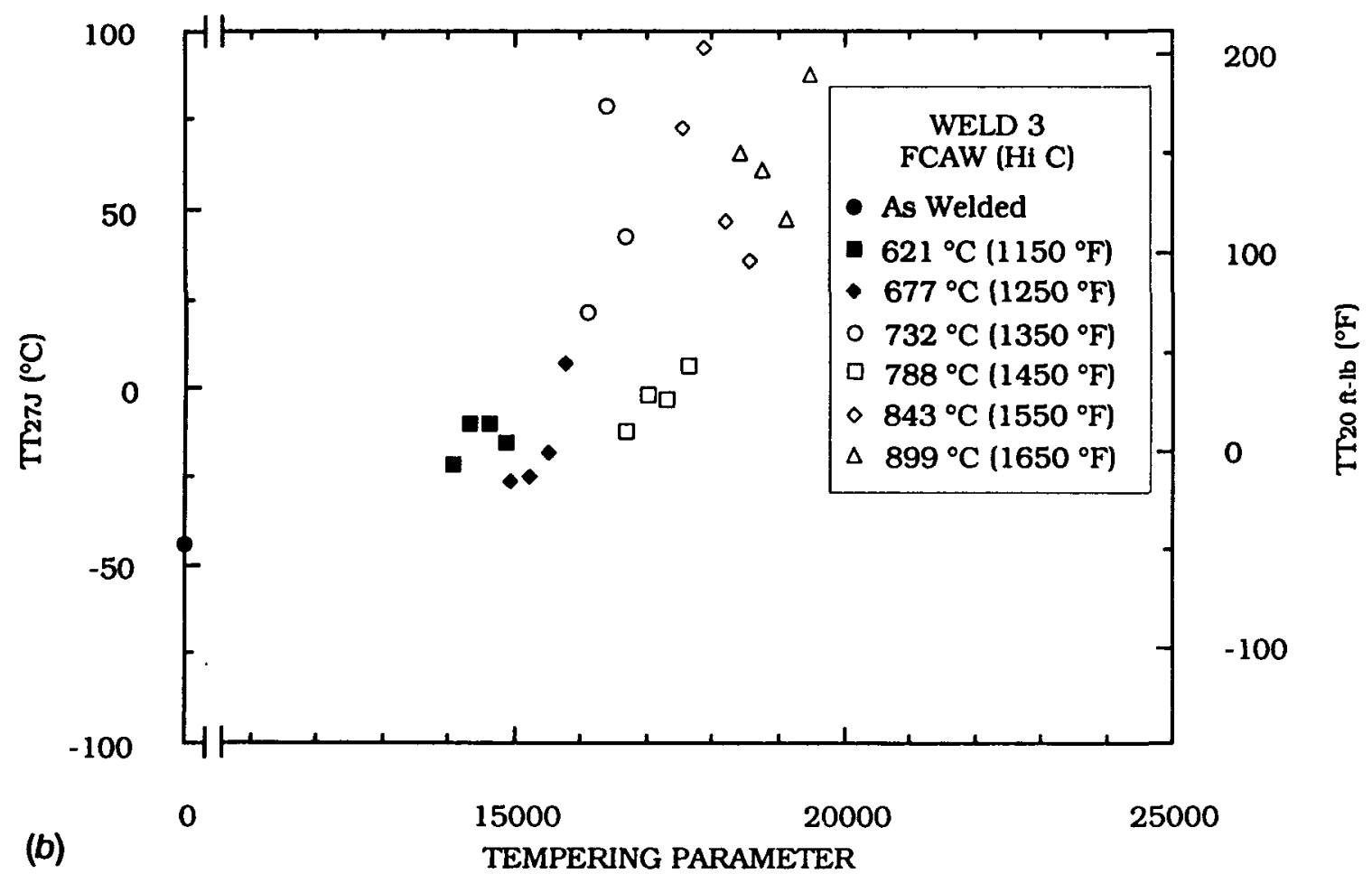

Figure 21. Effects of PWHT on CVN impact behavior showing (a) $T_{0},(b) \Pi_{27,}$, and (c) USE versus the TP, $T^{*}(15+\log t)$, for weld 3 , a high-carbon FCA weld. The equation shown in (c) is the result of a linear regression to the USE data at PWHT temperatures of $677^{\circ} \mathrm{C}\left(1250^{\circ} \mathrm{F}\right)$ and lower, while the solid line shows the resulting fit. 
ORNL-DWG 93-5792

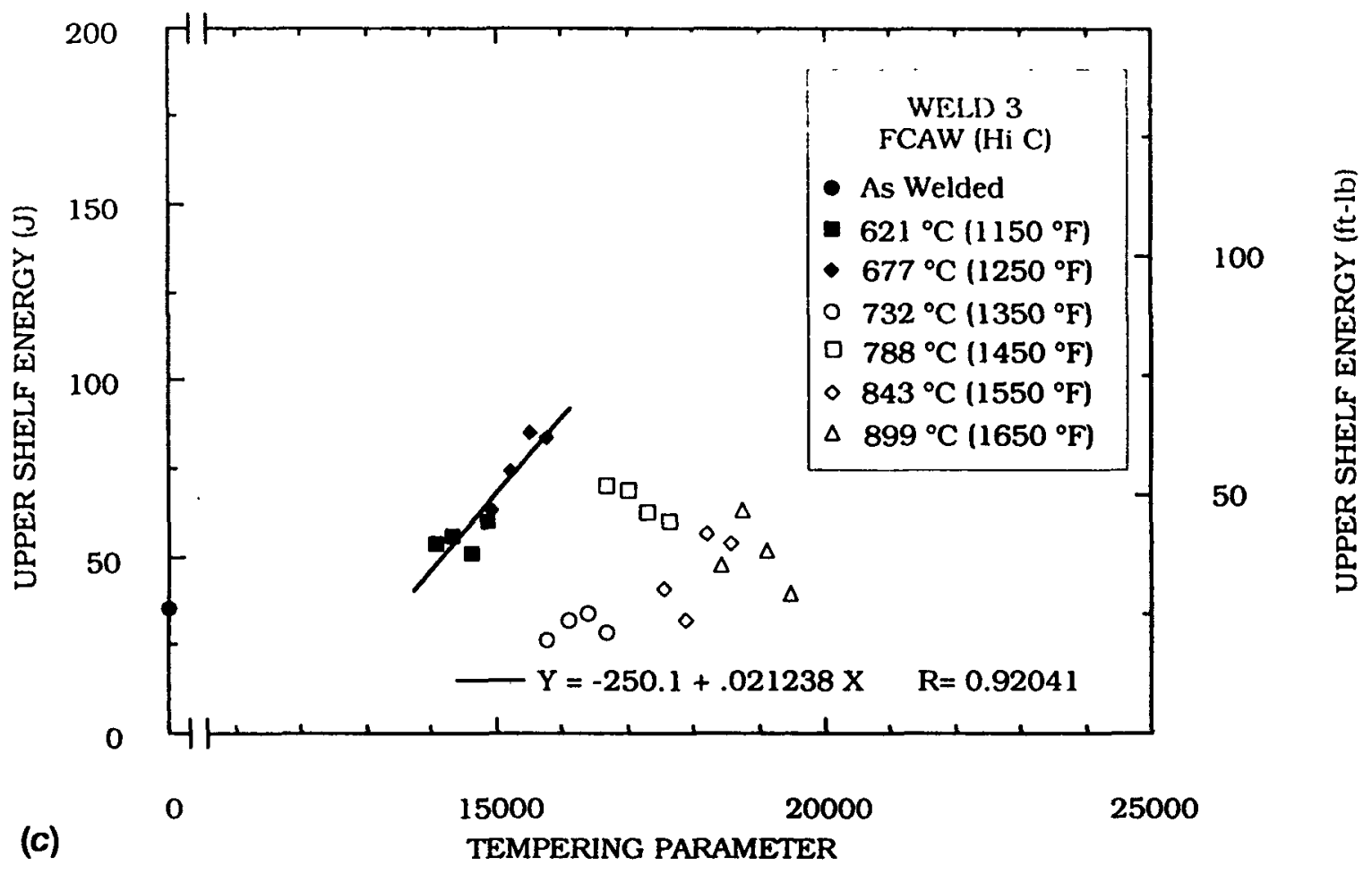

Figure 21. Continued. 
ORNL-OWG 93-5793

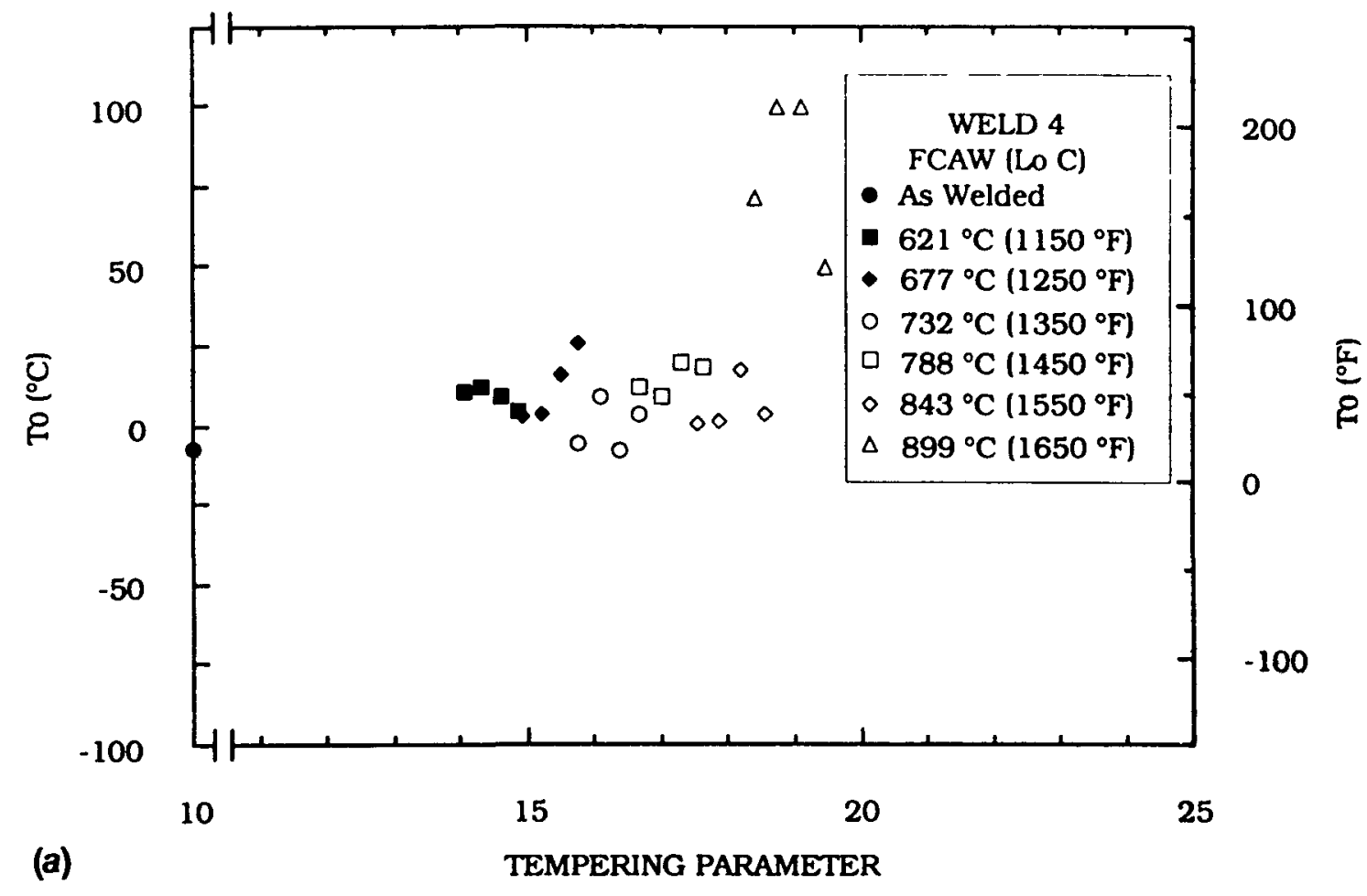

ORNL-DWG 93-5794

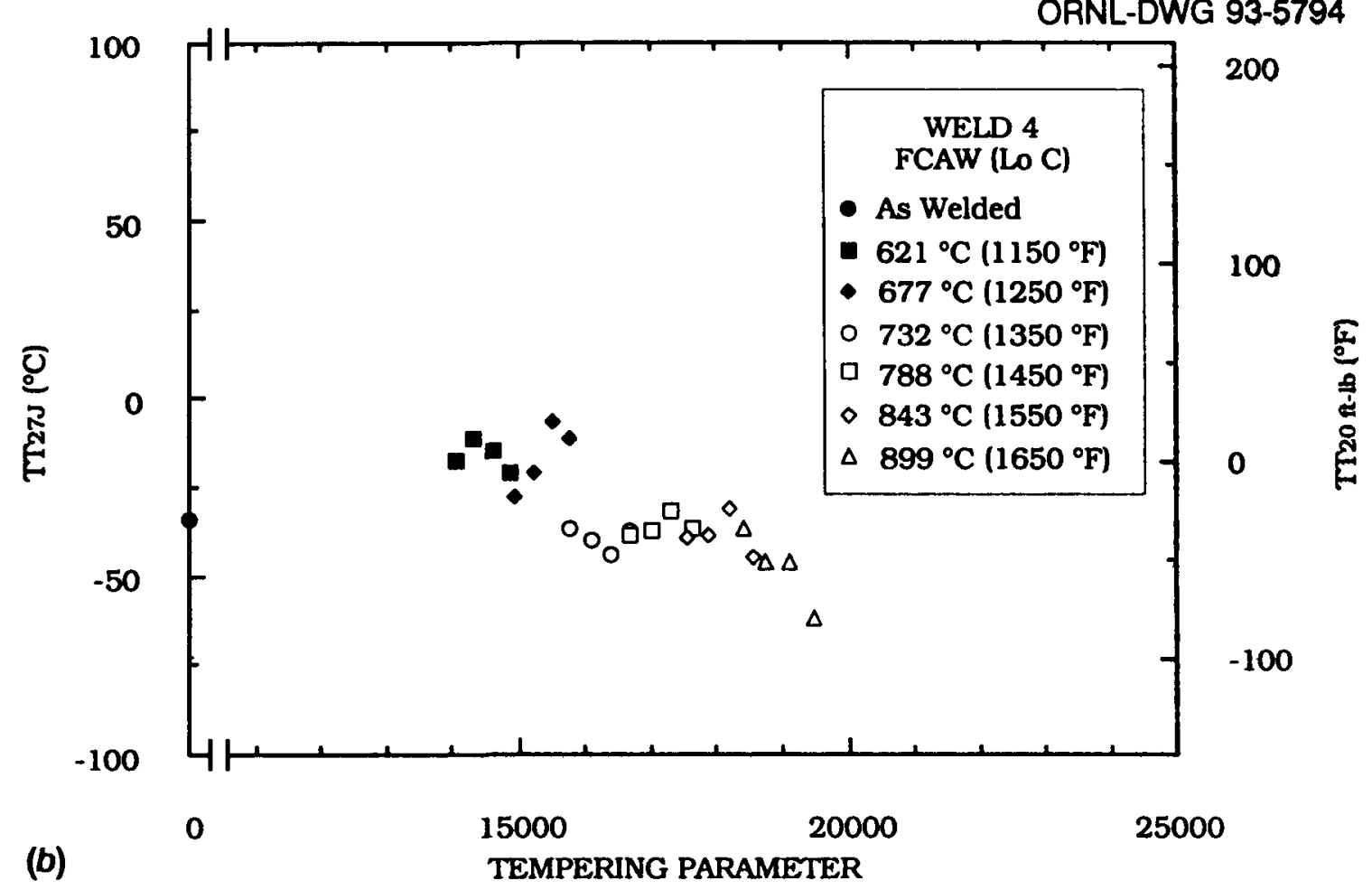

Figure 22. Effects of PWHT on CVN impact behavior showing (a) $T_{o}$ (b) $\Pi_{27,}$ (c) $\pi_{68,}$, and $(d)$ USE versus the TP, $T^{*}(15+\log t)$, for weld 4 , a low-carbon FCA weld. The equation shown in $(d)$ is the result of a linear regression to the USE data at PWHT temperatures of $677^{\circ} \mathrm{C}$ $\left(1250^{\circ} \mathrm{F}\right)$ and lower, while the solid line shows the resulting fit. 
ORNL-DWG 93-5795

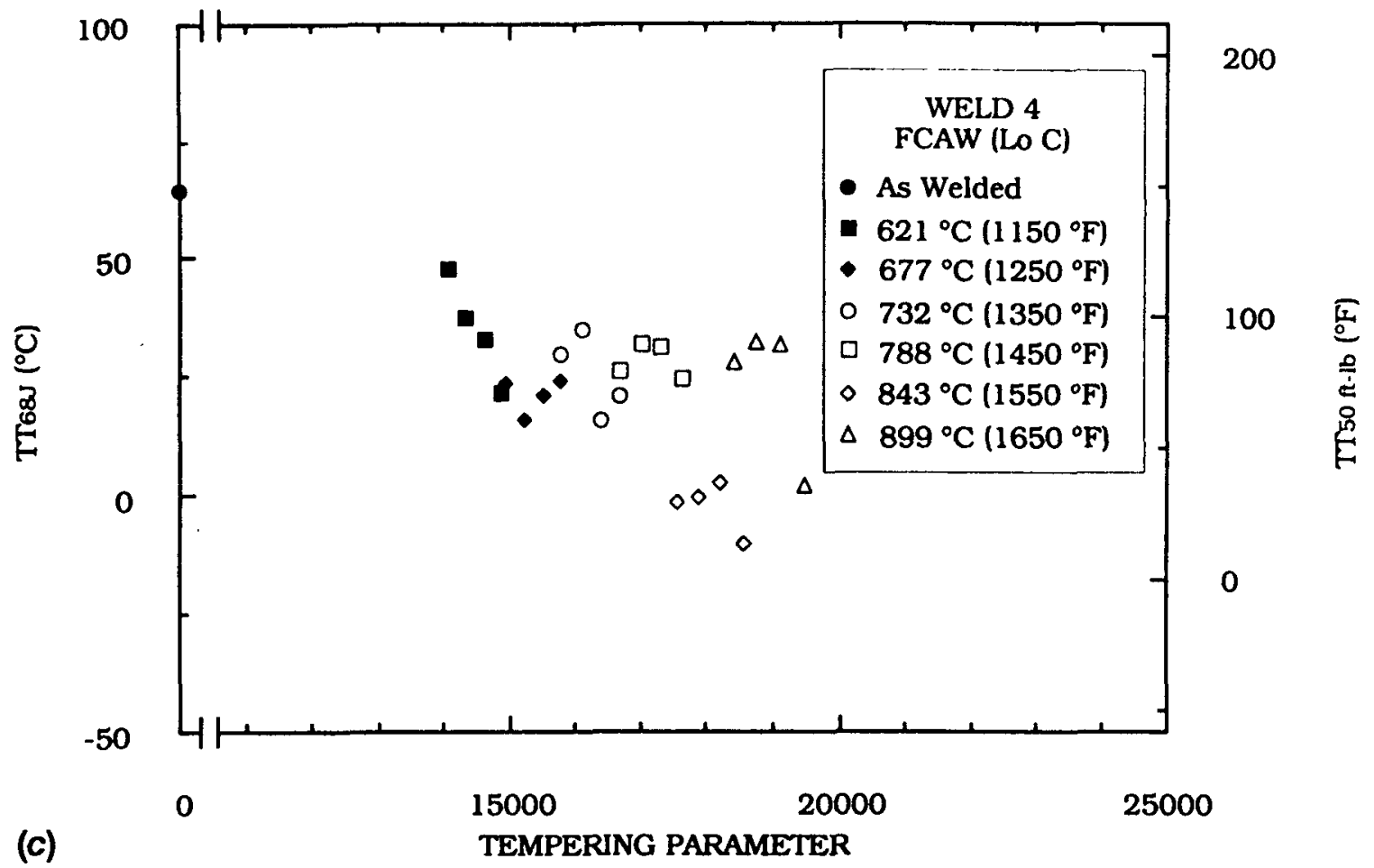

ORNL-DWG 93-5796

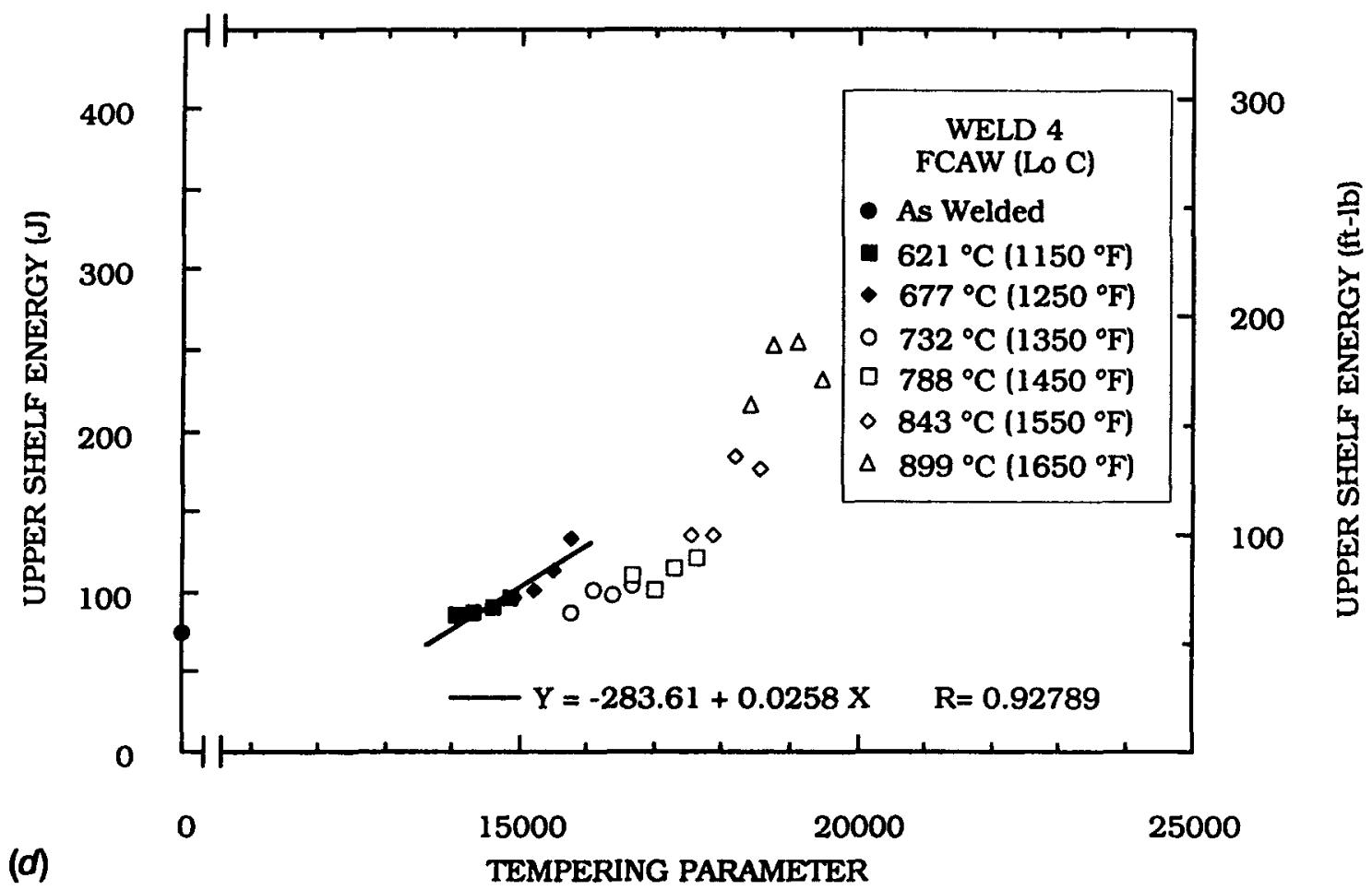

Figure 22. Continued. 


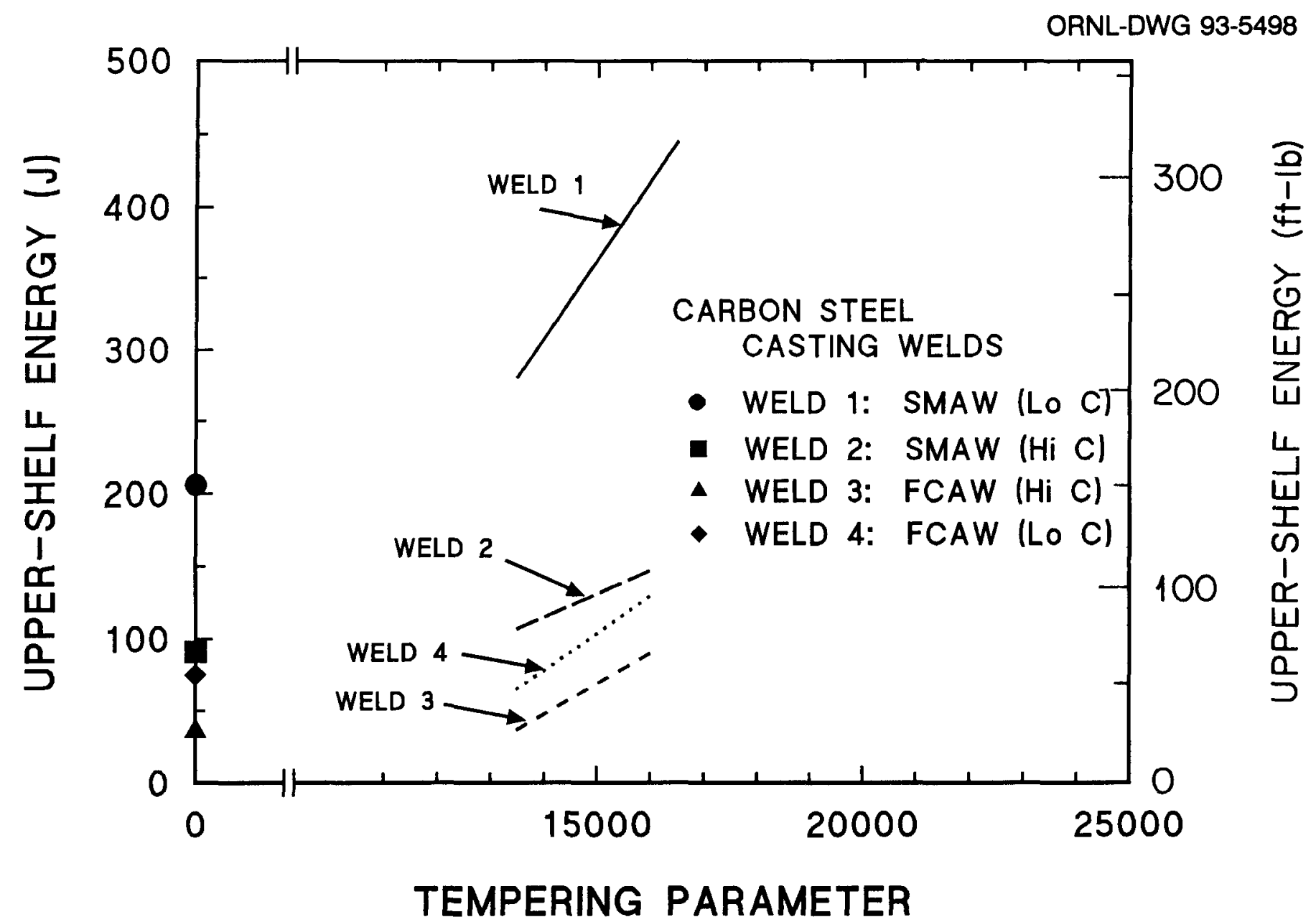

Figure 23. Comparison of linear regression curves to USE results versus the TP, $T^{\star}(15+\log t)$, for welds 1 through 4. 
$92-1396-1$

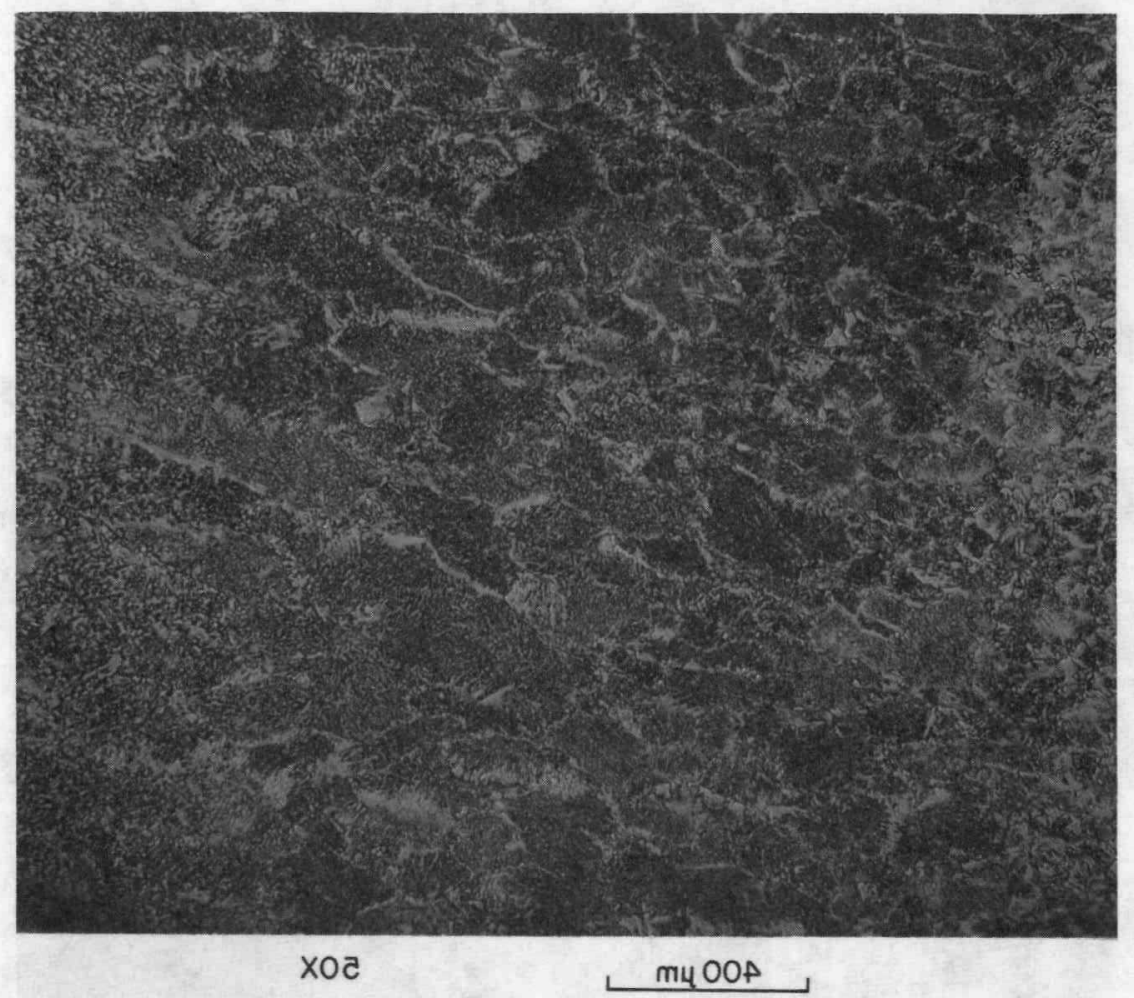

$92-1400-1$

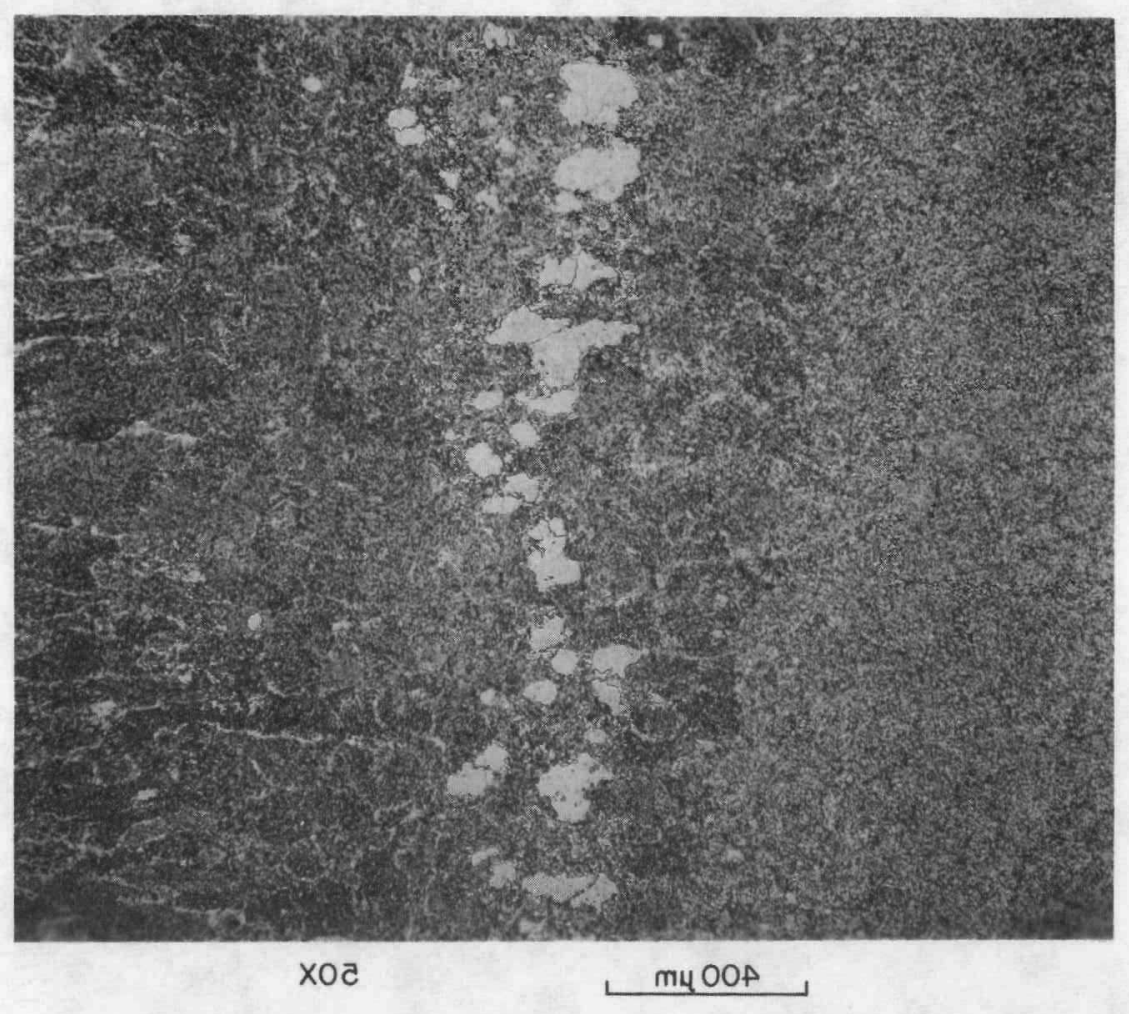

Figure 24. Micrographs of (a) through (d), welds 1 through 4, respectively, in the as-welded condition. 
92-1403-1

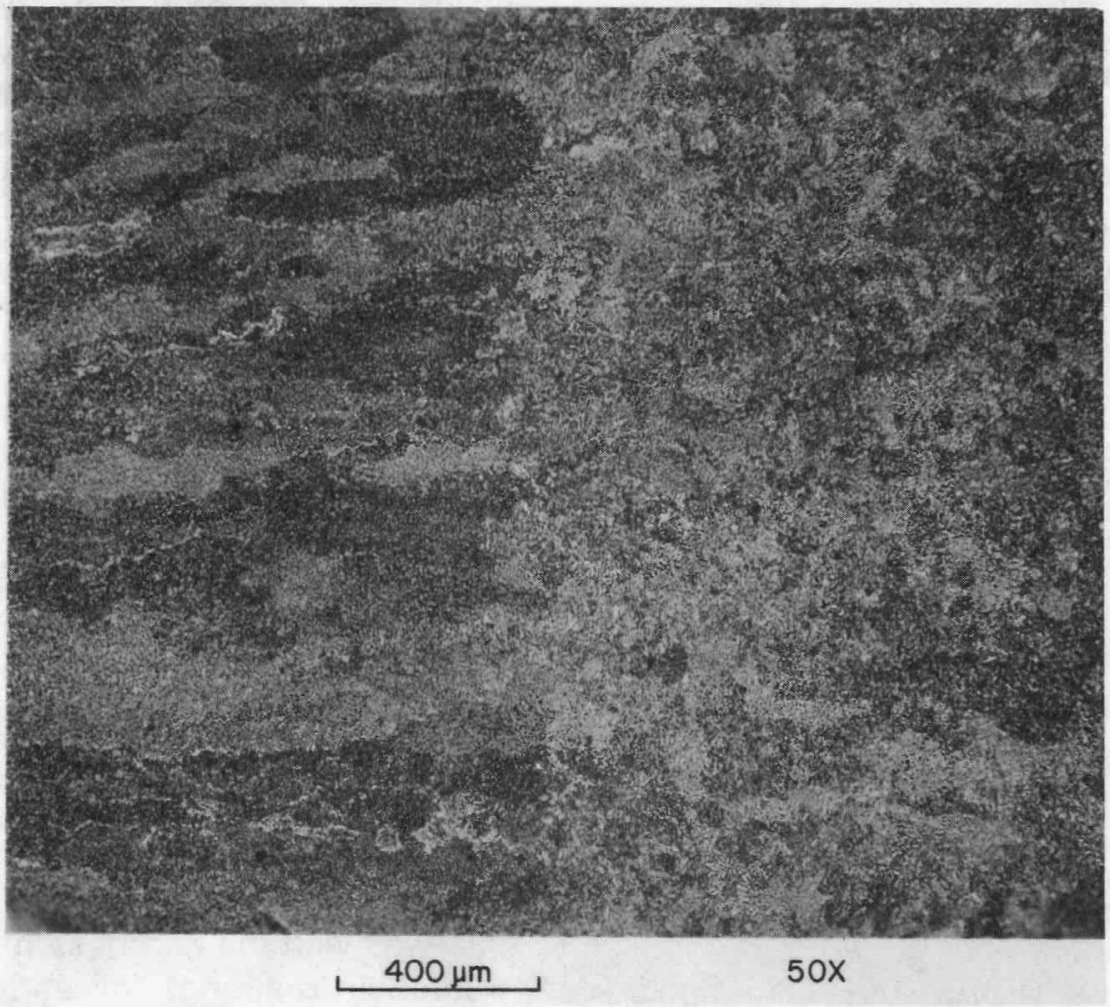

(c)

92-1406-1

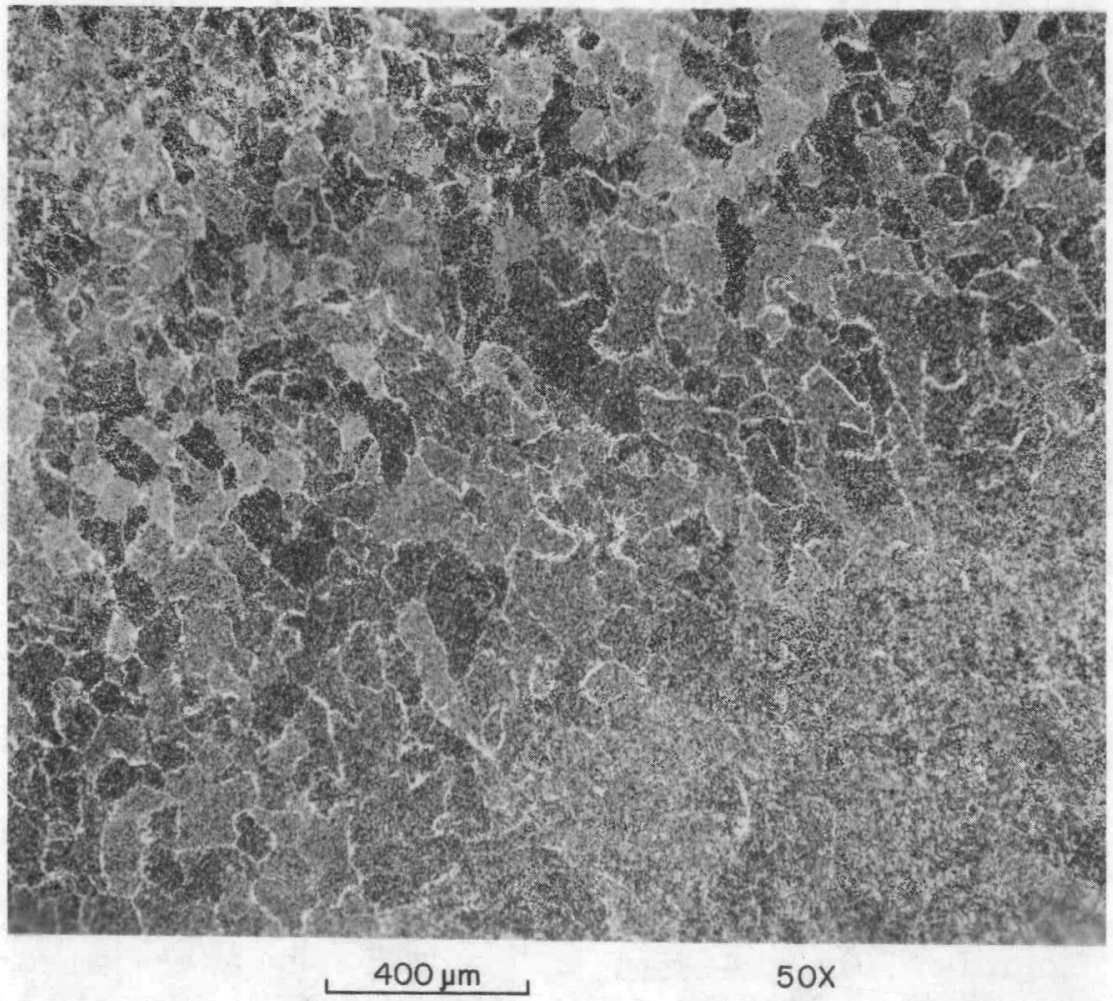

Figure 24. Continued. 
the as-welded condition. They consist primarily of acicular ferrite and/or bainite, and the low-carbon welds ( 1 and 4) exhibit some proeutectoid ferrite at the prior austenite grain boundaries. Only weld 2 revealed existence of some blocky ferrite. Heat treatments of $1350^{\circ} \mathrm{F}$ and higher [Figures 25(a) through (c)] result in essentially complete transformation, and longer times at $1350^{\circ} \mathrm{F}$ do not coarsen the transformed structure [Figure 25(b) versus (c)]. Longer times at the highest temperature investigated $\left(1650^{\circ} \mathrm{F}\right)$ cause substantial grain growth [Figures 26(a) through (e)], as noted by comparing Figure 26(a) with (b). The fully annealed structures consist of equiaxed ferrite, and varying amounts of pearlite, depending on carbon content. More detailed examination of the microstructures regarding inclusion content, carbide evolution, etc., was outside the scope of the current program.

\section{Summary and Conclusions}

Two SMA and two FCA welds (low- and highcarbon versions of each) were fabricated in 101.6-mm-thick (4-in.) A 36 hot-rolled steel plate. All four welds were given simulated PWHTs at temperatures from 621 to $899^{\circ} \mathrm{C}$ $\left(1150\right.$ to $\left.1650^{\circ} \mathrm{F}\right)$ in increments of $56^{\circ} \mathrm{C}\left(100^{\circ} \mathrm{F}\right)$ and for times of $5,10,20$, and $40 \mathrm{~h}$ at each temperature. Hardness, CVN, and tensile tests were conducted on the welds in the as-welded condition and all the heat-treated conditions. The CVN tests were conducted to obtain results over the brittle-ductile transition range and fitted with hyperbolic tangent curves. The hardness, yield and ultimate strength, CVN transition temperatures, and USE were plotted versus a TP for comparison. For the hardness and tensile strength data, the results for PWHTs at 621 and $677^{\circ} \mathrm{C}\left(1150\right.$ and $\left.1250^{\circ} \mathrm{F}\right)$ were fitted with linear regressions. Similar fitting of the CVN transition temperature results revealed very low correlation coefficients, and those fits were not presented, but the CVN USE results were amenable to such regression analyses.

Hardness measurements for the four welds ranged from about 62 to $104 \mathrm{HRB}$. In all cases, the as-welded condition had the highest hardness for each weld. As expected, there were general trends of decreasing hardness with increasing values of the TP, but the results were more scattered at the higher temperatures, especially for the high-carbon welds. At the PWHT temperatures of $732^{\circ} \mathrm{C}\left(1350^{\circ} \mathrm{F}\right)$ and higher, the results showed generally consistent trends of decreasing hardness with increasing TP for each individual PWHT temperature, but the overall behavior showed too much scatter for inclusion in the trend line fitting.

As-welded strengths for the four welds ranged from 480 to $812 \mathrm{MPa}$ (70 to $118 \mathrm{ksi}$ ) for yield strength, and from 550 to $891 \mathrm{MPa}$ (80 to $129 \mathrm{ksi}$ ) for ultimate strength. After the PWHTs, the lowest yield and ultimate strengths measured were 226 and $406 \mathrm{MPa}$ (33 and $59 \mathrm{ksi})$, respectively. The yield strength results showed somewhat less scatter overall than did the hardness data, but the data at $732^{\circ} \mathrm{C}$ $\left(1350^{\circ} \mathrm{F}\right)$ and above still showed too much scatter, especially for the high-carbon welds, for inclusion in the fitting of the trend lines. In no case, as with the hardness results, did the heattreated yield strength exceed that of the aswelded condition. Except for weld 1, the ultimate strength results showed even more such scatter than did the hardness and yield strength results, with the high-carbon welds again showing significant differences at the higher temperatures. This was especially true for weld 3 , the high-carbon FCA weld, the only weld that exhibited higher ultimate strengths in some heat-treated conditions than in the aswelded condition. The average as-welded ultimate strength for weld 3 was $891 \mathrm{MPa}$ (129 ksi), while it reached $1125 \mathrm{MPa}$ (163 ksi) after the PWHT at $732^{\circ} \mathrm{C}\left(1350^{\circ} \mathrm{F}\right)$ for $5 \mathrm{~h}$. In fact, the ultimate strength results from all the $732^{\circ} \mathrm{C}$ PWHTs of weld 3 were higher than those in the as-welded condition.

Regarding the CVN results, the $27-\mathrm{J}(20 \mathrm{ft}-\mathrm{Ib})$ temperatures $\left(T_{27}\right)$ range from -81 to $-34^{\circ} \mathrm{C}$ $\left(-114\right.$ to $\left.-28^{\circ} \mathrm{F}\right)$, while the $T_{0}$ temperatures (midpoint of the transition region) range from about -62 to $-7^{\circ} \mathrm{C}\left(-79\right.$ to $\left.19^{\circ} \mathrm{F}\right)$. For the heattreated welds, the highest $\mathrm{T}_{0}$ temperature was $100^{\circ} \mathrm{C}\left(212^{\circ} \mathrm{F}\right)$ for the low-carbon FCA weld 4. The USE in the as-welded condition ranged from 36 to $206 \mathrm{~J}$ (26 to $152 \mathrm{ft}-\mathrm{lb}$ ). The very low USE was for weld 3 , the high-carbon FCA weld. The lowest USE for heat-treated welds was $27 \mathrm{~J}$ 


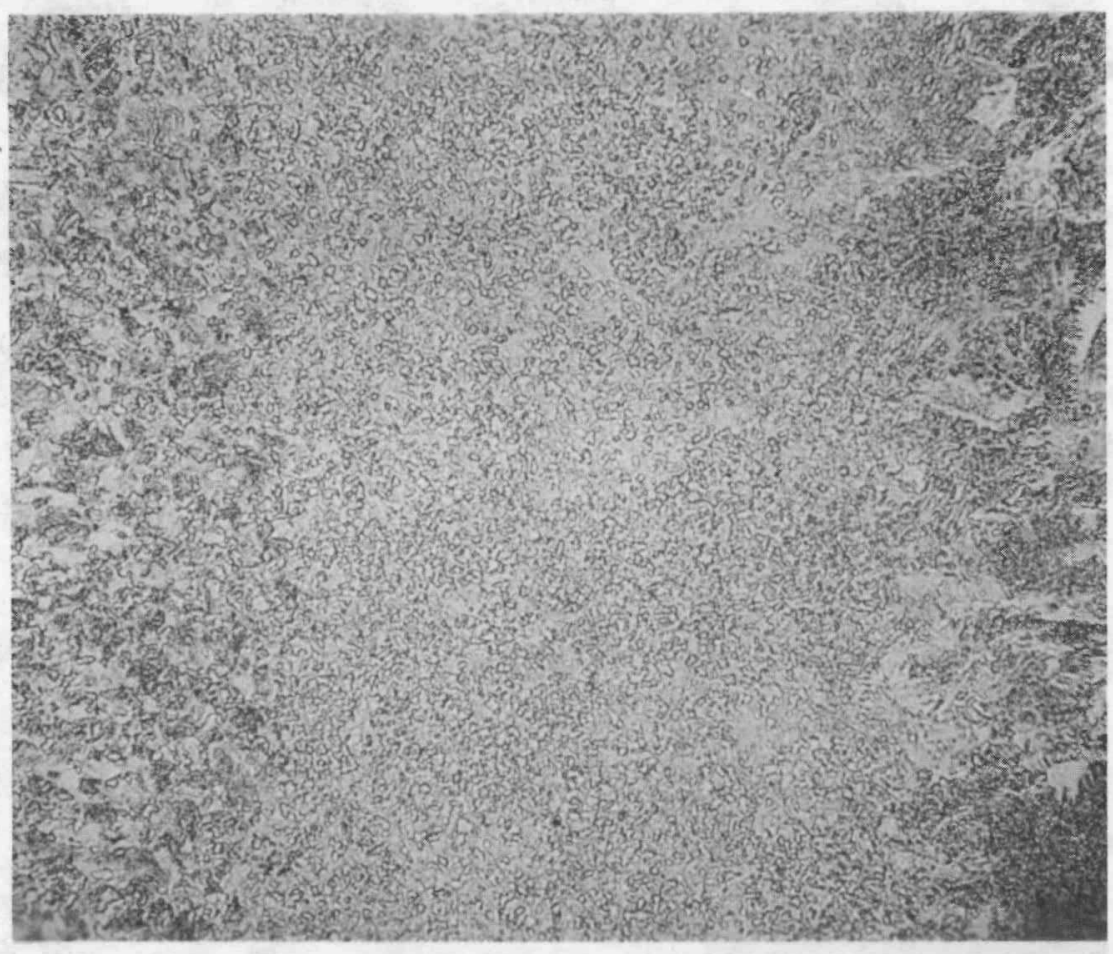

(a)

$400 \mu \mathrm{m}$

$50 x$

92-1404-1

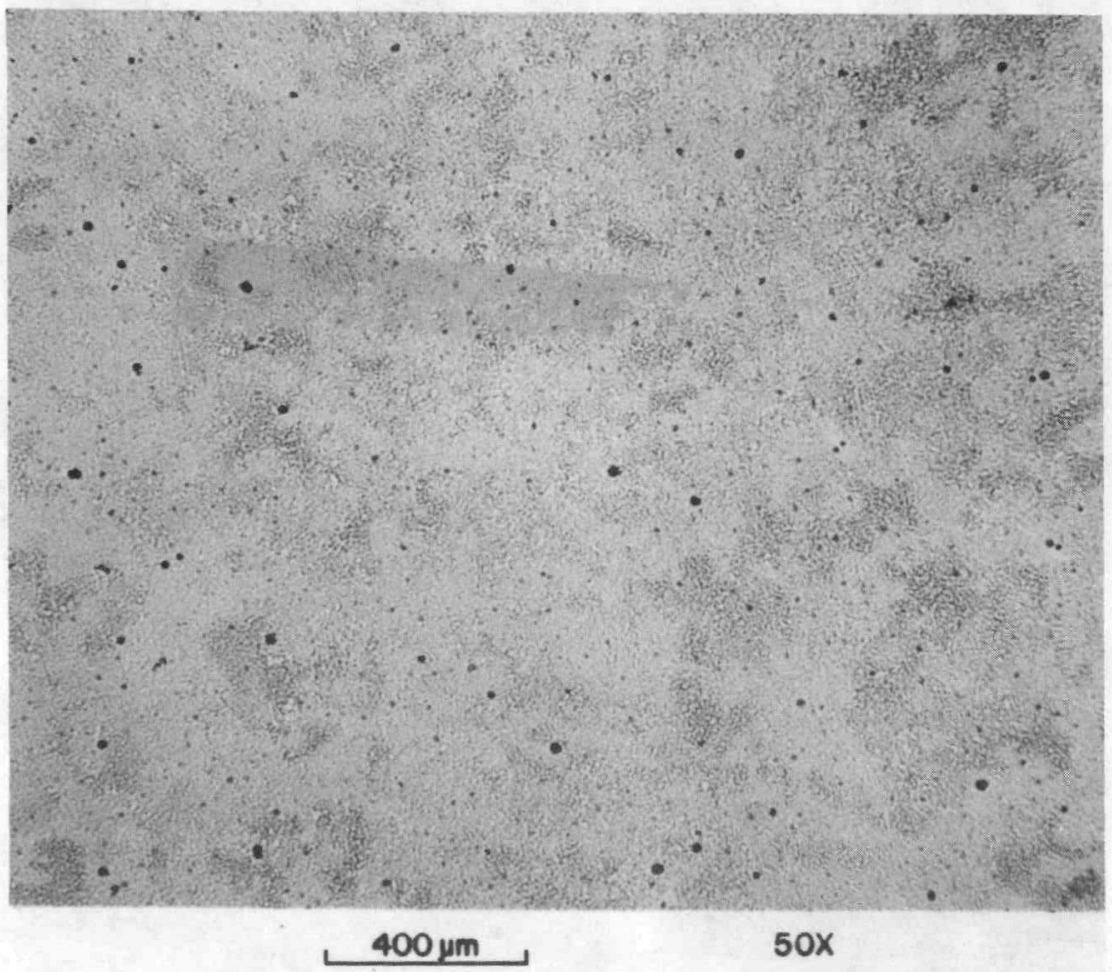

Figure 25. Micrographs of (a) welds 1 and (b) 3 , heat-treated at $1350^{\circ} \mathrm{F}$ for $5 \mathrm{~h}$. Transformation is essentially complete, and longer times do not seem to coarsen the transformed structure, as shown in (c) for weld 3 heat treated for $40 \mathrm{~h}$. 


\section{2-1404-2}

(c)

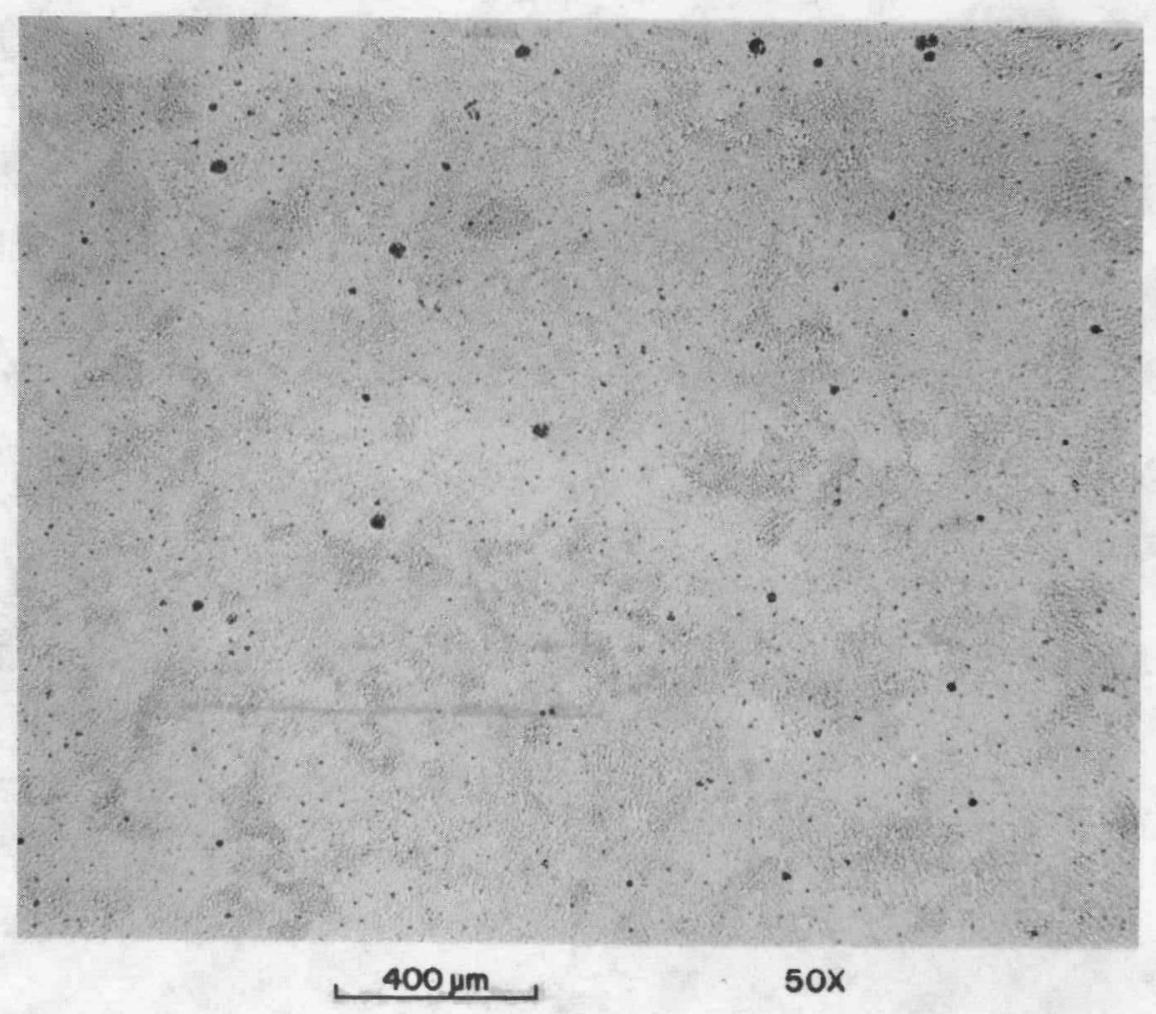

Figure 25. Continued. 


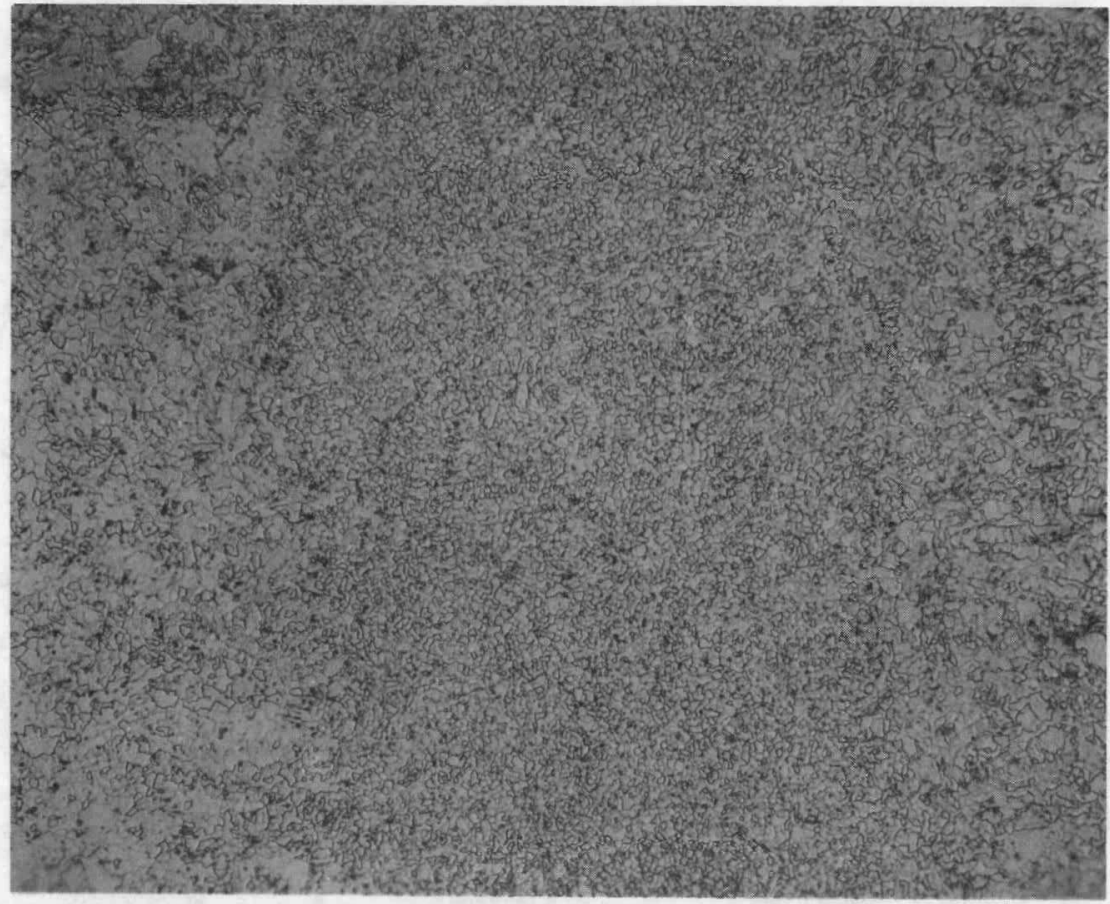

(a)

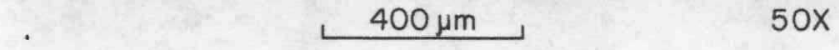

$92-1399-2$

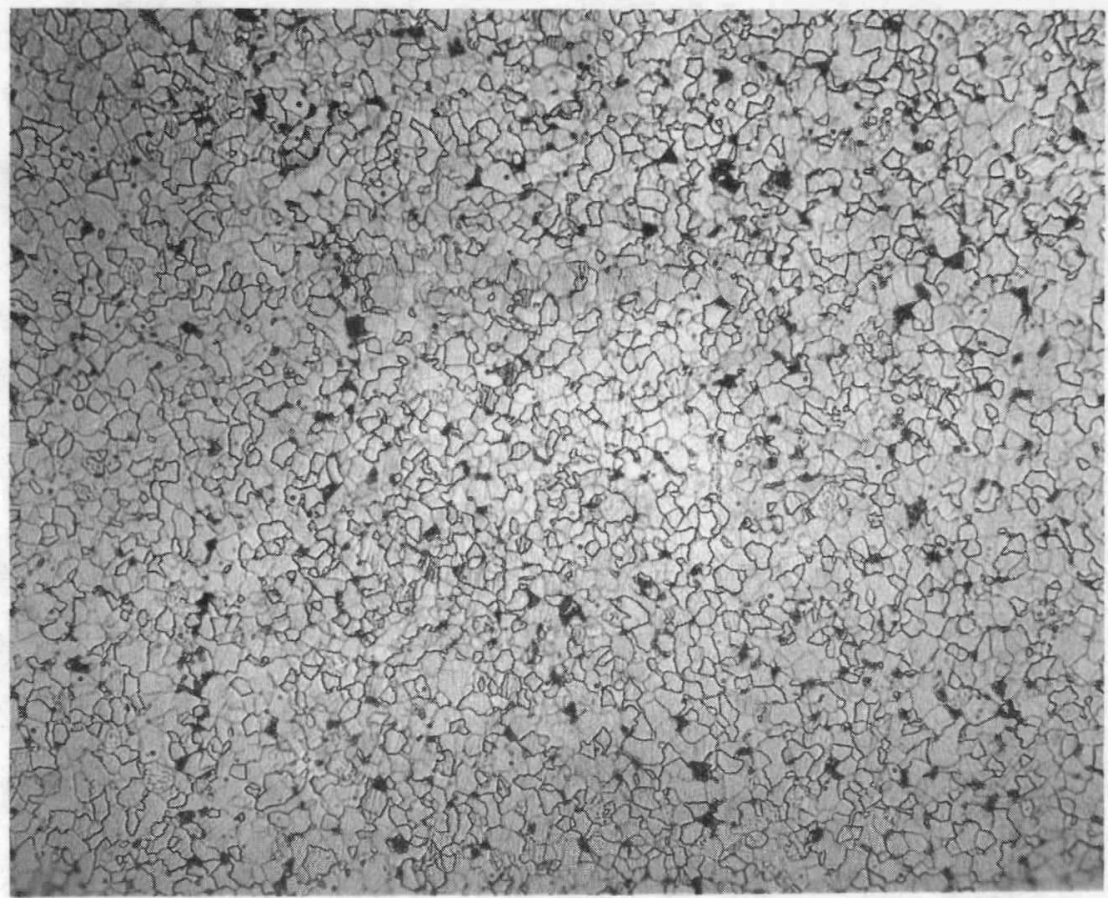

(b)

$$
400 \mu \mathrm{m}, 50 \mathrm{x}
$$

Figure 26. Micrographs of welds 1 through 4, heat treated at $1650^{\circ} \mathrm{F}$. Additional time at temperature for weld 1 at (a) $5 \mathrm{~h}$ and (b) $40 \mathrm{~h}$, results in coarsening of the structure. Welds 2,3 , and 4 at $1650^{\circ} \mathrm{F}$ for $40 \mathrm{~h}$ are shown in (c), (d), and (e), respectively. 


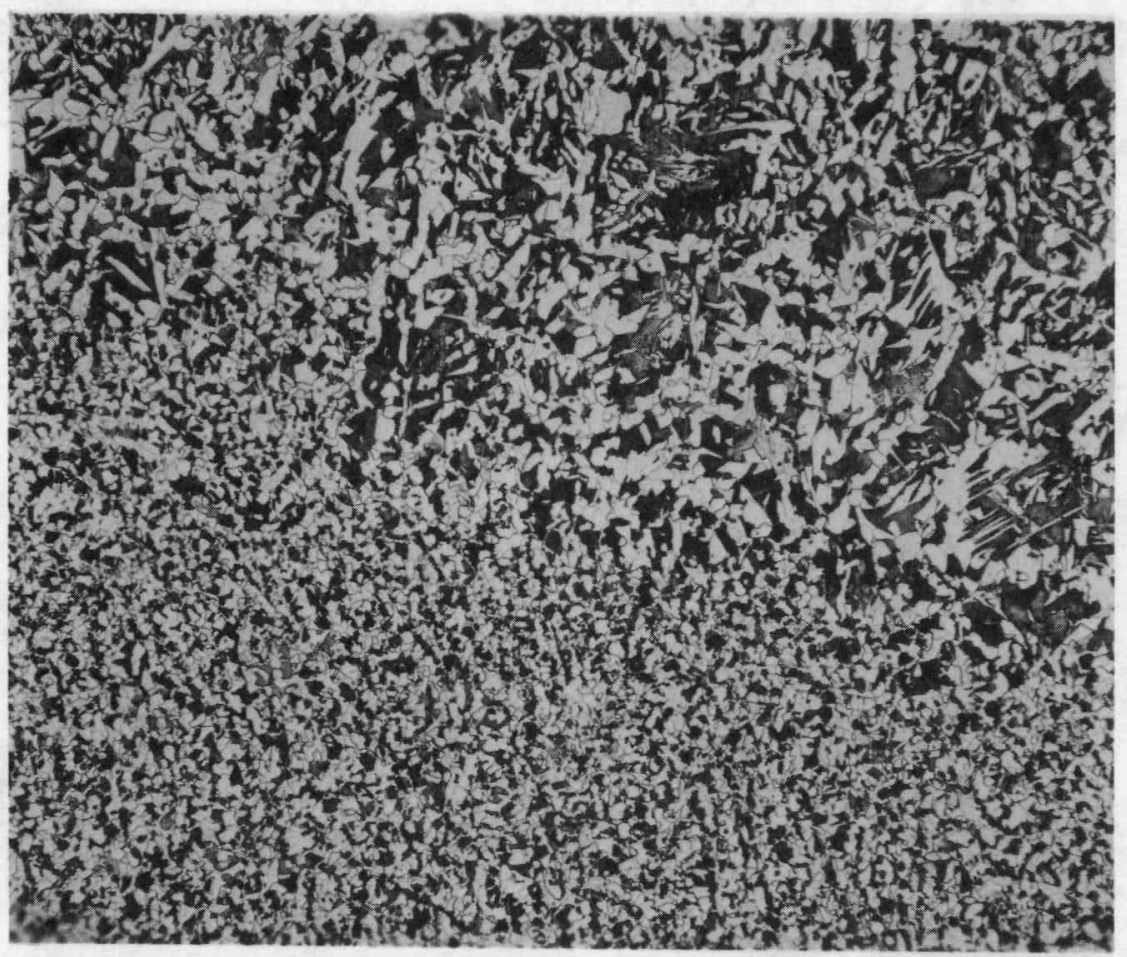

(c)

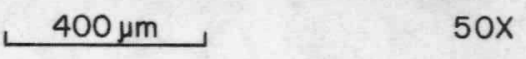

92-1462-1

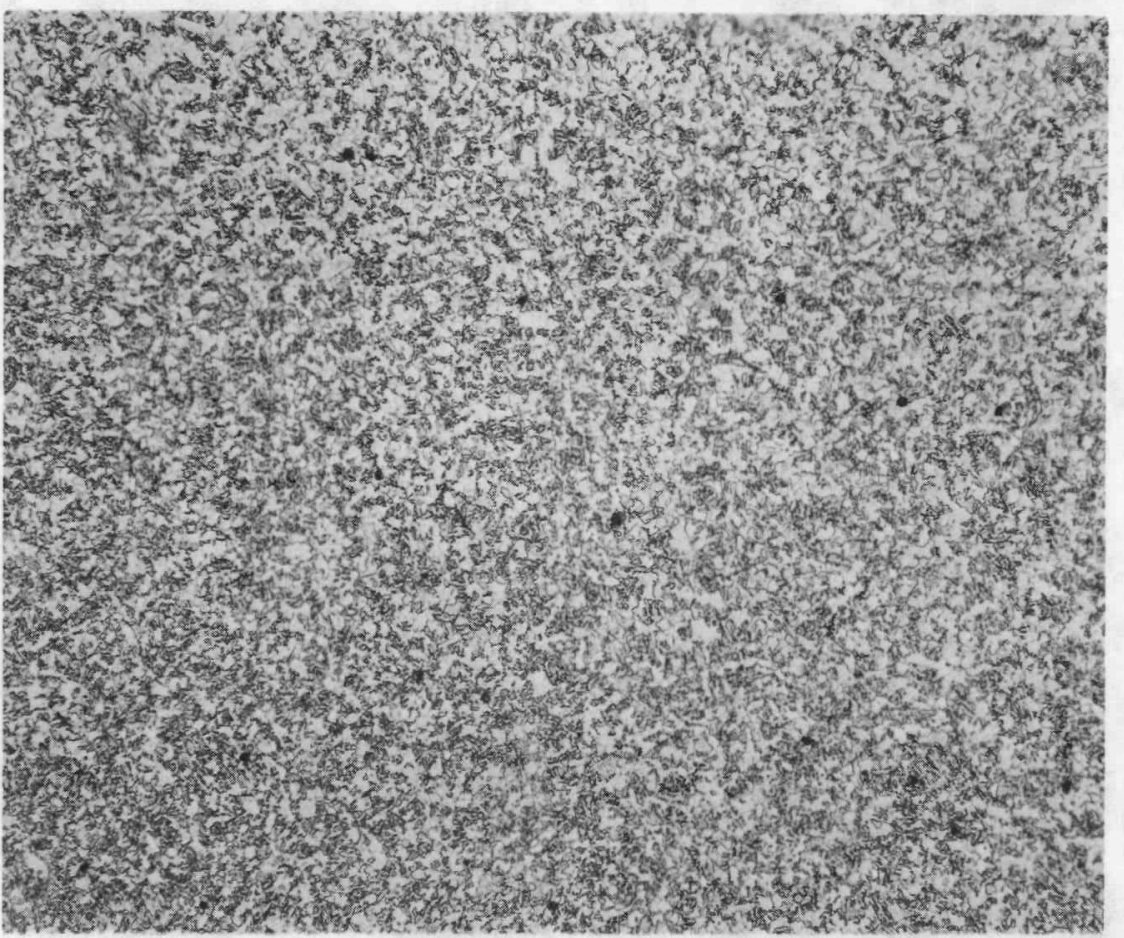

(d)

$400 \mu \mathrm{m}$

$50 x$

Figure 26. Continued. 
92-1408-5

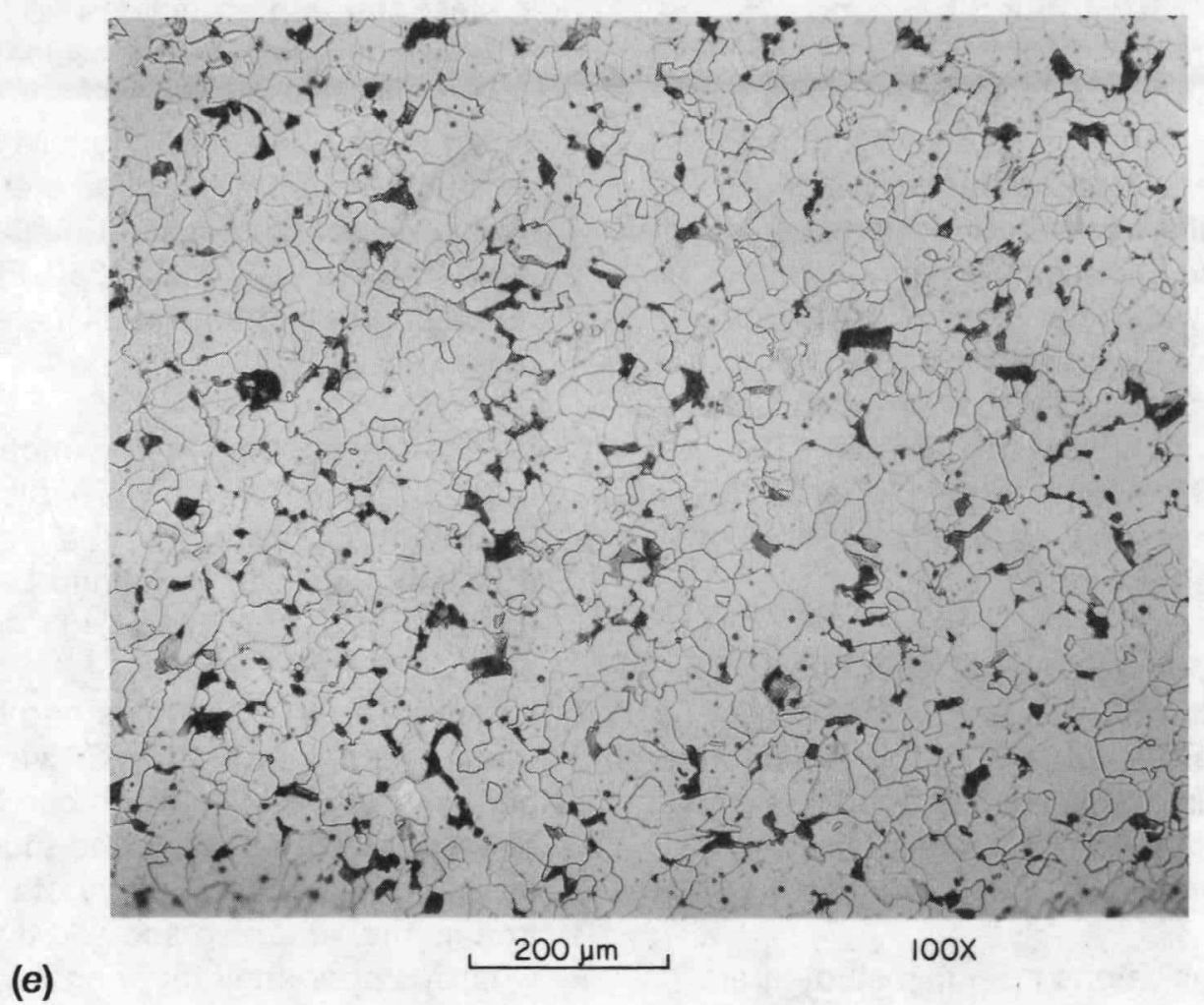

Figure 26. Continued. 
(20 $\mathrm{H}-\mathrm{lb})$ and was also shown by weld 3 after PWHT at $732^{\circ} \mathrm{C}\left(1350^{\circ} \mathrm{F}\right)$ for $5 \mathrm{~h}$. In most cases, the heat-treated $T_{0}$ and $\pi_{27}$ temperatures were higher than those in the aswelded condition. The results for $\pi_{68}$ in that regard were mixed. None of the transition temperature results were fitted for trends, however, because the scatter was too great. The USE results were relatively well behaved, however, and linear regressions at the two lowest PWHT temperatures showed consistent trends of increasing USE with increasing TP. The scatter in USE results for the higher PWHT temperatures, however, was also large, and consistent trends were not observed.

In general, the SMA welds had better overall toughness than the FCA welds. In particular, the high-carbon FCA weld (weld 4) had very poor toughness in the as-welded condition and achieved relatively good toughness only after certain PWHT conditions.

The principal conclusions from this study are:

1. For the hardness and tensile strength data, the results for heat treatments at 621 and $677^{\circ} \mathrm{C}\left(1150\right.$ and $\left.1250^{\circ} \mathrm{F}\right)$ were amenable to linear regression analysis using a time-temperature parameter, but for Charpy impact tests only the USE results were amenable to such analyses.

2. Heat treatments from 732 to $899^{\circ} \mathrm{C}(1350$ to $1650^{\circ} \mathrm{F}$ ) resulted in substantial changes in mechanical properties of these SMA and FCA welds, with the changes not amenable to prediction and highly dependent on the weld metal. Heat treatments in that temperature range should not be applied to these materials without prior qualification for the intended use.

3. For all four SMA and FCA welds, the heat-treated hardnesses and yield strengths were lower than in the as-welded condition.
4. Heat treatment at $899^{\circ} \mathrm{C}\left(1650^{\circ} \mathrm{F}\right)$ resulted in yield strength reductions up to about $50 \%$ from those in the as-welded condition.

5. Scatter in hardness and tensile strengths versus the tempering parameter was relatively high for all results at heat-treatment temperatures of $732^{\circ} \mathrm{C}\left(1350^{\circ} \mathrm{F}\right)$ and above, but was greatest for the ultimate strength data.

6. In most cases, the Charpy impact 27-J (20 ft-lb) temperatures were raised by heat treatment but, except for the high-carbon FCA weld (weld 3), remained below $10^{\circ} \mathrm{C}$ $\left(50^{\circ} \mathrm{F}\right)$.

7. In general, the SMA welds had better overall toughness than did the FCA welds. The high-carbon FCA weld exhibited substantial degradation in strength and toughness as a consequence of many of the heat treatments, and also showed a very low Charpy upper-shelf toughness.

\section{References}

1. W. H. Kearns, ed., Welding Handbook, 7th ed., Vol. 4, American Welding Society, Miami, 1982.

2. J. H. Hollomon and L. D. Jaffee, "TimeTemperature Relations in Tempering Steels," Trans. Am. Inst. Min. Metall. Eng. 162, 223-49 (1945).

3. F. R. Larson and J. Miller, "A TimeTemperature Relationship for Rupture and Creep Stress," Trans. ASME 74(5), 765-71 (September 1952). 
Appendix A

Hardness Data for Welds 1 Through 4 
Table A1. Hardness data for weld 1, low-carbon SMA

\begin{tabular}{|c|c|c|c|c|c|}
\hline SPEC & \multicolumn{2}{|c|}{ ANN TEMP } & ANN TWME & T.P. & BARDNESS \\
\hline ID & $\left({ }^{\circ} \mathrm{C}\right)$ & $\left.{ }^{\circ} \mathrm{F}\right)$ & $(\mathrm{HR})$ & $\left(\mathrm{x} 10^{-3}\right)$ & $($ HRB $)$ \\
\hline 100 & $\mathrm{AW}$ & $\mathrm{AW}$ & $\mathrm{AW}$ & 0 & 90.9 \\
\hline 111 & 621 & 1150 & 5 & 14.04 & 85.7 \\
\hline 112 & 621 & 1150 & 10 & 14.31 & 87.7 \\
\hline 113 & 621 & 1150 & 20 & 14.58 & 85.1 \\
\hline 114 & 621 & 1150 & 40 & 14.85 & 81.7 \\
\hline 121 & 677 & 1250 & 5 & 14.91 & 82.8 \\
\hline 122 & 677 & 1250 & 10 & 15.20 & 82.9 \\
\hline 123 & 677 & 1250 & 20 & 15.48 & 79.8 \\
\hline 124 & 677 & 1250 & 40 & 15.77 & 75.6 \\
\hline 131 & 732 & 1350 & 5 & 15.78 & 73.8 \\
\hline 132 & 732 & 1350 & 10 & 16.09 & 71.0 \\
\hline 133 & 732 & 1350 & 20 & 16.39 & 69.2 \\
\hline 134 & 732 & 1350 & 40 & 16.69 & 68.0 \\
\hline 141 & 788 & 1450 & 5 & 16.66 & 73.3 \\
\hline 142 & 788 & 1450 & 10 & 16.97 & 65.9 \\
\hline 143 & 788 & 1450 & 20 & 17.29 & 61.4 \\
\hline 144 & 788 & 1450 & 40 & 17.61 & 57.5 \\
\hline 151 & 843 & 1550 & 5 & 17.53 & 62.9 \\
\hline 152 & 843 & 1550 & 10 & 17.86 & 54.9 \\
\hline 153 & 843 & 1550 & 20 & 18.20 & 58.0 \\
\hline 154 & 843 & 1550 & 40 & 18.54 & 53.8 \\
\hline 161 & 899 & 1650 & 5 & 18.40 & 66.5 \\
\hline 162 & 899 & 1650 & 10 & 18.75 & 64.8 \\
\hline 163 & 899 & 1650 & 20 & 19.11 & 67.5 \\
\hline 164 & 899 & 1650 & 40 & 19.46 & 61.9 \\
\hline & & & & & \\
\hline
\end{tabular}

a AW - As-welded 
Table A2. Hardness data for weld 2, high-carbon SMA

\begin{tabular}{|c|c|c|c|c|c|}
\hline SPEC & \multicolumn{2}{|c|}{ ANN TEMP } & ANN TRME & T.P. & BARDNESS \\
\hline ID & $\left({ }^{\circ} \mathrm{C}\right)$ & $\left({ }^{\circ} \mathrm{F}\right)$ & $(\mathrm{HR})$ & $\left(\times 10^{-3}\right)$ & $($ HRB $)$ \\
\hline 200 & $\mathrm{AW}$ & AW & AW & 0 & 100.1 \\
\hline 211 & 621 & 1150 & 5 & 14.04 & 98.2 \\
\hline 212 & 621 & 1150 & 10 & 14.31 & 95.3 \\
\hline 213 & 621 & 1150 & 20 & 14.58 & 94.5 \\
\hline 214 & 621 & 1150 & 40 & 14.85 & 94.8 \\
\hline 221 & 677 & 1250 & 5 & 14.91 & 90.7 \\
\hline 222 & 677 & 1250 & 10 & 15.20 & 91.2 \\
\hline 223 & 677 & 1250 & 20 & 15.48 & 87.9 \\
\hline 224 & 677 & 1250 & 40 & 15.77 & 90.4 \\
\hline 231 & 732 & 1350 & 5 & 15.78 & 92.4 \\
\hline 232 & 732 & 1350 & 10 & 16.09 & 84.2 \\
\hline 233 & 732 & 1350 & 20 & 16.39 & 84.1 \\
\hline 234 & 732 & 1350 & 40 & 16.69 & 78.7 \\
\hline 241 & 788 & 1450 & 5 & 16.66 & 93.6 \\
\hline 242 & 788 & 1450 & 10 & 16.97 & 86.5 \\
\hline 243 & 788 & 1450 & 20 & 17.29 & 81.5 \\
\hline 244 & 788 & 1450 & 40 & 17.61 & 77.8 \\
\hline 251 & 843 & 1550 & 5 & 17.53 & 89.5 \\
\hline 252 & 843 & 1550 & 10 & 17.86 & 82.2 \\
\hline 253 & 843 & 1550 & 20 & 18.20 & 83.0 \\
\hline 254 & 843 & 1550 & 40 & 18.54 & 77.9 \\
\hline 261 & 899 & 1650 & 5 & 18.40 & 88.2 \\
\hline 262 & 899 & 1650 & 10 & 18.75 & 81.6 \\
\hline 263 & 899 & 1650 & 20 & 19.11 & 80.8 \\
\hline 264 & 899 & 1650 & 40 & 19.46 & 81.7 \\
\hline & & & & & \\
\hline
\end{tabular}

a AW-As-welded 
Table A3. Hardness data for weld 3, high-carbon FCA

\begin{tabular}{|c|c|c|c|c|c|}
\hline SPEC & \multicolumn{2}{|c|}{ ANN TEMPQ } & ANN TIME & T.P. & HARDNESS \\
\hline ID & $\left({ }^{\circ} \mathrm{C}\right)$ & I $\left.^{\circ}\right)$ & $(\mathrm{HR})$ & $\left(\times 10^{-3}\right)$ & (HRB) \\
\hline 300 & $\mathrm{AW}$ & $\mathrm{AW}$ & $\mathrm{AW}$ & 0 & 104.0 \\
\hline 311 & 621 & 1150 & 5 & 14.04 & 101.6 \\
\hline 312 & 621 & 1150 & 10 & 14.31 & 99.7 \\
\hline 313 & 621 & 1150 & 20 & 14.58 & 102.7 \\
\hline 314 & 621 & 1150 & 40 & 14.85 & 101.6 \\
\hline 321 & 677 & 1250 & 5 & 14.91 & 99.1 \\
\hline 322 & 677 & 1250 & 10 & 15.20 & 98.4 \\
\hline 323 & 677 & 1250 & 20 & 15.48 & 90.5 \\
\hline 324 & 677 & 1250 & 40 & 15.77 & 80.1 \\
\hline 331 & 732 & 1350 & 5 & 15.78 & 99.7 \\
\hline 332 & 732 & 1350 & 10 & 16.09 & 92.6 \\
\hline 333 & 732 & 1350 & 20 & 16.39 & 90.4 \\
\hline 334 & 732 & 1350 & 40 & 16.69 & 83.3 \\
\hline 341 & 788 & 1450 & 5 & 16.66 & 96.8 \\
\hline 342 & 788 & 1450 & 10 & 16.97 & 93.9 \\
\hline 343 & 788 & 1450 & 20 & 17.29 & 90.5 \\
\hline 344 & 788 & 1450 & 40 & 17.61 & 85.2 \\
\hline 351 & 843 & 1550 & 5 & 17.53 & 94.7 \\
\hline 352 & 843 & 1550 & 10 & 17.86 & 89.9 \\
\hline 353 & 843 & 1550 & 20 & 18.20 & 86.3 \\
\hline 354 & 843 & 1550 & 40 & 18.54 & 84.4 \\
\hline 361 & 899 & 1650 & 5 & 18.40 & 90.7 \\
\hline 362 & 899 & 1650 & 10 & 18.75 & 86.2 \\
\hline 363 & 899 & 1650 & 20 & 19.11 & 84.3 \\
\hline 364 & 899 & 1650 & 40 & 19.46 & 82.4 \\
\hline & & & & & \\
\hline
\end{tabular}

a AW - As-welded 
Table A4. Hardness data for weld 4, low-carbon FCA

\begin{tabular}{|c|c|c|c|c|c|}
\hline SPEC & \multicolumn{2}{|c|}{ ANN TEMP } & ANN TDME & T.P. & BARDNESS \\
\hline ID & $\left({ }^{\circ} \mathrm{C}\right)$ & $\left({ }^{\circ} \mathrm{F}\right)$ & (HR & $\left(\times 10^{-3}\right)$ & (HRB) \\
\hline 400 & AW & AW & AW & 0 & 97.8 \\
\hline 411 & 621 & 1150 & 5 & 14.04 & 96.0 \\
\hline 412 & 621 & 1150 & 10 & 14.31 & 93.5 \\
\hline 413 & 621 & 1150 & 20 & 14.58 & 92.8 \\
\hline 414 & 621 & 1150 & 40 & 14.85 & 93.3 \\
\hline 421 & 677 & 1250 & 5 & 14.91 & 91.1 \\
\hline 422 & 677 & 1250 & 10 & 15.20 & 85.1 \\
\hline 423 & 677 & 1250 & 20 & 15.48 & 80.2 \\
\hline 424 & 677 & 1250 & 40 & 15.77 & 78.9 \\
\hline 431 & 732 & 1350 & 5 & 15.78 & 83.4 \\
\hline 432 & 732 & 1350 & 10 & 16.09 & 82.3 \\
\hline 433 & 732 & 1350 & 20 & 16.39 & 80.1 \\
\hline 434 & 732 & 1350 & 40 & 16.69 & 79.7 \\
\hline 441 & 788 & 1450 & 5 & 16.66 & 81.5 \\
\hline 442 & 788 & 1450 & 10 & 16.97 & 77.7 \\
\hline 443 & 788 & 1450 & 20 & 17.29 & 76.5 \\
\hline 444 & 788 & 1450 & 40 & 17.61 & 70.4 \\
\hline 451 & 843 & 1550 & 5 & 17.53 & 77.7 \\
\hline 452 & 843 & 1550 & 10 & 17.86 & 76.1 \\
\hline 453 & 843 & 1550 & 20 & 18.20 & 77.3 \\
\hline 454 & 843 & 1550 & 40 & 18.54 & 70.8 \\
\hline 461 & 899 & 1650 & 5 & 18.40 & 77.3 \\
\hline 462 & 899 & 1650 & 10 & 18.75 & 79.0 \\
\hline 463 & 899 & 1650 & 20 & 19.11 & 77.2 \\
\hline 464 & 899 & 1650 & 40 & 19.46 & 74.7 \\
\hline & & & & & \\
\hline
\end{tabular}

a AW - As-welded 
Appendix B

Tensile Data for Welds 1 Through 4 
Table B1. Tensile data for weld 1, low-carbon SMA

\begin{tabular}{|c|c|c|c|c|c|c|c|c|c|c|}
\hline SPEC & \multicolumn{2}{|c|}{ AnN Tenuppa } & \multirow{2}{*}{$\frac{\text { ANN TDME }}{\text { (HR) }}$} & \multirow{2}{*}{$\frac{\text { T.P. }}{\left(x 10^{-3}\right)}$} & \multicolumn{2}{|c|}{ YIELD STRUNGTH } & \multicolumn{2}{|c|}{ ULTWMATE STRENGTH } & \multirow{2}{*}{\begin{tabular}{|c|} 
UNIFORM EL \\
$(\%)$
\end{tabular}} & \multirow{2}{*}{$\begin{array}{c}\text { TOTALEI } \\
\text { (\%) }\end{array}$} \\
\hline ID & (०OC) & $\left({ }^{\circ} \mathrm{F}\right)$ & & & (ksi) & (MPa) & $(\mathrm{ks} 1)$ & (MPa) & & \\
\hline $100 \mathrm{Al}$ & $\overline{\mathrm{AW}}$ & $\mathbf{A W}$ & $\mathrm{AW}$ & 0 & 67.7 & 467 & 79.2 & 546 & 7.7 & 16.5 \\
\hline $100 \mathrm{B1}$ & $\overline{\mathrm{AW}}$ & $\overline{\mathrm{AW}}$ & $\overline{\mathrm{AW}}$ & 0 & 71.7 & $4 \overline{494}$ & 80.2 & 553 & $\overline{3.3}$ & 8.1 \\
\hline IIIAI & 621 & 1150 & 5 & 14.04 & 65.3 & 450 & 76.4 & 526 & 8.6 & 16.7 \\
\hline $111 \mathrm{BI}$ & 621 & 1150 & 5 & 14.04 & 68.3 & 471 & 80.0 & 551 & 10.0 & 17.9 \\
\hline $112 \mathrm{AI}$ & 621 & 1150 & 10 & 14.31 & 63.3 & 436 & 75.8 & 523 & 8.6 & 17.5 \\
\hline 11281 & 621 & 1150 & 10 & 14.31 & 65.1 & 449 & 76.8 & 530 & 7.2 & 15.2 \\
\hline 113A1 & 621 & 1150 & 20 & 14.58 & 61.7 & 425 & 73.9 & 509 & 8.9 & 18.2 \\
\hline $113 \mathrm{BI}$ & 621 & 1150 & 20 & 14.58 & 64.0 & 441 & 75.7 & 522 & 9.5 & 19.2 \\
\hline $114 \mathrm{Al}$ & 621 & 1150 & 40 & 14.85 & 61.3 & 422 & 72.9 & 502 & 7.9 & 19.0 \\
\hline $114 \mathrm{BI}$ & 621 & 1150 & 40 & 14.85 & 61.7 & 425 & 75.1 & 518 & 10.4 & 20.8 \\
\hline 12IA1 & 677 & 1250 & 5 & 14.91 & 60.9 & 420 & 73.5 & 507 & 9.0 & 18.4 \\
\hline 12181 & 677 & 1250 & 5 & 14.91 & 59.7 & 412 & 66.6 & 459 & 3.4 & 8.4 \\
\hline $122 \mathrm{Al}$ & 677 & 1250 & 10 & 15.20 & 58.7 & 405 & 71.5 & 493 & 9.8 & 18.5 \\
\hline $122 \mathrm{BI}$ & 677 & 1250 & 10 & 15.20 & 60.4 & 417 & 72.5 & 500 & 10.1 & $\overline{21.6}$ \\
\hline $123 \mathrm{~A} 1$ & 677 & 1250 & 20 & 15.48 & 56.4 & 389 & 69.8 & 481 & 10.6 & 19.7 \\
\hline $123 \mathrm{BI}$ & 677 & 1250 & 20 & 15.48 & 56.4 & 389 & 68.2 & 470 & 6.8 & 13.1 \\
\hline $124 \mathrm{AI}$ & 677 & 1250 & 40 & 15.77 & 53.1 & 366 & 67.8 & 467 & 9.5 & 19.9 \\
\hline $124 \mathrm{Bl}$ & 677 & 1250 & 40 & 15.77 & 50.3 & 347 & 58.5 & 403 & 3.9 & 6.7 \\
\hline 131A1 & 732 & 1350 & 5 & 15.78 & 49.2 & 339 & 69.0 & 476 & 13.2 & 22.7 \\
\hline $132 \mathrm{AI}$ & 732 & 1350 & 10 & 16.09 & 48.9 & 337 & 69.0 & 476 & $\overline{12.2}$ & 21.0 \\
\hline $132 \mathrm{B1}$ & 732 & 1350 & 10 & 16.09 & 47.8 & 329 & 67.9 & 468 & 13.2 & 22.8 \\
\hline 133A1 & 732 & 1350 & 20 & $16 . \overline{39}$ & 46.2 & 318 & 69.6 & 480 & 13.9 & 23.6 \\
\hline $134 \mathrm{Al}$ & 732 & 1350 & 40 & 16.69 & 43.9 & 302 & 67.0 & 462 & 14.9 & 24.5 \\
\hline $134 \mathrm{Bl}$ & 732 & 1350 & 40 & 16.69 & 39.1 & 270 & 62.1 & 428 & 13.2 & 23.0 \\
\hline 141AI & 788 & 1450 & 5 & 16.66 & 47.1 & 325 & 69.3 & 478 & 13.5 & 22.6 \\
\hline 14181 & 788 & 1450 & 5 & 16.66 & 48.5 & 335 & 63.9 & 441 & 15.3 & 25.8 \\
\hline 142A1 & 788 & 1450 & 10 & 16.97 & 40.7 & 281 & 69.0 & 476 & 15.5 & 24.8 \\
\hline
\end{tabular}


Table B1. Continued

\begin{tabular}{|l|l|l|l|l|l|l|l|l|l|l|}
\hline $142 \mathrm{~B} 1$ & 788 & 1450 & 10 & 16.97 & 43.9 & 303 & 68.2 & 470 & 17.1 & 29.3 \\
\hline $143 \mathrm{~A} 1$ & 788 & 1450 & 20 & 17.29 & 41.7 & 287 & 67.6 & 466 & 14.5 & 25.0 \\
\hline $143 \mathrm{~B} 1$ & 788 & 1450 & 20 & 17.29 & 45.1 & 311 & 65.3 & 450 & 13.2 & 22.6 \\
\hline $144 \mathrm{~A} 1$ & 788 & 1450 & 40 & 17.61 & 41.0 & 282 & 64.8 & 446 & 16.1 & 27.4 \\
\hline $144 \mathrm{~B} 1$ & 788 & 1450 & 40 & 17.61 & 43.2 & 298 & 64.6 & 446 & 16.5 & 26.9 \\
\hline $151 \mathrm{~A} 1$ & 843 & 1550 & 5 & 17.53 & 42.4 & 293 & 64.1 & 442 & 17.6 & 28.5 \\
\hline $152 \mathrm{~A} 1$ & 843 & 1550 & 10 & 17.86 & 39.0 & 269 & 63.8 & 440 & 19.0 & 29.7 \\
\hline $153 \mathrm{~B} 1$ & 843 & 1550 & 20 & 18.20 & 41.5 & 286 & 63.1 & 435 & 15.2 & 25.9 \\
\hline $154 \mathrm{~A} 1$ & 843 & 1550 & 40 & 18.54 & 39.6 & 273 & 63.4 & 437 & 19.3 & 30.9 \\
\hline $154 \mathrm{~B} 1$ & 843 & 1550 & 40 & 18.54 & 41.8 & 288 & 63.1 & 435 & 17.0 & 27.1 \\
\hline $161 \mathrm{~A} 1$ & 899 & 1650 & 5 & 18.40 & 38.2 & 264 & 61.4 & 424 & 19.7 & 33.1 \\
\hline $161 \mathrm{~B} 1$ & 899 & 1650 & 5 & 18.40 & 38.2 & 264 & 61.0 & 421 & 15.8 & 26.0 \\
\hline $162 \mathrm{~A} 1$ & 899 & 1650 & 10 & 18.75 & 35.6 & 246 & 59.7 & 412 & 17.7 & 28.3 \\
\hline $163 \mathrm{~A} 1$ & 899 & 1650 & 20 & 19.11 & 32.8 & 226 & 58.9 & 406 & 17.2 & 28.3 \\
\hline $163 \mathrm{~B} 1$ & 899 & 1650 & 20 & 19.11 & 38.5 & 266 & 59.6 & 411 & 16.0 & 26.0 \\
\hline $164 \mathrm{~A} 1$ & 899 & 1650 & 40 & 19.46 & 35.4 & 244 & 58.9 & 406 & 17.3 & 29.0 \\
\hline $164 \mathrm{~B} 1$ & 899 & 1650 & 40 & 19.46 & 35.5 & 245 & 59.0 & 407 & 18.9 & 27.4 \\
\hline
\end{tabular}

a AW-As-welded 
Table B2. Tensile data for weld 2, high-carbon SMA

\begin{tabular}{|c|c|c|c|c|c|c|c|c|c|c|}
\hline SPEC & \multicolumn{2}{|c|}{ ANW TEMPa } & \multirow{2}{*}{$\begin{array}{c}\text { ANN TRMEQ } \\
\text { (HR) }\end{array}$} & \multirow{2}{*}{$\begin{array}{c}\text { T.P. } \\
\left(\times 10^{-3}\right)\end{array}$} & \multicolumn{2}{|c|}{ YIETD STRENGTH } & \multicolumn{2}{|c|}{ ULTMATE STRENGTH } & \multirow{2}{*}{\begin{tabular}{|c|} 
UNWORM EI \\
$(\%)$
\end{tabular}} & \multirow{2}{*}{$\begin{array}{c}\text { TOTAL EI } \\
\text { (\%) }\end{array}$} \\
\hline ID & $\left.{ }^{\circ} \mathrm{C}\right)$ & ('F) & & & (ksi) & (MPa) & (ksI) & $(\mathrm{MPa})$ & & \\
\hline 200A1 & $\overline{\mathrm{AW}}$ & $\overline{\mathrm{AW}}$ & $\mathrm{AW}$ & 0 & 91.2 & 629 & 113.9 & 785 & 7.8 & 14.7 \\
\hline $200 B 1$ & $\overline{\mathrm{AW}}$ & $\overline{\mathrm{AW}}$ & $\overline{\mathrm{AW}}$ & $\overline{0}$ & 103.8 & 716 & 122.7 & 846 & 6.7 & 11.2 \\
\hline 211A1 & 621 & 1150 & 5 & 14.04 & 77.7 & 536 & 100.2 & 691 & 7.9 & 15.5 \\
\hline $211 B 1$ & $\overline{621}$ & 1150 & 5 & 14.04 & 87.6 & 604 & 107.9 & 744 & 8.3 & 13.1 \\
\hline 212AI & 621 & 1150 & 10 & 14.31 & 80.4 & 554 & 100.4 & 692 & 6.8 & 9.0 \\
\hline $212 B 1$ & 621 & 1150 & 10 & 14.31 & 86.0 & 593 & 106.0 & 731 & 9.9 & 18.6 \\
\hline 213A1 & 621 & 1150 & 20 & 14.58 & 79.2 & 546 & 100.7 & 694 & 8.2 & 13.5 \\
\hline $213 \overline{B 1}$ & 621 & 1150 & 20 & 14.58 & 82.8 & 571 & 98.3 & 678 & 4.9 & 8.2 \\
\hline 214A1 & 621 & 1150 & 40 & 14.85 & 77.0 & 531 & 96.7 & 667 & 9.7 & 15.0 \\
\hline $214 \mathrm{BI}$ & 621 & 1150 & 40 & 14.85 & 81.6 & 563 & 102.7 & 708 & 9.6 & 16.3 \\
\hline $221 A 1$ & 677 & 1250 & 5 & 14.91 & 73.7 & 508 & 96.0 & 662 & 9.5 & 16.8 \\
\hline $221 B 1$ & 677 & 1250 & 5 & 14.91 & 78.4 & 540 & 98.5 & 679 & 9.3 & 16.5 \\
\hline $222 \mathrm{Al}$ & 677 & 1250 & 10 & 15.20 & 69.7 & 481 & 84.0 & 579 & 4.2 & 7.6 \\
\hline $222 B 1$ & 677 & 1250 & 10 & 15.20 & 78.4 & 540 & 98.5 & 679 & 9.3 & 16.5 \\
\hline $223 \mathrm{Al}$ & 677 & 1250 & 20 & 15.48 & 73.3 & 506 & 91.8 & 633 & 10.2 & 18.0 \\
\hline $223 \mathrm{BI}$ & $\overline{677}$ & 1250 & 20 & 15.48 & 73.9 & 510 & 92.7 & 639 & 8.7 & 15.1 \\
\hline $224 \mathrm{AI}$ & 677 & 1250 & 40 & 15.77 & 66.9 & 461 & 83.7 & 577 & 6.4 & 10.2 \\
\hline $224 \mathrm{BI}$ & 677 & 1250 & 40 & 15.77 & 69.7 & 481 & 89.4 & 616 & 9.6 & 14.3 \\
\hline $231 \mathrm{Al}$ & 732 & 1350 & 5 & 15.78 & 76.1 & 525 & 101.4 & 699 & 12.2 & 19.4 \\
\hline 231B1 & 732 & 1350 & 5 & 15.78 & 81.6 & 563 & 105.3 & 726 & 12.6 & 19.7 \\
\hline $232 \mathrm{Al}$ & 732 & 1350 & 10 & 16.09 & 73.7 & 508 & 99.6 & 687 & 12.7 & 19.3 \\
\hline 232B1 & 732 & 1350 & 10 & 16.09 & 72.5 & 500 & 88.5 & 610 & 4.1 & 5.9 \\
\hline $233 \mathrm{Al}$ & 732 & 1350 & 20 & 16.39 & 71.1 & 490 & 96.5 & 666 & 8.2 & 12.3 \\
\hline $233 \mathrm{B1}$ & 732 & 1350 & 20 & 16.39 & 79.9 & 551 & 101.0 & 696 & 7.1 & 8.3 \\
\hline 234A1 & 732 & 1350 & 40 & 16.69 & 75.2 & 518 & 103.7 & 715 & 10.1 & 17.0 \\
\hline 234B1 & 732 & 1350 & 40 & 16.69 & 82.7 & 570 & 105.6 & 728 & 11.2 & 19.5 \\
\hline 241A1 & 788 & 1450 & 5 & 16.66 & 71.9 & 496 & 99.3 & 684 & 11.5 & 15.4 \\
\hline
\end{tabular}


Table B2. Continued

\begin{tabular}{|c|c|c|c|c|c|c|c|c|c|c|}
\hline $241 B 1$ & 788 & 1450 & 5 & 16.66 & 72.0 & 496 & 95.1 & 656 & 6.6 & 9.0 \\
\hline $242 A 1$ & 788 & 1450 & 10 & 16.97 & 73.5 & 507 & 100.8 & 695 & 14.2 & 21.9 \\
\hline 242B1 & 788 & 1450 & 10 & 16.97 & 72.0 & 497 & 100.3 & 692 & 12.9 & 17.9 \\
\hline$\overline{243 A 1}$ & 788 & 1450 & 20 & 17.29 & 64.0 & 441 & 87.4 & 603 & 6.3 & 8.4 \\
\hline $244 A 1$ & 788 & 1450 & 40 & 17.61 & 67.6 & 466 & 97.2 & 670 & 13.3 & 20.5 \\
\hline $251 \mathrm{Al}$ & 843 & 1550 & 5 & 17.53 & 59.2 & 408 & $\overline{93.2}$ & $\overline{643}$ & 13.9 & 17.0 \\
\hline $251 B 1$ & 843 & 1550 & 5 & 17.53 & 57.5 & 397 & 93.5 & 644 & $\overline{13.1}$ & 20.8 \\
\hline $252 \mathrm{Al}$ & $\overline{843}$ & 1550 & 10 & 17.86 & 60.6 & 418 & $\overline{91.4}$ & 630 & 12.1 & 16.1 \\
\hline $252 \mathrm{B1}$ & $\overline{843}$ & 1550 & 10 & 17.86 & 63.3 & 437 & 92.1 & 635 & 12.9 & 15.2 \\
\hline 253Al & 843 & 1550 & 20 & 18.20 & 57.1 & 394 & 92.4 & 637 & 12.6 & 18.9 \\
\hline $253 \mathrm{Bl}$ & $\overline{843}$ & 1550 & 20 & 18.20 & 57.3 & 395 & 92.8 & 640 & 13.8 & 21.1 \\
\hline $254 A 1$ & 843 & 1550 & 40 & 18.54 & 54.7 & 377 & 89.2 & 615 & 12.3 & 18.6 \\
\hline $254 \mathrm{BI}$ & 843 & 1550 & 20 & 18.20 & 56.9 & 392 & 92.2 & 636 & 12.8 & 17.8 \\
\hline$\overline{261 A 1}$ & 899 & 1650 & 5 & 18.40 & 57.1 & 393 & 90.9 & 627 & 12.1 & 15.5 \\
\hline 26181 & 899 & 1650 & 5 & 18.40 & 55.4 & 382 & 90.7 & 626 & 13.1 & 20.4 \\
\hline $262 \mathrm{Al}$ & 899 & 1650 & 10 & 18.75 & 57.9 & 399 & 89.1 & 615 & 12.1 & 15.1 \\
\hline 262B1 & 899 & 1650 & 10 & 18.75 & 60.7 & 419 & 90.3 & 622 & 13.4 & 20.9 \\
\hline $263 \mathrm{Al}$ & 899 & 1650 & 20 & 19.11 & 52.3 & 360 & 90.5 & 624 & 12.8 & 20.8 \\
\hline $263 B 1$ & 899 & 1650 & 20 & 19.11 & 52.7 & 363 & 90.5 & 624 & 12.0 & 18.0 \\
\hline $264 A 1$ & 899 & 1650 & 40 & 19.46 & 51.6 & 356 & 89.5 & 617 & 13.0 & 18.9 \\
\hline 26481 & 899 & 1650 & 40 & 19.46 & 50.6 & 349 & 88.8 & 612 & 10.9 & 13.6 \\
\hline
\end{tabular}

a AW - As-weldod 
Table B3. Tensile data for weld 3, high-carbon FCA

\begin{tabular}{|c|c|c|c|c|c|c|c|c|c|c|}
\hline BPEC & \multicolumn{2}{|c|}{ ANI TEMP ${ }^{a}$} & \multirow{2}{*}{$\frac{\text { ANN TDME }}{(\text { HR) }}$} & \multirow{2}{*}{$\frac{\text { T.P. }}{\left(x 10^{-3}\right)}$} & \multicolumn{2}{|c|}{ YLWD STRENGTH } & \multicolumn{2}{|c|}{ ULTUAATE STRENGTH } & \multirow{2}{*}{$\begin{array}{c}\text { UNF ELONG } \\
\text { (\%) }\end{array}$} & \multirow{2}{*}{$\begin{array}{c}\text { TOT ELONG } \\
\text { (\%) }\end{array}$} \\
\hline ID & $\left.{ }^{\circ} \mathrm{C}\right)$ & $T^{\circ} \mathrm{F}$ & & & (ksi) & (MPa) & (ksi) & (MPa) & & \\
\hline 300A1 & $\overline{\mathrm{AW}}$ & $\overline{\mathbf{A W}}$ & AW & 0 & 126.0 & 869 & 137.3 & 947 & 4.2 & 10.6 \\
\hline $300 \mathrm{B5}$ & $\overline{A W}$ & $\overline{A W}$ & $\overline{\mathrm{AW}}$ & 0 & 109.5 & 755 & 121.2 & 836 & 4.2 & 11.1 \\
\hline 311AI & 621 & 1150 & 5 & 14.04 & 108.6 & 749 & 122.0 & 841 & 6.2 & 12.2 \\
\hline $312 \mathrm{Cl}$ & 621 & 1150 & 10 & 14.31 & 110.5 & 762 & 122.0 & 841 & 8.2 & 13.5 \\
\hline $312 B 6$ & 621 & 1150 & 10 & 14.31 & 116.1 & 801 & 125.7 & 867 & 5.8 & 11.5 \\
\hline 313A1 & 621 & 1150 & 20 & 14.58 & 106.7 & 736 & 117.8 & 812 & $\overline{6.1}$ & 13.0 \\
\hline 314A1 & 621 & 1150 & 40 & 14.85 & 101.2 & 698 & 113.8 & 785 & 6.6 & 13.3 \\
\hline $314 B 6$ & 621 & 1150 & 40 & 14.85 & 106.3 & 733 & 116.1 & 801 & 7.2 & 15.0 \\
\hline 32IA1 & 677 & 1250 & 5 & 14.91 & 103.3 & 712 & 114.1 & 787 & 6.2 & 12.4 \\
\hline 32186 & 677 & 1250 & 5 & 14.91 & 104.7 & 722 & 114.3 & 788 & 6.8 & $\overline{14.3}$ \\
\hline 322AI & 677 & 1250 & 10 & 15.20 & 95.2 & 656 & 106.9 & 737 & 6.4 & 14.2 \\
\hline $322 B 6$ & 677 & 1250 & 10 & 15.20 & 100.0 & 690 & 111.7 & 770 & 4.9 & 14.7 \\
\hline $323 \overline{A 1}$ & 677 & 1250 & 20 & 15.48 & 89.0 & 614 & 101.9 & 703 & 7.3 & 14.8 \\
\hline $324 \mathrm{Al}$ & 677 & 1250 & 40 & 15.77 & 69.6 & 480 & 91.4 & 630 & 7.3 & 13.0 \\
\hline 32486 & 677 & 1250 & 40 & 15.77 & 91.0 & 627 & 102.5 & 707 & 10.1 & 17.7 \\
\hline $331 \mathrm{AI}$ & 732 & 1350 & 5 & 15.78 & 103.9 & 716 & 164.0 & 1131 & 4.4 & 6.2 \\
\hline 33186 & 732 & 1350 & 5 & 15.78 & 104.5 & 721 & 162.4 & 1120 & 7.0 & 10.9 \\
\hline 332A1 & 732 & 1350 & 10 & 16.09 & 87.0 & 600 & 147.3 & 1016 & 6.9 & 11.9 \\
\hline $333 \mathrm{AI}$ & 732 & 1350 & 20 & 16.39 & 103.6 & 714 & 148.9 & 1027 & 5.6 & 9.7 \\
\hline $334 \mathrm{Al}$ & 732 & 1350 & 40 & 16.69 & 100.2 & 691 & 157.0 & 1083 & 6.1 & 11.0 \\
\hline $334 \mathrm{B6}$ & 732 & 1350 & 40 & 16.69 & 101.3 & 698 & 149.9 & 1034 & 7.0 & 12.1 \\
\hline $341 \mathrm{Al}$ & 788 & 1450 & 5 & 16.66 & 76.9 & 530 & 129.6 & 894 & 11.4 & 17.2 \\
\hline $342 \mathrm{AI}$ & 788 & 1450 & 10 & 16.97 & 75.2 & 519 & 130.8 & 902 & 10.5 & 16.0 \\
\hline 342B5 & 788 & 1450 & 10 & 16.97 & 69.0 & 476 & 122.0 & 841 & 10.4 & 15.9 \\
\hline $343 \mathrm{A1}$ & 788 & 1450 & 20 & 17.29 & 78.0 & 538 & 129.1 & 890 & 11.4 & $\overline{17.4}$ \\
\hline 34386 & 788 & 1450 & 20 & 17.29 & 73.1 & 504 & 122.9 & 847 & 12.7 & 17.6 \\
\hline $344 \mathrm{AI}$ & 788 & 1450 & 40 & 17.61 & 75.9 & 523 & 124.6 & 859 & 9.8 & 14.5 \\
\hline
\end{tabular}


Table B3. Continued

\begin{tabular}{|l|l|l|l|l|l|l|l|l|l|l|}
\hline $344 \mathrm{~B} 6$ & 788 & 1450 & 40 & 17.61 & 74.1 & 511 & 123.8 & 854 & 13.4 & 18.8 \\
\hline $351 \mathrm{~A} 1$ & 843 & 1550 & 5 & 17.53 & 73.5 & 507 & 124.8 & 860 & 9.5 & 12.1 \\
\hline $351 \mathrm{~B} 6$ & 843 & 1550 & 5 & 17.53 & 73.5 & 507 & 106.9 & 737 & 4.2 & 6.4 \\
\hline $352 \mathrm{~A} 1$ & 843 & 1550 & 10 & 17.86 & 68.8 & 474 & 118.8 & 819 & 8.1 & 12.3 \\
\hline $352 \mathrm{~B} 5$ & 843 & 1550 & 10 & 17.86 & 67.0 & 462 & 113.1 & 780 & 9.1 & 14.3 \\
\hline $353 \mathrm{~A} 1$ & 843 & 1550 & 20 & 18.20 & 64.0 & 441 & 101.2 & 698 & 5.1 & 10.1 \\
\hline $354 \mathrm{~A} 1$ & 843 & 1550 & 40 & 18.54 & 64.8 & 447 & 104.9 & 723 & 6.9 & 11.3 \\
\hline $361 \mathrm{~A} 1$ & 899 & 1650 & 5 & 18.40 & 74.3 & 512 & 118.8 & 819 & 7.0 & 11.9 \\
\hline $361 \mathrm{~B} 5$ & 899 & 1650 & 5 & 18.40 & 60.5 & 417 & 104.9 & 723 & 10.9 & 16.8 \\
\hline $362 \mathrm{~A} 1$ & 899 & 1650 & 10 & 18.75 & 72.1 & 497 & 119.6 & 825 & 8.4 & 12.5 \\
\hline $362 \mathrm{C1}$ & 899 & 1650 & 10 & 18.75 & 77.1 & 532 & 121.2 & 836 & 9.6 & 14.5 \\
\hline $363 \mathrm{A1}$ & 899 & 1650 & 20 & 19.11 & 69.7 & 481 & 103.1 & 711 & 5.6 & 11.2 \\
\hline $363 \mathrm{B6}$ & 899 & 1650 & 20 & 19.11 & 66.3 & 457 & 105.1 & 725 & 6.4 & 11.2 \\
\hline $364 \mathrm{A1}$ & 899 & 1650 & 40 & 19.46 & 70.0 & 483 & 112.7 & 777 & 6.4 & 10.3 \\
\hline $364 \mathrm{BJ}$ & 899 & 1650 & 40 & 19.46 & 63.5 & 438 & 103.1 & 711 & 9.0 & 14.8 \\
\hline
\end{tabular}

a AW - Ag-welded 
Table B4. Tensile data for weld 4, low-carbon FCA

\begin{tabular}{|c|c|c|c|c|c|c|c|c|c|c|}
\hline SPEC & \multicolumn{2}{|c|}{ ANa TEMPa } & \multirow{2}{*}{$\frac{\text { ANN TnuE }}{\text { (HR) }}$} & \multirow{2}{*}{$\frac{\text { T.P. }}{\left(\times 10^{-3}\right)}$} & \multicolumn{2}{|c|}{ TRED BTRENGT } & \multicolumn{2}{|c|}{ ULTMMATE STRENGTH } & \multirow{2}{*}{$\begin{array}{c}\text { UNF ELONG } \\
\text { (क) }\end{array}$} & \multirow{2}{*}{$\frac{\text { TOT ETONG }}{(\%)}$} \\
\hline ID & (०C) & T०F) & & & (ksi) & (MPa) & (ksi) & (MPa) & & \\
\hline $400 \overline{A 1}$ & $\overline{A W}$ & $\overline{\mathrm{AW}}$ & AW & 0 & 85.1 & 587 & 97.4 & 672 & 6.4 & 12.1 \\
\hline $400 \mathrm{B1}$ & $\overline{\mathrm{AW}}$ & $\overline{\mathrm{AW}}$ & $\overline{\mathrm{AW}}$ & 0 & 86.0 & 593 & 96.2 & $\overline{663}$ & 5.7 & 9.4 \\
\hline 411A1 & 621 & 1150 & 5 & 14.04 & 79.7 & 550 & 95.0 & 655 & 7.8 & 15.6 \\
\hline 41181 & 621 & 1150 & 5 & 14.04 & 77.0 & 531 & 92.0 & 634 & 9.0 & 15.7 \\
\hline 412A1 & 621 & 1150 & 10 & 14.31 & 78.4 & 541 & 91.8 & 633 & 8.7 & 16.5 \\
\hline $412 \mathrm{B1}$ & 621 & 1150 & 10 & 14.31 & 71.7 & 494 & 84.9 & 585 & 6.6 & 13.7 \\
\hline$4 \longdiv { 3 A 1 }$ & 621 & 1150 & 20 & 14.58 & 75.0 & 517 & 89.6 & 618 & 8.4 & 15.3 \\
\hline $413 \overline{B 1}$ & 621 & 1150 & 20 & 14.58 & 68.8 & 474 & 85.1 & 587 & $\overline{9.5}$ & 17.0 \\
\hline 414A1 & 621 & 1150 & 40 & 14.85 & 73.9 & 510 & 89.0 & 614 & 8.4 & 16.8 \\
\hline $414 \mathrm{BI}$ & 621 & 1150 & 40 & 14.85 & 70.7 & 487 & 84.4 & 582 & 10.9 & 18.6 \\
\hline $421 \mathrm{AI}$ & 677 & 1250 & 5 & 14.91 & 76.6 & 528 & 90.0 & 621 & 10.8 & 19.0 \\
\hline $421 B 1$ & 677 & 1250 & 5 & 14.91 & 71.7 & 494 & 85.9 & 592 & 9.0 & 17.6 \\
\hline $422 \mathrm{Al}$ & 677 & 1250 & 10 & 15.20 & 71.1 & 490 & 87.4 & 603 & 11.3 & 20.1 \\
\hline $422 \mathrm{B1}$ & 677 & 1250 & 10 & 15.20 & 63.0 & 434 & 79.1 & 545 & 10.3 & 17.5 \\
\hline $423 \mathrm{Al}$ & 677 & 1250 & 20 & 15.48 & 55.3 & 381 & 76.4 & 527 & $\overline{10.8}$ & 18.8 \\
\hline $423 B 1$ & 677 & 1250 & 20 & 15.48 & 54.7 & 377 & 74.6 & 514 & 10.4 & 18.4 \\
\hline $424 \mathrm{Al}$ & 677 & 1250 & 40 & 15.77 & 49.8 & 343 & 71.4 & 492 & 9.6 & 17.1 \\
\hline $424 \mathrm{BI}$ & 677 & 1250 & 40 & 15.77 & 49.2 & 339 & 71.5 & 493 & 12.1 & 21.1 \\
\hline $431 \mathrm{A1}$ & 732 & 1350 & 5 & 15.78 & 62.6 & 432 & 92.0 & 634 & 8.0 & 14.9 \\
\hline 43181 & 732 & 1350 & 5 & 15.78 & 58.3 & 402 & 88.6 & 611 & 10.0 & 17.3 \\
\hline $432 \mathrm{Al}$ & 732 & 1350 & 10 & 16.09 & 56.9 & 392 & 92.8 & 640 & 12.7 & 19.8 \\
\hline $432 \mathrm{B1}$ & 732 & 1350 & 10 & 16.09 & 51.8 & 357 & 87.2 & 601 & 11.4 & 17.9 \\
\hline 433A1 & 732 & 1350 & 20 & 16.39 & 56.9 & 392 & 91.0 & 627 & 11.3 & 17.8 \\
\hline $433 \overline{B 1}$ & 732 & 1350 & 20 & 16.39 & 51.9 & 358 & 82.7 & 570 & 13.0 & 22.1 \\
\hline $434 \mathrm{A1}$ & 732 & 1350 & 40 & 16.69 & 55.6 & 383 & 90.8 & 626 & 12.2 & 17.9 \\
\hline $434 \mathrm{BI}$ & 732 & 1350 & 40 & 16.69 & 50.4 & 348 & 81.7 & 563 & 10.6 & 18.4 \\
\hline $441 \mathrm{AI}$ & 788 & 1450 & 5 & 16.66 & 62.3 & 430 & 91.0 & 627 & 10.4 & 17.1 \\
\hline
\end{tabular}


Table B4. Continued

\begin{tabular}{|c|c|c|c|c|c|c|c|c|c|c|}
\hline 441B1 & 788 & 1450 & 5 & 16.66 & 56.2 & 387 & 79.5 & 548 & 10.8 & 18.4 \\
\hline $442 \mathrm{AI}$ & 788 & 1450 & 10 & 16.97 & 55.4 & 382 & 91.2 & 629 & 12.8 & 21.5 \\
\hline $442 \mathrm{~B} 1$ & 788 & 1450 & 10 & 16.97 & 50.7 & 350 & 83.1 & $5 \overline{73}$ & 11.3 & 18.5 \\
\hline 443A1 & 788 & 1450 & 20 & 17.29 & 56.8 & $\overline{392}$ & $\overline{89.2}$ & 615 & 14.4 & 23.1 \\
\hline 44381 & 788 & 1450 & 20 & 17.29 & 53.9 & 372 & 82.0 & 565 & 12.4 & 20.4 \\
\hline $44 \overline{A 1}$ & 788 & 1450 & 40 & 17.61 & 55.0 & 379 & 89.4 & 616 & 15.4 & 22.1 \\
\hline $444 \mathrm{BI}$ & 788 & 1450 & 40 & 17.61 & 49.2 & 339 & 79.7 & 550 & 11.5 & 17.9 \\
\hline $451 \mathrm{Al}$ & 843 & 1550 & 5 & 17.53 & 53.8 & 371 & 76.9 & 530 & 14.7 & 22.4 \\
\hline $451 \mathrm{B1}$ & 843 & 1550 & 5 & 17.53 & 49.4 & 341 & $7 \overline{73.1}$ & 504 & 17.2 & 25.8 \\
\hline $452 A 1$ & 843 & 1550 & 10 & 17.86 & 49.0 & $\overline{338}$ & 74.3 & 512 & 14.7 & 22.7 \\
\hline $452 \mathrm{B1}$ & 843 & 1550 & 10 & 17.86 & 46.9 & 323 & 71.4 & 492 & 16.9 & 26.2 \\
\hline $453 \mathrm{Al}$ & 843 & 1550 & 20 & 18.20 & 52.7 & 363 & 74.6 & 514 & 15.9 & 25.1 \\
\hline $453 \overline{B 1}$ & 843 & 1550 & 20 & 18.20 & 43.0 & 296 & 68.5 & 472 & 16.9 & 25.9 \\
\hline 454A1 & 843 & 1550 & 40 & 18.54 & 49.0 & $\overline{338}$ & 72.7 & 501 & 14.1 & 23.1 \\
\hline $454 \mathrm{B1}$ & 843 & 1550 & 40 & 18.54 & 43.8 & 302 & 67.7 & 467 & 15.9 & 25.0 \\
\hline 461A1 & 899 & 1650 & 5 & 18.40 & 44.4 & 306 & 70.8 & 488 & 16.3 & $\overline{26.9}$ \\
\hline $461 \overline{11}$ & 899 & 1650 & 5 & 18.40 & 41.9 & 289 & 65.4 & 451 & 16.1 & 248 \\
\hline $462 \mathrm{Al}$ & 899 & 1650 & 10 & 18.75 & $\overline{51.4}$ & 354 & 72.3 & 499 & 15.7 & $\overline{25.5}$ \\
\hline 46281 & 899 & 1650 & 10 & 18.75 & 45.5 & $\overline{314}$ & 67.6 & 466 & 18.3 & 25.5 \\
\hline $463 \mathrm{A1}$ & 899 & 1650 & 20 & 19.11 & 44.3 & 305 & 68.4 & 472 & 17.0 & 27.3 \\
\hline $463 \mathrm{B1}$ & 899 & 1650 & 20 & 19.11 & 41.4 & 285 & 64.2 & 443 & 14.8 & 23.5 \\
\hline $464 A 1$ & 899 & 1650 & 40 & 19.46 & 42.3 & 292 & 68.3 & 471 & 16.5 & 25.7 \\
\hline $464 \mathrm{B1}$ & 899 & 1650 & 40 & 19.46 & 40.4 & 279 & 65.0 & 448 & 17.5 & 27.2 \\
\hline
\end{tabular}

AW - As-welded 


\section{Appendix C}

\section{Charpy Impact Data for Welds 1 Through 4}

\section{Note:}

Set names identify the weld and heat treatment given.

\section{Examples:}

1 AW: Weld 1, as-welded

2_20_1650: Weld 2, $20 \mathrm{~h}$ at $1650^{\circ} \mathrm{F}$ 
Table C1. Charpy impact data for weld 1, low-carbon SMA

SOURCE: ANALYSIS SET

ANALYSIS SETS
1_AW
1_5_1150
$1+10-1150$

SET NAME: 1 AW

REMARK: NON $\bar{E}$

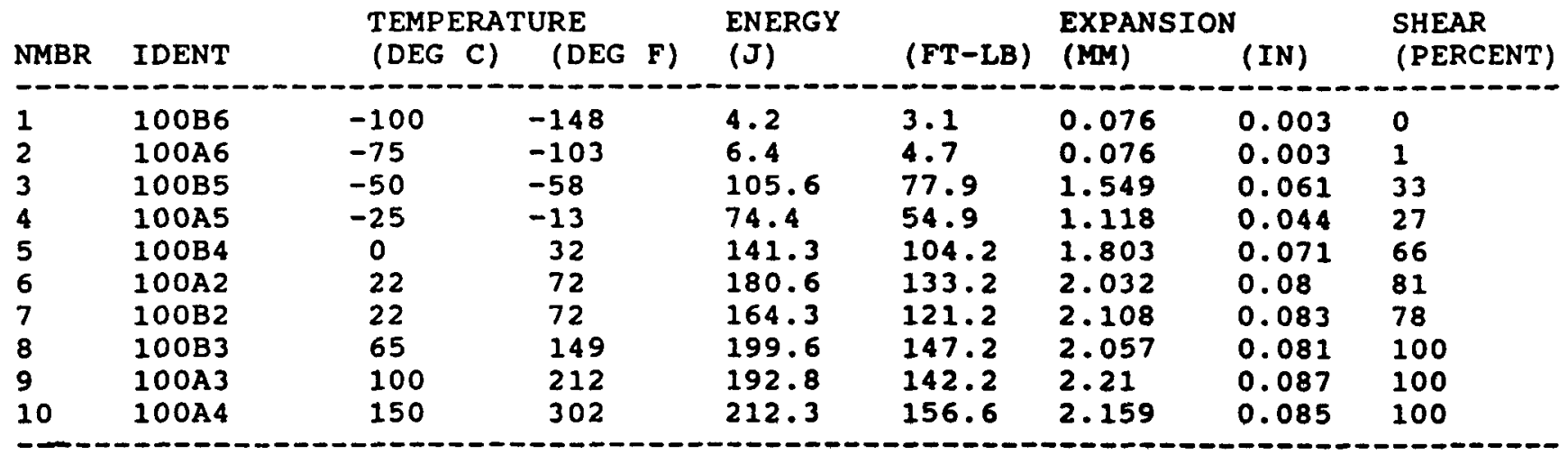

SET NAME: 1 5_1150

REMARK: NON $\bar{E}-$

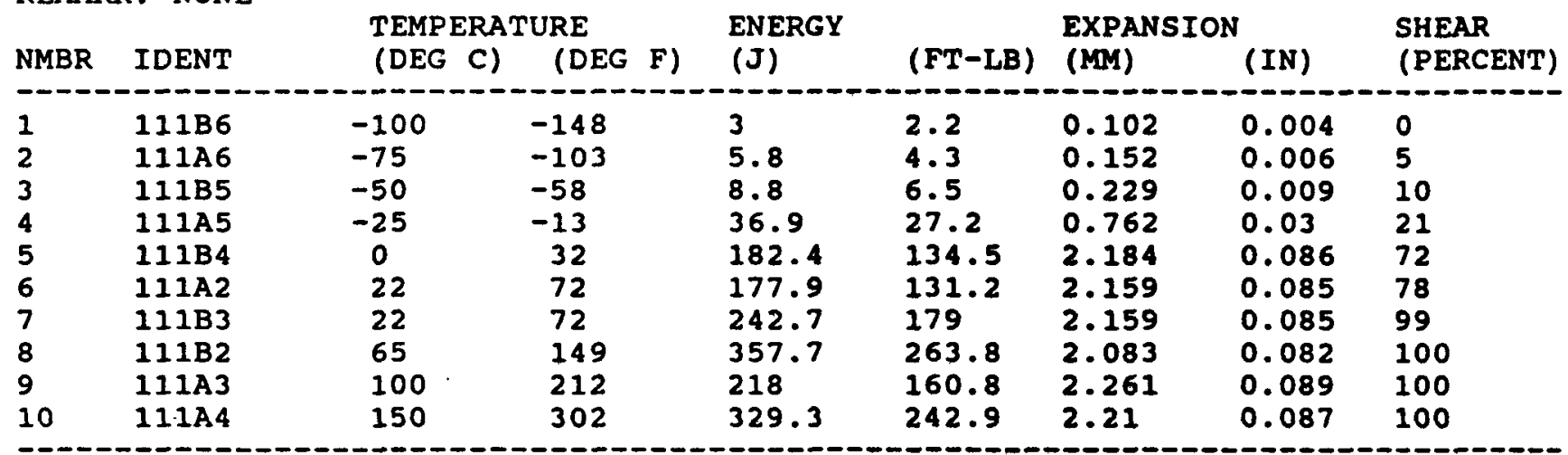

SET NAME: 1 10_1150

REMARK: NON $\bar{E}$

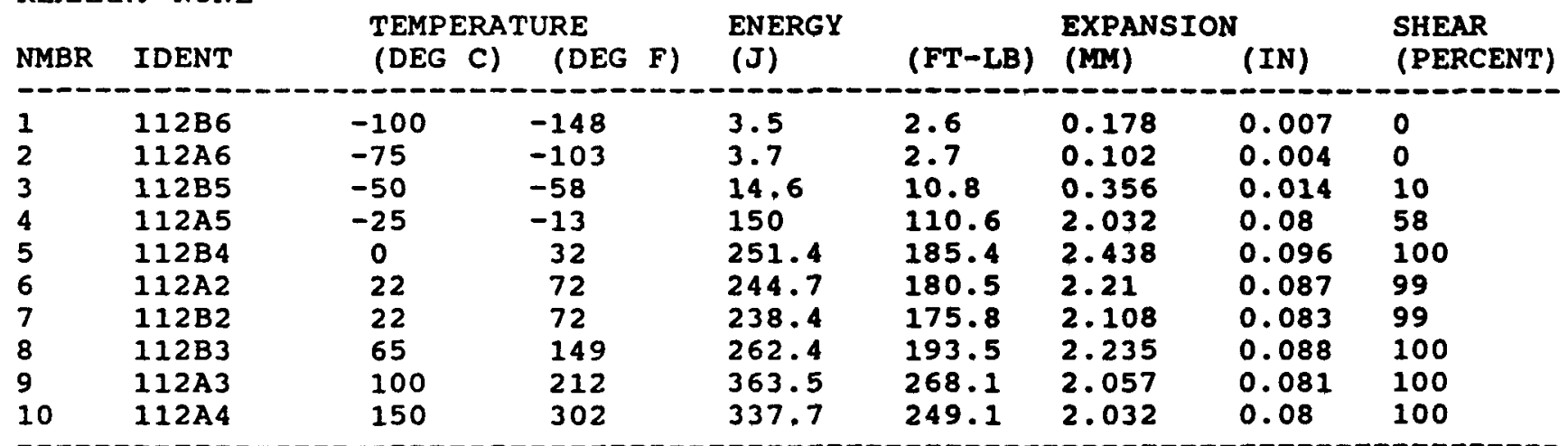


SOURCE: ANALYSIS SET

ANALYSIS SETS

$$
\text { 1_20_1150 1_40_1150 1_5_1250 }
$$

SET NAME: 1_20_1150

REMARK: NONE $\bar{E}$

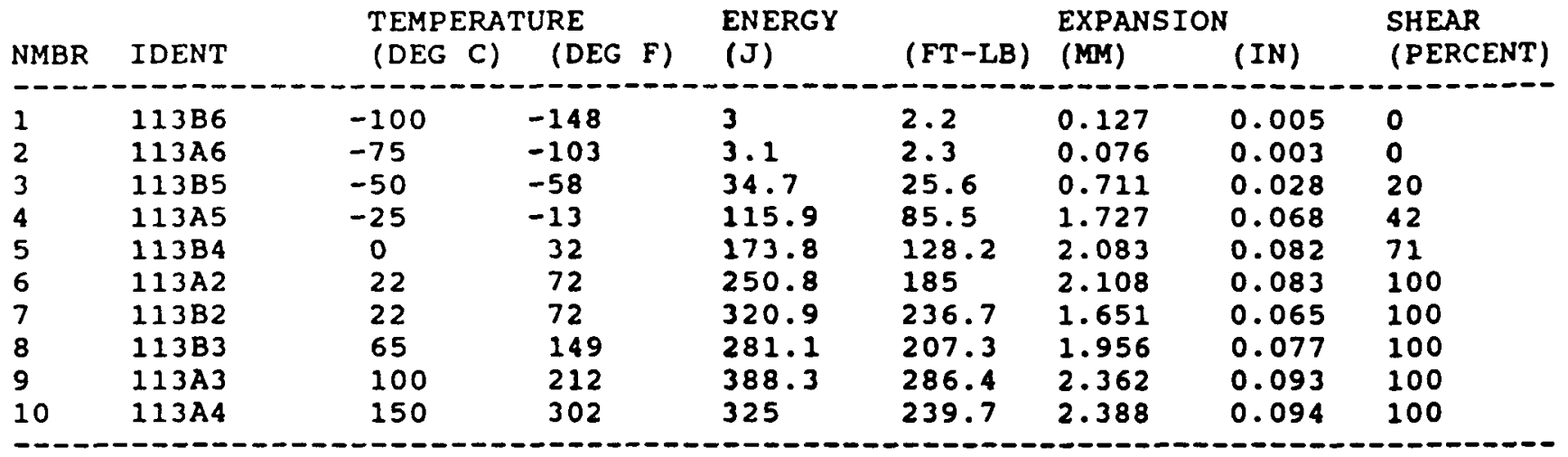

SET NAME: 1_40_1150

REMARK: NON $\bar{E}$

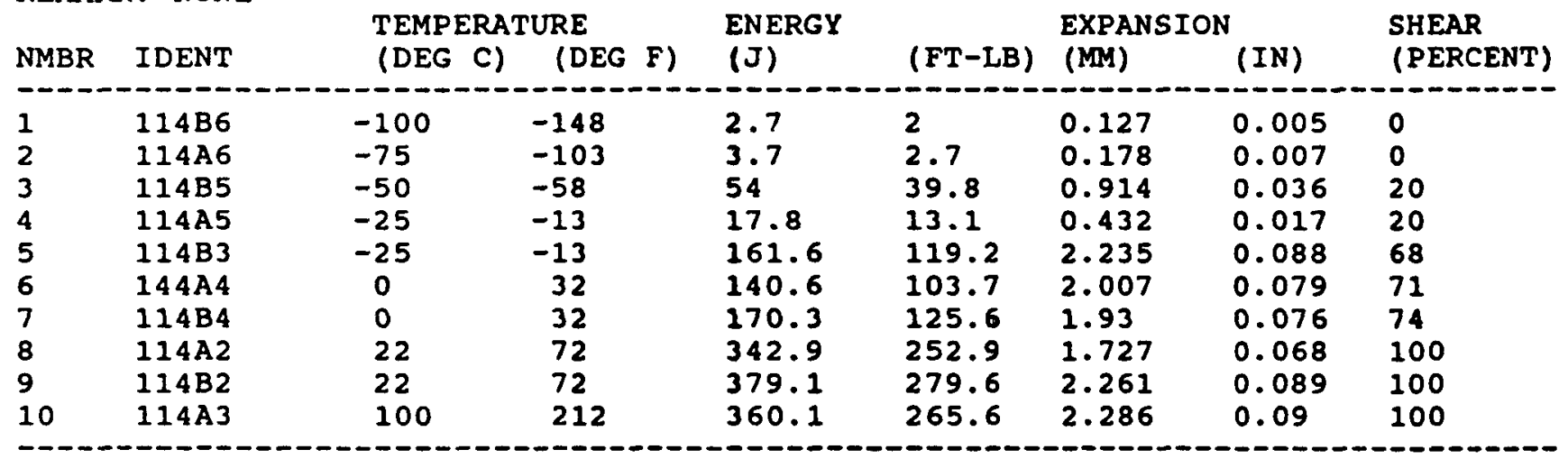

SET NAME: 1_5_1250

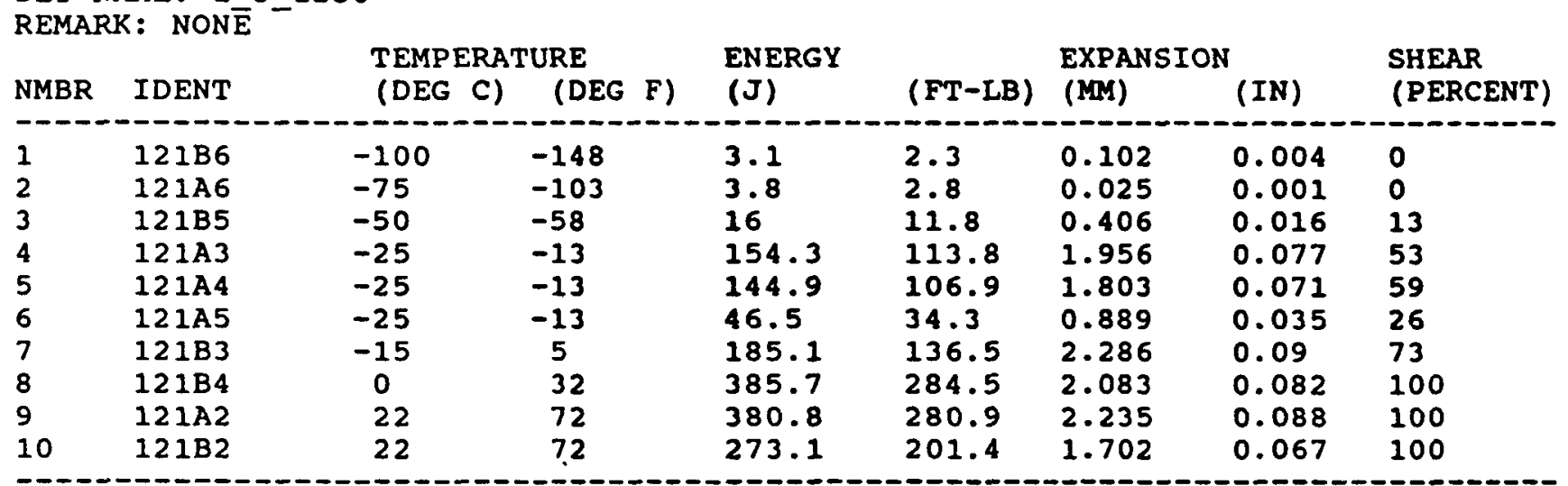


SOURCE: ANALYSIS SET

ANALYSIS SETS

$$
\text { 1_10_1250 1_20_1250 1_10_1350 }
$$

SET NAME: 1_10_1250

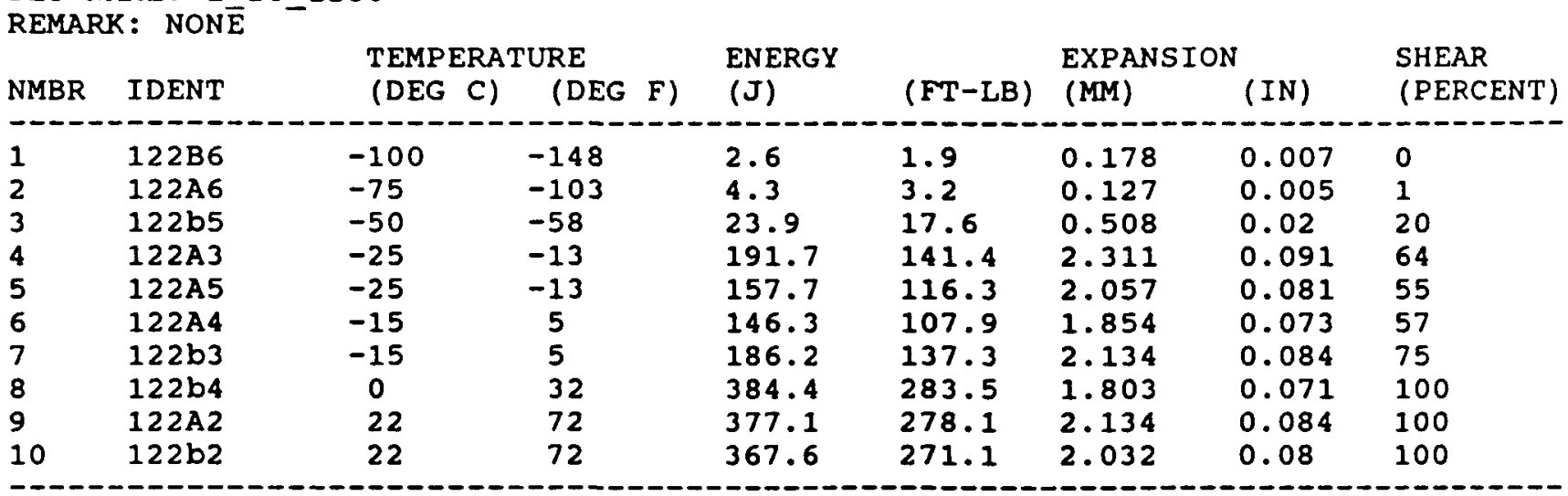

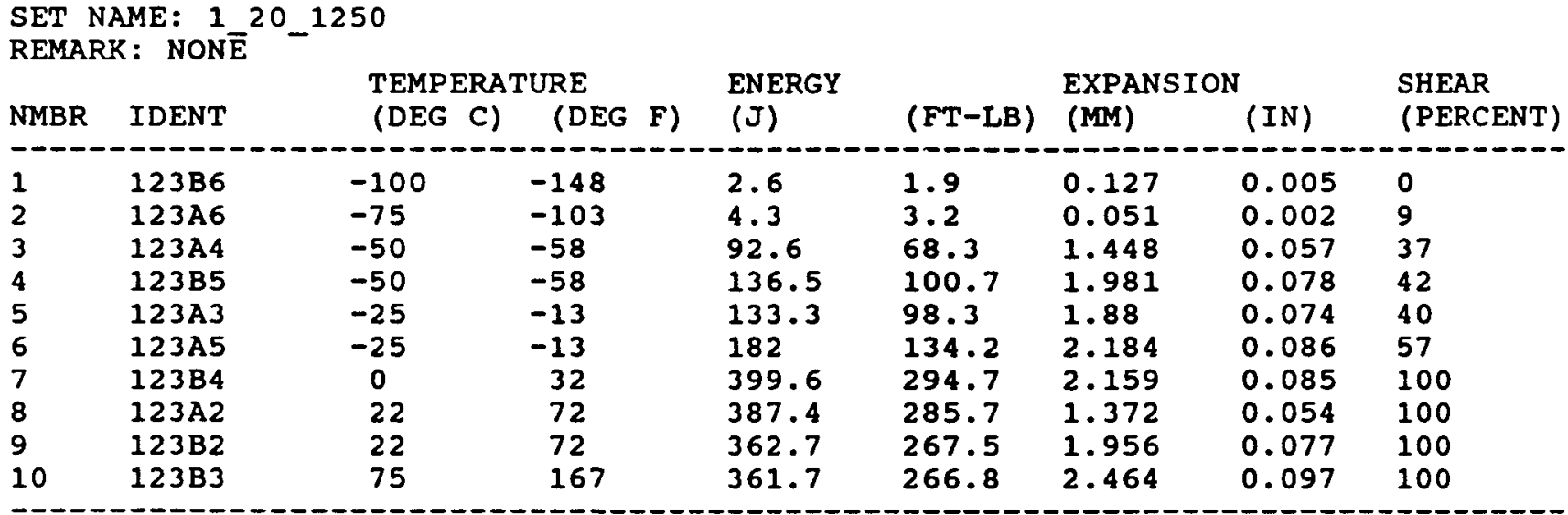

SET NAME: 1 10_1350

REMARK: NON $\bar{E}$

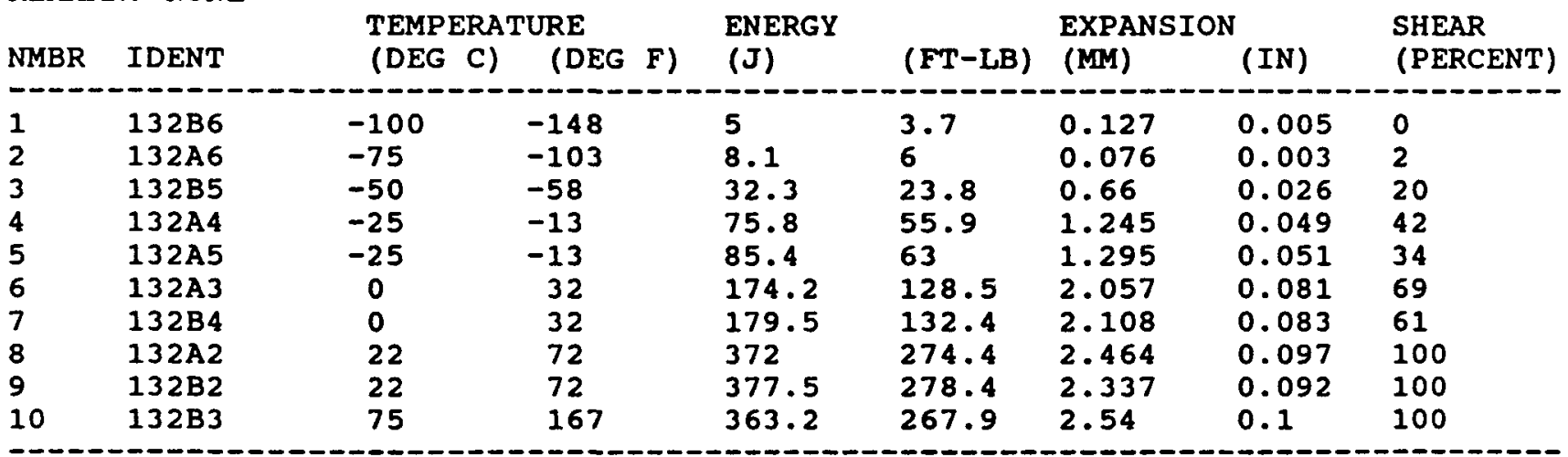


SOURCE: ANALYSIS SET

ANALYSIS SETS

$$
\text { 1_20_1350 1_40_1250 1_5_1350 }
$$

SET NAME: 1_20_1350

REMARK: NON $\bar{E}$

\begin{tabular}{|c|c|c|c|c|c|c|c|c|}
\hline NMBR & IDENT & $\begin{array}{l}\text { TEMPERA' } \\
\left(\begin{array}{ll}\text { DEG } & \text { C) }\end{array}\right.\end{array}$ & $\begin{array}{l}\text { rURE } \\
\text { (DEG F) }\end{array}$ & $\begin{array}{l}\text { ENERGY } \\
(\mathrm{J})\end{array}$ & $(F T-L B)$ & $\begin{array}{l}\text { EXPANSION } \\
\text { (MM) }\end{array}$ & $(I N)$ & $\begin{array}{l}\text { SHEAR } \\
\text { (PERCENT) }\end{array}$ \\
\hline 1 & $133 \mathrm{~B} 6$ & -100 & -148 & 5.7 & 4.2 & 0.102 & 0.004 & 1 \\
\hline 2 & $133 \mathrm{~A} 6$ & -75 & -103 & 6.1 & 4.5 & 0.102 & 0.004 & 5 \\
\hline 3 & $133 B 5$ & -50 & -58 & 25.6 & 18.9 & 0.483 & 0.019 & 18 \\
\hline 4 & $133 A 3$ & -25 & -13 & 83.4 & 61.5 & 1.118 & 0.044 & 49 \\
\hline 5 & $133 A 5$ & -25 & -13 & 45.7 & 33.7 & 0.737 & 0.029 & 30 \\
\hline 6 & $133 \mathrm{A4}$ & -15 & 5 & 156.3 & 115.3 & 2.057 & 0.081 & 54 \\
\hline 7 & $133 \mathrm{~B} 4$ & 0 & 32 & 389.1 & 287 & 2.54 & 0.1 & 100 \\
\hline 8 & $133 \mathrm{~A} 2$ & 22 & 72 & 377.3 & 278.3 & 2.413 & 0.095 & 100 \\
\hline 9 & $133 \mathrm{~B} 2$ & 22 & 72 & 384.5 & 283.6 & 2.464 & 0.097 & 100 \\
\hline 10 & $133 B 3$ & 75 & 167 & 357.3 & 263.5 & 2.692 & 0.106 & 100 \\
\hline
\end{tabular}

SET NAME: 1 40_1250

REMARK: NON $\bar{E}$

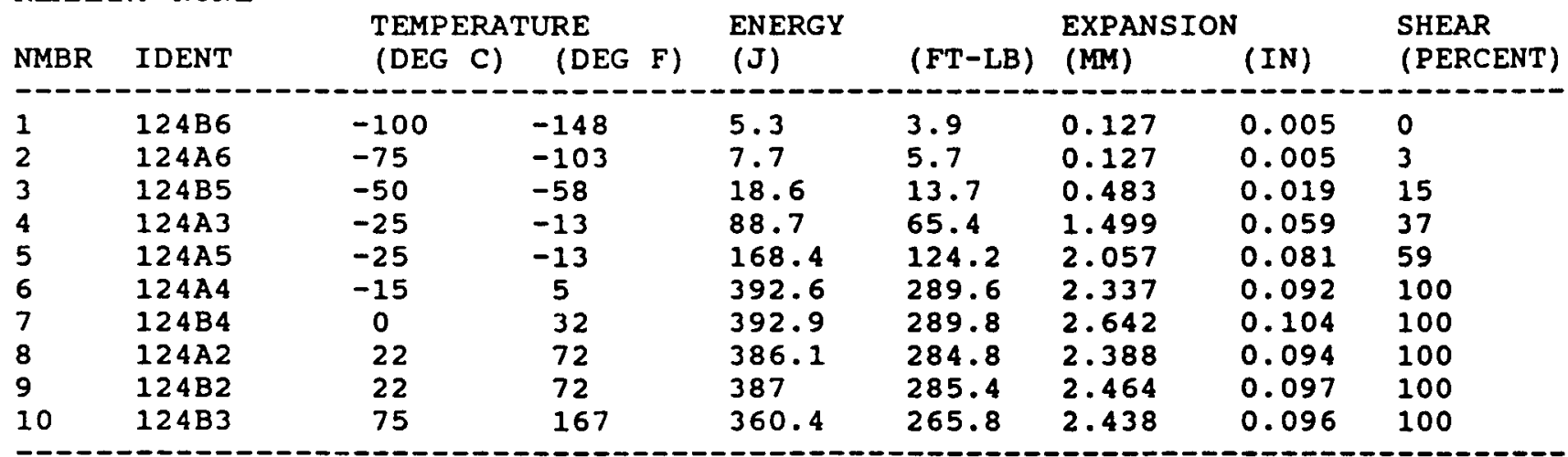

SET NAME: 1_5_1350

REMARK: NON $\bar{E}$

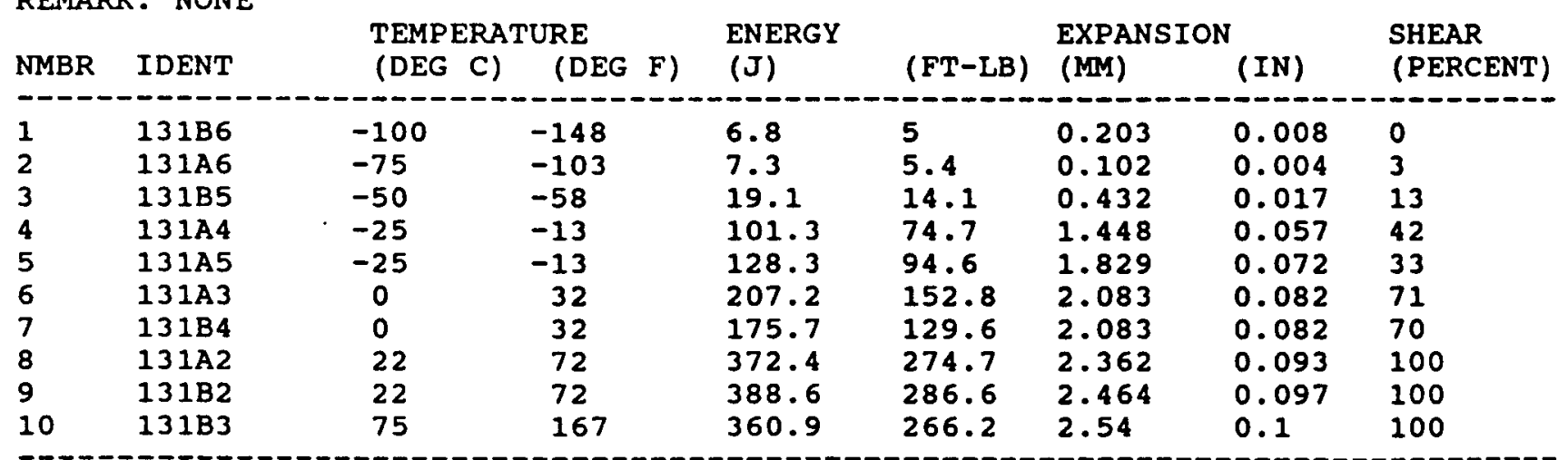


Table C1. Continued

SOURCE: ANALYSIS SET

ANALYSIS SETS

1_10_1450 1_20_1450 1_40_1350

SET NAME: 1_10_1450

REMARK: NON $\bar{E}$

\begin{tabular}{|c|c|c|c|c|c|c|c|c|}
\hline NMBR & IDENT & $\begin{array}{l}\text { TEMPERAT } \\
\left(\begin{array}{ll}\text { DEG }\end{array}\right.\end{array}$ & $\begin{array}{l}\text { TURE } \\
\text { (DEG F) }\end{array}$ & $\begin{array}{l}\text { ENERGY } \\
\text { (J) }\end{array}$ & $(\mathrm{FT}-\mathrm{LB})$ & $\begin{array}{l}\text { EXPANSION } \\
\text { (MM) }\end{array}$ & (IN) & $\begin{array}{l}\text { SHEAR } \\
\text { (PERCENT) }\end{array}$ \\
\hline 1 & $142 \mathrm{~B} 6$ & -100 & -148 & 5.6 & 4.1 & 0.102 & 0.004 & 0 \\
\hline 2 & $142 \mathrm{~A} 6$ & -75 & -103 & 9.9 & 7.3 & 0.127 & 0.005 & 0 \\
\hline 3 & 142 B5 & -50 & -58 & 21.7 & 16 & 0.508 & 0.02 & 21 \\
\hline 4 & $142 \mathrm{~A} 5$ & -25 & -13 & 57.4 & 42.3 & 0.838 & 0.033 & 40 \\
\hline 5 & $142 \mathrm{~B} 3$ & -25 & -13 & 48.7 & 35.9 & 0.991 & 0.039 & 34 \\
\hline 6 & $142 \mathrm{~A} 4$ & 0 & 32 & 150.9 & 111.3 & 1.93 & 0.076 & 60 \\
\hline 7 & $142 B 4$ & 0 & 32 & 85 & 62.7 & 1.372 & 0.054 & 46 \\
\hline 8 & 142A2 & 22 & 72 & 199.8 & 147.4 & 2.489 & 0.098 & 65 \\
\hline 9 & $142 \mathrm{~B} 2$ & 22 & 72 & 372.6 & 274.8 & 2.565 & 0.101 & 100 \\
\hline 10 & $142 \mathrm{~A} 3$ & 75 & 167 & 351.2 & 259 & 2.515 & 0.099 & 100 \\
\hline
\end{tabular}

SET NAME: 1 20_1450

REMARK: NON $\bar{E}$

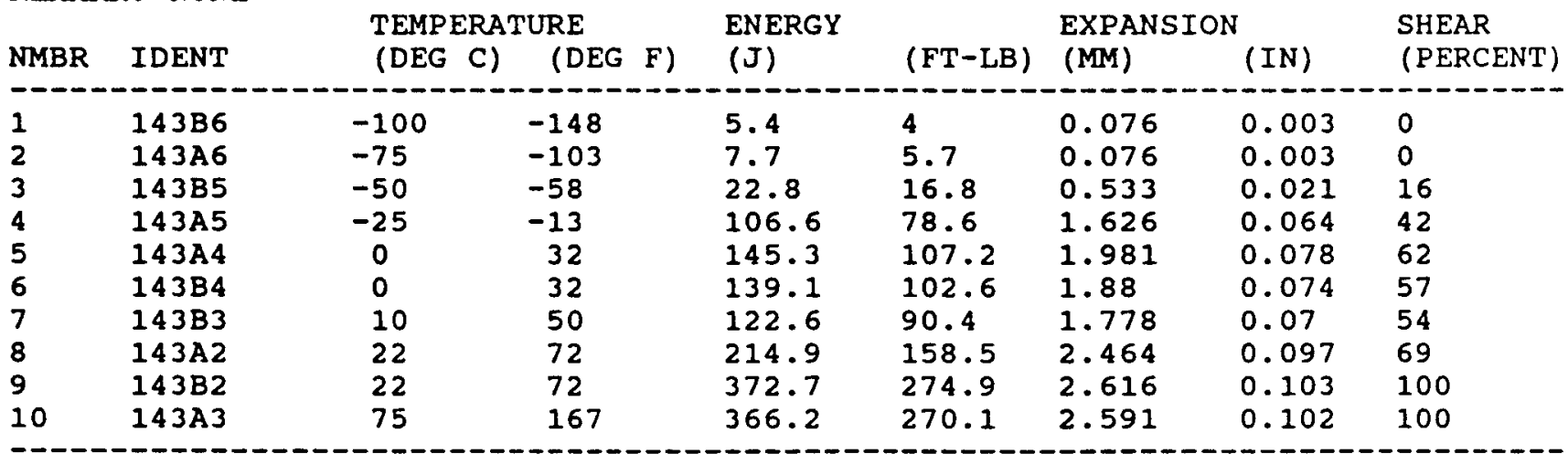

SET NAME: 1 40_1350

REMARK: NON $\bar{E}$

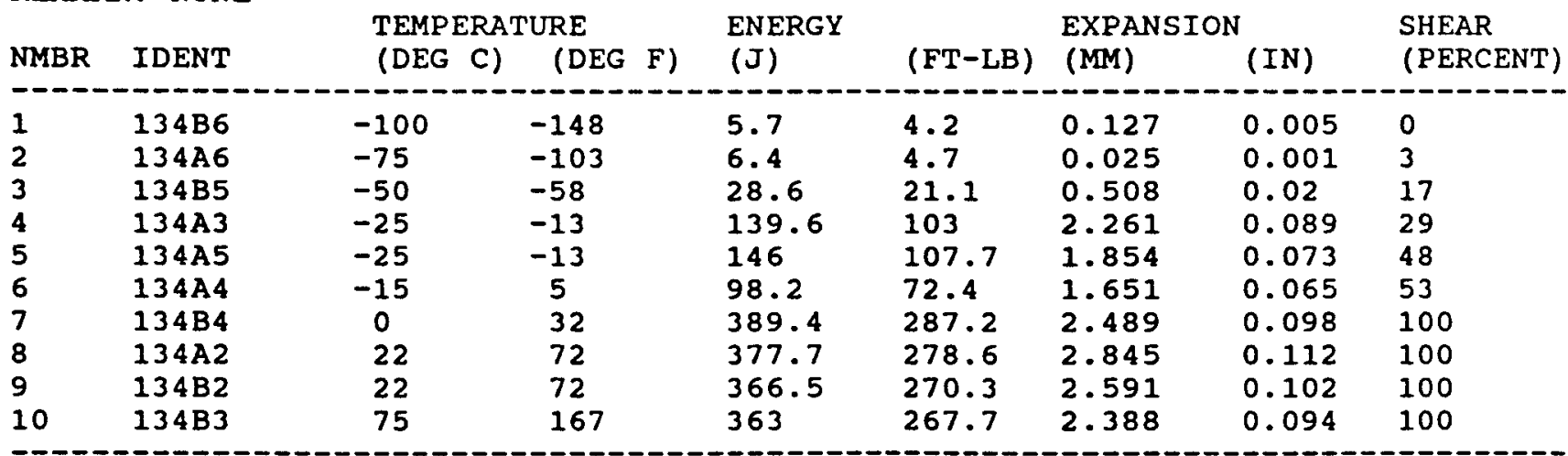


Table C1. Continued

SOURCE: ANALYSIS SET

ANALYSIS SETS

$$
\text { 1_5_1450 1_40_1450 1_5_1550 }
$$

SET NAME: 1 5 1450

REMARK: NON $\bar{E}-$

\begin{tabular}{|c|c|c|c|c|c|c|c|c|}
\hline NMBR & IDENT & $\begin{array}{l}\text { TEMPERA } \\
\text { (DEG C) }\end{array}$ & $\begin{array}{l}\text { IURE } \\
\text { (DEG F) }\end{array}$ & $\begin{array}{l}\text { ENERGY } \\
\text { (J) }\end{array}$ & $(F T-L B)$ & $\begin{array}{l}\text { EXPANSION } \\
\text { (MM) }\end{array}$ & (IN) & $\begin{array}{l}\text { SHEAR } \\
\text { (PERCENT) }\end{array}$ \\
\hline 1 & $141 \mathrm{~B} 6$ & -100 & -148 & 7.1 & 5.2 & 0.178 & 0.007 & 0 \\
\hline 2 & $141 \mathrm{~A} 6$ & -75 & -103 & 5.4 & 4 & 0.051 & 0.002 & 0 \\
\hline 3 & 14185 & -45 & -49 & 29.6 & 21.8 & 0.635 & 0.025 & 25 \\
\hline 4 & $141 \mathrm{~A} 3$ & -25 & -13 & 77.4 & 57.1 & 1.295 & 0.051 & 34 \\
\hline 5 & $141 \mathrm{~A} 5$ & -25 & -13 & 136.9 & 101 & 1.854 & 0.073 & 44 \\
\hline 6 & $141 A 4$ & 0 & 32 & 99.7 & 73.5 & 1.626 & 0.064 & 50 \\
\hline 7 & $141 \mathrm{~B} 4$ & 0 & 32 & 155.6 & 114.8 & 1.956 & 0.077 & 54 \\
\hline 8 & $141 \mathrm{~A} 2$ & 22 & 72 & 387.2 & 285.6 & 2.515 & 0.099 & 100 \\
\hline 9 & $141 \mathrm{B2}$ & 22 & 72 & 373.9 & 275.8 & 2.464 & 0.097 & 100 \\
\hline 10 & $141 \mathrm{~B} 3$ & 75 & 167 & 370.4 & 273.2 & 2.311 & 0.091 & 100 \\
\hline
\end{tabular}

SET NAME: 1_40_1450

\begin{tabular}{|c|c|c|c|c|c|c|c|c|}
\hline NMBR & IDENT & $\begin{array}{l}\text { TEMPERA } \\
\text { (DEG C) }\end{array}$ & $\begin{array}{l}\text { TURE } \\
\text { (DEG F) }\end{array}$ & $\begin{array}{l}\text { ENERGY } \\
(\mathrm{J})\end{array}$ & $(F T-L B)$ & $\begin{array}{l}\text { EXPANSION } \\
\text { (MM) }\end{array}$ & (IN) & $\begin{array}{l}\text { SHEAR } \\
\text { (PERCENT) }\end{array}$ \\
\hline 1 & $144 \mathrm{~B} 6$ & -100 & -148 & 4.3 & 3.2 & 0.076 & 0.003 & 0 \\
\hline 2 & $144 \mathrm{~A} 6$ & -75 & -103 & 3.7 & 2.7 & 0.076 & 0.003 & 0 \\
\hline 3 & $144 \mathrm{B5}$ & -50 & -58 & 21.2 & 15.6 & 0.533 & 0.021 & 16 \\
\hline 4 & $144 \mathrm{~A} 3$ & -25 & -13 & 29 & 21.4 & 0.686 & 0.027 & 23 \\
\hline 5 & $144 A 5$ & -25 & -13 & 66.4 & 49 & 1.118 & 0.044 & 48 \\
\hline 6 & $144 \mathrm{A4}$ & -15 & 5 & 61.4 & 45.3 & 1.168 & 0.046 & 36 \\
\hline 7 & $144 \mathrm{~B} 4$ & 0 & 32 & 397 & 292.8 & 2.718 & 0.107 & 100 \\
\hline 8 & $144 \mathrm{~A} 2$ & 22 & 72 & 374.7 & 276.4 & 2.692 & 0.106 & 100 \\
\hline 9 & $144 \mathrm{~B} 2$ & 22 & 72 & 378.5 & 279.2 & 2.616 & 0.103 & 100 \\
\hline 10 & $144 \mathrm{~B} 3$ & 75 & 167 & 360.9 & 266.2 & 2.413 & 0.095 & 100 \\
\hline
\end{tabular}

SET NAME: 1 5_1550

REMARK: NON $\vec{E}$

\begin{tabular}{|c|c|c|c|c|c|c|c|c|}
\hline NMBR & IDENT & $\begin{array}{l}\text { TEMPERA' } \\
\left(\begin{array}{ll}\text { (DEG } & \text { C) }\end{array}\right.\end{array}$ & $\begin{array}{l}\text { RURE } \\
\text { (DEG F) }\end{array}$ & $\begin{array}{l}\text { ENERGY } \\
\text { (J) }\end{array}$ & $(F T-L B)$ & $\begin{array}{l}\text { EXPANSION } \\
\text { (MM) }\end{array}$ & (IN) & $\begin{array}{l}\text { SHEAR } \\
\text { (PERCENT) }\end{array}$ \\
\hline 1 & 151B6 & -100 & -148 & 3.5 & 2.6 & 0.305 & 0.012 & 0 \\
\hline 2 & $151 \mathrm{~A} 6$ & -75 & -103 & 11.5 & 8.5 & 0.203 & 0.008 & 9 \\
\hline 3 & 151B5 & -50 & -58 & 32.9 & 24.3 & 0.686 & 0.027 & 19 \\
\hline 4 & $151 \mathrm{~A} 4$ & -35 & -31 & 112 & 82.6 & 1.676 & 0.066 & 36 \\
\hline 5 & 151B3 & -35 & -31 & 53.1 & 39.2 & 0.914 & 0.036 & 33 \\
\hline 6 & $151 \mathrm{~A} 3$ & -25 & -13 & 388.8 & 286.8 & 2.413 & 0.095 & 100 \\
\hline 7 & 151A5 & -25 & -13 & 397.3 & 293 & 2.489 & 0.098 & 100 \\
\hline 8 & 151B4 & 0 & 32 & 400.4 & 295.3 & 2.54 & 0.1 & 100 \\
\hline 9 & 151A2 & 22 & 72 & 383.6 & 282.9 & 2.413 & 0.095 & 100 \\
\hline 10 & $151 \mathrm{~B} 2$ & 22 & 72 & 370.8 & 273.5 & 2.464 & 0.097 & 100 \\
\hline
\end{tabular}


Table C1. Continued

SOURCE: ANALYSIS SET

ANALYSIS SETS

$$
\text { 1_10_1550 1_20_1550 1_20_1650 }
$$

SET NAME: 1 10 1550

REMARK : NON $\bar{E}$

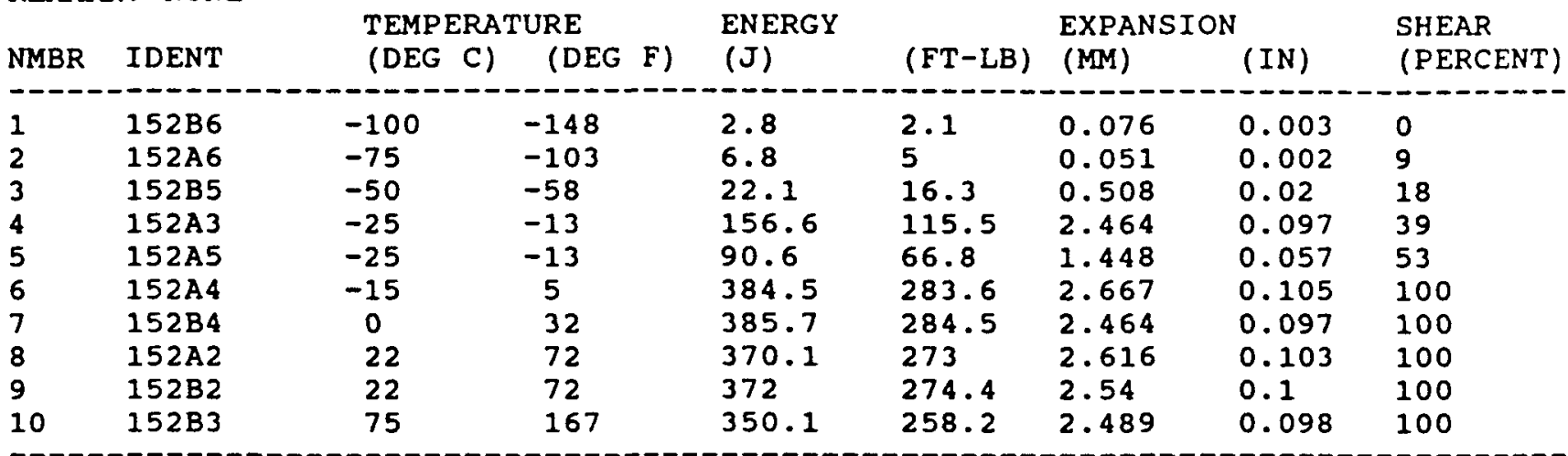

SET NAME: 1 20 1550

REMARK： NONE

\begin{tabular}{|c|c|c|c|c|c|c|c|c|}
\hline NMBR & IDENT & $\begin{array}{l}\text { TEMPERAT } \\
\text { (DEG C) }\end{array}$ & $\begin{array}{l}\text { CURE } \\
\text { (DEG F) }\end{array}$ & $\begin{array}{l}\text { ENERGY } \\
\text { (J) }\end{array}$ & $(F T-L B)$ & $\begin{array}{l}\text { EXPANSION } \\
\text { (MM) }\end{array}$ & (IN) & $\begin{array}{l}\text { SHEAR } \\
\text { (PERCENT) }\end{array}$ \\
\hline 1 & 153B6 & -100 & -148 & 4.5 & 3.3 & 0.229 & 0.009 & 0 \\
\hline 2 & $153 \mathrm{~A} 6$ & -75 & -103 & 3.8 & 2.8 & 0.076 & 0.003 & 0 \\
\hline 3 & 153B5 & -50 & -58 & 40.4 & 29.8 & 0.864 & 0.034 & 28 \\
\hline 4 & $153 \mathrm{~A} 3$ & -35 & -31 & 103.3 & 76.2 & 1.575 & 0.062 & 53 \\
\hline 5 & $153 \mathrm{~A} 4$ & -35 & -31 & 93.1 & 68.7 & 1.549 & 0.061 & 43 \\
\hline 6 & $153 A 5$ & -25 & -13 & 385.9 & 284.6 & 2.819 & 0.111 & 100 \\
\hline 7 & $153 \mathrm{~B} 4$ & 0 & 32 & 392.5 & 289.5 & 2.54 & 0.1 & 100 \\
\hline 8 & $153 \mathrm{A2}$ & 22 & 72 & 365.9 & 269.9 & 2.565 & 0.101 & 100 \\
\hline 9 & $153 \mathrm{~B} 2$ & 22 & 72 & 365 & 269.2 & 2.54 & 0.1 & 100 \\
\hline 10 & $153 \mathrm{~B} 3$ & 75 & 167 & 360.4 & 265.8 & 2.565 & 0.101 & 100 \\
\hline
\end{tabular}

SET NAME: $1220 \quad 1650$

REMARK: NON $\bar{E}$

\begin{tabular}{|c|c|c|c|c|c|c|c|c|}
\hline NMBR & IDENT & $\begin{array}{l}\text { TEMPERA? } \\
\text { (DEG C) }\end{array}$ & $\begin{array}{l}\text { TURE } \\
\text { (DEG F) }\end{array}$ & $\begin{array}{l}\text { ENERGY } \\
\text { (J) }\end{array}$ & $(F T-L B)$ & $\begin{array}{l}\text { EXPANSION } \\
\text { (MM) }\end{array}$ & (IN) & $\begin{array}{l}\text { SHEAR } \\
\text { (PERCENT) }\end{array}$ \\
\hline 1 & $163 \mathrm{A3}$ & -50 & -58 & 12.5 & 9.2 & 0.343 & 0.0135 & 11 \\
\hline$\overline{2}$ & $163 \mathrm{~A} 4$ & -25 & -13 & 12.6 & 9.3 & 0.394 & 0.0155 & 13 \\
\hline 3 & $163 A 5$ & -15 & 5 & 25.9 & 19.1 & 0.622 & 0.0245 & 29 \\
\hline 4 & $163 \mathrm{~A} 6$ & -10 & 14 & 29.7 & 21.9 & 0.521 & 0.0205 & 30 \\
\hline 5 & $163 \mathrm{B4}$ & -8 & 18 & 74.6 & 55 & 1.308 & 0.0515 & 30 \\
\hline 6 & $163 \mathrm{B2}$ & -5 & 23 & 357.4 & 263.6 & 2.413 & 0.095 & 100 \\
\hline 7 & $163 \mathrm{A2}$ & 0 & 32 & 366.3 & 270.2 & 2.54 & 0.1 & 100 \\
\hline 8 & $163 \mathrm{B3}$ & 25 & 77 & 351.7 & 259.4 & 2.311 & 0.091 & 100 \\
\hline 9 & $163 B 5$ & 100 & 212 & 328.4 & 242.2 & 2.337 & 0.092 & 100 \\
\hline
\end{tabular}


SOURCE: ANALYSIS SET

ANALYSIS SETS

$$
1 \text { 10_1550 1_5_1650 1_10_1650 }
$$

SET NAME: 1 40_1550

REMARK: NON $\bar{E}$

TEMPERATURE

NMBR IDENT

\begin{tabular}{ll}
\hline 1 & $154 \mathrm{A4}$ \\
2 & $154 \mathrm{B2}$ \\
3 & $154 \mathrm{~B} 4$ \\
4 & $154 \mathrm{A3}$ \\
5 & $154 \mathrm{~B} 5$ \\
6 & $154 \mathrm{B3}$ \\
7 & $154 \mathrm{~A} 6$ \\
8 & $154 \mathrm{A5}$ \\
9 & $154 \mathrm{A2}$ \\
10 & $154 \mathrm{~B} 6$
\end{tabular}

(DEG C)

$\begin{array}{ll}-100 & -148 \\ -75 & -103 \\ -60 & -76 \\ -50 & -58 \\ -50 & -58 \\ -40 & -40 \\ -25 & -13 \\ 0 & 32 \\ 25 & 77 \\ 100 & 212\end{array}$

(DEG F)

SET NAME: 1 5_1650

REMARK: NON $\bar{E}$

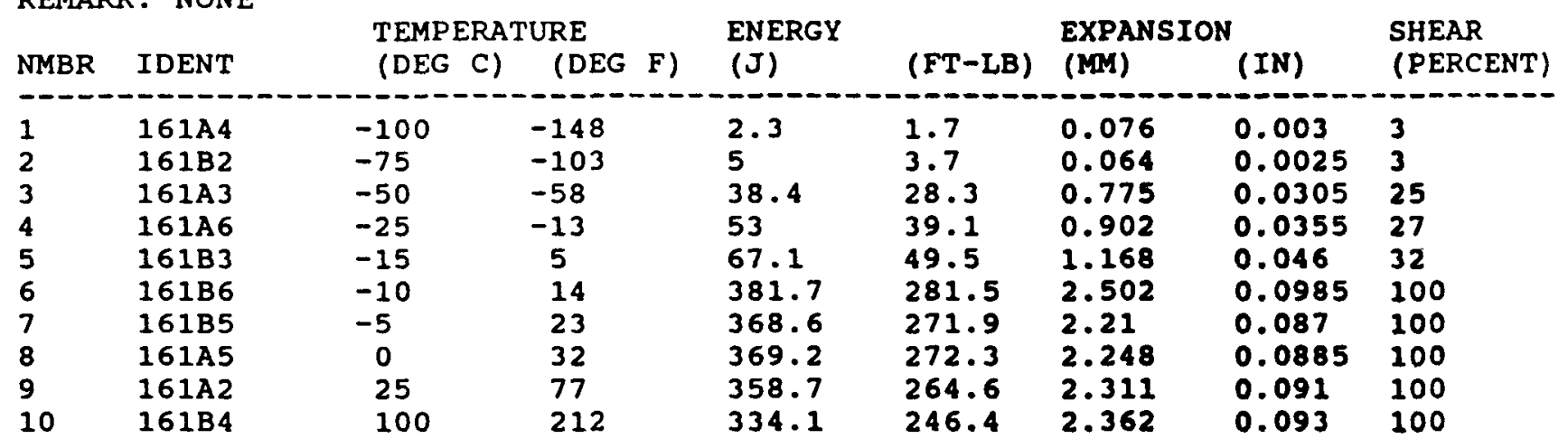

SET NAME: 1 10_1650

REMARK: NON $\bar{E}$

TEMPERATURE

NMBR IDENT

(DEG C)

$\begin{array}{lll}1 & 162 \mathrm{~A} 4 & -7 \\ 2 & 162 \mathrm{A3} & -5 \\ 3 & 162 \mathrm{~A} 5 & -2 \\ 4 & 162 \mathrm{~B} 5 & -2 \\ 5 & 162 \mathrm{~A} 6 & -1 \\ 6 & 162 \mathrm{~B} 6 & -1 \\ 7 & 162 \mathrm{~B} 4 & -1 \\ 8 & 162 \mathrm{A2} & 0 \\ 9 & 162 \mathrm{B3} & 25 \\ 10 & 162 \mathrm{B2} & 1 \\ - & & \end{array}$

(DEG C) (DEG F)

ENERGY

(J)

3.7

38.5

35.3

83.5

130.7

377.9

379.8

372.2

359.2

324.2

EXPANSION (FT-LB) (MM)

(IN)

2.7

28.4

26

61.6

96.4

278.7

280.1

274.5

264.9

239.1
EXPANSION

(IN)

0.00353

0.00553

0.016518

0.06227

0.02120

0.026520

0.03548

$0.098 \quad 100$

$0.107 \quad 100$

0.1105100
SHEAR

(PERCENT)

$-----$

8
18
0
8
100
100
100


Table C1. Continued

SOURCE: ANALYSIS SET

ANALYSIS SET: 1_40_1650

SET NAME: 1_40_1650

REMARK : NON $\vec{E}$

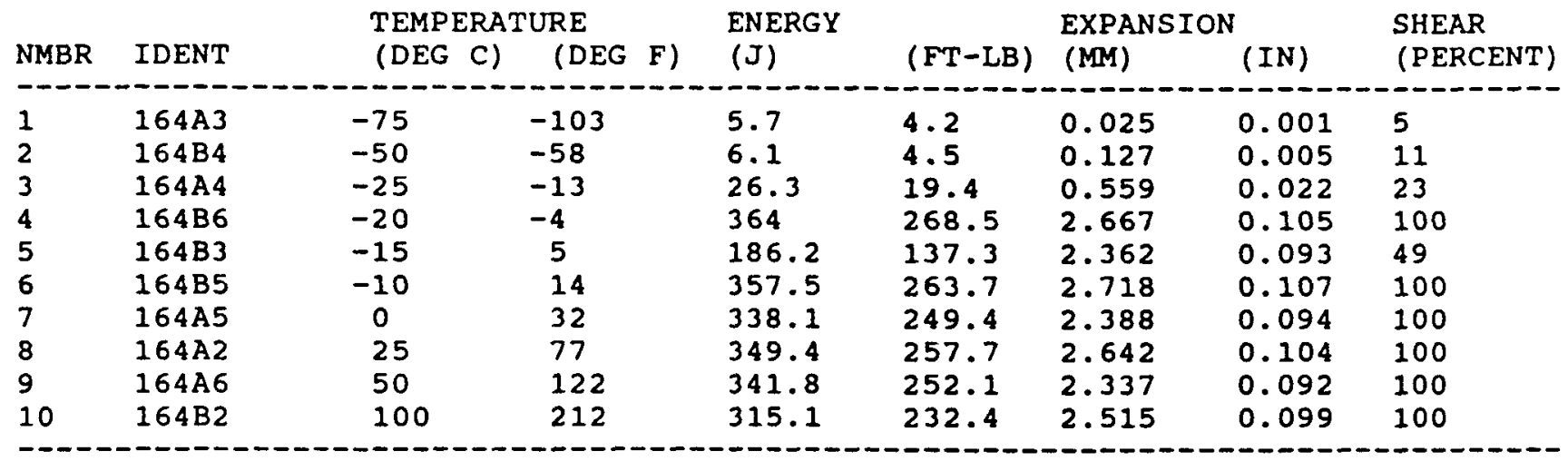


Table C2. Charpy impact data for weld 2, high-carbon SMA

SOURCE: ANALYSIS SET

ANALYSIS SETS

$$
\text { 2_AW 2_10_1150 2_5_1150 }
$$

SET NAME: 2 AW

REMARK: NON $\bar{E}$

\begin{tabular}{lcccccccc} 
NMBR & \multicolumn{2}{c}{ TEMPERATURE } & \multicolumn{2}{c}{ ENERGY } & \multicolumn{2}{c}{ EXPANSION } & SHEAR \\
IDENT & (DEG C) & (DEG F) & (J) & (FT-LB) & (MM) & (IN) & (PERCENT) \\
\hline 1 & $200 A 4$ & -50 & -58 & 25.9 & 19.1 & 0.406 & 0.016 & 22 \\
2 & $200 B 4$ & -25 & -13 & 42 & 31 & 0.66 & 0.026 & 40 \\
3 & $200 A 3$ & 0 & 32 & 49.9 & 36.8 & 0.533 & 0.021 & 39 \\
4 & $200 B 3$ & 25 & 77 & 70.9 & 52.3 & 0.991 & 0.039 & 95 \\
5 & $200 A 2$ & 50 & 122 & 86.6 & 63.9 & 1.27 & 0.05 & 99 \\
6 & $200 B 2$ & 100 & 212 & 85.4 & 63 & 1.168 & 0.046 & 99
\end{tabular}

SET NAME: 2_10_1150

REMARK: NON $\bar{E}$

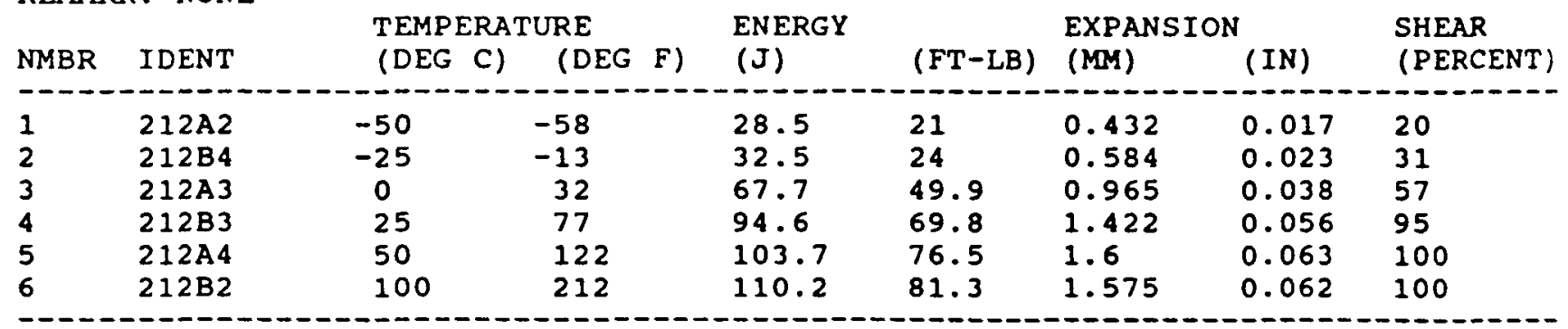

SET NAME: 2_5_1150

\begin{tabular}{|c|c|c|c|c|c|c|c|c|}
\hline NMBR & IDENT & $\begin{array}{l}\text { TEMPERA } \\
\text { (DEG C) }\end{array}$ & $\begin{array}{l}\text { TURE } \\
\text { (DEG F) }\end{array}$ & $\begin{array}{l}\text { ENERGY } \\
\text { (J) }\end{array}$ & $(F T-L B)$ & $\begin{array}{l}\text { EXPANSION } \\
\text { (MM) }\end{array}$ & (IN) & $\begin{array}{l}\text { SHEAR } \\
\text { (PERCENT) }\end{array}$ \\
\hline $\begin{array}{l}1 \\
2 \\
3 \\
4 \\
5 \\
6\end{array}$ & $\begin{array}{l}211 \mathrm{~B} 4 \\
211 \mathrm{~A} 4 \\
211 \mathrm{~A} 3 \\
211 \mathrm{~B} 3 \\
211 \mathrm{~A} 2 \\
211 \mathrm{~B} 2\end{array}$ & $\begin{array}{l}-75 \\
-50 \\
0 \\
25 \\
50 \\
100\end{array}$ & $\begin{array}{c}-103 \\
-58 \\
32 \\
77 \\
122 \\
212\end{array}$ & $\begin{array}{l}18.8 \\
25.1 \\
59.8 \\
77.3 \\
103.9 \\
109.8\end{array}$ & $\begin{array}{l}13.9 \\
18.5 \\
44.1 \\
57 \\
76.6 \\
81\end{array}$ & $\begin{array}{l}0.229 \\
0.483 \\
1.016 \\
1.219 \\
1.626 \\
1.727\end{array}$ & $\begin{array}{l}0.009 \\
0.019 \\
0.04 \\
0.048 \\
0.064 \\
0.068\end{array}$ & $\begin{array}{l}8 \\
20 \\
67 \\
89 \\
99 \\
100\end{array}$ \\
\hline
\end{tabular}


Table C2. Continued

SOURCE: ANALYSIS SET

ANALYSIS SETS

$$
2^{2} 20 \_1150 \text { 2_40_1150 2_5_1250 }
$$

SET NAME: $2 \quad 20 \quad 1150$

REMARK: NON $\bar{E}-$

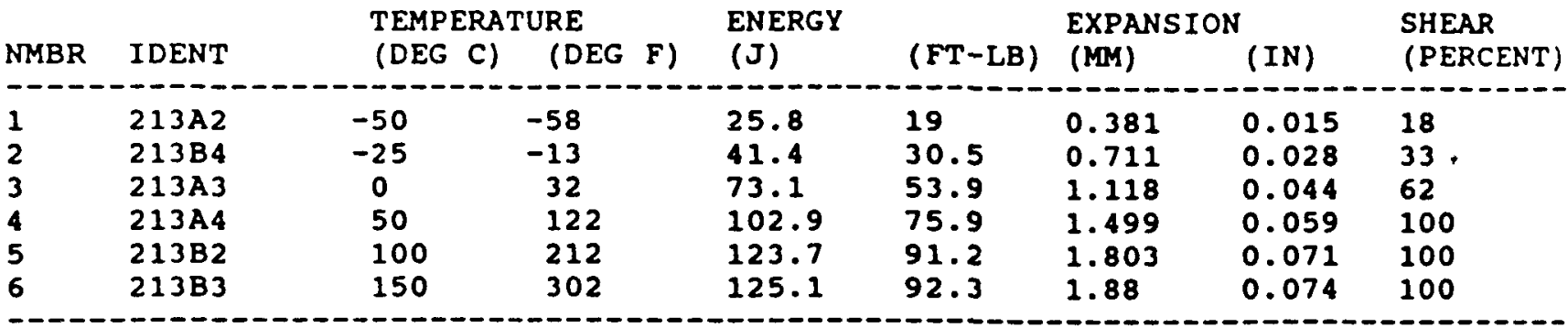

SET NAME: 2 20_1150

REMARK: NON $\bar{E}$

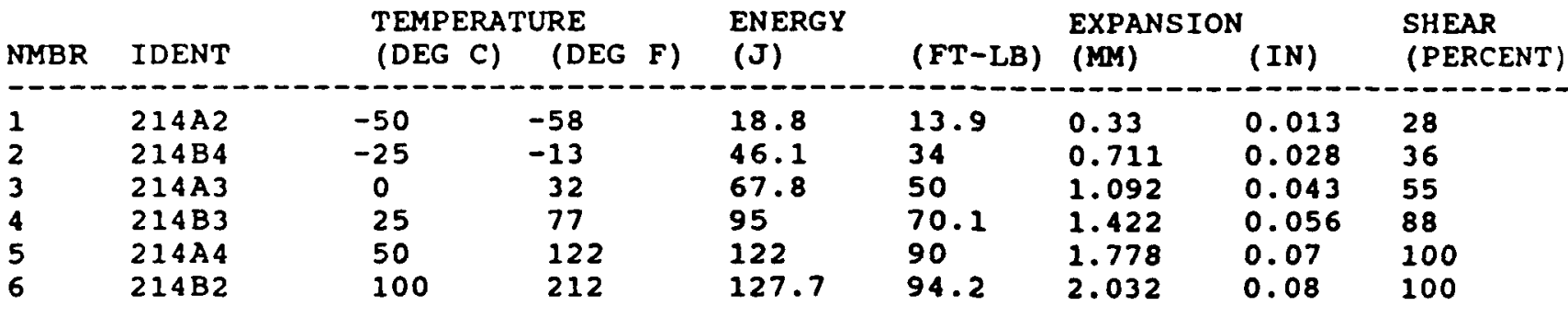

SET NAME: 2 5_1250

REMARK: NONE

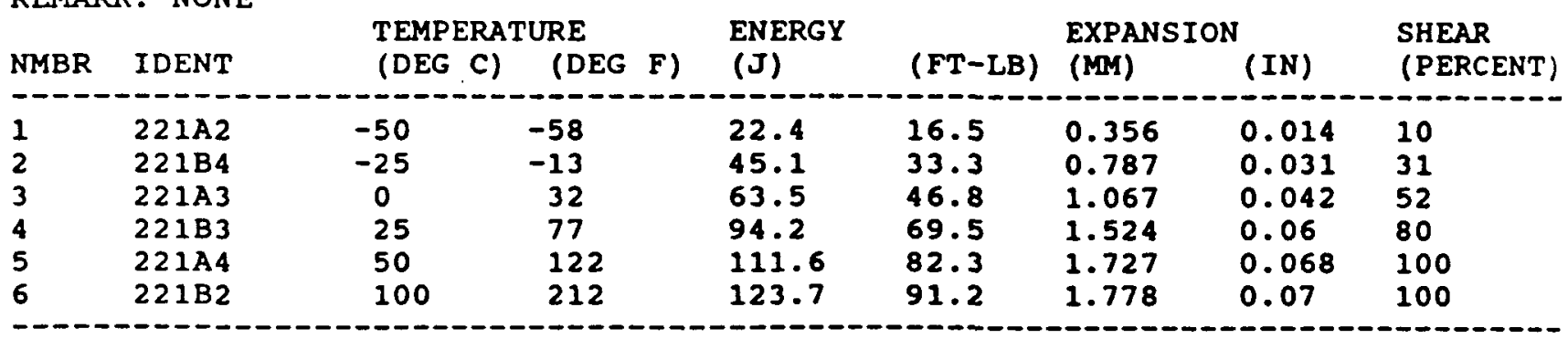


Table C2. Continued

SOURCE: ANALYSIS SET

ANALYSIS SETS

$$
\text { 2_10_1250 2_40_1250 2_20_1250 }
$$

SET NAME: 2_10_1250

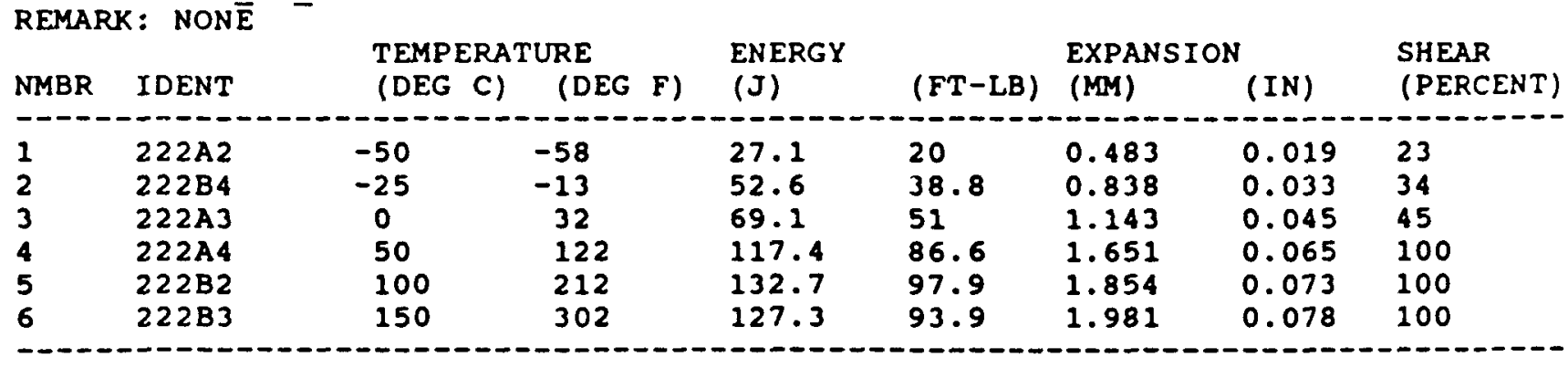

SET NAME: 2 40_1250

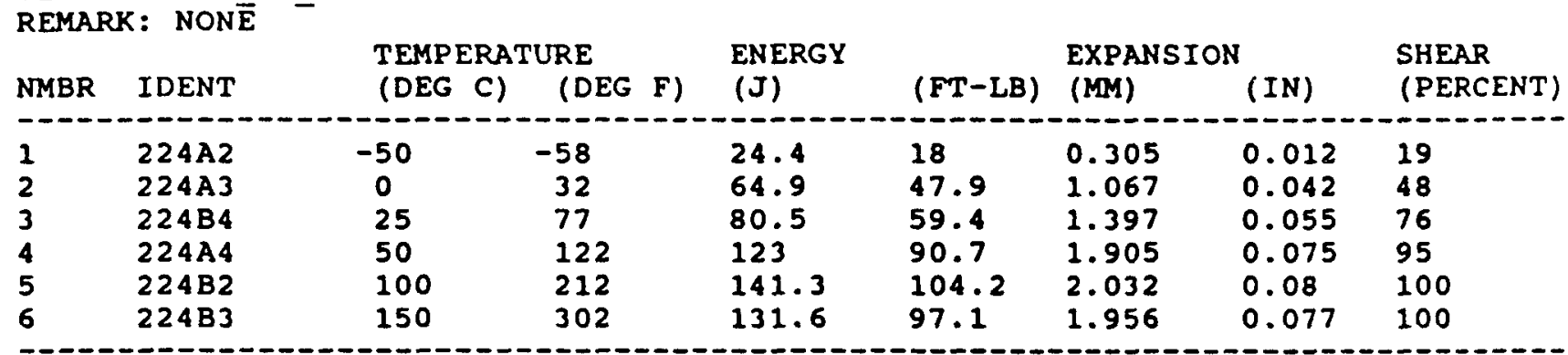

SET NAME: $2 \quad 20 \quad 1250$

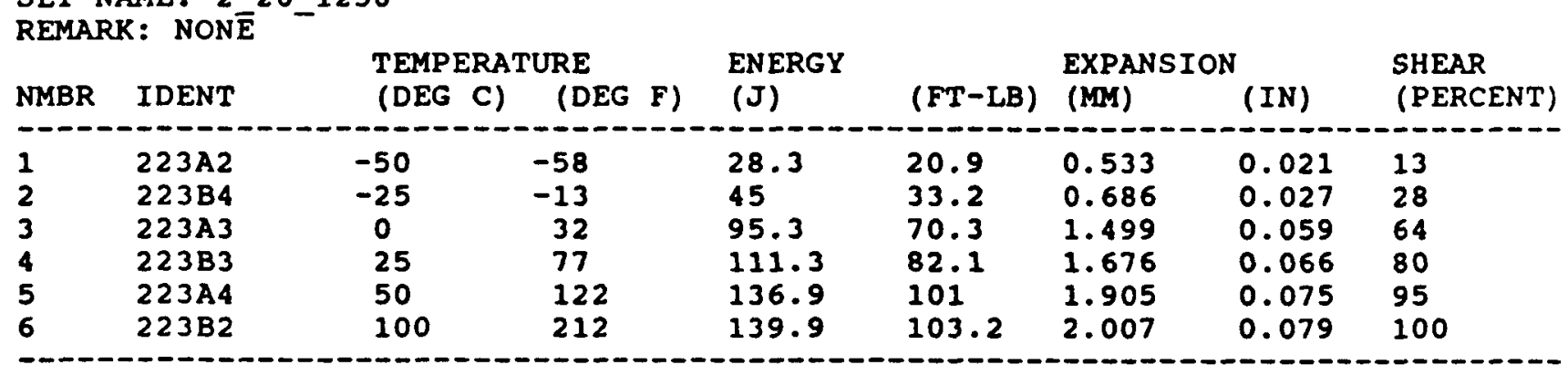


Table C2. Continued

SOURCE: ANALYSIS SET

ANALYSIS SETS

$$
\text { 2_5_1350 2_10_1350 2_20_1350 }
$$

SET NAME: 2 5_1350

REMARK: NON $\bar{E}$

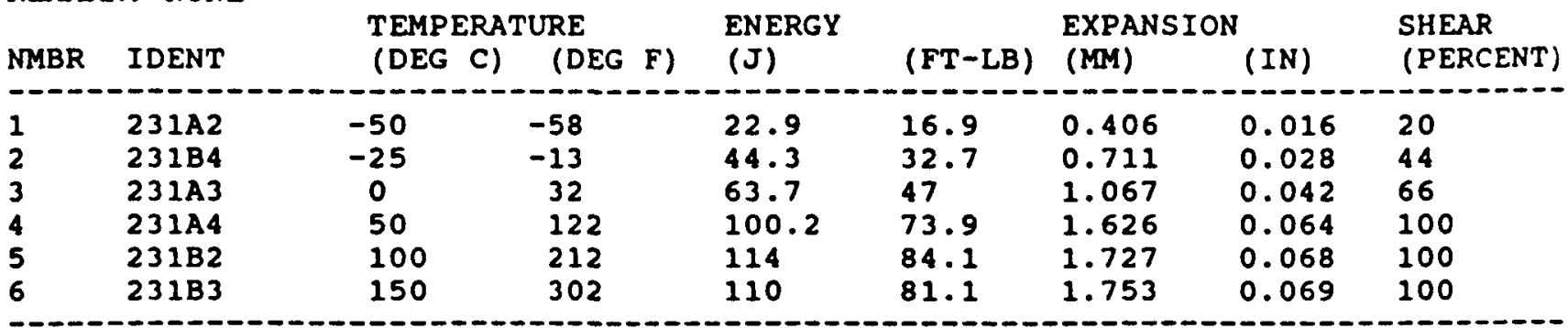

SET NAME: 2 10_1350

REMARK: NON $\bar{E}$

\begin{tabular}{|c|c|c|c|c|c|c|c|c|}
\hline NMBR & IDENT & $\begin{array}{l}\text { TEMPERA } \\
\text { (DEG C) }\end{array}$ & $\begin{array}{l}\text { CURE } \\
\text { (DEG F) }\end{array}$ & $\begin{array}{l}\text { ENERGY } \\
\text { (J) }\end{array}$ & $(F T-L B)$ & $\begin{array}{l}\text { EXPAN } \\
\text { (MM) }\end{array}$ & (IN) & $\begin{array}{l}\text { SHEAR } \\
\text { (PERCENT) }\end{array}$ \\
\hline $\begin{array}{l}1 \\
2 \\
3 \\
4 \\
5\end{array}$ & $\begin{array}{l}232 \mathrm{A2} \\
232 \mathrm{~B} 4 \\
232 \mathrm{A3} \\
232 \mathrm{B3} \\
232 \mathrm{A4} \\
232 \mathrm{B2}\end{array}$ & $\begin{array}{l}-50 \\
-25 \\
0 \\
25 \\
50 \\
100\end{array}$ & $\begin{array}{l}-58 \\
-13 \\
32 \\
77 \\
122 \\
212\end{array}$ & $\begin{array}{l}28.6 \\
45.4 \\
75.1 \\
86.6 \\
115.5 \\
120.8\end{array}$ & $\begin{array}{l}21.1 \\
33.5 \\
55.4 \\
63.9 \\
85.2 \\
89.1\end{array}$ & $\begin{array}{l}0.381 \\
0.813 \\
1.143 \\
1.372 \\
1.727 \\
1.854\end{array}$ & $\begin{array}{l}0.015 \\
0.032 \\
0.045 \\
0.054 \\
0.068 \\
0.073\end{array}$ & $\begin{array}{l}26 \\
34 \\
60 \\
88 \\
99 \\
100\end{array}$ \\
\hline
\end{tabular}

SET NAME: $2 \quad 20 \quad 1350$

REMARK: NON $\bar{E}$

\begin{tabular}{lcccccccc} 
NMBR & IDENT & \multicolumn{2}{c}{ TEMPERATURE } & \multicolumn{2}{c}{ ENERGY } & \multicolumn{2}{c}{ EXPANSION } & $\begin{array}{l}\text { SHEAR } \\
\text { (DEG C) }\end{array}$ \\
\hline & (DEG F) & (J) & (FT-LB) & (MM) & (IN) & (PERCENT) \\
\hline 1 & $233 A 2$ & -50 & -58 & 27.3 & 20.1 & 0.559 & 0.022 & 35 \\
2 & $233 B 4$ & -25 & -13 & 36.9 & 27.2 & 0.635 & 0.025 & 42 \\
3 & $233 A 3$ & 0 & 32 & 75.9 & 56 & 1.245 & 0.049 & 59 \\
4 & $233 A 4$ & 50 & 122 & 86.9 & 64.1 & 1.397 & 0.055 & 99 \\
5 & $233 B 2$ & 100 & 212 & 107 & 78.9 & 1.803 & 0.071 & 100 \\
6 & $233 B 3$ & 150 & 302 & 98.3 & 72.5 & 1.6 & 0.063 & 100 \\
\hline
\end{tabular}


Table C2. Continued

SOURCE: ANALYSIS SET

ANALYSIS SETS

$$
\text { 2_5_1450 2_10_1450 2_20_1450 }
$$

SET NAME: 2 5 1450

REMARK: NON $\bar{E}$

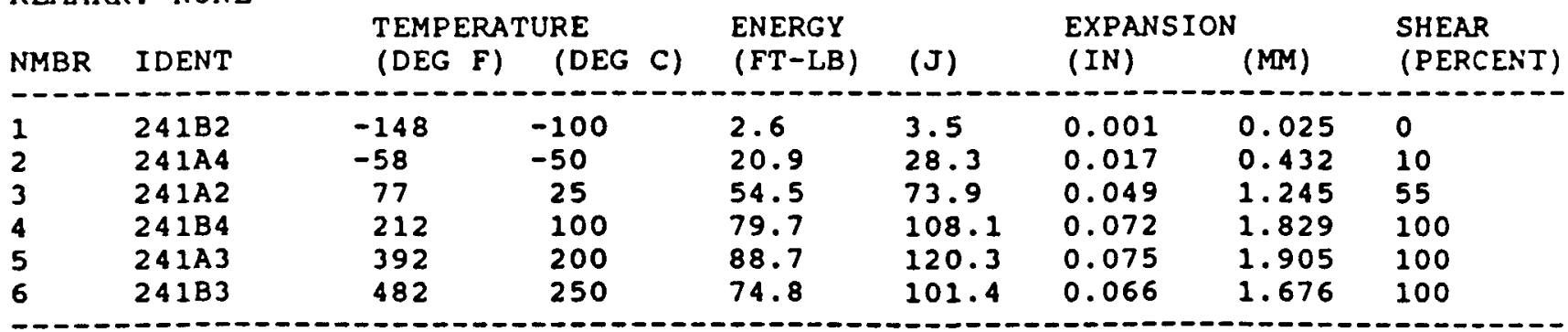

SET NAME: 2 10_1450

REMARK: NON $\bar{E}$

\begin{tabular}{lcccccccc} 
& \multicolumn{2}{c}{ TEMPERATURE } & \multicolumn{2}{c}{ ENERGY } & \multicolumn{2}{c}{ EXPANSION } & SHEAR \\
NMBR & IDENT & (DEG F) & (DEG C) & (FT-LB) & (J) & (IN) & (MM) & (PERCENT) \\
\hline 1 & $242 A 2$ & -148 & -100 & 3 & 4.1 & 0.005 & 0.127 & 0 \\
2 & $242 B 4$ & -58 & -50 & 9.3 & 12.6 & 0.012 & 0.305 & 5 \\
3 & $242 A 3$ & 32 & 0 & 51.8 & 70.2 & 0.045 & 1.143 & 45 \\
4 & $242 B 3$ & 122 & 50 & 65.5 & 88.8 & 0.061 & 1.549 & 95 \\
5 & $242 A 4$ & 212 & 100 & 90 & 122 & 0.074 & 1.88 & 100 \\
6 & $242 B 2$ & 482 & 250 & 84 & 113.9 & 0.075 & 1.905 & 100 \\
\hline
\end{tabular}

SET NAME: 2_20_1450

REMARK: NON $\bar{E}$

\begin{tabular}{|c|c|c|c|c|c|c|c|c|}
\hline NMBR & IDENT & $\begin{array}{l}\text { TEMPERA } \\
\text { (DEG F) }\end{array}$ & $\begin{array}{l}\text { TURE } \\
\text { (DEG C) }\end{array}$ & $\begin{array}{l}\text { ENERGY } \\
(\text { FT-LB) }\end{array}$ & (J) & $\begin{array}{l}\text { EXPAN } \\
\text { (IN) }\end{array}$ & (MM) & $\begin{array}{l}\text { SHEAR } \\
\text { (PERCENT) }\end{array}$ \\
\hline $\begin{array}{l}1 \\
2 \\
3 \\
4 \\
5\end{array}$ & $\begin{array}{l}243 A 4 \\
243 B 3 \\
243 B 4 \\
243 A 2 \\
243 A 3 \\
243 B 2\end{array}$ & $\begin{array}{c}-148 \\
-58 \\
32 \\
77 \\
212 \\
392\end{array}$ & $\begin{array}{l}-100 \\
-50 \\
0 \\
25 \\
100 \\
200\end{array}$ & $\begin{array}{l}2 \\
6 \\
28.8 \\
52 \\
90 \\
85.5\end{array}$ & $\begin{array}{l}2.7 \\
8.1 \\
39 \\
70.5 \\
122 \\
115.9\end{array}$ & $\begin{array}{l}0.005 \\
0.008 \\
0.03 \\
0.05 \\
0.081 \\
0.078\end{array}$ & $\begin{array}{l}0.127 \\
0.203 \\
0.762 \\
1.27 \\
2.057 \\
1.981\end{array}$ & $\begin{array}{l}0 \\
5 \\
30 \\
60 \\
100 \\
100\end{array}$ \\
\hline
\end{tabular}


Table C2. Continued

SOURCE: ANALYSIS SET

ANALYSIS SETS

$$
\text { 2_40_1350 2_40_1450 2_5_1650 }
$$

SET NAME: 2_40_1350

REMARK: NON $\bar{E}$

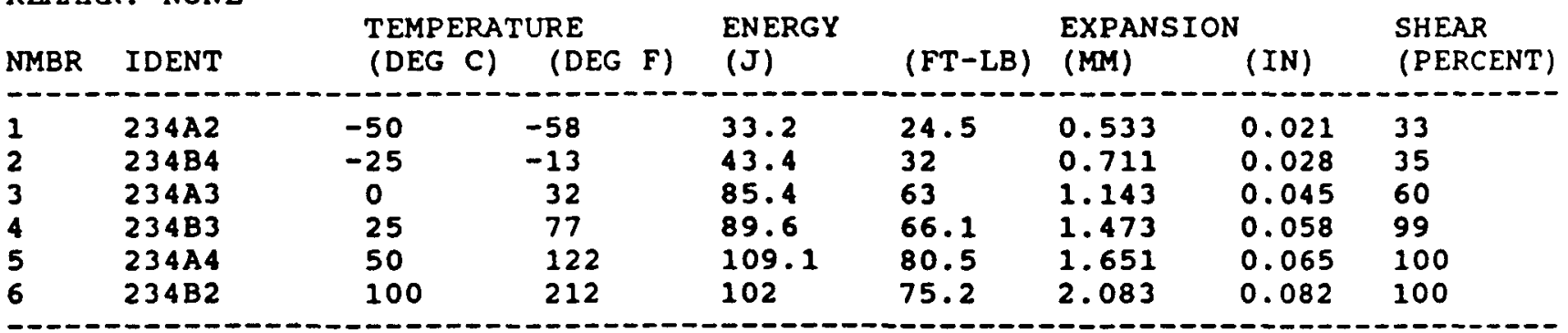

SET NAME: 2_40_1450

REMARR: NON $\overline{\mathrm{E}}$

\begin{tabular}{lcccccccc} 
NMBR & \multicolumn{2}{c}{ TEMPERATURE } & \multicolumn{2}{c}{ ENERGY } & \multicolumn{2}{c}{ EXPANSION } & SHEAR \\
(PERCENT)
\end{tabular}

SET NAME: 2 5 1650

REMARK: NON $\bar{E}$

\begin{tabular}{lcccccccc} 
& & \multicolumn{2}{c}{ TEMPERATURE } & \multicolumn{2}{c}{ ENERGY } & \multicolumn{2}{c}{ EXPANSION } & $\begin{array}{l}\text { SHEAR } \\
\text { NMBR }\end{array}$ \\
IDENT & (DEG C) & (DEG F) & (J) & (FT-LB) & (MM) & (IN) & (PERCENT) \\
\hline 1 & $261 B 2$ & -50 & -58 & 6.5 & 4.8 & 0.152 & 0.006 & 5 \\
2 & $261 A 4$ & 0 & 32 & 37.7 & 27.8 & 0.66 & 0.026 & 18 \\
3 & $261 A 2$ & 50 & 122 & 65.6 & 48.4 & 1.016 & 0.04 & 47 \\
4 & $261 B 4$ & 75 & 167 & 96 & 70.8 & 1.549 & 0.061 & 70 \\
5 & $261 A 3$ & 100 & 212 & 105.8 & 78 & 1.6 & 0.063 & 95 \\
6 & $261 B 3$ & 200 & 392 & 107.1 & 79 & 1.651 & 0.065 & 100 \\
\hline
\end{tabular}


SOURCE: ANALYSIS SET

ANALYSIS SETS

$$
\text { 2_40_1550 2_20_1550 2_40_1650 }
$$

SET NAME: $240 \_1550$

\begin{tabular}{|c|c|c|c|c|c|c|c|c|}
\hline MMBR & IDENT & $\begin{array}{l}\text { TEMPERA } \\
\text { (DEG C) }\end{array}$ & $\begin{array}{l}\text { CURE } \\
\text { (DEG F) }\end{array}$ & $\begin{array}{l}\text { ENERGY } \\
\text { (J) }\end{array}$ & $(F T-L B)$ & $\begin{array}{l}\text { EXPANS } \\
\text { (MM) }\end{array}$ & (IN) & $\begin{array}{l}\text { SHEAR } \\
\text { (PERCENT) }\end{array}$ \\
\hline $\begin{array}{l}1 \\
2 \\
3 \\
4 \\
5 \\
6\end{array}$ & $\begin{array}{l}254 \mathrm{A3} \\
254 \mathrm{B2} \\
254 \mathrm{A2} \\
254 \mathrm{B3} \\
254 \mathrm{A4} \\
254 \mathrm{~B} 4\end{array}$ & $\begin{array}{l}-50 \\
0 \\
25 \\
50 \\
100 \\
200\end{array}$ & $\begin{array}{c}-58 \\
32 \\
77 \\
122 \\
212 \\
392\end{array}$ & $\begin{array}{l}4.3 \\
11.3 \\
41.2 \\
68.3 \\
104.4 \\
99.1\end{array}$ & $\begin{array}{l}3.2 \\
8.3 \\
30.4 \\
50.4 \\
77 \\
73.1\end{array}$ & $\begin{array}{l}0.152 \\
0.279 \\
0.737 \\
1.118 \\
1.702 \\
1.778\end{array}$ & $\begin{array}{l}0.006 \\
0.011 \\
0.029 \\
0.044 \\
0.067 \\
0.07\end{array}$ & $\begin{array}{l}3 \\
13 \\
27 \\
50 \\
100 \\
100\end{array}$ \\
\hline
\end{tabular}

SET NAME: 2_20_1550

REMARK: NON $\bar{E}$

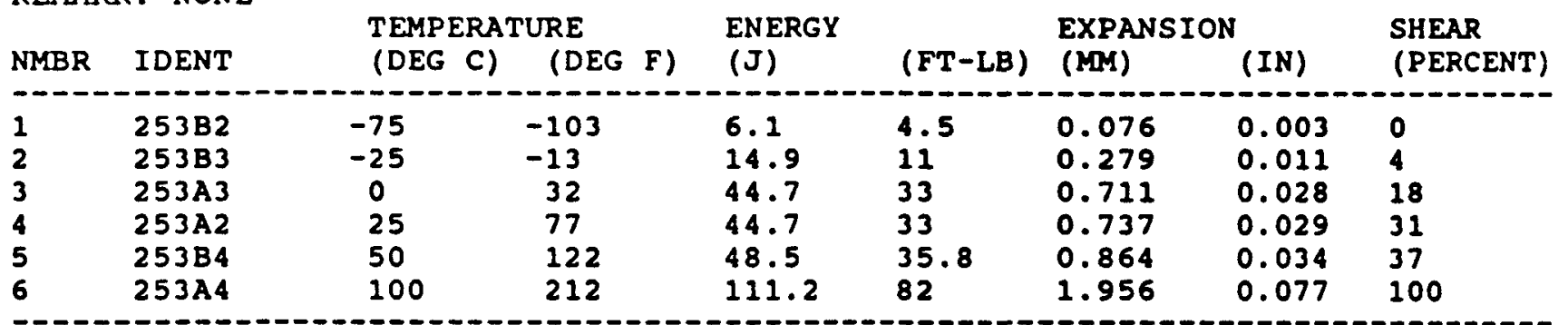

SET NAME: 2 40_1650

REMARK: NON $\bar{E}$

\begin{tabular}{|c|c|c|c|c|c|c|c|c|c|}
\hline NMBR & IDENT & $\begin{array}{l}\text { TEM } \\
\text { (DE }\end{array}$ & $\begin{array}{l}\text { TURE } \\
\text { (DEG }\end{array}$ & F) & $\begin{array}{l}\text { ENERGY } \\
\text { (J) }\end{array}$ & (FT-LB) & $\begin{array}{l}\text { EXPANSION } \\
\text { (MDM) }\end{array}$ & (IN) & $\begin{array}{l}\text { SHEAR } \\
\text { (PERCENT) }\end{array}$ \\
\hline $\begin{array}{l}1 \\
2 \\
3 \\
4 \\
5\end{array}$ & $\begin{array}{l}264 B 2 \\
264 A 4 \\
264 A 2 \\
264 A 3 \\
264 B 3 \\
264 B 4\end{array}$ & $\begin{array}{l}-50 \\
0 \\
50 \\
100 \\
150 \\
200\end{array}$ & $\begin{array}{l}-58 \\
32 \\
122 \\
212 \\
302 \\
392\end{array}$ & & $\begin{array}{l}2.6 \\
26.2 \\
57.5 \\
99.9 \\
112.5 \\
102.2\end{array}$ & $\begin{array}{l}1.9 \\
19.3 \\
42.4 \\
73.7 \\
83 \\
75.4\end{array}$ & $\begin{array}{l}0.076 \\
0.533 \\
0.787 \\
1.473 \\
1.778 \\
1.676\end{array}$ & $\begin{array}{l}0.003 \\
0.021 \\
0.031 \\
0.058 \\
0.07 \\
0.066\end{array}$ & $\begin{array}{l}\text { UNKWOWN } \\
9 \\
46 \\
85 \\
100 \\
100\end{array}$ \\
\hline
\end{tabular}


Table C2. Continued

SOURCE: ANALYSIS SET

ANALYSIS SETS

$$
\text { 2_10_1550 2_20_1650 2_5_1550 }
$$

SET NAME: 2_10_1550

REMARK: NON $\vec{E}-$

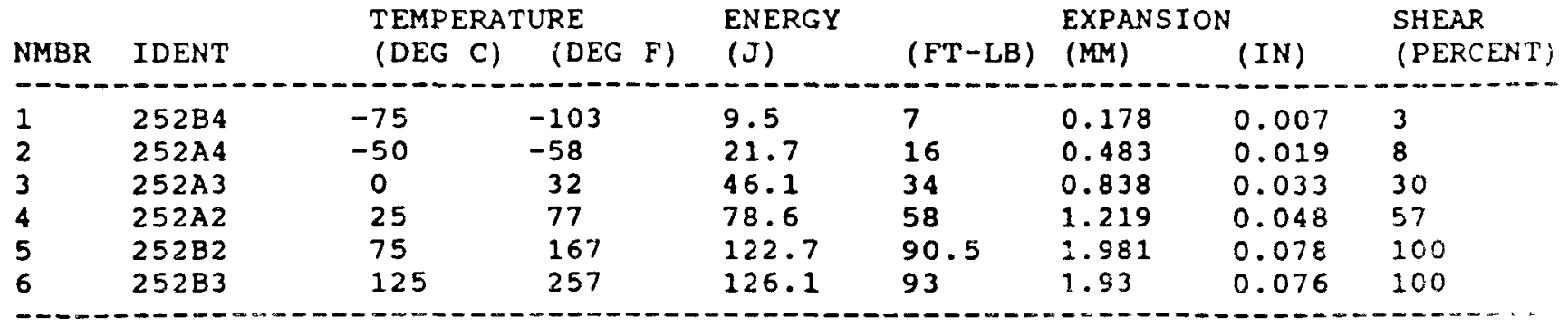

SET NAME: 2_20_1650

REMARK: NON $\bar{E}$

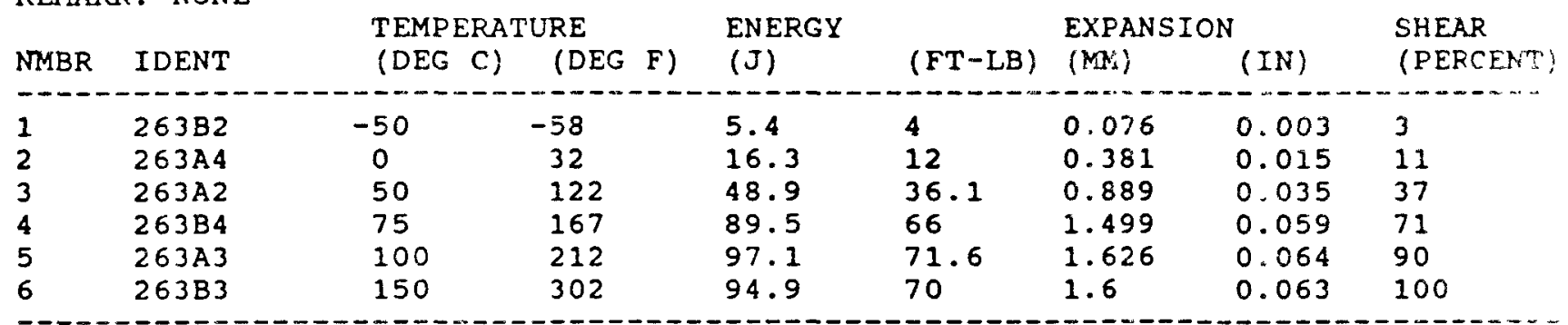

SET NAME: 2 5_1550

REMARK: NON $\vec{E}$

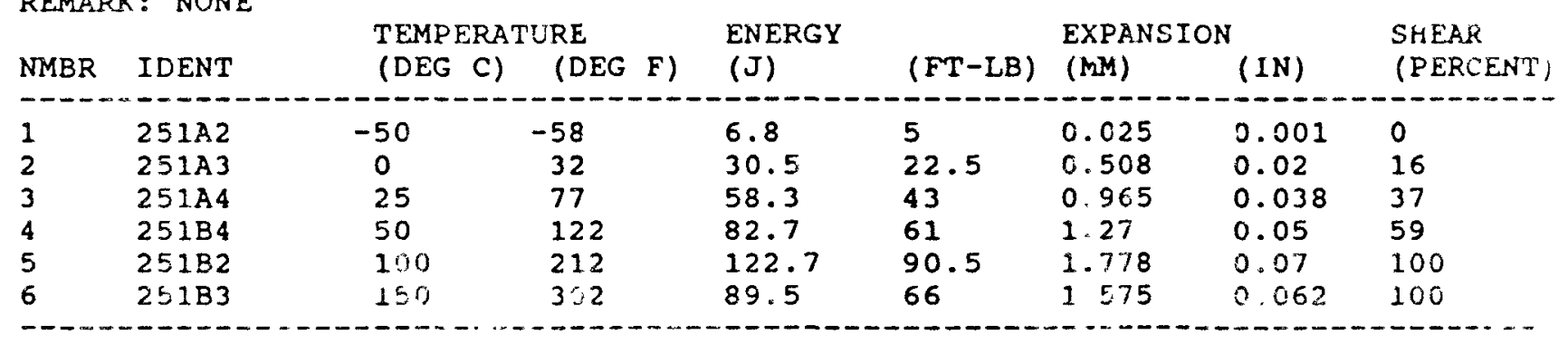


Table C2. Continued

SOURCE: ANALYSIS SET

ANALYSIS SET: 2_10_1650

SET NAME: 2 10_1650

REMARK : NON $\bar{E}$

TEMPERATURE

NMBR IDENT (DEG C)

ENERGY

(FT-LB) (MM)

EXPANSION

SHEAR

$1262 \mathrm{B2}$

$262 A 4$

$262 \mathrm{B3}$

$262 A 2$

$262 A 3$

$-75$

0

25

50

100 EG F)

(J)

10.4

14. 1

46.2

64.5

34.1

47.6

0.305

(PERCENT)

$262 \mathrm{~B} 4$

200

122

212

90.4

132.2

66.7

97.5

128.4

94.7

0.838

0.012

3

1.092

1.473

0.033

34

2.007

0.058

40

60

$0.08 \quad 100$

--n-- - - - - - - - - - - - - - - 
Table C3. Charpy impact data for welo 3 high carbon FCA

SOURCE: ANALYSIS SET

ANALYSIS SETS

$$
\text { 3_5_1150 3_10_1150 3_20_1150 }
$$

SET NAME: $3 \quad 5 \quad 1150$

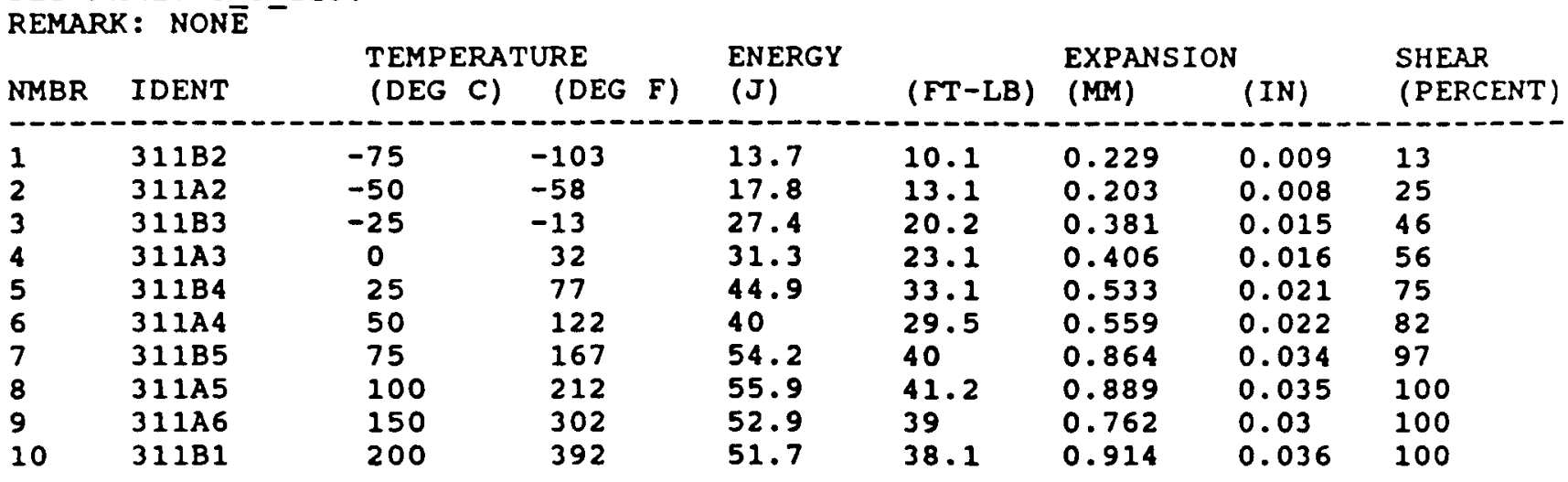

SET NAME: 3 10_1150

REMARK : NON $\bar{E}$

\begin{tabular}{lcccccccc} 
NMBR & IDENT & \multicolumn{2}{c}{$\begin{array}{c}\text { TEMPERATURE } \\
\text { (DEG C) }\end{array}$} & \multicolumn{2}{c}{$\begin{array}{c}\text { ENERGY } \\
\text { (DEG F) }\end{array}$} & EXPANSION & SHEAR \\
(JT-LB) & (MM) & (IN) & $\begin{array}{l}\text { SHERCENT) } \\
\text { (PER })\end{array}$ \\
\hline 1 & $312 B 3$ & -75 & -103 & 6.4 & 4.7 & 0.076 & 0.003 & 7 \\
2 & $312 C 2$ & -50 & -58 & 14.5 & 10.7 & 0.152 & 0.006 & 26 \\
3 & $312 B 4$ & -25 & -13 & 16.8 & 12.4 & 0.178 & 0.007 & 23 \\
4 & $312 C 3$ & 0 & 32 & 38 & 28 & 0.533 & 0.021 & 63 \\
5 & $312 B 5$ & 25 & 77 & 40.5 & 29.9 & 0.61 & 0.024 & 74 \\
6 & $312 C 4$ & 50 & 122 & 43.7 & 32.2 & 0.711 & 0.028 & 94 \\
7 & $312 B 2$ & 75 & 167 & 51 & 37.6 & 0.94 & 0.037 & 100 \\
8 & $312 C 5$ & 100 & 212 & 58.3 & 43 & 1.016 & 0.04 & 99 \\
9 & $312 C 6$ & 150 & 302 & 56.8 & 41.9 & 0.94 & 0.037 & 100 \\
10 & $312 B 1$ & 200 & 392 & 54.4 & 40.1 & 0.914 & 0.036 & 100
\end{tabular}

SET NAME: $3220 \_1150$

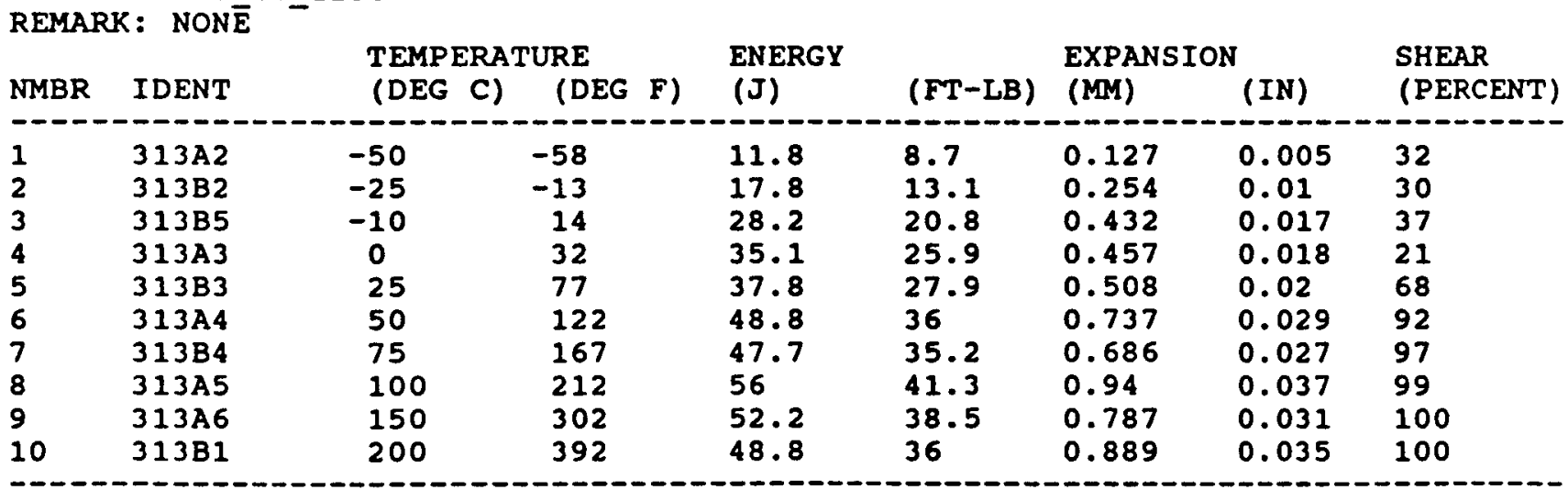


Table C3. Continued

SOURCE: ANALYSIS SET

ANALYSIS SETS

$$
\text { 3_40_1150 3_5_1250 3_10_1250 }
$$

SET NAME: 3_40_1150

REMARK: NONE

\begin{tabular}{|c|c|c|c|c|c|c|c|c|}
\hline NMBR & IDENT & $\begin{array}{l}\text { TEMPERAT } \\
\text { (DEG } \quad \text { C) }\end{array}$ & $\begin{array}{l}\text { URE } \\
\text { (DEG F) }\end{array}$ & $\begin{array}{l}\text { ENERGY } \\
\text { (J) }\end{array}$ & $(F T-L B)$ & $\begin{array}{l}\text { EXPANSION } \\
\text { (MM) }\end{array}$ & (IN) & $\begin{array}{l}\text { SHERR } \\
\text { (PERCENT) }\end{array}$ \\
\hline 1 & $314 \mathrm{A2}$ & -50 & -58 & 13.4 & 9.9 & 0.127 & 0.005 & 23 \\
\hline 2 & $314 \mathrm{~B} 4$ & -25 & -13 & 19.9 & 14.7 & 0.33 & 0.013 & 32 \\
\hline 3 & $314 A 3$ & 0 & 32 & 31.3 & 23.1 & 0.483 & 0.019 & 46 \\
\hline 4 & $314 \mathrm{B5}$ & 10 & 50 & 51.2 & 37.8 & 0.762 & 0.03 & 75 \\
\hline 5 & $314 \mathrm{B2}$ & 25 & 77 & 51.5 & 38 & 0.813 & 0.032 & 82 \\
\hline 6 & $314 A 4$ & 50 & 122 & 50.3 & 37.1 & 0.838 & 0.033 & 89 \\
\hline 7 & $314 \mathrm{~B} 3$ & 75 & 167 & 58.6 & 43.2 & 0.991 & 0.039 & 98 \\
\hline 8 & 314 A5 & 100 & 212 & 62.9 & 46.4 & 1.143 & 0.045 & 100 \\
\hline 9 & $314 A 6$ & 150 & 302 & 55.6 & 41 & 1.041 & 0.041 & 100 \\
\hline 10 & $314 \mathrm{BI}$ & 200 & 392 & 64.4 & 47.5 & 1.245 & 0.049 & 100 \\
\hline
\end{tabular}

SET NAME: 3_5_1250

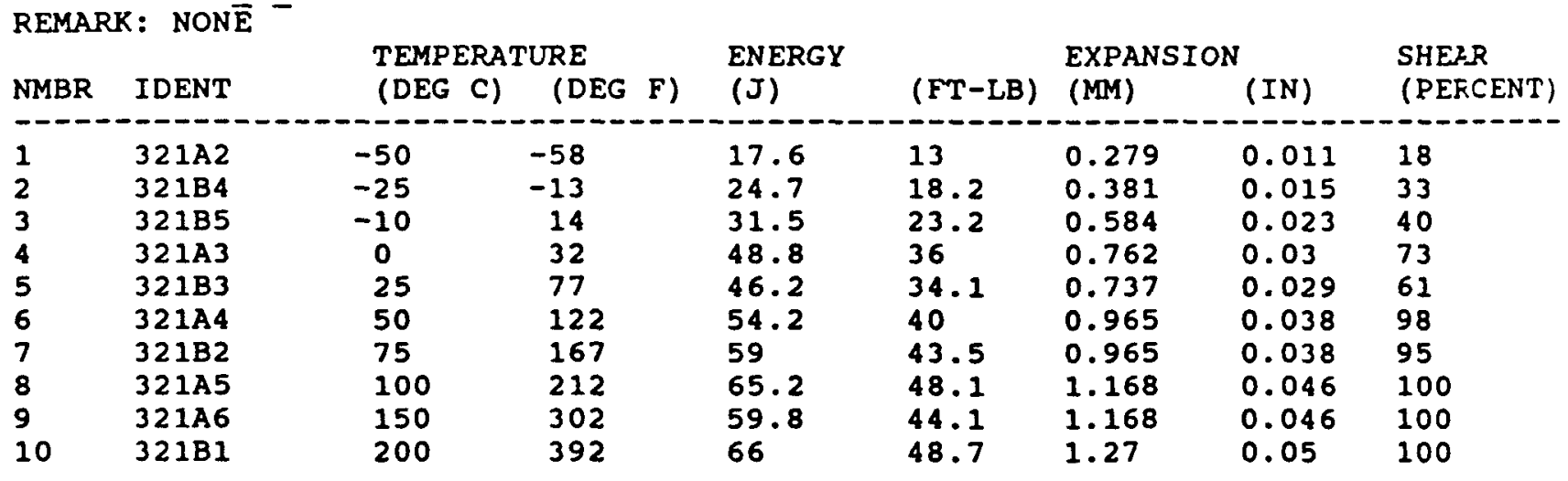

SET NAME: 3_10_1250

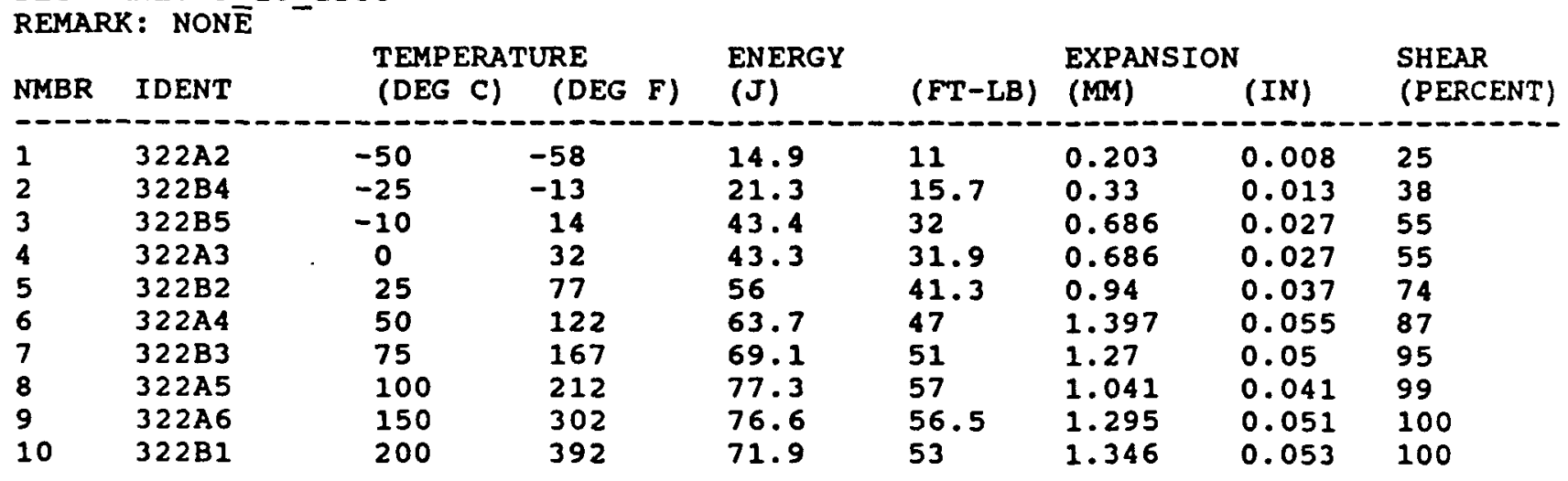


Table C3. Continued

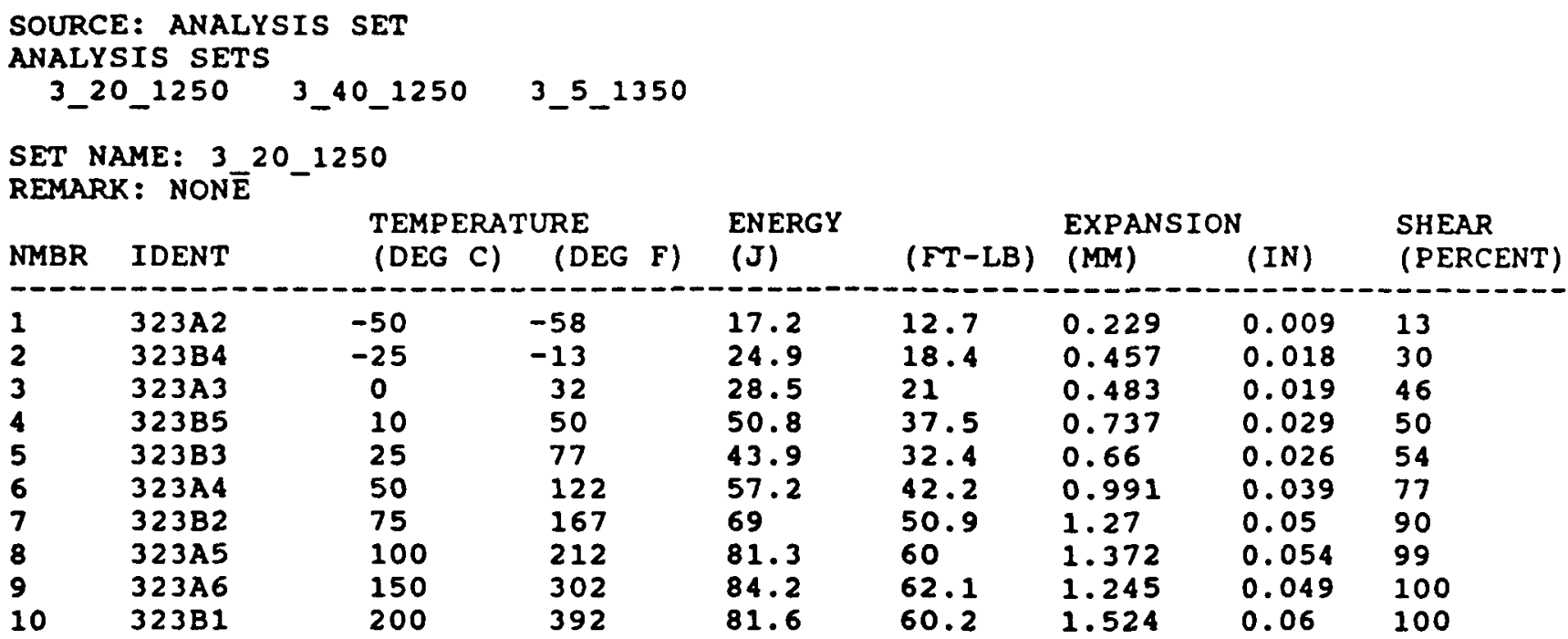

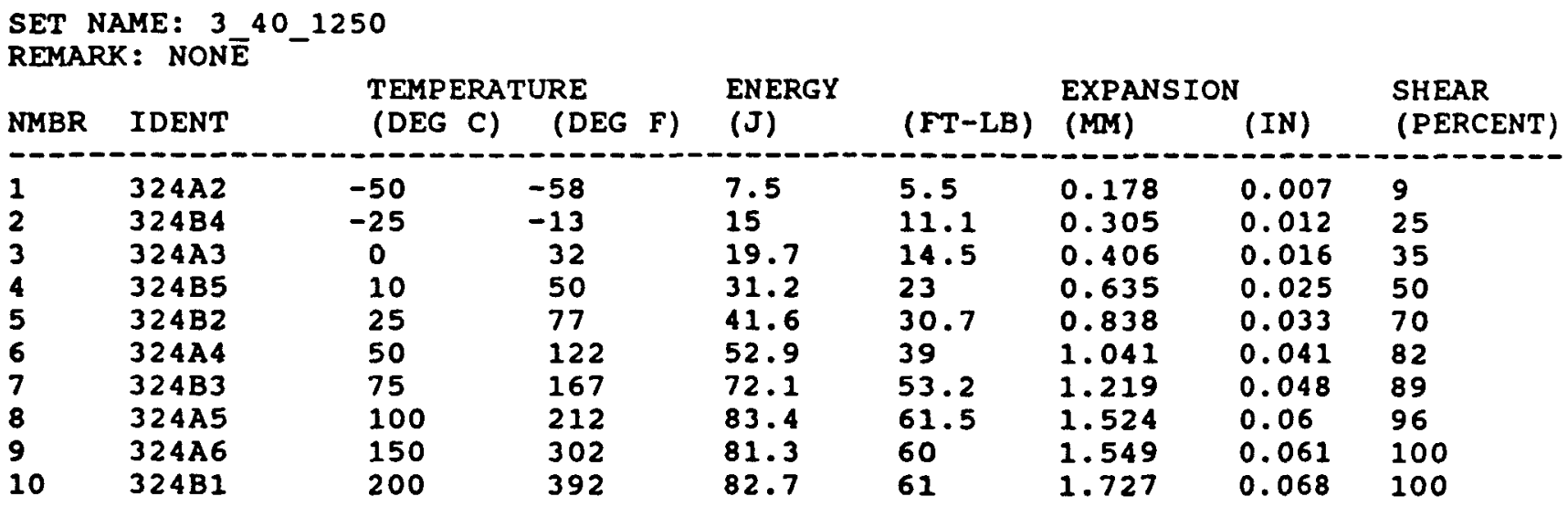

SET NAME: 3_5_1350

\begin{tabular}{|c|c|c|c|c|c|c|c|c|}
\hline NMBR & IDENT & $\begin{array}{l}\text { TEMPERA } \\
\text { (DEG C) }\end{array}$ & $\begin{array}{l}\text { rURE } \\
\text { (DEG F) }\end{array}$ & $\begin{array}{l}\text { ENERGY } \\
(\mathrm{J})\end{array}$ & (FT-IB) & $\begin{array}{l}\text { EXPANSION } \\
\text { (MM) }\end{array}$ & (IN) & $\begin{array}{l}\text { SHEAR } \\
\text { (PERCENT) }\end{array}$ \\
\hline $\begin{array}{l}1 \\
2 \\
3 \\
4 \\
5 \\
6 \\
7 \\
8 \\
9 \\
10\end{array}$ & $\begin{array}{l}331 \mathrm{~B} 4 \\
331 \mathrm{B2} \\
331 \mathrm{A2} \\
331 \mathrm{B3} \\
331 \mathrm{A3} \\
331 \mathrm{B5} \\
331 \mathrm{A4} \\
331 \mathrm{A5} \\
331 \mathrm{A6} \\
331 \mathrm{B1}\end{array}$ & $\begin{array}{l}-100 \\
-75 \\
-50 \\
-25 \\
0 \\
25 \\
50 \\
100 \\
150 \\
200\end{array}$ & $\begin{array}{l}-148 \\
-103 \\
-58 \\
-13 \\
32 \\
77 \\
122 \\
212 \\
302 \\
392\end{array}$ & $\begin{array}{l}11.8 \\
16.3 \\
30.5 \\
20.1 \\
23.2 \\
25.2 \\
24.4 \\
27.5 \\
26.4 \\
27.9\end{array}$ & $\begin{array}{l}8.7 \\
12 \\
22.5 \\
14.8 \\
17.1 \\
18.6 \\
18 \\
20.3 \\
19.5 \\
20.6\end{array}$ & $\begin{array}{l}0.051 \\
0.102 \\
0.178 \\
0.381 \\
0.254 \\
0.279 \\
0.203 \\
0.33 \\
0.33 \\
0.33\end{array}$ & $\begin{array}{l}0.002 \\
0.004 \\
0.007 \\
0.015 \\
0.01 \\
0.011 \\
0.008 \\
0.013 \\
0.013 \\
0.013\end{array}$ & $\begin{array}{l}3 \\
11 \\
13 \\
20 \\
73 \\
95 \\
98 \\
100 \\
100 \\
100\end{array}$ \\
\hline
\end{tabular}




\section{Table C3. Continued}

SOURCE: ANALYSIS SET

ANALYSIS SETS

$$
\text { 3_10_1350 3_20_1350 3_40_1350 }
$$

SET NAME: 3_10_1350

\begin{tabular}{|c|c|c|c|c|c|c|c|c|}
\hline NMBR & IDENT & $\begin{array}{l}\text { TEMF } \\
\text { (DEC }\end{array}$ & $\begin{array}{l}\text { TURE } \\
\text { (DEG }\end{array}$ & $\begin{array}{l}\text { ENERGY } \\
\text { (J) }\end{array}$ & $(F T-L B)$ & $\begin{array}{l}\text { EXPAN } \\
\text { (MM) }\end{array}$ & (IN) & $\begin{array}{l}\text { SHEAR } \\
\text { (PERCENT) }\end{array}$ \\
\hline $\begin{array}{l}1 \\
2 \\
3 \\
4 \\
5 \\
6 \\
7 \\
8 \\
9\end{array}$ & $\begin{array}{l}332 \mathrm{B3} \\
332 \mathrm{A2} \\
332 \mathrm{~B} 4 \\
332 \mathrm{A3} \\
332 \mathrm{B5} \\
332 \mathrm{~A} 4 \\
332 \mathrm{~A} 5 \\
332 \mathrm{~B} 2 \\
332 \mathrm{B1}\end{array}$ & $\begin{array}{l}-75 \\
-50 \\
-25 \\
0 \\
25 \\
50 \\
100 \\
150 \\
200\end{array}$ & $\begin{array}{l}-103 \\
-58 \\
-13 \\
32 \\
77 \\
122 \\
212 \\
302 \\
392\end{array}$ & $\begin{array}{l}7.9 \\
18.3 \\
20.9 \\
23.2 \\
28.2 \\
27.3 \\
29.7 \\
32.7 \\
33.2\end{array}$ & $\begin{array}{l}5.8 \\
13.5 \\
15.4 \\
17.1 \\
20.8 \\
20.1 \\
21.9 \\
24.1 \\
24.5\end{array}$ & $\begin{array}{l}0.102 \\
0.178 \\
0.203 \\
0.279 \\
0.33 \\
0.305 \\
0.381 \\
0.483 \\
0.483\end{array}$ & $\begin{array}{l}0.004 \\
0.007 \\
0.008 \\
0.011 \\
0.013 \\
0.012 \\
0.015 \\
0.019 \\
0.019\end{array}$ & $\begin{array}{l}10 \\
20 \\
90 \\
68 \\
54 \\
90 \\
99 \\
100 \\
100\end{array}$ \\
\hline
\end{tabular}

SET NAME: 3_20_1350

REMARK: NON $\bar{E}$

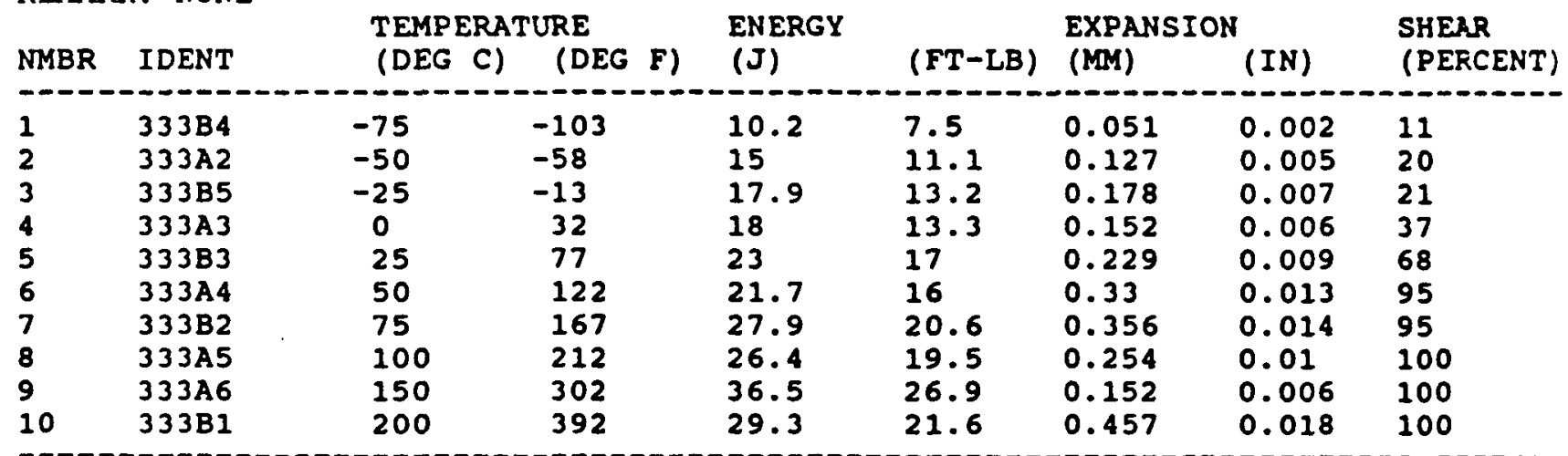

SET NAME: $3 \quad 40 \quad 1350$

REMARK: NON $\bar{E}$

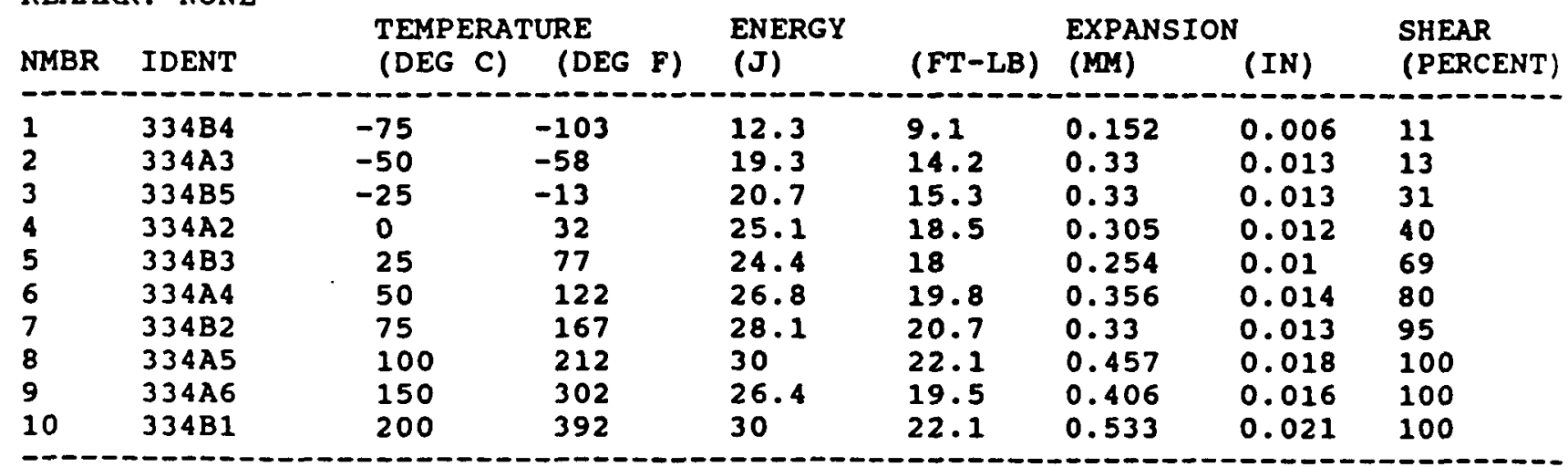


Table C3. Continued

SOURCE: ANALYSIS SET

ANALYSIS SETS

$$
\text { 3_5_1450 3_10_1450 3_20_1450 }
$$

SET NAME: 3_5_1450

REMARK: NON $\vec{E}$

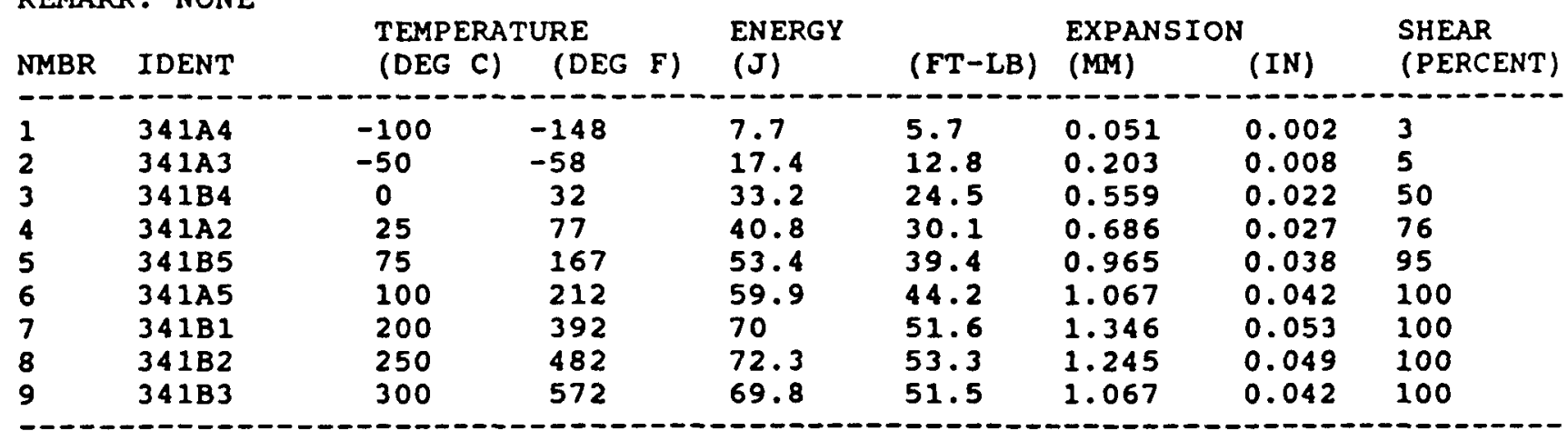

SET NAME: 3_10_1450

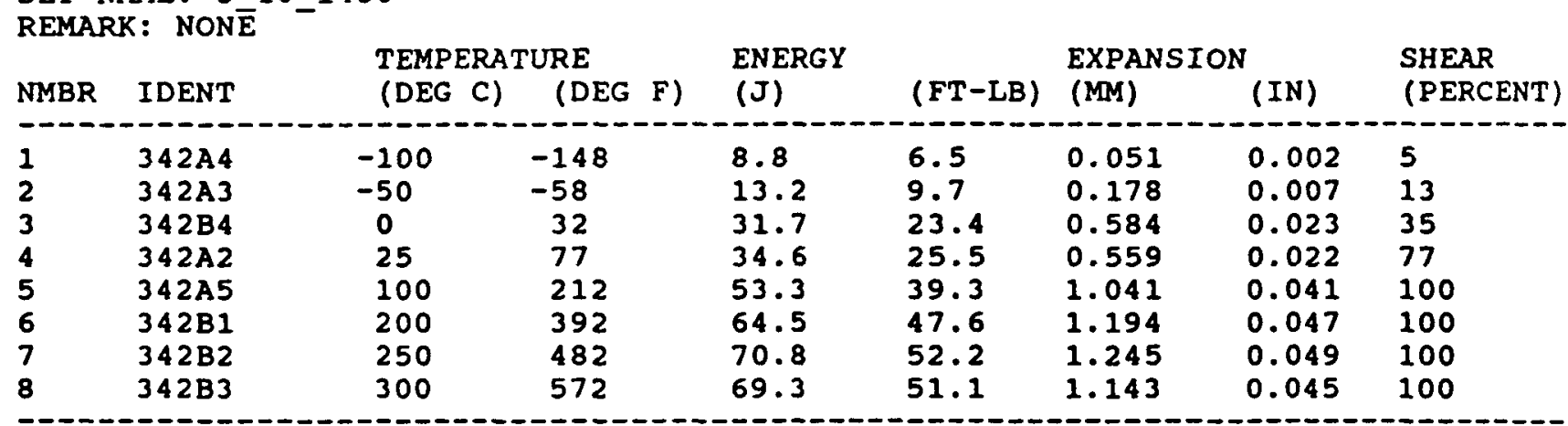

SET NAME: 3_20_1450

REMARK: NON $\bar{E}$

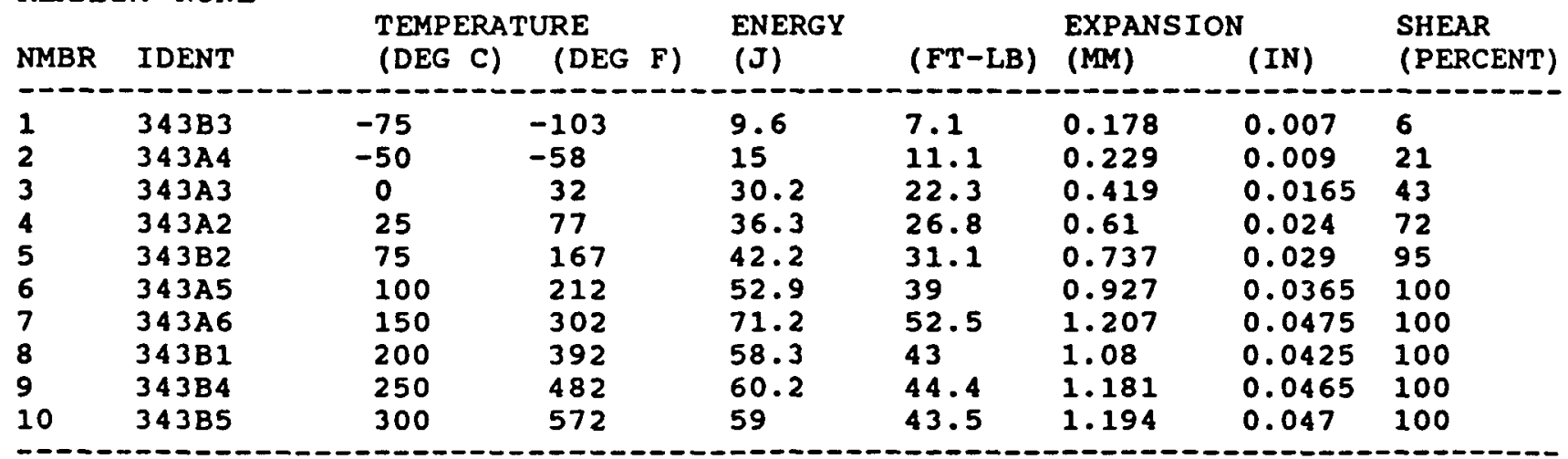


Table C3. Continued

SOURCE: ANALYSIS SET

ANALYSIS SETS

3_10_1650 3_40_1450 3_AW

SET NAME: $33_{10} 1650$

REMARK: NONE

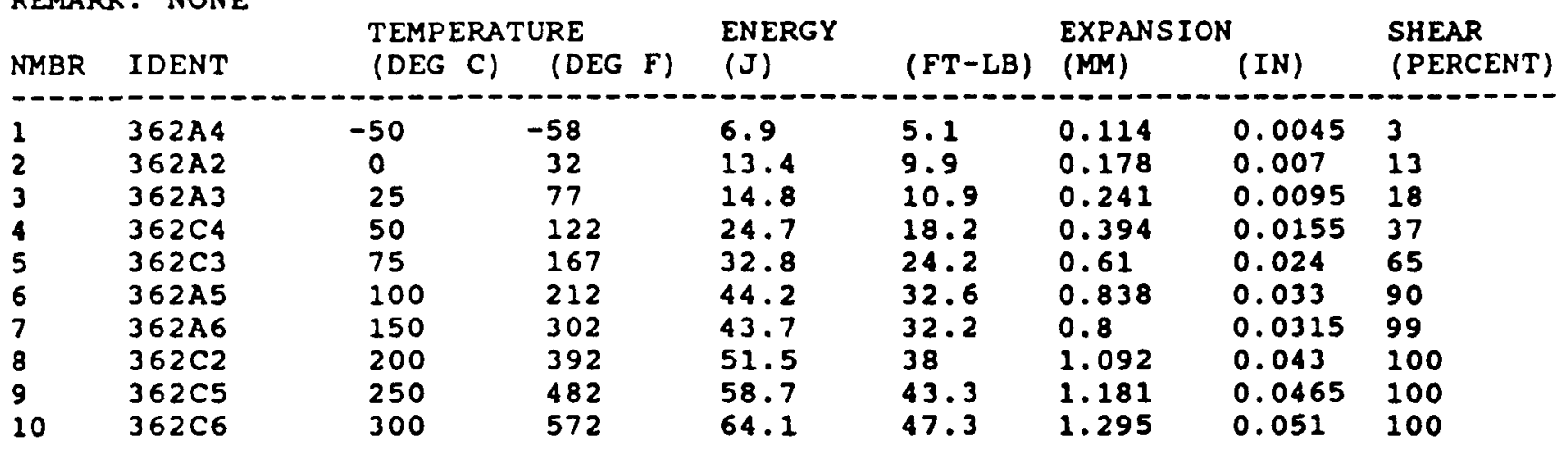

SET NAME: 3 40_1450

REMARK: NON $\vec{E}$

TEMPERATURE

ENERGY

EXPANSION

SHEAR

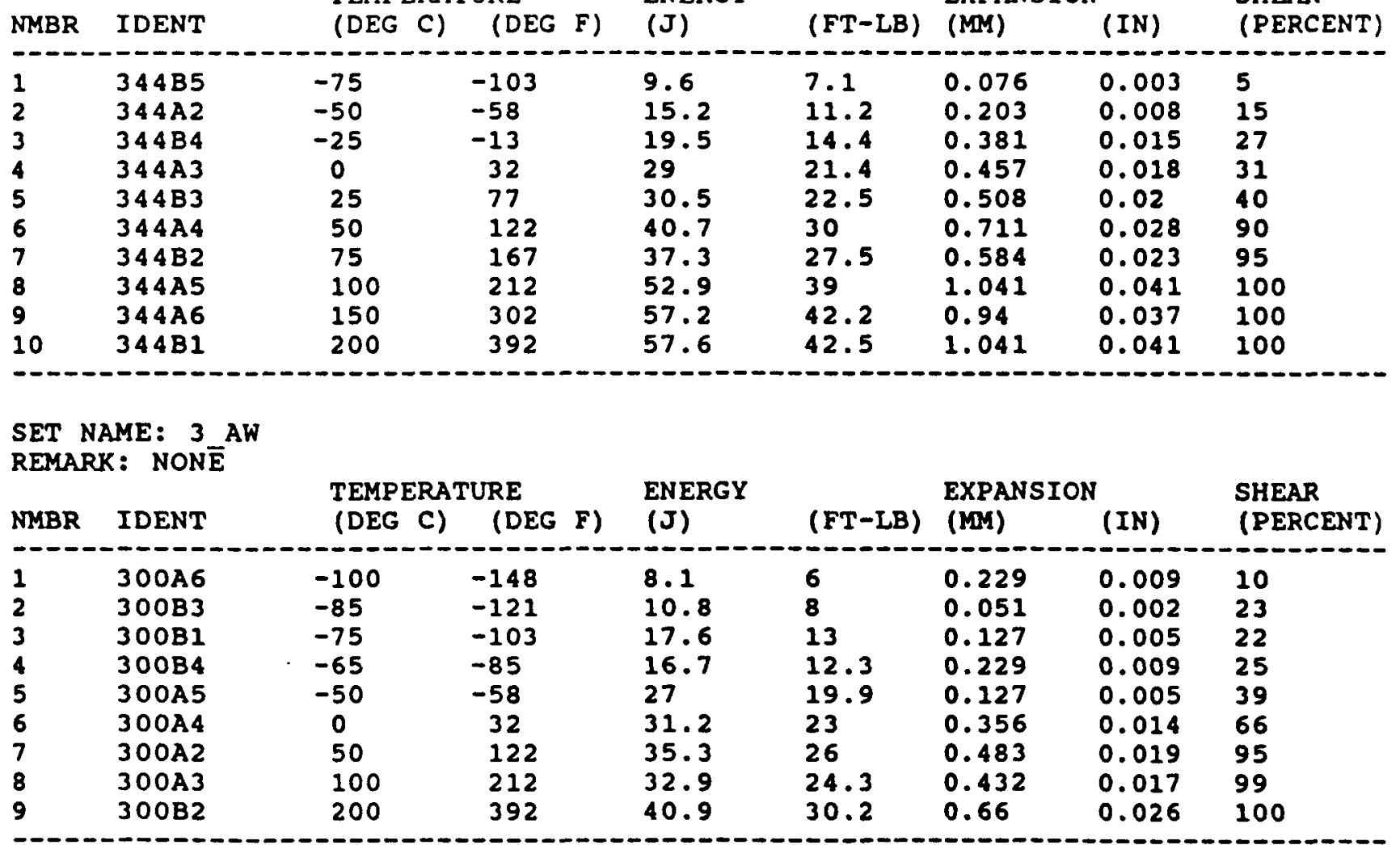


Table C3. Continued

SOURCE: ANALYSIS SET

ANALYSIS SETS

$$
\text { 3_5_1550 3_10_1550 3_20_1550 }
$$

SET NAME: 3 5 1550

REMARK: NONE

\begin{tabular}{lcccccccc} 
& \multicolumn{2}{c}{ TEMPERATURE } & \multicolumn{2}{c}{ ENERGY } & \multicolumn{2}{c}{ EXPANSION } & SHEAR \\
NMBR & IDENT & (DEG C) & (DEG F) & (J) & (FT-LB) & (MM) & $($ IN) & (PERCENT) \\
\hline 1 & $351 A 4$ & -50 & -58 & 7.2 & 5.3 & 0.102 & 0.004 & 5 \\
2 & $351 A 2$ & 0 & 32 & 13.3 & 9.8 & 0.229 & 0.009 & 15 \\
3 & $351 A 3$ & 25 & 77 & 16.9 & 12.5 & 0.241 & 0.0095 & 23 \\
4 & $351 B 2$ & 60 & 140 & 25.5 & 18.8 & 0.406 & 0.016 & 72 \\
5 & $351 B 4$ & 75 & 167 & 24.4 & 18 & 0.406 & 0.016 & 73 \\
6 & $351 A 5$ & 100 & 212 & 34.7 & 25.6 & 0.622 & 0.0245 & 90 \\
7 & $351 A 6$ & 150 & 302 & 45.8 & 33.8 & 0.889 & 0.035 & 100 \\
8 & $351 B 1$ & 200 & 392 & 36.2 & 26.7 & 0.686 & 0.027 & 100 \\
9 & $351 B 3$ & 250 & 482 & 34.8 & 25.7 & 0.635 & 0.025 & 100 \\
10 & $351 B 5$ & 300 & 572 & 41.5 & 30.6 & 0.965 & 0.038 & 100 \\
\hline
\end{tabular}

SET NAME: 3_10_1550

REMARK: NON $\bar{E}$

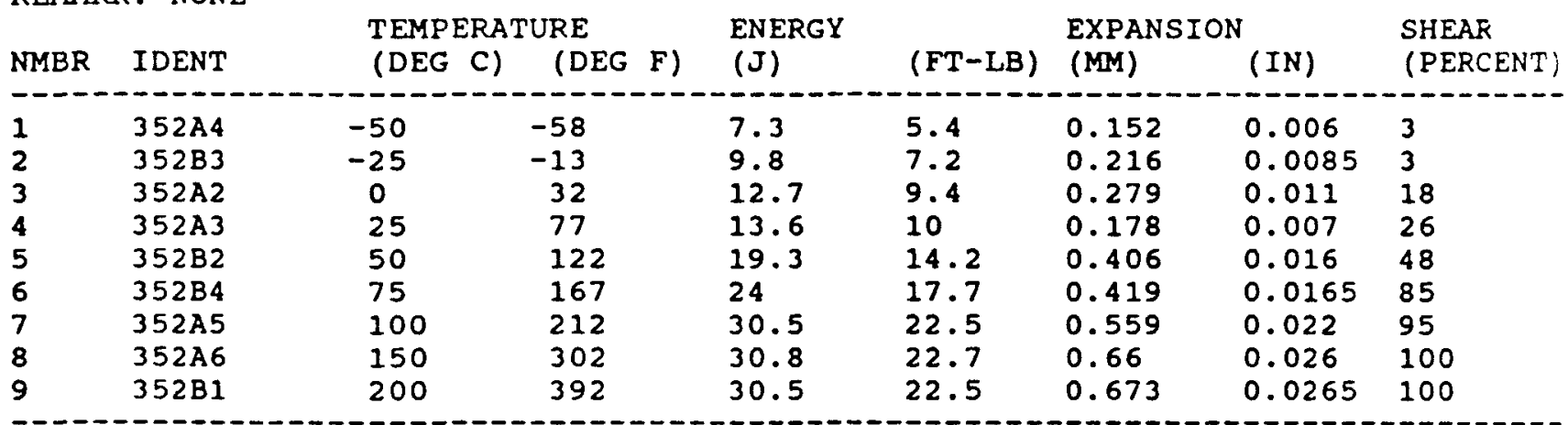

SET NAME: $320 \quad 1550$

REMARK: NONE

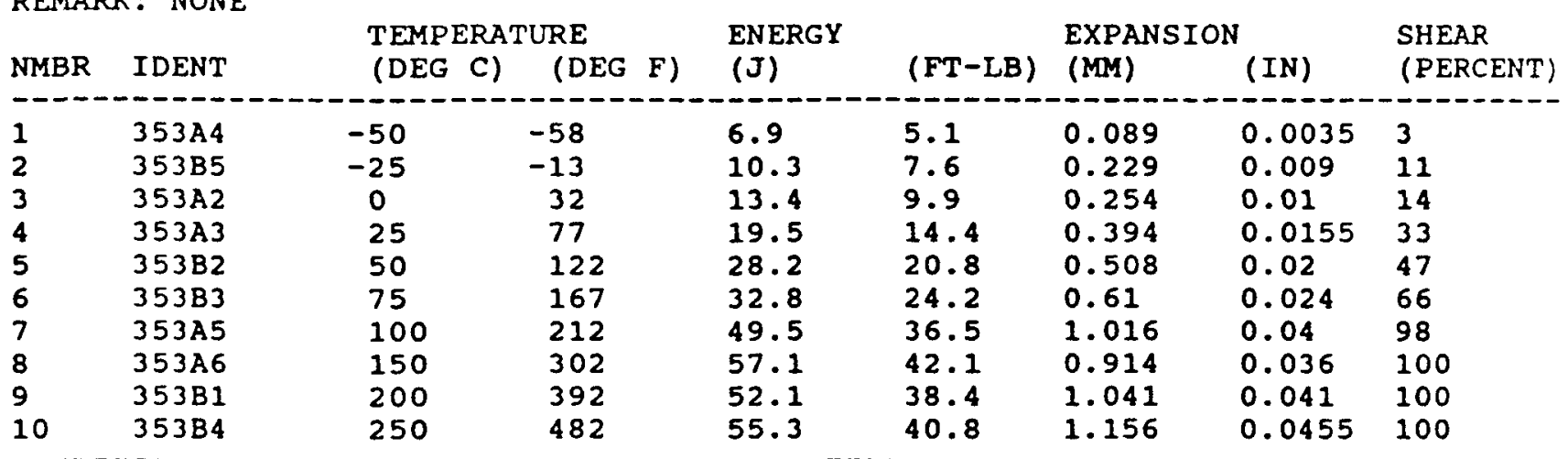


Table C3. Continued

SOURCE: ANALYSIS SET

ANALYSIS SETS

$$
\text { 3_20_1650 3_40_1550 3_40_1650 }
$$

SET NAME: 3_20_1650

REMARK: NON $\bar{E}$

\begin{tabular}{|c|c|c|c|c|c|c|c|c|c|}
\hline \multicolumn{2}{|c|}{ NMBR IDENT } & \multicolumn{2}{|c|}{ TEMPERATURE } & F) & $\begin{array}{l}\text { ENERGY } \\
\text { (J) }\end{array}$ & $(F T-L B)$ & \multicolumn{2}{|c|}{ EXPANSION } & $\begin{array}{l}\text { SHEAR } \\
\text { (PERCENT) }\end{array}$ \\
\hline 1 & $363 A 4$ & -50 & -58 & & 6.1 & 4.5 & 0.076 & 0.003 & 3 \\
\hline 2 & $363 A 2$ & 0 & 32 & & 11.4 & 8.4 & 0.216 & 0.0085 & 5 \\
\hline 3 & $363 A 3$ & 25 & 77 & & 18.3 & 13.5 & 0.318 & 0.0125 & 20 \\
\hline 4 & $363 \mathrm{B5}$ & 50 & 122 & & 32.9 & 24.3 & 0.622 & 0.0245 & 52 \\
\hline 5 & $363 \mathrm{B2}$ & 75 & 167 & & 33.2 & 24.5 & 0.61 & 0.024 & 56 \\
\hline 6 & $363 A 5$ & 100 & 212 & & 45.3 & 33.4 & 0.876 & 0.0345 & 85 \\
\hline 7 & $363 \mathrm{~B} 3$ & 150 & 302 & & 41.9 & 30.9 & 0.876 & 0.0345 & 99 \\
\hline 8 & $363 A 6$ & 200 & 392 & & 58.3 & 43 & 1.156 & 0.0455 & 100 \\
\hline 9 & $363 \mathrm{BI}$ & 250 & 482 & & 51.4 & 37.9 & 1.054 & 0.0415 & 100 \\
\hline 10 & $363 \mathrm{~B} 4$ & 300 & 572 & & 48.8 & 36 & 1.13 & 0.0445 & 100 \\
\hline
\end{tabular}

SET NAME: 3 40_1550

REMARK: NONE

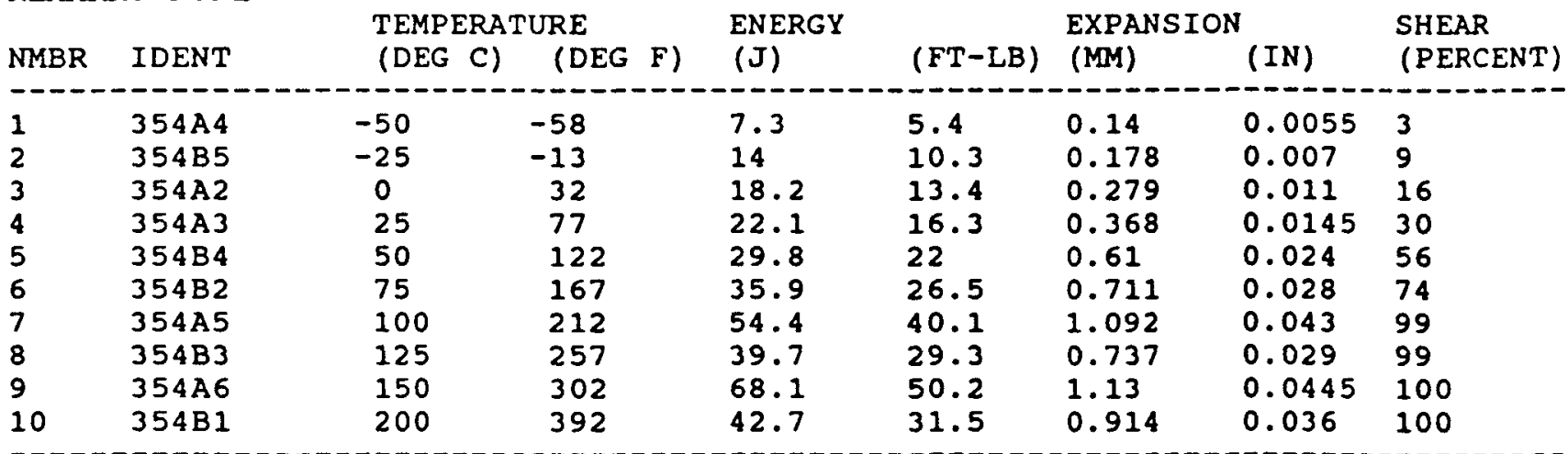

SET NAME: 3_40_1650

REMARK : NON $\bar{E}$

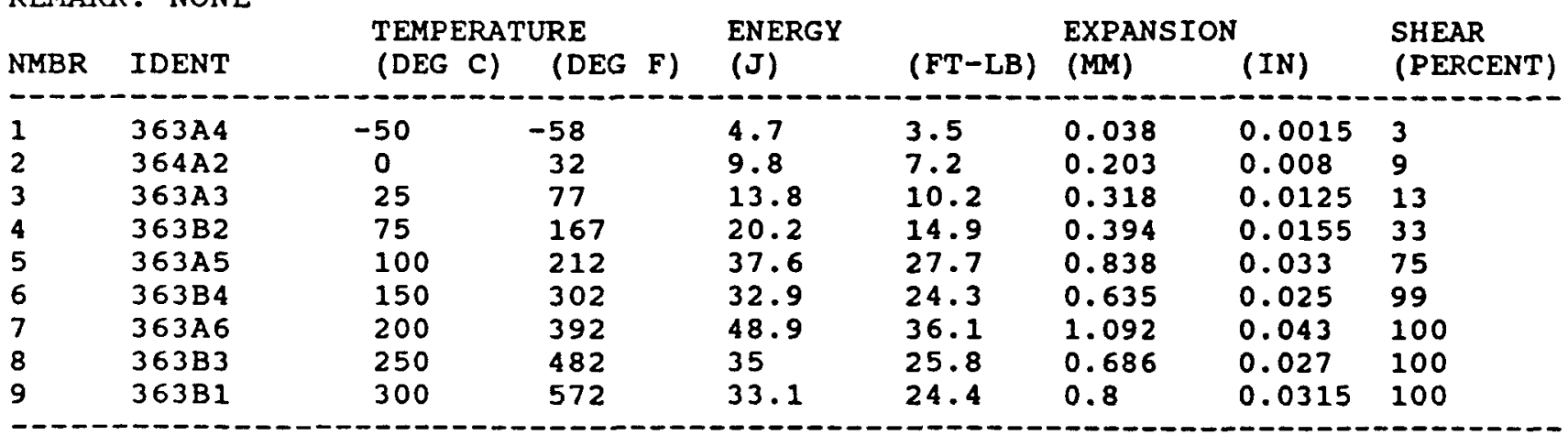


Table C3. Continued

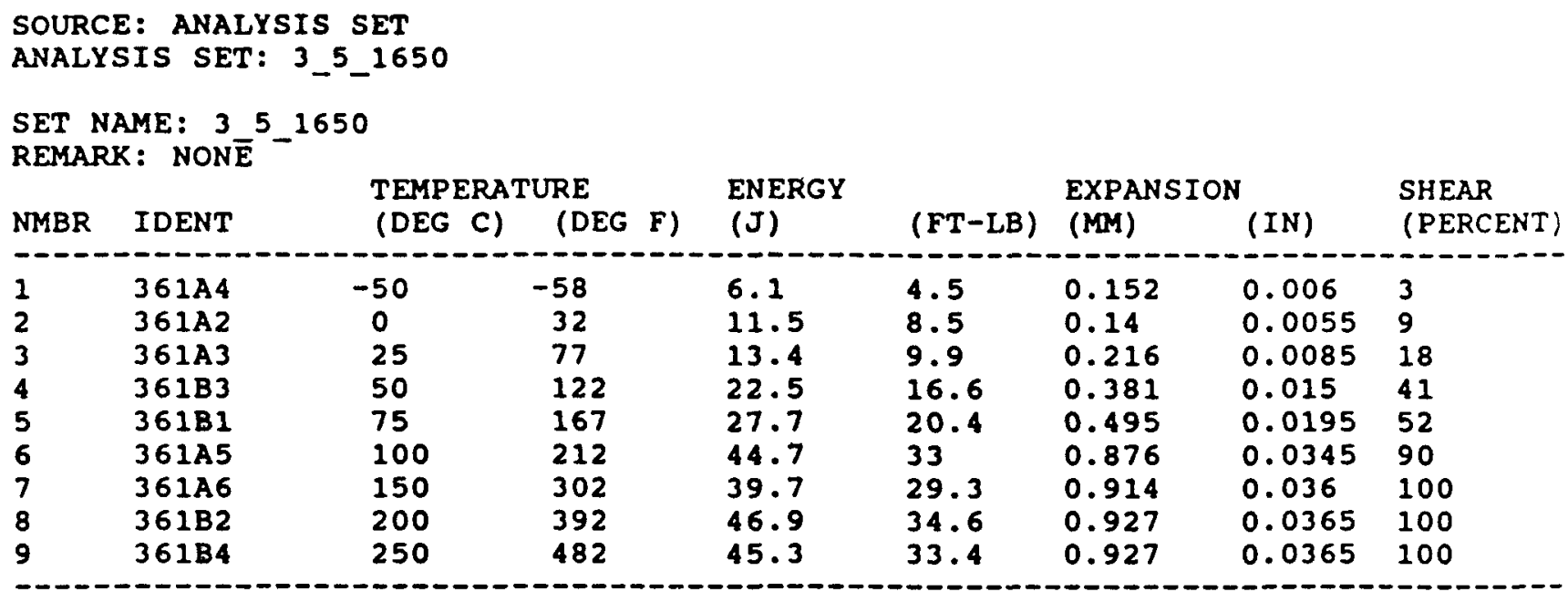


Table C4. Charpy impact data for weld 4, low-carbon FCA

SOURCE: ANALYSIS SET

ANALYSIS SETS

$$
\text { 4_AW 4_5_1150 4_10_1150 }
$$

SET NAME: 4 AW

REMARK: NON $\bar{E}$

\begin{tabular}{|c|c|c|c|c|c|c|c|c|}
\hline NMBR & IDENT & $\begin{array}{l}\text { TEMPERA } \\
\text { (DEG C) }\end{array}$ & $\begin{array}{l}\text { RURE } \\
\text { (DEG F) }\end{array}$ & $\begin{array}{l}\text { ENERGY } \\
\text { (J) }\end{array}$ & $(F T-L B)$ & $\begin{array}{l}\text { EXPANS } \\
\text { (MM) }\end{array}$ & (IN) & $\begin{array}{l}\text { SHEAR } \\
\text { (PERCENT) }\end{array}$ \\
\hline $\begin{array}{l}1 \\
2 \\
3 \\
4 \\
5 \\
6 \\
7\end{array}$ & $\begin{array}{l}400 A 4 \\
400 B 2 \\
400 A 3 \\
400 B 3 \\
400 A 2 \\
400 A 5 \\
400 A 6\end{array}$ & $\begin{array}{l}-50 \\
-25 \\
0 \\
25 \\
50 \\
100 \\
200\end{array}$ & $\begin{array}{l}-58 \\
-13 \\
32 \\
77 \\
122 \\
212 \\
392\end{array}$ & $\begin{array}{l}14.5 \\
35.4 \\
50.2 \\
44.7 \\
69.8 \\
71.7 \\
75.9\end{array}$ & $\begin{array}{l}10.7 \\
26.1 \\
37 \\
33 \\
51.5 \\
52.9 \\
56\end{array}$ & $\begin{array}{l}0.178 \\
0.279 \\
0.787 \\
0.635 \\
1.194 \\
1.27 \\
1.372\end{array}$ & $\begin{array}{l}0.007 \\
0.011 \\
0.031 \\
0.025 \\
0.047 \\
0.05 \\
0.054\end{array}$ & $\begin{array}{l}23 \\
48 \\
59 \\
74 \\
95 \\
99 \\
100\end{array}$ \\
\hline
\end{tabular}

SET NAME: 4 5 1150

REMARK: NON $\bar{E}$

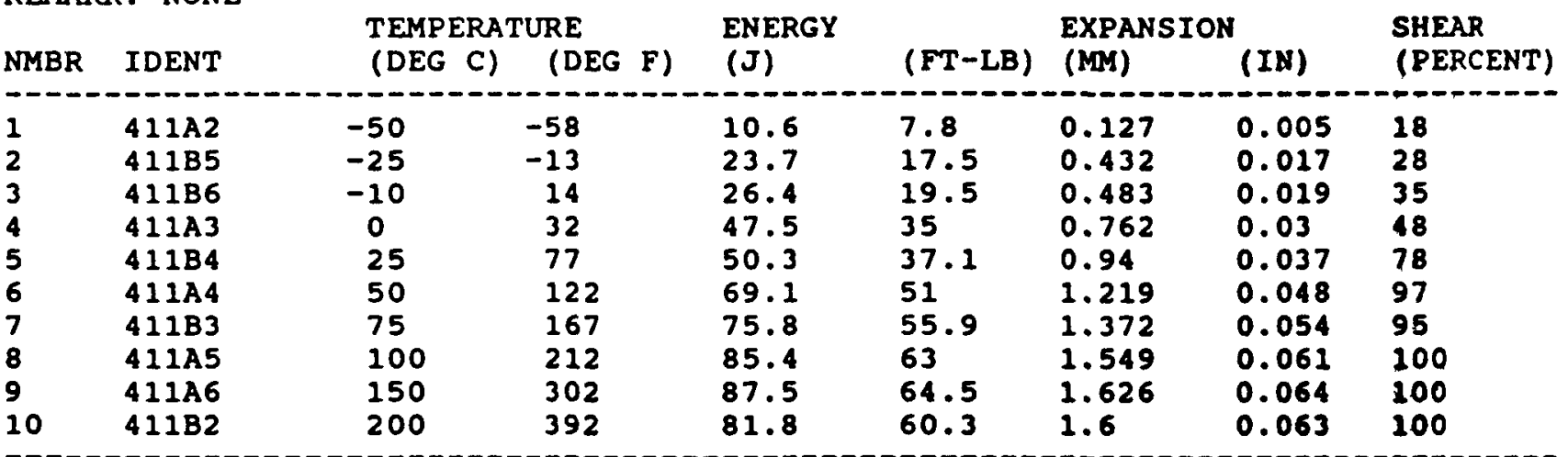

SET NAME: 4_10_1150

REMARK:
NONE




\section{Table C4. Continued}

SOURCE: ANALYSIS SET

ANALYSIS SETS

$$
\text { 4_20_1150 4_40_1150 4_5_1250 }
$$

SET NAME: $4 \quad 20 \quad 1150$

REMARK : NON $\bar{E}$

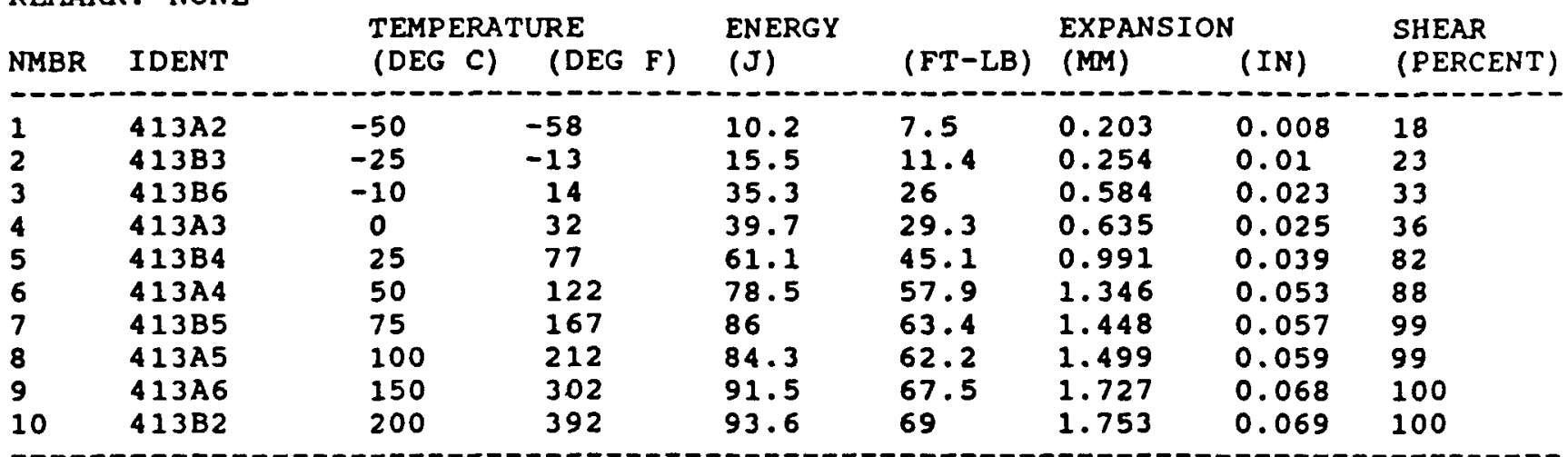

SET NAME: 4_40_1150

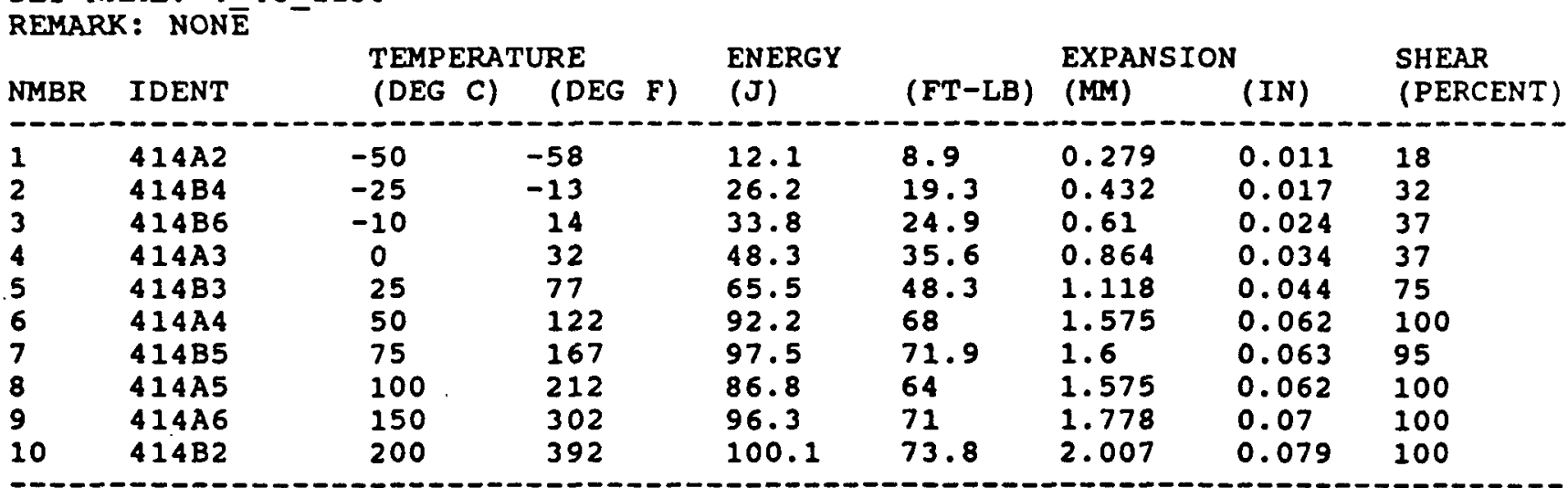

SET NAME: 451250

\begin{tabular}{|c|c|c|c|c|c|c|c|c|}
\hline NMBR & IDENT & $\begin{array}{l}\text { TEMP } \\
\text { (DEG }\end{array}$ & $\begin{array}{l}\text { URE } \\
\text { (DEG F) }\end{array}$ & $\begin{array}{l}\text { ENERGY } \\
\text { (J) }\end{array}$ & $(F T-L B)$ & $\begin{array}{l}\text { EXPANSION } \\
\text { (MM) }\end{array}$ & (IN) & $\begin{array}{l}\text { SHEAR } \\
\text { (PERCENT) }\end{array}$ \\
\hline $\begin{array}{l}1 \\
2 \\
3 \\
4 \\
5 \\
6 \\
7 \\
8 \\
9 \\
10\end{array}$ & $\begin{array}{l}421 A 2 \\
421 B 5 \\
421 A 3 \\
421 B 6 \\
421 B 3 \\
421 A 4 \\
421 B 4 \\
421 A 5 \\
421 A 6 \\
421 B 2\end{array}$ & $\begin{array}{l}-50 \\
-25 \\
0 \\
10 \\
25 \\
50 \\
75 \\
100 \\
150 \\
200\end{array}$ & $\begin{array}{l}-58 \\
-13 \\
32 \\
50 \\
77 \\
122 \\
167 \\
212 \\
302 \\
392\end{array}$ & $\begin{array}{l}10.8 \\
27.7 \\
50.8 \\
55.6 \\
77.3 \\
70.6 \\
91.4 \\
97.3 \\
97.8 \\
97.3\end{array}$ & $\begin{array}{l}8 \\
20.4 \\
37.5 \\
41 \\
57 \\
52.1 \\
67.4 \\
71.8 \\
72.1 \\
71.8\end{array}$ & $\begin{array}{l}0.203 \\
0.533 \\
0.864 \\
1.016 \\
1.422 \\
1.372 \\
1.6 \\
1.651 \\
1.676 \\
1.702\end{array}$ & $\begin{array}{l}0.008 \\
0.021 \\
0.034 \\
0.04 \\
0.056 \\
0.054 \\
0.063 \\
0.065 \\
0.066 \\
0.067\end{array}$ & $\begin{array}{l}20 \\
39 \\
58 \\
65 \\
90 \\
94 \\
99 \\
100 \\
100 \\
100\end{array}$ \\
\hline
\end{tabular}


Table C4. Continued

SOURCE: ANALYSIS SET

ANALYSIS SETS

$$
\text { 4_10_1250 4_20_1250 4_40_1250 }
$$

SET NAME: 4 10_1250

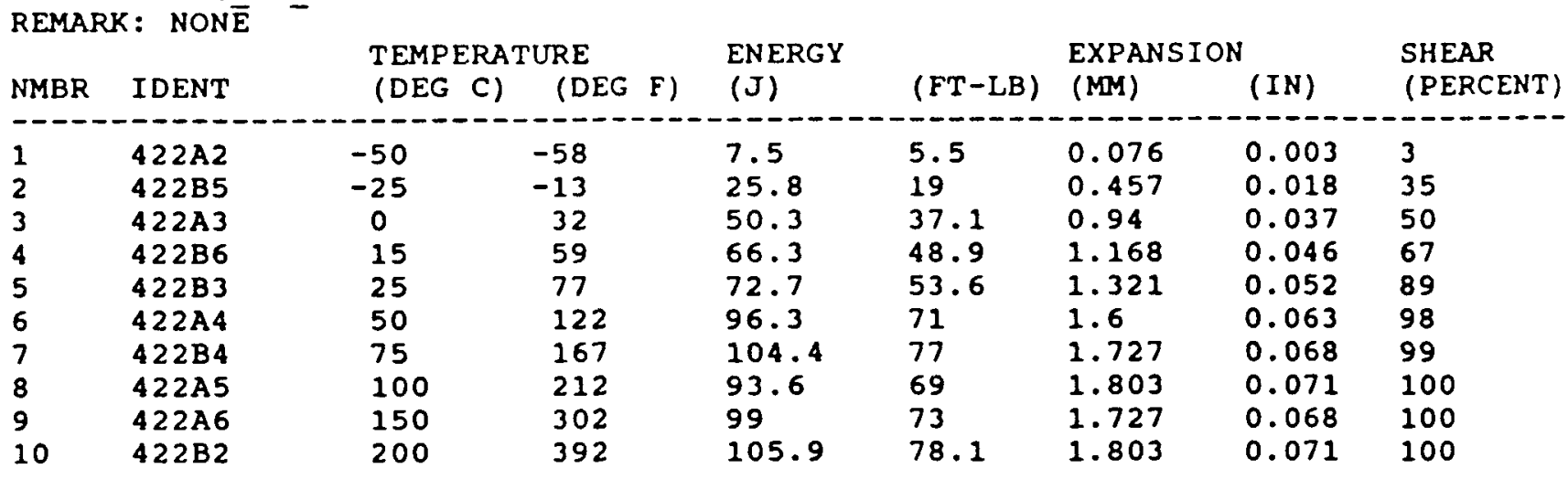

SET NAME: $4 \quad 20 \quad 1250$

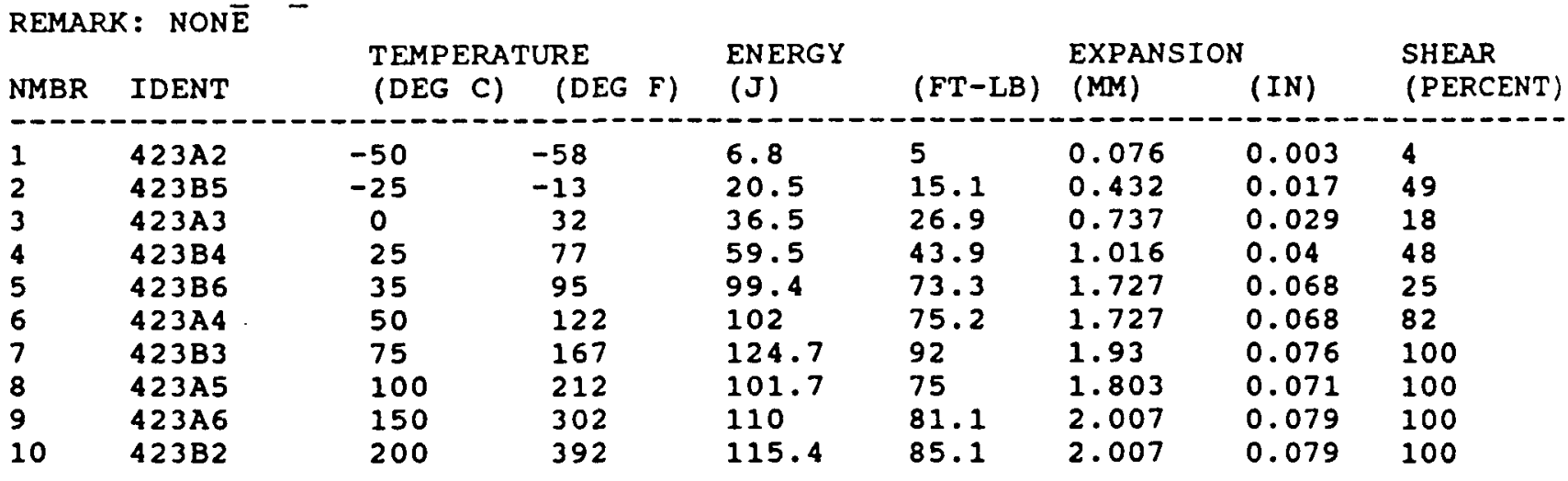

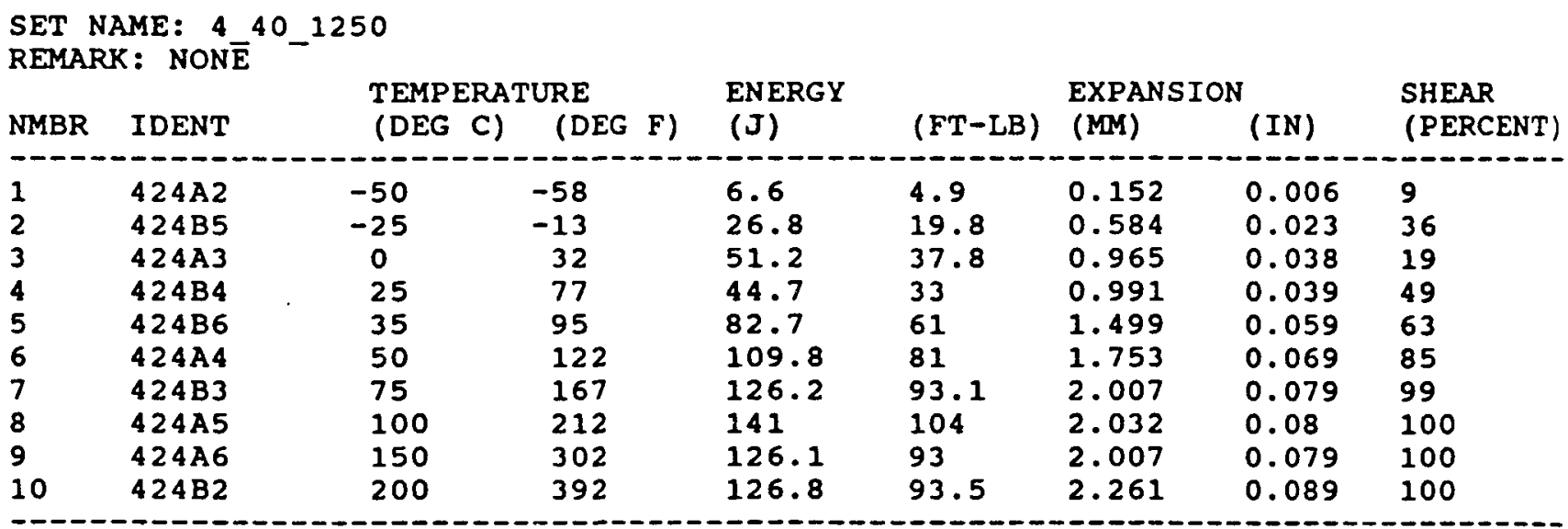


Table C4. Continued

SOURCE: ANALYSIS SET

ANALYSIS SETS

$$
\text { 4_5_1350 4_10_1350 4_20_1350 }
$$

SET NAME: 4_5_1350

REMARK : NON $\bar{E}$

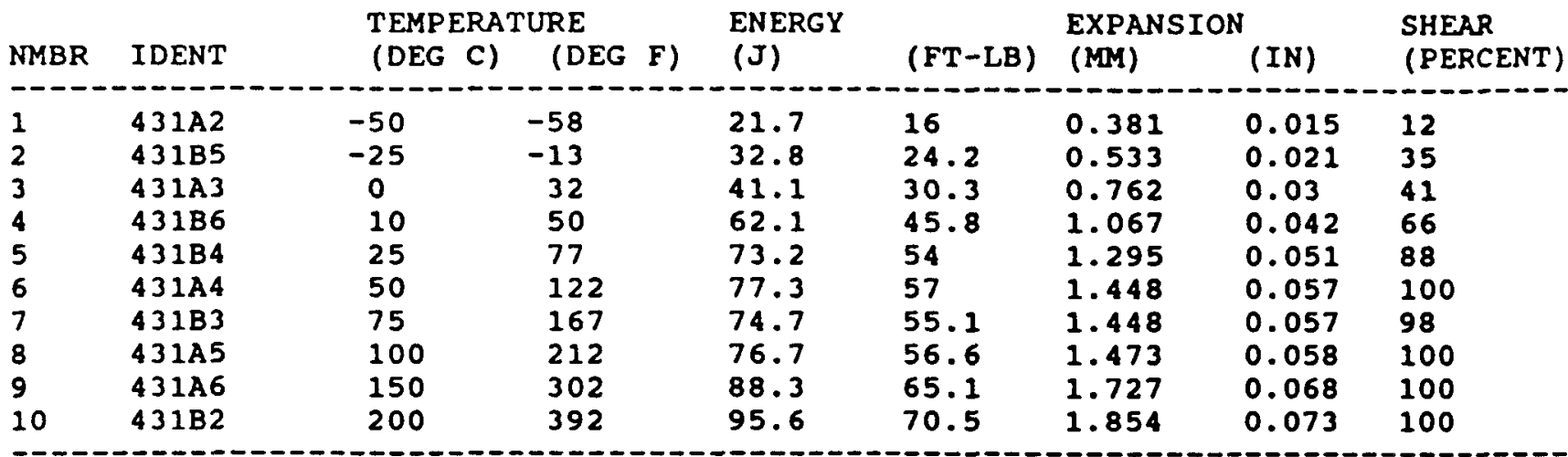

SET NAME: $4 \quad 10 \quad 1350$

REMARK: NON $\bar{E}$

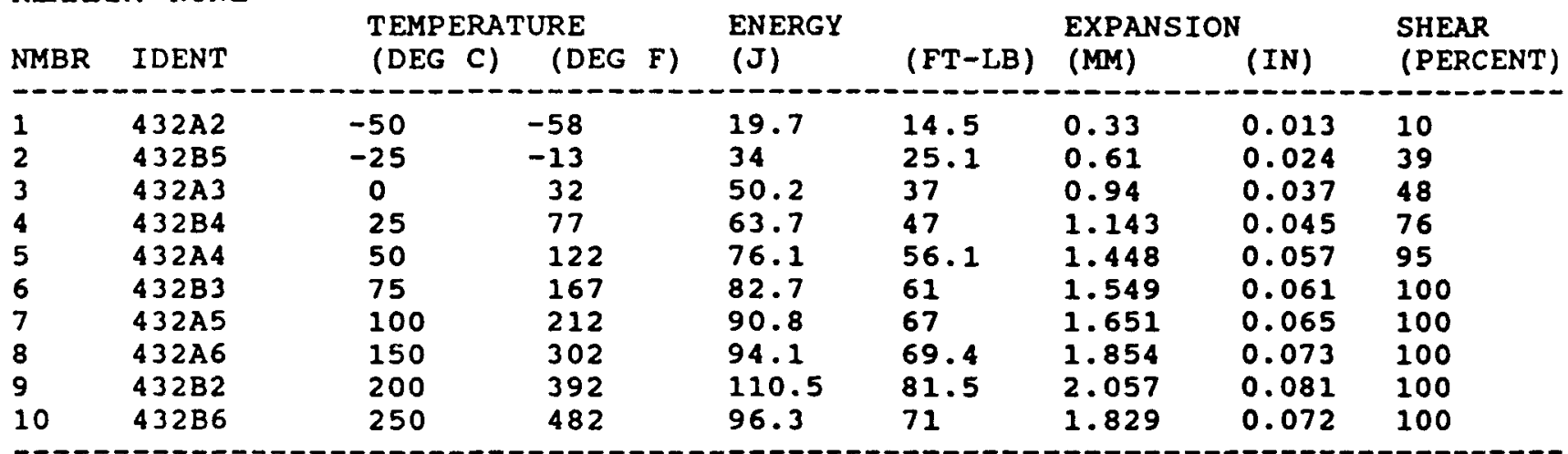

SET NAME: 4_20_1350

REMARK: NON $\bar{E}$

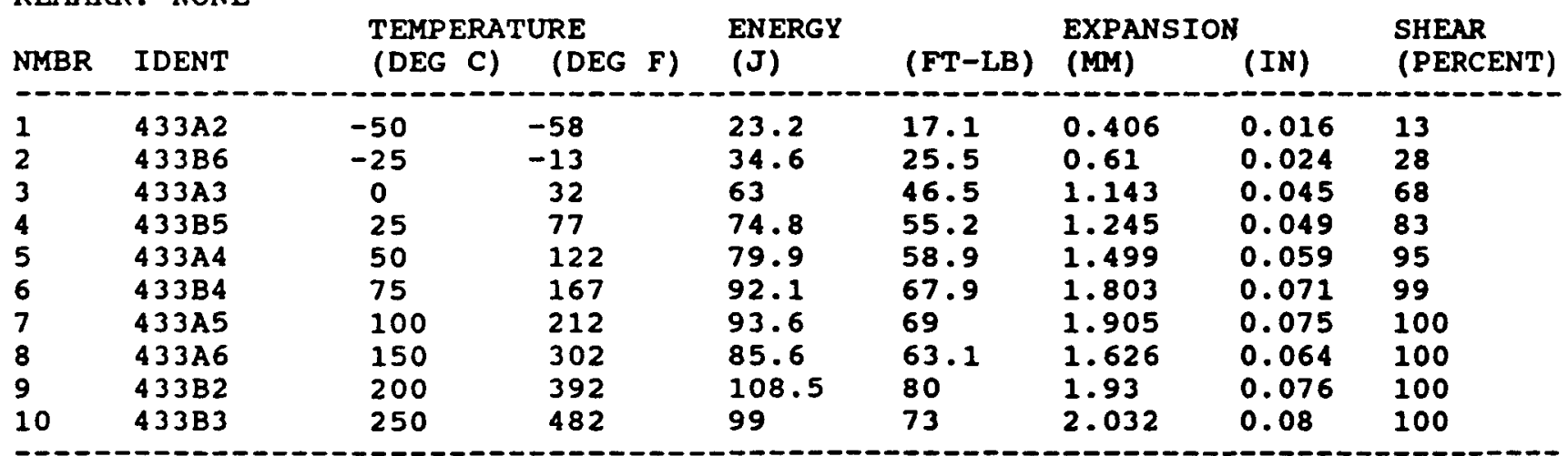


Table C4. Continued

SOURCE: ANALYSIS SET

ANALYSIS SETS

4_20_1550 4_5_1450

SET NAME: 4_20_1550

REMARK: NON $\bar{E}$

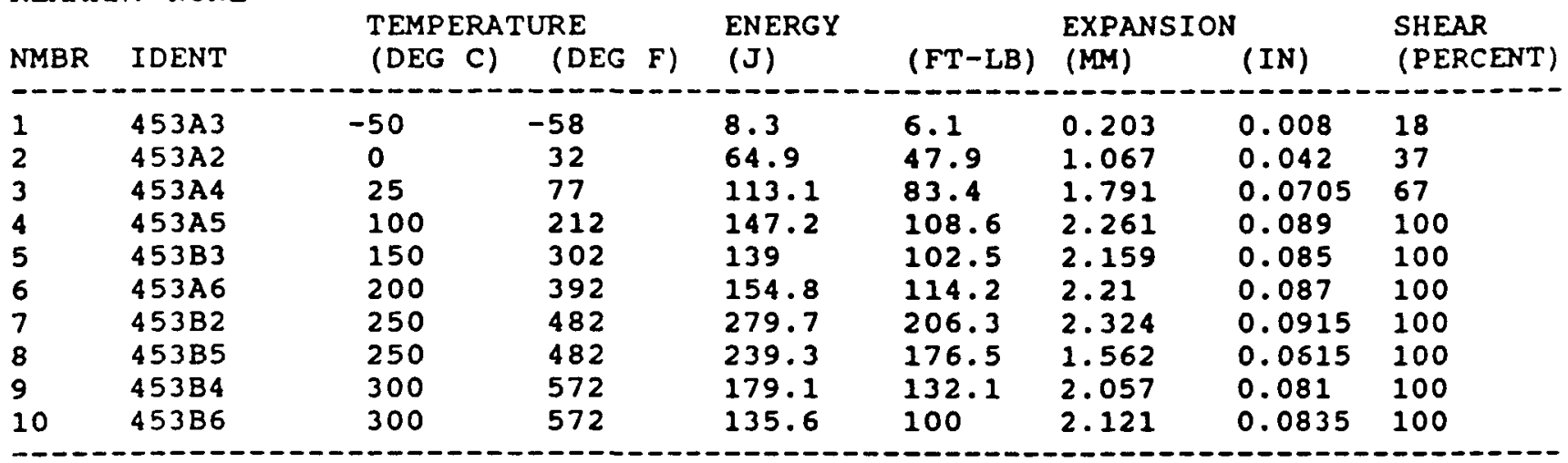

SET NAME: 4 5_1450

REMARK: NON $\bar{E}$

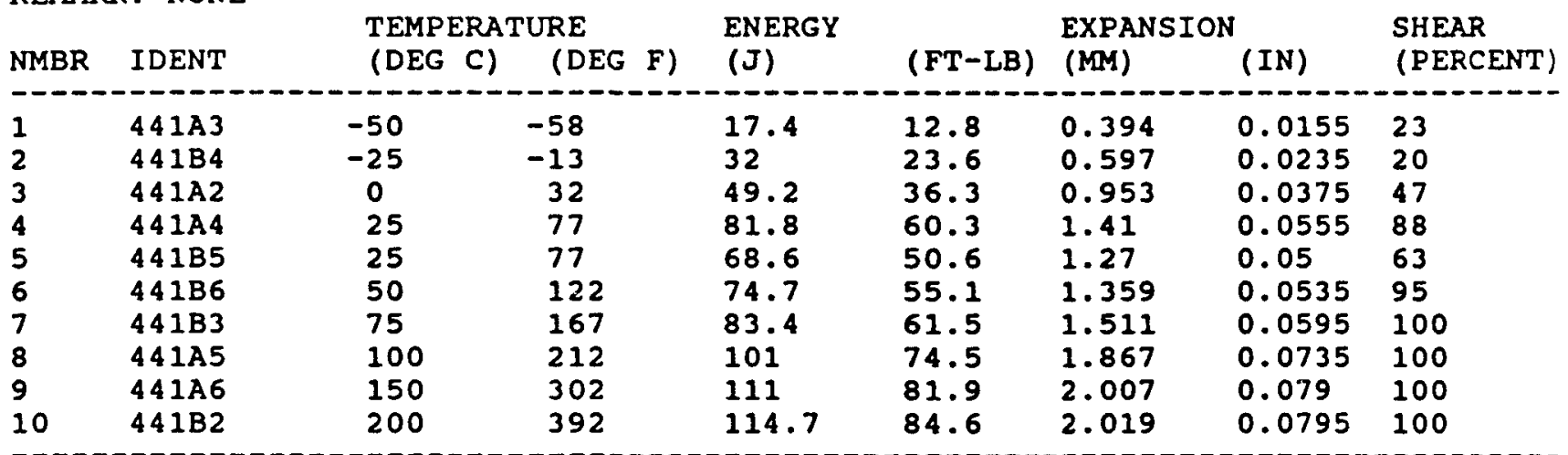


SOURCE: ANALYSIS SET

ANALYSIS SETS

$$
\text { 4_40_1450 4_5_1550 4_10_1550 }
$$

SET NAME: 4_40_1450

REMARK: NONE

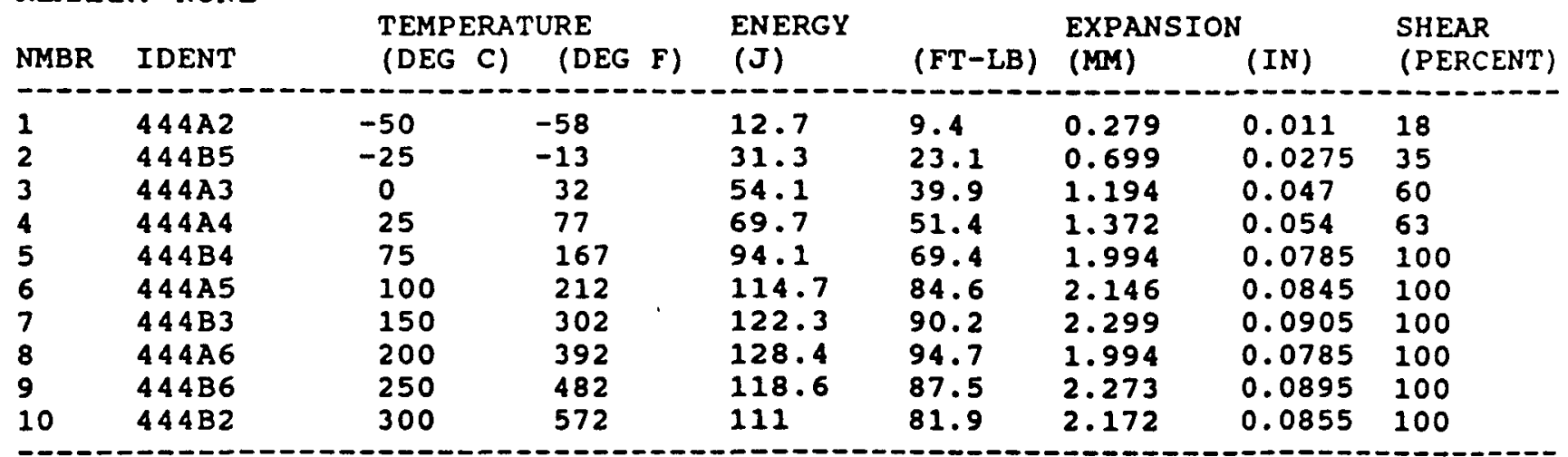

SET NAME: 4_5_1550

REMARK: NON $\overline{\mathrm{E}}$

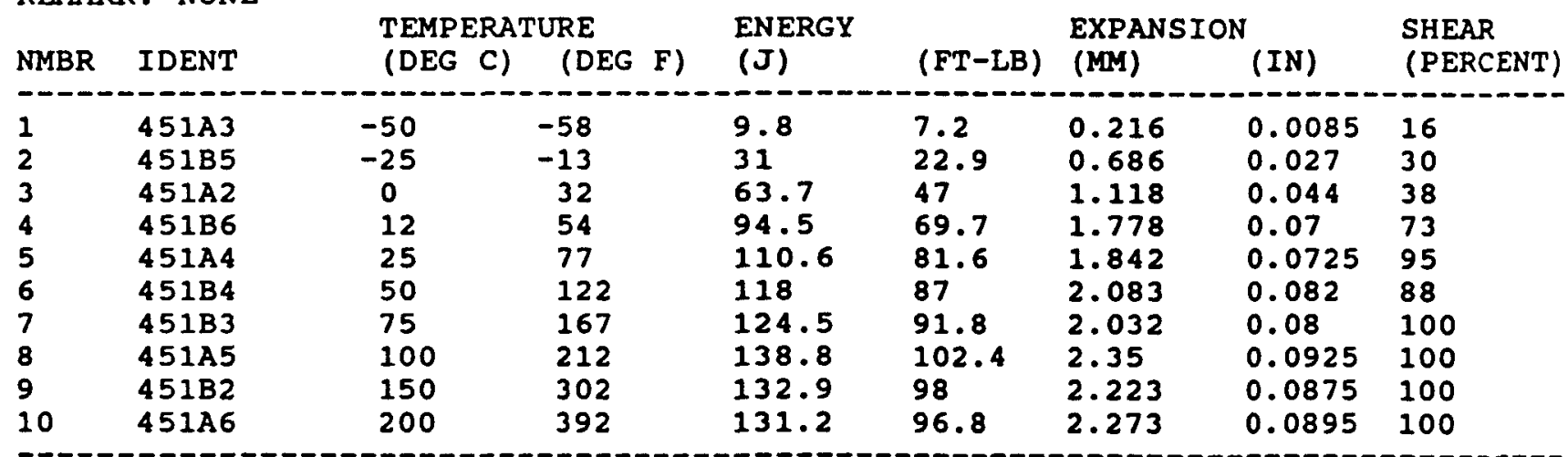

SET NAME: 4 10_1550

REMARK: NON $\bar{E}$

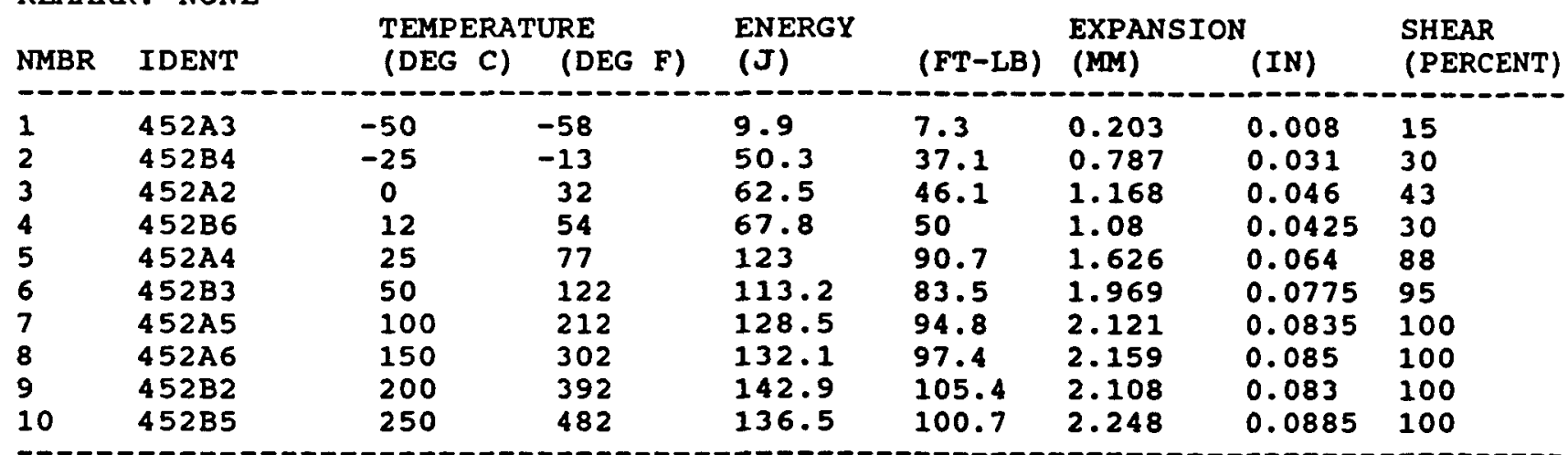




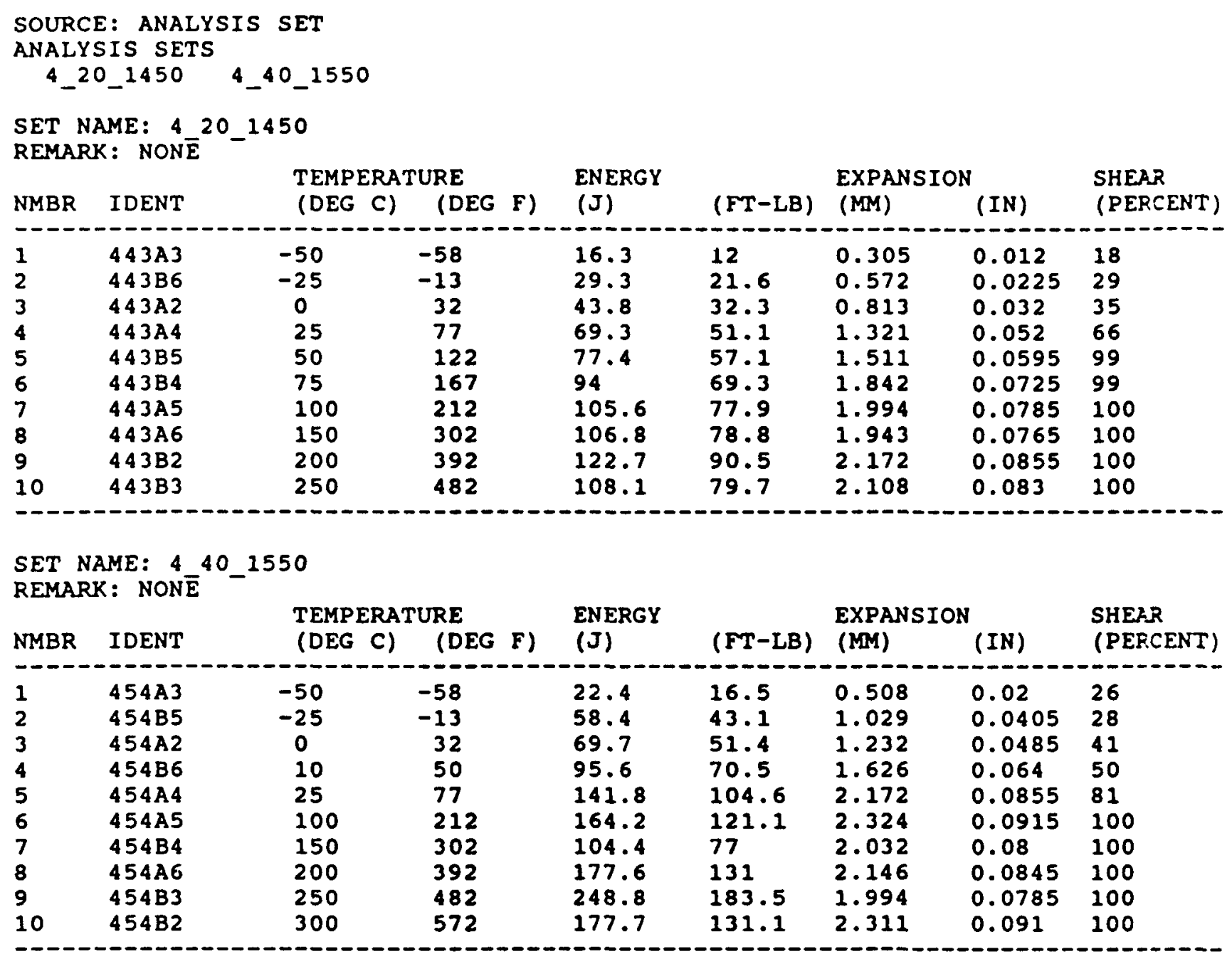


Table C4. Continued

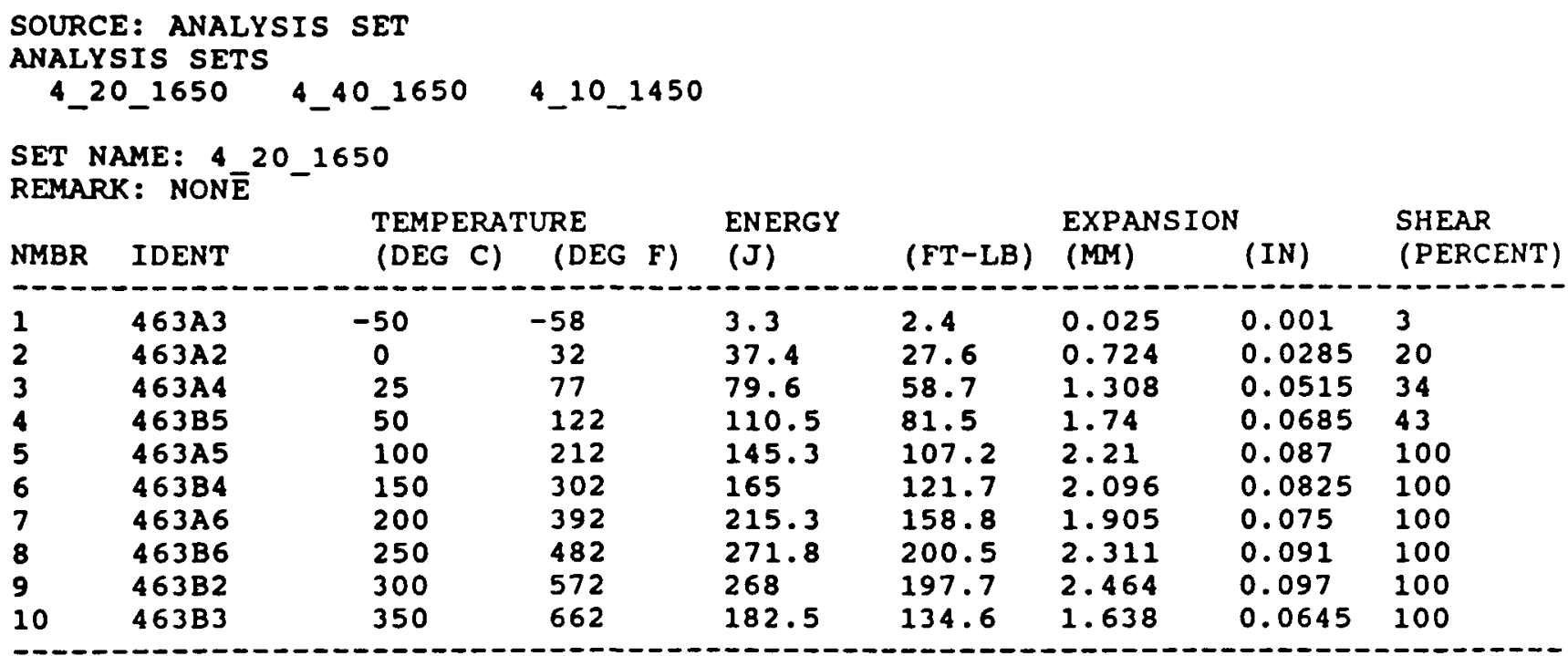

SET NAME: 4_40_1650

REMARK: NON $\bar{E}$

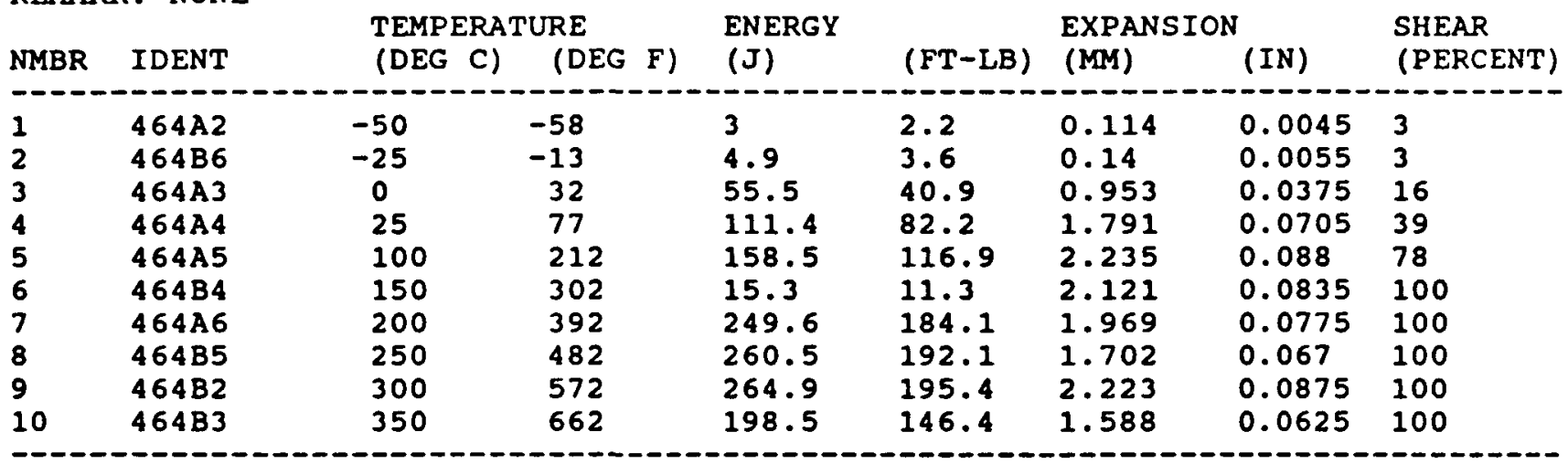

SET NAME: 4_10_1450

REMARK: NON $\bar{E}$

\begin{tabular}{|c|c|c|c|c|c|c|c|c|}
\hline NMBR & IDENT & $\begin{array}{l}\text { TEMPERAT } \\
\text { (DEG C) }\end{array}$ & $\begin{array}{l}\text { rURE } \\
\text { (DEG F) }\end{array}$ & $\begin{array}{l}\text { ENERGY } \\
\text { (J) }\end{array}$ & $(F T-L B)$ & $\begin{array}{l}\text { EXPANSION } \\
\text { (MM) }\end{array}$ & (IN) & $\begin{array}{l}\text { SHEAR } \\
\text { (PERCENT) }\end{array}$ \\
\hline $\begin{array}{l}1 \\
2 \\
3 \\
4 \\
5 \\
6 \\
7 \\
8 \\
9 \\
10\end{array}$ & $\begin{array}{l}442 A 4 \\
442 A 2 \\
442 A 3 \\
442 B 4 \\
442 A 5 \\
442 A 6 \\
442 B 2 \\
442 B 3 \\
442 B 5 \\
442 B 6\end{array}$ & $\begin{array}{l}-50 \\
0 \\
25 \\
75 \\
100 \\
150 \\
200 \\
250 \\
250 \\
300\end{array}$ & $\begin{array}{l}-58 \\
32 \\
77 \\
167 \\
212 \\
302 \\
392 \\
482 \\
482 \\
572\end{array}$ & $\begin{array}{l}25.6 \\
39 \\
72.7 \\
83.8 \\
89.5 \\
108.6 \\
114.3 \\
85.8 \\
104.5 \\
99.1\end{array}$ & $\begin{array}{l}18.9 \\
28.8 \\
53.6 \\
61.8 \\
66 \\
80.1 \\
84.3 \\
63.3 \\
77.1 \\
73.1\end{array}$ & $\begin{array}{l}0.495 \\
0.8 \\
1.384 \\
1.524 \\
1.702 \\
1.93 \\
1.918 \\
1.676 \\
1.956 \\
1.969\end{array}$ & $\begin{array}{l}0.0195 \\
0.0315 \\
0.0545 \\
0.06 \\
0.067 \\
0.076 \\
0.0755 \\
0.066 \\
0.077 \\
0.0775\end{array}$ & $\begin{array}{l}3 \\
37 \\
74 \\
100 \\
100 \\
100 \\
100 \\
100 \\
100 \\
100\end{array}$ \\
\hline
\end{tabular}


Table C4. Continued

SOURCE: ANALYSIS SET

ANALYSIS SETS

$$
\text { 4_40_1350 4_5_1650 4_10_1650 }
$$

SET NAME: 4 40_1350

REMARK : NON $\bar{E}$

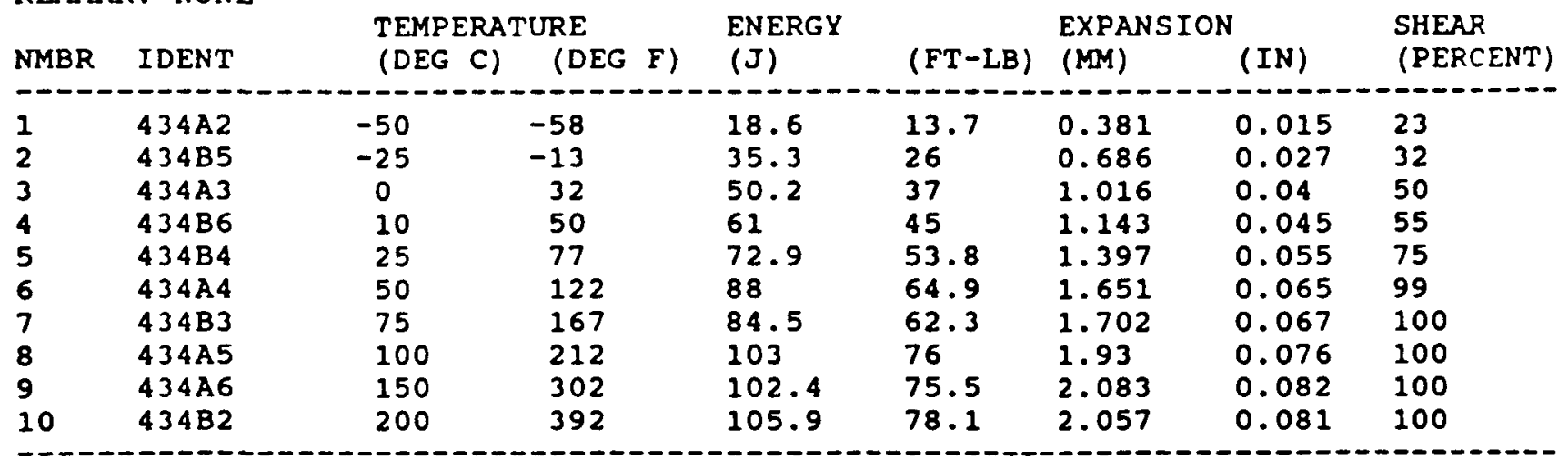

SET NAME: $4 \quad 5 \quad 1650$

REMARK: NONE

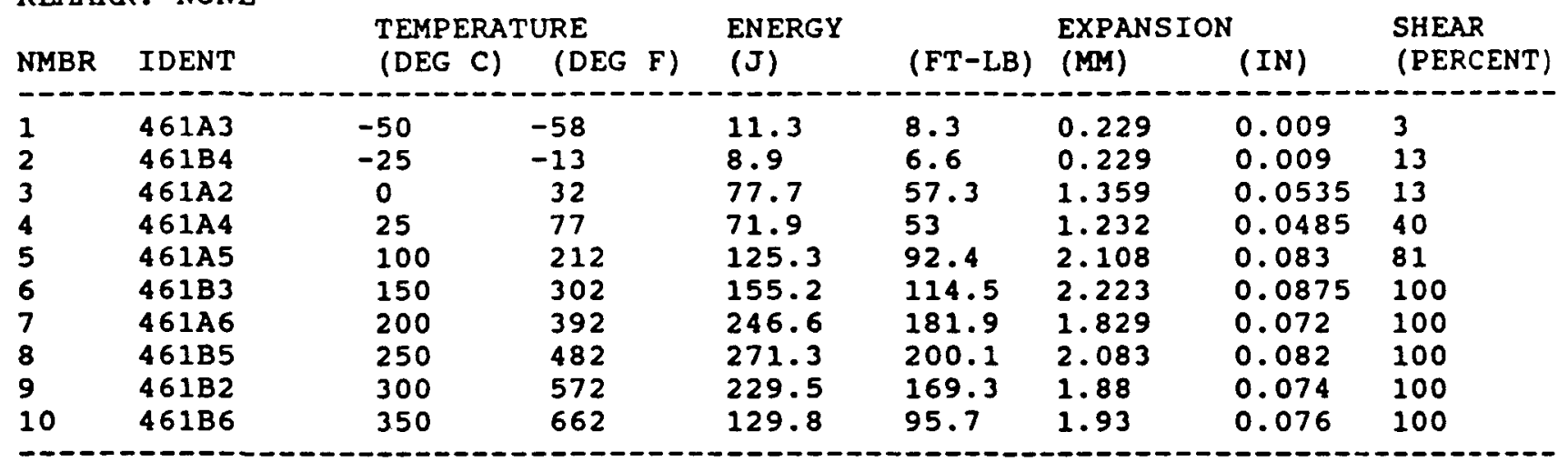

SET NAME: 4_10_1650

REMARK: NON $\overline{\mathrm{E}}$

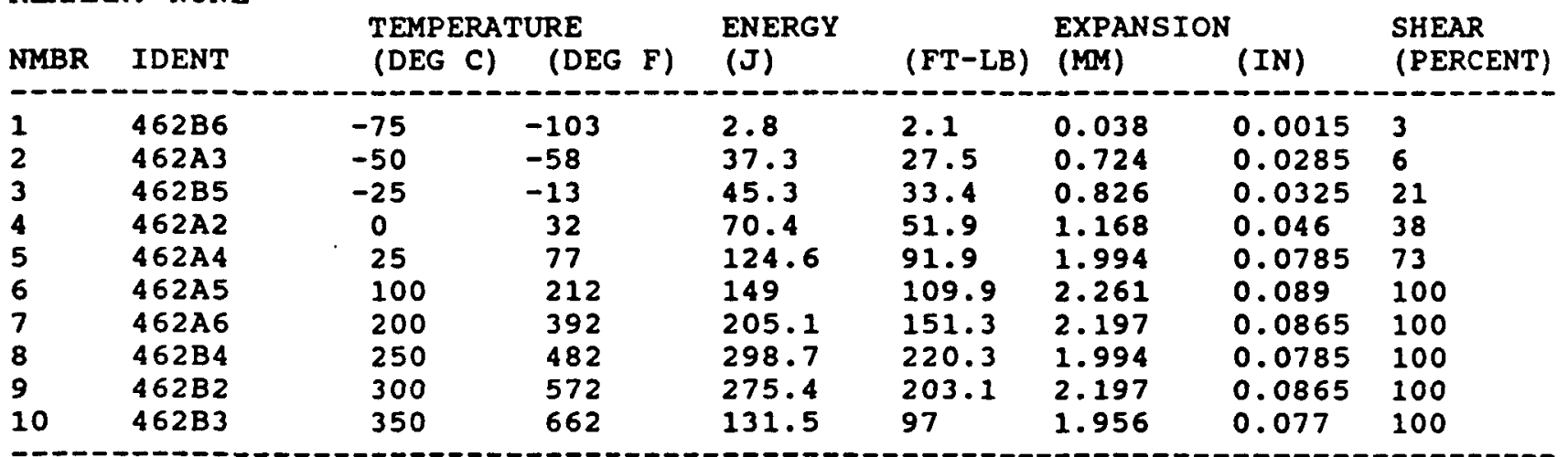


NUREG/CR-5972

ORNL/TM-12280

R5

\section{INTERNAL DISTRIBUTION}

1. D. J. Alexander

2. E. E. Bloom

3. C. R. Brinkman

4. D. A. Casada

5. W. R. Conwin

6. D. F. Craig

7. S. A. David

8-12. G. M. Goodwin

13. F. M. Haggag

14. H. W. Hayden, Jr.

15. S. K. Iskander

16. D. E. McCabe

17. J. G. Merkle

18. S. E. Moore
19-28. R. K. Nanstad

29. W. E. Pennell

30. C. E. Pugh

31. V. K. Sikka

32. G. M. Slaughter

33. R. L. Swain

34. R. W. Swindeman

35. ORNL Patent Section

36. Central Research Library

37. Document Reference Section

38-39. Laboratory Records Department

40. Laboratory Records (RC)

41-43. M\&C Records Office

\section{EXTERNAL DISTRIBUTION}

44-47. M. J. Swindeman, 125 Amanda Drive, Oak Ridge, TN 37830

48. R. G. Berggren, 2021 Woodrow Dr., Knoxville, TN 37918

49. EG\&G IDAHO, INC., P.O. Box 1625, Idaho Falls, ID 83415-2406

V. Shah

50. ELECTRIC POWER RESEARCH INSTITUTE, P.O. Box 10412, Palo Alto, CA 94303

T. J. Griesbach

51. GROVE ENGINEERING, Suite 218, 9040 Executive Park Drive, Knoxville,

TN 37923

W. A. Pavinich 
52-58. NRC, RES/Division of Engineering, Washington, DC 20555
A. Hiser (MS NS 217C)
S. N. Malik (MS NS 217C)
M. E. Mayfield (MS NS 217C)
C. Z. Serpan (MS NS 217C)
L. C. Shao (MS NLS 007)
A. Taboada (MS NS 217C)
M. Vagins (MS NS 217B)

59-61. NRC, NRR/Division of Engineering Technology, MS 7D4, Washington, DC 20555
B. J. Elliot
J. R. Strosnider
K. R. Wichman

62. NRC, RES/Division of Safety Issue Resolution, MS NLS 302, Washington, DC 20555

R. E. Johnson

63. G. D. Whitman, 931 West Outer Drive, Oak Ridge, TN 37830

64. DOE OAK RIDGE FIELD OFFICE, P.O. Box 2001, Oak Ridge, TN 37831-6269 Office of Deputy Assistant Manager for Energy Research and Development

65-66. DOE, OFFICE OF SCIENTIFIC AND TECHNICALINFORMATION, P.O. Box 62, Oak Ridge, TN 37831 